\title{
Cretaceous and Early Tertiary
}

\section{Depositional and Tectonic History}

of the Livingston Area,

\section{Southwestern Montana}

By ALBERT E. ROBERTS

GEOLOGY OF THE LIVINGSTON AREA, SOUTHWESTERN MONTANA

GEOLOGICAL SURVEY PROFESIONAL PAPER 526-C

A study of the character of the sedimentary rocks-their texture, variation in composition, age assignments, regional correlation, and tectonic implications

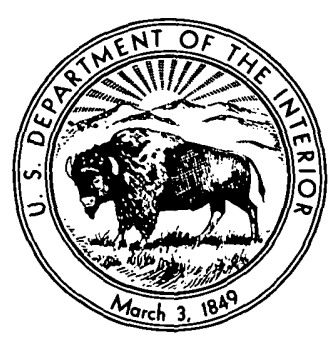




\section{UNITED STATES DEPARTMENT OF THE INTERIOR \\ ROGERS G. B. MORTON, Secretary \\ GEOLOGIGAL SURVEY \\ V. E. McKelvey, Director}

For sale by the Superintendent of Documents, U.S. Government Printing Office

Washington, D.C. 20402. (paper cover)

Stock Number 2401-0201 


\section{CON TENTS}

Abstract...

Introduction

Location................

Acknowledgments . . . .

Geologic setting . . . . . . . . .

Stratigraphic summary

Laramide deformation..............

Cretaceous System...

Lower Cretaceous Series.

Kootenai Formation

Thermopolis Shale.

Mowry Shale

Upper Cretaceous Series............

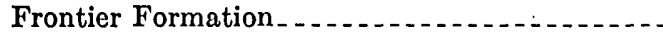

Cody Shale.................

Telegraph Creek Formation...

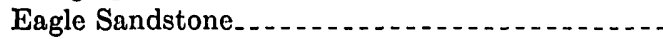

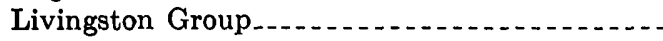

Cokedale Formation. . . .

Miner Creek Formation

Billman Creek Formation................

Hoppers Formation ........................

Cretaceous and Tertiary Systems.

Upper Cretaceous and Paleocene Series..........

Fort Union Formation.............

Heavy-mineral suites in the Fort Union Formation

and Livingston Group........

Eocene Series. . .

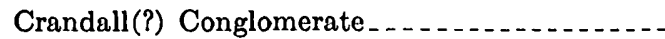

Cathedral Cliffs(?) Formation. ...........

Golmeyer Creek Volcanics. . . . . . . . . . . . .

Hyalite Peak Volcanics.....................

Selected stratigraphic sections

Methods of study and definitions of terms.

\begin{tabular}{|c|c|c|}
\hline $\begin{array}{c}\text { Page } \\
\text { P1 }\end{array}$ & Selected stratigraphic sections-Continued & Page \\
\hline C1 & Kootenai Formation & C59 \\
\hline 2 & Section $11 \ldots$ & 59 \\
\hline 2 & Section 2 & \\
\hline 2 & Section 3 & \\
\hline 2 & Thermopolis Shale & \\
\hline 2 & Section 4 & \\
\hline 9 & Section 5 & \\
\hline 12 & Section 6 & \\
\hline 12 & Mowry Shale & \\
\hline 12 & Section 7 & \\
\hline 16 & Section 8 & \\
\hline 19 & Section 9 & \\
\hline 24 & Frontier Formation & \\
\hline 24 & Section 10 & \\
\hline 27 & - & \\
\hline 29 & 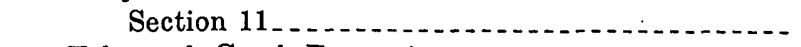 & \\
\hline 30 & Telegraph Creek Formation & \\
\hline 34 & Section 12 & \\
\hline 42 & 13 & \\
\hline 46 & Eagle Sandstone & \\
\hline 48 & Section 14 & \\
\hline 50 & Section 15 & \\
\hline 51 & Cokedale Formation & \\
\hline 51 & Section 16 & \\
\hline 51 & Miner Creek Formation & \\
\hline & 17 & \\
\hline 55 & Billman Creek Formation & \\
\hline 55 & Section 18 & \\
\hline 55 & Hoppers Formation & \\
\hline 56 & Section 19 & \\
\hline 57 & Fort Union Formation & \\
\hline 57 & Section 20 & \\
\hline 58 & eferences cited & \\
\hline 58 & dex & \\
\hline
\end{tabular}

\section{ILLUSTRATIONS}

[Plates are in pocket]

Plate 1. Geologic map of the area west of Livingston, Gallatin and Park Counties, Mont.

2. Stratigraphic columns of the Paleozoic and Jurassic rocks, Kootenai Formation, Thermopolis Shale, Mowry Shale, Frontier Formation, Cody Shale, Telegraph Creek Formation, Eagle Sandstone, Livingston Group, and Fort Union Formation exposed in the area west of Livingston, Gallatin and Park Counties.

3. Tectonic map of the Crazy Mountains basin and adjacent areas of southwestern Montana.

Fiaure 1. Index maps, showing location of area discussed west of Livingston, Gallatin and Park Counties, Mont..........-

2. Chart showing correlation and stratigraphic relations of Cretaceous rocks of the Livingston area with other areas in Montana and Wyoming 
Frgore 3-12. Photographs showing-

3. Exposed Precambrian core of the recumbent Canyon Mountain anticline with the Suce Creek thrust fault along its base.

4. Andesitic dikes cutting mudstones and sandstones of the Billman Creek Formation

5. Reference section of the Kootenai Formation on the west flank of Chestnut Mountain anticline...

6. Repeated reverse graded bedding in the Pryor Conglomerate Member of the Kootenai Formation.-

7. Lower sandstone member of the Thermopolis Shale

8. Fretwork on a cliff of crossbedded sandstone

8. Prominent 10-foot-thick sandstone unit 32 fee Member of the Frontier Formation.

10. Boulder River Sandstone Member of the Frontier Formation

11. Thin-bedded glauconitic very fine grained sandstone of the Eldridge Creek Member of the Cody Shale.

12. Telegraph Creek Formation immediately east of Livingston, Mont., on east bank of the Yellowstone River.

13. Stratigraphic reference section of the Eagle Sandstone at Cokedale, Mont

14. Map showing distribution of the Livingston Group in relation to the Crazy Mountains depositional basin and the Elkhorn Mountains source area in southwestern Montana:

15. Index map showing locations of measured units for the type Livingston Group and Fort Union Formation near Livingston, Mont.

16-21. Photographs showing-

16. Type Cokedale Formation near the former coal-mining town of Cokedale, Mont

17. Overturned sandstone and siltstone beds of the Miner Creek Formation in roadcut at

18. Massive mudstones interbedded with sandstones and claystones typical of the Billman Creek Formation

19. Massive to crossbedded andesitic sandstone 95 feet above the base of the Billman Creek Formation. 20. Maximum thickness of the Fort Union Formation near the axis of the Fleshman Creek syncline....

21. Basal part of the upper conglomeratic sandstone member of the Fort Union Formation at Grassy Mountain.

22. Chart showing correlation and stratigraphic relations of part of the lower Tertiary rocks of the Livingston area, Montana, with rocks of other areas in Montana and Wyoming 23-25. Photographs showing-

23. Sedimentary and volcanic rocks of Wasatchian and Bridgerian ages overlying the Eagle Sandstone of Late Cretaceous age at the northern end of the Gallatin Range.

24. Crandall(?) Conglomerate exposed on north side of Maxey Ridge .

25. Volcanic agglomerate or lahar in the Hyalite Peak Volcanics that overlie the Cathedral Cliffs(?) Formation at Maxey Ridge

C11

12

13

14

17

18

25

25

28

30

33

35

44

45

46

49

49

51

52

53

56

57

58

\section{T AB LES}

Table 1. Grain-size distribution and heavy-mineral content in sandstones of the Thermopolis Shale, Frontier Formation, Cody Shale, Telegraph Creek Formation, and Eagle Sandstone near Livingston, Mont ..........

2. Checklist of plant and miscellaneous microfossils from the Thermopolis and lower Mowry Shales near Livingston, Mont

3. Checklist of plant and miscellaneous microfossils from the Skull Creek Shale and Mowry Shale reference section near Buffalo, Wyo

4. Checklist of plant and miscellaneous microfossils from the type Livingston Group and the Fort Union Formation near Livingston, Mont.

5. Chemical (rapid rock) analyses of very fine grained clastic rocks from the Livingston Group and of comparative samples from the Telegraph Creek Formation and Eagle Sandstone at Cokedale, Mont. .........

6. Heavy-mineral content and grain-size distribution in sandstones in the type Livingston Group and Fort Union Formation, Cokedale, Mont.
Page 


\title{
CRETACEOUS AND EARLY TERTIARY DEPOSITIONAL AND TECTONIC HISTORY OF THE LIVINGSTON AREA, SOUTHWESTERN MONTANA
}

\author{
By Albert E. Roberts
}

\begin{abstract}
Cretaceous and lower Tertiary rocks exposed near Livingston, southwestern Montana, form a marine and continental sequence of sedimentary and volcanic rocks more than 20,000 feet thick. Correlation of these rocks with those in other areas of Montana and Wyoming is based on recent studies of structure, facies relations, and paleontology of the Livingston sequence. The Lower Cretaceous Series is 1,250 feet thick and includes the Kootenai Formation, the Thermopolis Shale, and the Mowry Shale. The Upper Cretaceous Series is 10,830 feet thick and is correlated with or consists of the Frontier Formation, Cody Shale, Telegraph Creek Formation, Eagle Sandstone, Cokedale Formation, Miner Creek Formation, Billman Creek Formation, Hoppers Formation, and the basal 980 feet of the Fort Union Formation. The Paleocene Series consists of the upper 5,635 feet of the Fort Union Formation. The Eocene Series is more than 1,700 feet thick and consists of the Crandall(?) Conglomerate, Cathedral Cliffs(?) Formation, and the Golmeyer Creek and Hyalite Peak Volcanics.

The Cretaceous and Tertiary tectonic history of the Livingston area is complex. Uplift to the west at the close of the Jurassic initiated the continental deposition of the Kootenai Formation.

From the end of Kootenai time through Eagle time, epicontinental Cretaceous seas transgressed and regressed across the relatively stable Livingston area. Late in the Coniacian or early Santonian Stage of Late Cretaceous time, epeirogenic arching began in western Montana, and the Eagle sea regressed to the enst. Beds as old as the Lodgepole Limestone of Early Mississippian age were exposed by erosion. Periodic uplift and erosion were accompanied by the most extensive volcanism that has occurred in western Montana. Contemporaneously, the Livingston area was gradually warped downward as part of the Crazy Mountains basin, and more than 13,000 feet of sedimentary rock-derived predominantly from the western volcanic rockswas deposited as the Livingston Group and the Fort Union Formation. This continuous sequence of continental rocks grades laterally to the east and northeast beyond the Livingston area into finer grained marine and nonmarine units. Subsidence and deposition were greater in the western part of the basin than in the eastern part and were accelerated in both parts in late Campanian and Maestrichtian time.

During deposition of the Fort Union Formation, the borderland in the area now occupied by the northern part of the Gallatin Range and the Bridger Range continued to rise and thereby restricted the western limit of the Fort Union of Montana to the longitude of the Crazy Mountains basin. Sedimentary units of the Fort Union were folded, probably near the close of the Paleocene Epoch. Major thrusting then occurred in areas bordering the thickest deposits. South of Livingston the ancestral Gallatins, which formed the southwestern edge of the basin, were covered in early Eocene time by conglomeratic units equivalent to the Crandall Conglomerate and the Cathedral Cliffs Formation of northwestern Wyoming. None of these units extended northward into the basin. These Eocene deposits remain relatively undeformed in contrast to the underlying folded formations, a fact indicating that the last major period of folding for this area occurred near the end of Paleocene or the beginning of Eocene time. The conglomeratic units are overlain by Eocene volcanic rocks-generally flows, flow breccias, and mudflows-that correlate with the oldest volcanic units in the Yellowstone Park region.

Both the Livingston Group and the Fort Union Formation at Livingston vary rapidly in lithology, vertically and laterally; these rocks probably represent fluvial channel systems associated with extensive flood-plain deposits near sea level, judging by their similarities to deposits on present-day flood plains. The major source of these sediments was west of the Crazy Mountains basin; lesser amounts of sediment came from areas northwest and south of the basin. The character of the rocks at the base of the Fort Union differs markedly from that of rocks of the underlying Livingston Group. The conglomerates in the Livingston Group are composed almost entirely of volcanic rocks like those presently exposed in the Elkhorn Mountains of western Montana, whereas the conglomerates in the Fort Union contain igneous, metamorphic, and sedimentary rock fragments derived from rocks of Precambrian, Paleozoic, and Mesozoic age. This significant change in provenance suggests a closer source area for the Fort Union and one in which there were greater dissection and more vigorous erosion than for the earlier deposited Livingston Group.
\end{abstract}




\section{INTRODUCTION}

\section{LOCATION}

The area of this report, hereafter referred to as the Livingston area, is at the junction of the northern end of the Gallatin Range, the southern end of the Bridger Range, and the western end of the Beartooth Range in east-central Gallatin County and west-central Park County, southwestern Montana (fig. 1).

The Gallatin Range is bounded on the east by Paradise Valley, through which the Yellowstone River flows. The Gallatin River valley delimits the west edge of the range.

The Livingston area includes part of the southwestern edge of the Crazy Mountains basin. This basin is elongated northwest and is approximately 40 to 75 miles wide and 100 to 130 miles long. The Crazy Mountains basin is bordered by the Beartooth Range to the south, the Gallatin Range to the southwest, the Bridger Range to the west, the Big Belt and Little Belt Mountains to the north, and the Lake Basin fault zone and Pryor uplift and related structures to the east (see pl. 3). The sedimentary deposits of Cretaceous and Paleocene age in the southwest part of the Crazy Mountains basin, chiefly in the area between Bozeman and Livingston, Mont., are the principal subject of this report.

\section{ACKNOWLEDGMENTS}

W. A. Cobban, C. L. Gazin, E. B. Leopold, R. H. Tschudy, and D. W. Taylor identified fossils collected in the area. A citation as to the type of fossils and other data appears with their identification. A. L. Benson, J. S. Hollingsworth, and C. A. Sandberg assisted in measuring stratigraphic sections. Mechanical analyses and heavy-mineral separates were made by R. F. Gantnier. Clay-mineral identifications were made by L. G. Schultz. The writer has benefited from discussions about stratigraphic problems or paleontologic interpretations with numerous colleagues and is particularly indebted to W. A. Cobban, J. R. Gill, W. R. Keefer, M. R. Klepper, W. J. Mapel, L. W. McGrew, W. J. McMannis, B. A. L. Skipp, and H. W. Smedes.

\section{GEOLOGIC SETTING}

The distribution of outcropping rock units in the Livingston area, as shown on plate 1 , reflects a complex Cretaceous and early Tertiary history. The following "Stratigraphic Summary" and "Laramide Deformation" place the formations of this period into a historical framework for better understanding the depositional sequences and tectonic events.

\section{STRATIGRAPHIC SUMMARY}

The oldest rocks exposed in this area are Precambrian gneiss, granite, and schist in the cores of the major anticlines and in the uplifted blocks of the Beartooth, Bridger, and Gallatin Ranges. The overlying sedimentary rocks range in age from Middle Cambrian to Tertiary and are more than 20,000 feet thick (Roberts, 1964a-h). Only two systems, the Silurian and Triassic, are not represented. The Paleozoic rocks, more than 3,000 feet thick, are generally exposed along the axes of the major anticlines. Rocks of Jurassic age are 700 feet thick and form a prominent narrow belt along the flanks of anticlines. The stratigraphic sequence of the Jurassic and older formations is summarized on plate 2. Nearly 12,000 feet of Cretaceous rocks are also exposed along the flanks of anticlines, as well as in the troughs of intervening synclines. Lower Tertiary rocks include about 5,000 feet of Paleocene strata in the southwestern part of the Crazy Mountains basin and approximately 1,700 feet of volcanic and sedimentary rocks of Eocene age that cap ridges in the northern part of the Gallatin Range. A nearly complete cross section of the Paleozoic and Mesozoic formations is exposed in the eastern part of the area on walls of the lower canyon of the Yellowstone River just south of Livingston, Mont. (pl. 1).

Periodically, during Paleozoic and early Mesozoic time the Livingston area was part of a broad marine shelf that bordered the east side of the Cordilleran miogeosyncline, where predominantly carbonate rocks were deposited in shallow epicontinental seas. For approximately half of Paleozoic and early Mesozoic time, however, the area was above sea level and was subjected to subaerial erosion or was the site of deposition for thin layers of continental sedimentary rocks. For a résumé of the depositional and structural history of these rocks, the reader is referred to McMannis (1965).

In Late Jurassic time, the Ellis sea that had covered most of Montana withdrew northward into northern Canada. During the period of nonmarine deposition that followed, the Morrison Formation (Upper Jurassic) and Kootenai Formation (Lower Cretaceous) and their stratigraphic equivalents were deposited. Near the beginning of the late Albian of the Early Cretaceous, a northward transgressing Skull Creek (Thermopolis) sea covered most of Montana, and late in the Early Cretaceous a southward transgressing Mowry sea again covered most of Montana. During middle Albian through Campanian time, the western edge of the Cretaceous Interior basin of Montana was the site of several alternating westward transgressions and eastward regressions of the sea. Oscillations of the Cretaceous epicontinental sea that formed these stages probably 


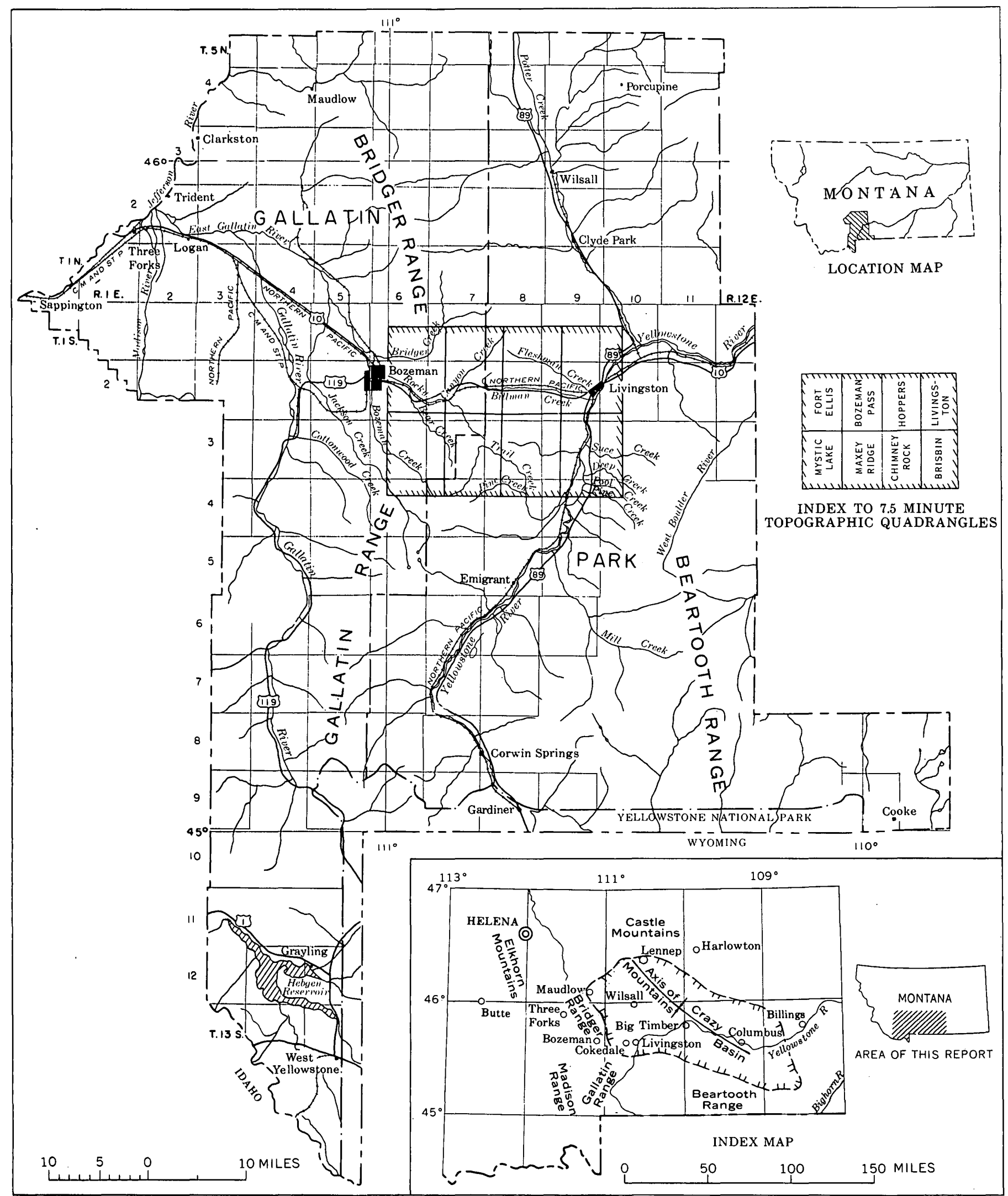

Fraure 1.-Index maps, showing location of area discussed that is west of Livingston, Mont., and in Gallatin and Park Counties. Hachured line on lower inset map shows approximate limit of Crazy Mountains basin. 
resulted from differential crustal movements. Regional studies of Upper Cretaceous shorelines by J. R. Gill and W. A. Cobban (oral commun., 1968) indicate that, while subsidence was taking place in one locality, uplift and erosion were taking place in another; thus transgression in one area was not necessarily accompanied by transgression in another. Rocks deposited during major Cretaceous regressions of the sea in southwestern Montana include the Frontier Formation, Eagle Sandstone, and parts of the Livingston Group and Fort Union Formation, or their stratigraphic equivalents. Prominent sandstone units, such as the lower and upper members of the Thermopolis Shale and the Eldridge Creek Member of the Cody Shale, represent near-shore marine deposition.

The Cretaceous System and Paleocene Series near Livingston, Mont., consist of sedimentary rocks that overlie the Morrison Formation of Late Jurassic age. These rocks were briefly described and correlated with Cretaceous and lower Tertiary rocks in other areas of Montana and Wyoming by Roberts (1965). This 17,715foot-thick sequence includes the Kootenai Formation, Thermopolis Shale, Mowry Shale, Frontier Formation, Cody Shale, Telegraph Creek Formation, Eagle Sandstone, Cokedale Formation, Miner Creek Formation, Billman Creek Formation, Hoppers Formation, and the Fort Union Formation. Columnar sections illustrating the stratigraphic sequence of these formations are presented on plate 2 . The correlation and stratigraphic relations of the Cretaceous rocks of the Livingston area, Montana, with other areas in Montana and Wyoming are shown in figure 2. The Paleocene Series consists of sedimentary rocks of the middle and upper parts of the Fort Union Formation.

Volcanism occurred intermittently throughout Cretaceous and early Tertiary time; volcanic ash or other volcanic detritus are major constituents of the Kootenai Formation, Mowry Shale, Livingston Group, Fort Union Formation, Cathedral Cliffs (?) Formation, and Golmeyer Creek and Hyalite Peak Volcanics. Volcanic ash, represented by bentonite, is also present in the Kootenai, Thermopolis, Mowry, Frontier, and Cody Formations and in the Livingston Group.

The Jurassic Period closed with uplift west of the Livingston area, probably near central or southeastern Idaho. Coarse clastic materials shed from this western upland were repeatedly reworked and formed a massive chert-pebble conglomerate that marks the beginning of Cretaceous deposition; this is the Pryor Conglomerate Member of the Kootenai Formation. During the remainder of Kootenai time, sandstone, limestone, and very fine grained clastic sediments accumulated on extensive alluvial plains and in a large fresh-water lake or lakes. The Kootenai Formation at Livingston is probably equivalent to the Lakota Formation of northeastern Wyoming and to the Cloverly Formation of central Wyoming (fig. 2).

The Thermopolis Shale unconformably overlies the Kootenai Formation and represents deposits of the initial transgression of the Cretaceous sea. The Thermopolis is subdivided into a lower sandstone member, a middle shale member, and an upper sandstone member. Exposures are generally poor; otherwise these members could be mapped as individual units. The Thermopolis Shale is dominantly soft, dark-gray to black, marine shale overlain and underlain by prominent sandstone ridges or ledges formed by the lower and upper members.

The lower sandstone member rests unconformably on the Kootenai Formation, commonly filling topographic depressions on the underlying erosion surface. The hiatus between the Kootenai Formation and the lower sandstone member of the Thermopolis Shale is presumed to be short inasmuch as the index fossil Protelliptio douglassi occurs immediately above and below the widespread disconformity separating the two formations (W. A. Cobban, oral commun., 1963). The lower member is a clean quartzose sandstone that in local areas of intense folding is a quartzite; it was probably deposited in a transgressive near-shore marine environment. The lower sandstone member of the Thermopolis Shale is approximately equivalent to the "Rusty beds" and Greybull Sandstone Member of the Thermopolis of northcentral Wyoming, the Fall River Formation of the Black Hills area of northeastern Wyoming, and the Flood Member of the Blackleaf Formation of northwestern Montana (fig. 2).

The conformably overlying middle shale member is a black marine shale that contains numerous thin beds of siltstone and very fine grained sandstone. The middle shale member contains an excellent succession of plant microfossils similar to that of the Skull Creek Shale of north-central Wyoming. It is also correlative with the Taft Hill Member of the Blackleaf Formation of northwestern Montana (fig. 2).

The upper sandstone member of the Thermopolis overlies the middle shale member, probably conformably. It is a fine-grained arkosic sandstone unit that contains some interbedded shale in the middle part and represents deposition in a regressive near-shore marine and brackish-water environment. This sandstone differs from the lower sandstone member in that it contains feldspar and abundant heavy minerals. Glauconite is present in the upper part of the upper sandstone member. The upper sandstone member is probably equivalent to the Muddy Sandstone Member of north-central 
Wyoming and the Newcastle Sandstone of the Black Hills area of northeastern Wyoming and part of the Vaughn Member of the Blackleaf Formation in northwestern Montana (fig. 2).

The Mowry Shale conformably overlies the Thermopolis Shale. It consists of dark-gray to brownish-gray shale and mudstone interbedded with siltstone and sandstone. Near Bozeman the Mowry is very carbonaceous and contains plant fragments and thin streaks of coal, which suggests relatively quiet brackish-water deposition. Near Livingston the Mowry is micaceous and pyritic and commonly glauconitic; it contains spores and pollen which suggest deposition in a shallow restricted marine environment. The Mowry in the Livingston area is equivalent to the Mowry of Wyoming and is probably equivalent to the Bootlegger Member of the Blackleaf Formation in northwestern Montana (fig. 2).

At the base of the Upper Cretaceous are massive ridge-forming sandstones of the Frontier Formationwhich overlies the Mowry Shale, probably conformably. The boundary between the two formations is at the base of the Boulder River Sandstone Member. All the sandstones of the Frontier contain abundant heavy minerals and dark-gray chert, which give them a "salt-andpepper" appearance. Sedimentary features and faunal assemblages indicate that the sediments of the Frontier Formation in the Livingston area were deposited in an oscillating regressing sea that was shallow and brackish. The Frontier Formation at Livingston has not been precisely dated, but spores and pollen suggest that it approximately spans the lower half of the Cenomanian (fig. 2).

The Cody Shale conformably overlies the Frontier in the Livingston area and represents a transgressive return to deeper water marine conditions with the shoreline to the west. The Cody Shale consists of dark-gray to dark-brown shale interbedded with siltstone and sandstone. In the middle of the Cody is a persistent thinbedded glauconitic sandstone, named the Eldridge Creek Member by Roberts (1964c). This is an excellent marker bed and contains a shallow-water marine fauna that includes the short-ranging ammonite Scaphites depressus. The Cody Shale at Livingston is equivalent to the Niobrara Formation, Carlile Shale, and upper part of the Frontier Formation of central Wyoming.

The Telegraph Creek Formation is a shallow-water marine unit transitional between the underlying offshore marine Cody Shale and the overlying near-shore Virgelle Sandstone Member of the Eagle Sandstone. The gradual transition in sedimentation in this area reflects the gradual uplift of the Elkhorn Mountains and other structural units to the west and an eastward move- ment of the Cretaceous strandline. The Telegraph Creek Formation consists of thin beds of sandy siltstone and sandstone. Weed (1893, p. 16) referred to this part of the stratigraphic section at Cokedale as the "Tombstone sandstones." The Telegraph Creek Formation in this area very gradually changes in texture upward from the very fine grained upper shale member of the Cody Shale to the fine- to medium-grained Eagle Sandstone.

The Eagle Sandstone conformably overlies the Telegraph Creek Formation in the area west of Livingston and consists of sandstone with intercalated beds of coal and carbonaceous siltstone. These strata represent lagoonal, estuarine, deltaic, and swamp deposits laid down near ancient shorelines. The coal beds are commonly lenticular, but the zones in which they occur are laterally persistent. Some of the coal is commercial, and estimated reserves of more than 300 million tons are present (Roberts, 1966, p. A49-A51). A massive persistent quartzose sandstone at the base is called the Virgelle Sandstone Member. Locally, the uppermost beds of the Virgelle contain 1 percent or more magnetite concentrated in a regressive beach deposit.

Late in the Coniacian or early Santonian Stage of Late Cretaceous time, epeirogenic arching began in western Montana, and the Eagle sea regressed to the east. This period of orogeny and erosion was accompanied by volcanism, which formed the thick Elkhorn Mountains volcanic pile (Klepper and others, 1957, p. 31-41).

After withdrawal of the Late Cretaceous Eagle sea in western Montana, the area east of the Bridger Range and north of the Beartooth Range was gradually warped downward and formed the Crazy Mountains basin. This structural feature is elongated northwest and is approximately 40 to 75 miles wide and 100 to 130 miles long. The basin is asymmetrical, and more than 13,000 feet of sediment was deposited in its deeper (western) part during Late Cretaceous and Paleocene time (Roberts, 1963, p. B86). The sediment was derived predominantly from andesitic volcanic rock of the Elkhorn Mountains volcanic pile. The stratigraphic sequence for this part of the basin indicates that deposition was continuous and that the rocks grade laterally to the east and northeast into finer grained marine and nonmarine beds. The continental section near Livingston, Mont., is subdivided into the Livingston Group, which includes four formations of Late Cretaceous age, and the Fort Union Formation of Late Cretaceous and Paleocene age (Roberts, 1963). Formations of the Livingston Group are thick alternating series of coarseand fine-grained rocks that are characterized by rapid vertical and lateral variations commensurate with pulses of the Laramide orogeny. These rocks probably were 


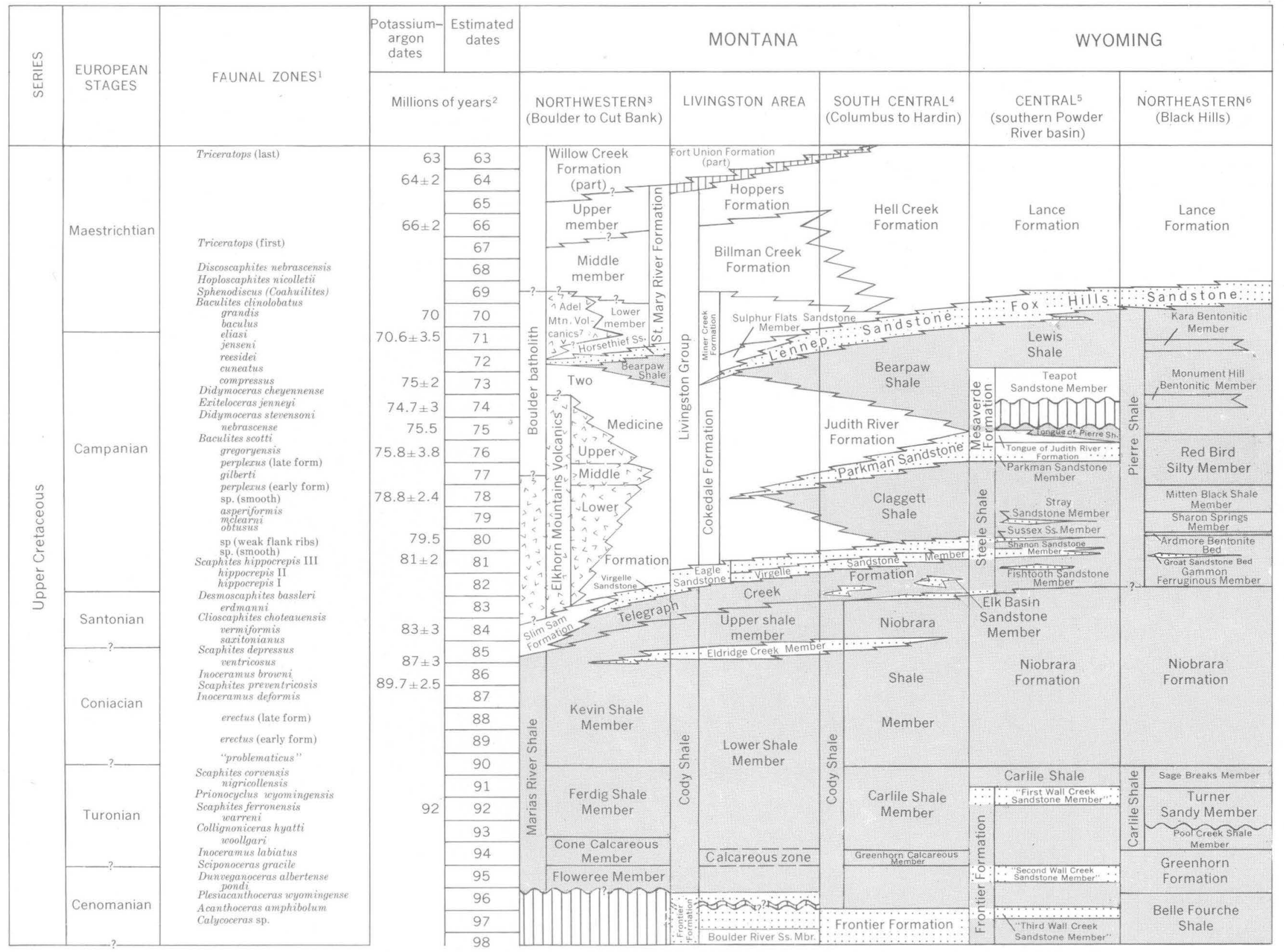




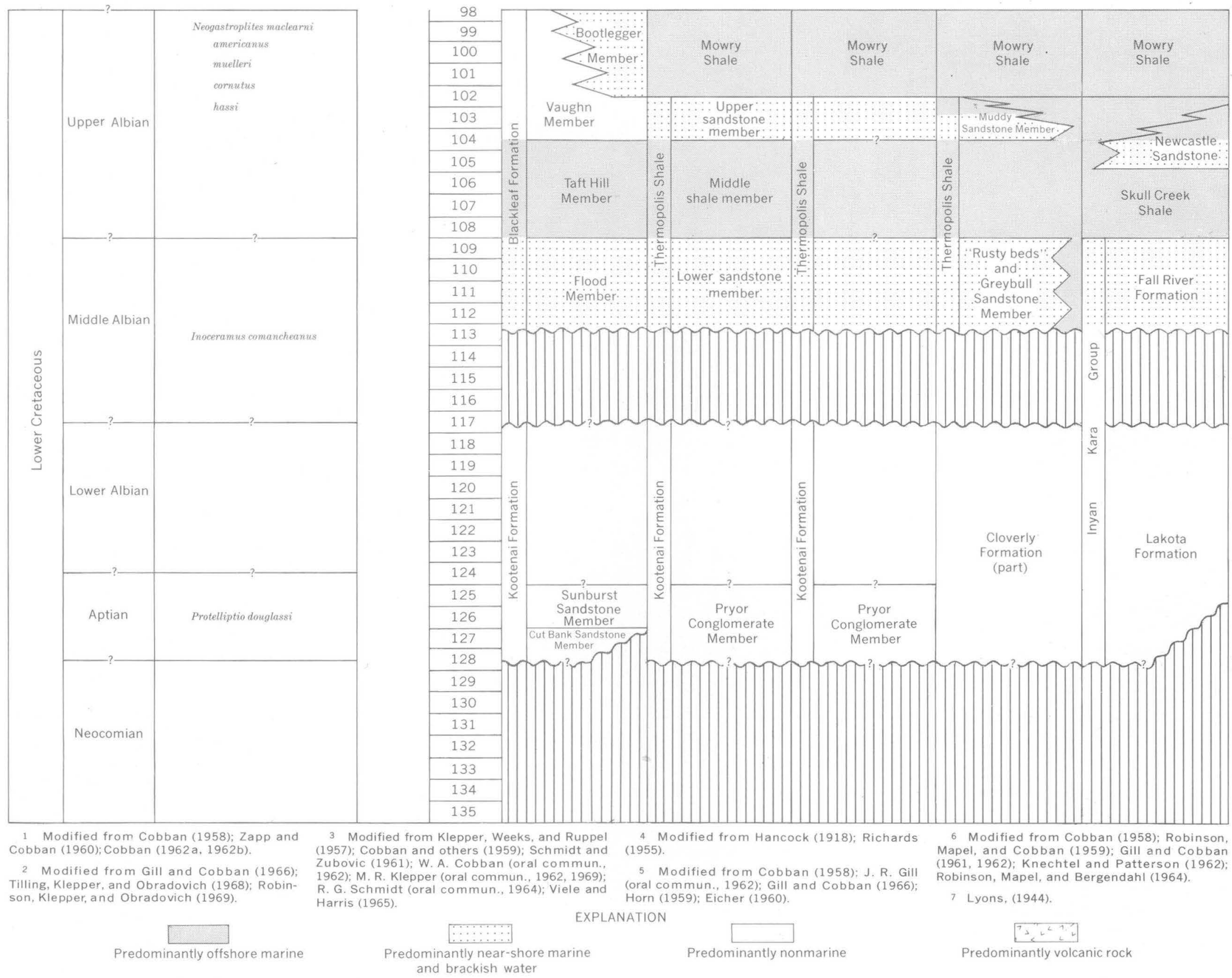

FIGURE 2.-Correlation and stratigraphic relations of Cretaceous rocks of the Livingston area, Montana, with other areas in Montana and Wyoming. 
deposited in fluvial channel systems or on associated extensive flood plains, near sea level, judging by their similarities to Holocene deposits found in such environments. The Livingston Group has been subdivided, in ascending order, into the Cokedale, Miner Creek, Billman Creek, and Hoppers Formations.

The Cokedale Formation is a nonmarine unit composed of siltstone and sandstone, and lesser amounts of mudstone, tuff, bentonite, and coal in the lower part; it correlates eastward with the Claggett Shale, the Judith River Formation, and Bearpaw Shale and in northwestern Montana with the Two Medicine Formation (fig. 2). The Cokedale rests conformably on the Eagle Sandstone at the type section at Cokedale, Mont. The Miner Creek Formation conformably overlies the Cokedale Formation and consists largely of alternating beds of nonmarine siltstone and sandstone-including a prominent ridge-forming unit, the Sulphur Flats Sandstone Member, at the base. The Miner Creek correlates eastward with the lower part of the Hell Creek Formation, and the Sulphur Flats Sandstone Member is the nonmarine facies of the marine Lennep Sandstone and Horsethief Sandstone (fig. 2). The Billman Creek Formation is a nonmarine sequence of red, purple, and green mudstone, tuff, and bentonite, including a few intercalated beds of sandstone; it correlates northward and eastward with the middle part of the Hell Creek Formation (fig. 2). The Billman Creek rests conformably on the Miner Creek Formation at the type section on Billman Creek, near Cokedale, Mont. The type Hoppers Formation, also nonmarine, is mostly sandstone and conglomerate interbedded with some siltstone, mudstone, and tuff ; it correlates northward and eastward with the upper part of the Hell Creek Formation (fig. 2).

The Livingston Group at Cokedale, Mont., is overlain by nonmarine sandstone and conglomerate that alternate with siltstone and mudstone; this sequence is assigned to the Fort Union Formation (Roberts, 1963, p. B89). The Fort Union includes three lithologic units: a lower conglomeratic sandstone member, a middle member of sandstone and mudstone, and an upper conglomeratic sandstone member; the top is every where an erosion surface. The lower member is assigned a Late Cretaceous age because of plant microfossils, stratigraphic position, and degree of erosion in source areas as implied by constituent rock types.

During deposition of the Fort Union Formation near Livingston, streams from the west dropped their sediment and created alluvial fans, channel-fill sands, deltas, and flood-plain deposits. The character of the rocks at the base of the Fort Union differs markedly from that of rocks of the underlying Livingston Group. The conglomerates in the Livingston Group are composed almost entirely of Cretaceous volcanic rock, whereas the conglomerates in the Fort Union contain mostly igneous, metamorphic, and sedimentary rock fragments derived from rocks of Precambrian, Paleozoic, and Mesozoic age. This significant change in provenance and an increased size of rock fragments suggest a closer source area and greater depth of erosion in the source area during deposition of the Fort Union Formation than during the deposition of the Livingston Group. Deposition of the Livingston Group was not restricted at the beginning to the Crazy Mountains basin. Sediments similar and equivalent to the Cokedale and Miner Creek Formations were deposited in the southern part of the Gallatin Range and the northwest corner of Yellowstone Park, in the southern part of the Madison Range, in areas immediately south of the Elkhorn Mountains, and at Maudlow. At some time during the deposition of the upper part of the Livingston Group, or Hell Creek equivalent, sedimentation ceased to the west and south; and near the close of deposition of the Livingston Group, sedimentation ceased to the north.

During deposition of the Fort Union Formation in the southwestern part of the Crazy Mountains basin, the borderland in the northern part of the present Gallatin Range was elevated and eroded. Later, in early Eocene time, the northern part of this ancestral Gallatin Range was covered by volcanic or volcanic-derived sedimentary rocks. At their northern extent-15 miles southwest of Livingston, near Chimney Rock, Mont. (Roberts, 1964e) - these are primarily coarse clastic rocks, flows, flow breccias, and mudflows, including the Crandall (?) Conglomerate at the base of the sequence. This boulder conglomerate consists of clasts of Precambrian igneous and metamorphic rock, Paleozoic and Mesozoic sedimentary rock, and lower Tertiary volcanic rock. Plant microfossils from a local carbonaceous claystone near the base of this sequence, stratigraphic and structural relations, and lithologic similarities with stratigraphic units of known age in the northern Absaroka Range and Yellowstone National Park area, Wyoming, indicate a correlation with the oldest units of the Eocene.

Post-Eocene bolson and fluvial deposits occur at the western edge of the area of this report (pl.1). For the depositional and structural history of these Cenozoic rocks, the reader is referred to Hackett, Visher, McMurtrey, and Steinhilber (1960) and Robinson (1961). Glacial and other Pleistocene deposits at the eastern edge of this report are discussed by Horberg (1940). 


\section{LARAMIDE DEFORMATION}

The interval of time for the Laramide orogeny varies geographically in the Rocky Mountain region. Therefore, locally one must identify the interval of mountain building and basin development assigned to the Laramide. In the Livingston area, volcanic pebbles in the Virgelle Sandstone Member of the Eagle Sandstone suggest a beginning of uplift to the west in early Eagle time. However, a flood of volcanic debris in the basal part of the overlying Livingston Group indicates that the first major tectonic pulse that began Laramide deformation took place in the Livingston area at the end of Eagle time. The final uplift of the Laramide orogeny in the Livingston area is of early Eocene age. North of Livingston this uplift was accompanied by major intrusions in the Castle, Crazy, and Little Belt Mountains; south of Livingston this uplift produced the Crandall(?) Conglomerate. Thus, for the purposes of this report, the term Laramide refers only to those tectonic events transpired from the beginning of deposition of the Livingston Group (late Santonian Stage of Late Cretaceous time) to the close of deposition of the Crandall(?) Conglomerate (early Eocene Epoch of early Tertiary time). The structural pattern established during the Liramide deformation was subsequently modified by normal faulting and volcanism.

Epeirogenic arching in the vicinity of the Elkhorn Mountains, near Boulder, Mont., late in the Coniacian or early Santonian Stage of Late Cretaceous time (fig. 2) was accompanied by erosion and truncation of beds as old as the Lodgepole Limestone of Early Mississippian age. This episode of uplift and erosion was followed by the volcanism which created the thick Elkhorn Mountains volcanic pile (Klepper and others, 1957). Contemporaneous with this period of orogeny, the Eagle sea gradually withdrew from western Montana and the area east of the Bridger Range and north of the Beartooth Range gradually subsided to form the Crazy Mountains basin (pl. 3).

The Crazy Mountains basin is bounded by major Laramide structures: the Beartooth and Bridger uplifts on the south and west; the Little Belt and Big Belt uplifts on the north and northwest; the Lake Basin fault zone on the northeast; and the Nye-Bowler lineament, the Pryor uplift, and a narrow connection with the Bighorn Basin on the southeast (pl. 3). Also, stratigraphic information from drilling suggests that a slight arch connects the Pryor and Little Belt uplifts and provides additional definition to the northeast side of the basin.

Although the Crazy Mountains basin formed during the period of Laramide basin development, its geometry was probably influenced by Precambrian structural and sedimentary elements. Along the northeastern edge of the basin is the Lake Basin fault zone or Lake Basin lineament and along the southeastern edge is the NyeBowler lineamént. These Laramide features that border the basin probably represent reactivated Precambrian wrench faults or fault zones at depth. The NyeBowler lineament, mapped and described by Wilson (1936), is a compound feature that includes folds, en echelon faults, and a few small volcanic centers which extend from the Pryor Mountains northwestward parallel to the Beartooth uplift (pl. 3). The en echelon folds between Livingston and Bozeman may be a western extension of the Nye-Bowler lineament. The surface en echelon faults trend northeast, which suggests leftlateral movement. Wilson (1936, p. 1182) concluded that these faults were produced near the surface by lateral movement along a buried fault plane in the basement complex. A similar origin had previously been proposed by Chamberlin (1919) for en echelon faults of the Lake Basin fault zone (pl. 3). Osterwald (1961) and Smith (1965) summarized the earlier work of Chamberlain and Wilson and extended these lineaments regionally as transcurrent fault zones.

Battle Ridge, a prominent northeast-trending topographic feature in the western part of the Crazy Mountains basin (pl. 3) is also probably a surface expression of a reactivated Precambrian fault at depth. This structural element, projected northeastward, divides the Crazy Mountains basin in two dissimilar parts. In the northern part, the basin is underlain by a thick sequence of sedimentary rock, the LaHood Formation of the Belt Supergroup of late Precambrian age, whereas in the southern part these rocks are absent. McMannis (1963, p. 415) reported 10,250 feet of LaHood Formation north of the Pass fault in the Bridger Range, and his generalized isopach map (1963, p. 412) suggests thicknesses for the Belt deposits that range from 0 to 15,000 feet in the northern part of the Crazy Mountains basin. The presence of this thick wedge of Belt Supergroup must have influenced the structural response of the younger rock units to regional stresses. Paralleling the Battle Ridge element to the south are the Emigrant fault and related structures (pl. 3). Extension or projection of this structural element to the north-northeast, approximately to the intersection of the Shawmut and Big Coulee-Hailstone structures, suggests structural control similar to that of the Battle Ridge element. Appalachian or symmetrical folding is characteristic of the northern part of the Crazy Mountains basin, and asymmetrical folding and en echelon fold axes are characteristic of the southern part. Also, in the northern part of the basin most of the intrusive rocks are alkalic, and in the southern part most are calc-alkalic. A fourth 
significant difference is that in the southern part there are numerous calcite dikes-some of optical quality (Stoll and Armstrong, 1958) - whereas none are reported in the northern part (pl.3).

The Bridger Range on the west edge of the Crazy Mountains basin is the result of a complex uplift and basinward (eastward) thrusting, and the Beartooth Range on the southwest edge is the result of a complex uplift and basinward (northeastward) thrusting. For a detailed study of the structural geology of the Bridger Range, the reader is referred to McMannis (1955) and, for the Beartooth Range, to Foose, Wise, and Garbarini (1961). These uplifts developed slowly during deposition of the Livingston Group and Fort Union Formation, and the thrusting occurred after deposition of the Fort Union. Lateral forces that produced the thrusting were accompanied by a lesser opposing force from within the basin, and as the Bridger and Beartooth uplifts evolved, these structural elements were forced basinward. In the area between Bozeman and Livingston, arcuate northwest-trending en echelon folds formed, each convex toward the southwest and parallel to the axis of the Crazy Mountains basin (pls. 1, 3). In the Livingston area, folding that accompanied thrusting produced asymmetric anticlines that had the steeper dips on the south west flanks. The Canyon Mountain anticline grew until it became recumbent on its southwest flank (Roberts, $1964 \mathrm{a}, \mathrm{b}$ ). The Canyon Mountain anticline is related to the complex Beartooth uplift and represents essentially a pivot at the Beartooth uplift's west end with basinward movement increasing to the east.

Subsidence and deposition were greater in the western part (west of the Emigrant fault trend) of the Crazy Mountains basin than in the eastern part; both were greatest in late Campanian and Maestrichtian time. The asymmetric subsidence of the basin may have been related to rock transfer at depth and to the consequent extrusion of the Elkhorn Mountains Volcanics and the intrusion of the Boulder batholith in nearby areas to the west; however, an asymmetric configuration seems common to most Laramide intermontane basins of Montana, Wyoming, and Colorado (Prucha and others, 1965, p. 975). Deposition was continuous during latest Cretaceous and Paleocene time in the deepest part of the basin, where more than 13,000 feet of sediments, derived predominantly from volanic rock, was deposited. The physical similarities of rocks of the Livingston Group and Fort Union Formation suggest that deposition in the western part of the basin took place near sea level and that the rate of sedimentation closely balanced the rate of subsidence.
Extensive erosion accompanied the uplift, and by Late Cretaceous time parts of the Bridger and Beartooth uplifts were truncated to expose Precambrian rocks (as shown by the basal conglomerate of the Fort Union Formation, which in the Livingston area contains rock fragments derived from Precambrian, Paleozoic, and Mesozoic rocks).

During folding, lateral movement of thick competent sandstone beds, such as in the Eagle Sandstone, caused local folding and shearing of the intervening incompetent finer grained clastic beds. Squeezing that accompanied this movement produced lenticular beds, and in local areas of intense folding, bedding-plane faults developed under shear. Where lateral compressional forces were most severe, failure of the folds occurred and large thrust or high-angle reverse faults developed (fig. 3).

Most thrusts in the Bridger Range initially dipped west and those in the Beartooth Range generally dipped southwest. Basinward dips are present locally and are the result of subsequent folding. In the area west of Livingston, thrust faults developed in an en echelon arrangement paralleling the folds. Field relations of the Livingston faults suggest that the direction of compressive force was toward the south west and that initial dips of the faults were to the north. Individual thrust faults, in this area, commonly vary from low-angle thrust faults to high-angle reverse faults. Similar structural features also occur along the perimeter of the Bighorn Basin (Chamberlin, 1940) and the Wind River Basin (Keefer, 1970).

Folding and thrusting continued during post-Fort Union and pre-Wasatch time in the Livingston area, but with less magnitude than during Fort Union time. Earlier thrust plates, such as those on the south flank of the Canyon Mountain anticline, were folded during this post-Fort Union and pre-Wasatch time, locally changing the dip to a basinward direction. Thrust faults with an initial basinward (north) dip then developed on the north flank of the Canyon Mountain anticline. On the southwest flank of the Canyon Mountain anticline a complex arrangement of thrust faults separated by zones of oxidized sedimentary rocks suggests several pulses of thrusting with intervening periods of weathering and erosion (Roberts, $1964 \mathrm{a}, \mathrm{b}$ ).

During deposition of the Fort Union Formation in the southwestern part of the Crazy Mountains basin, the borderland in the northern part of the Gallatin Range and the Bridger Range continued to rise and restricted the western limit of the Fort Union of Montana to this basin. The Fort Union and older rocks were folded, probably near the close of the Paleocene or 


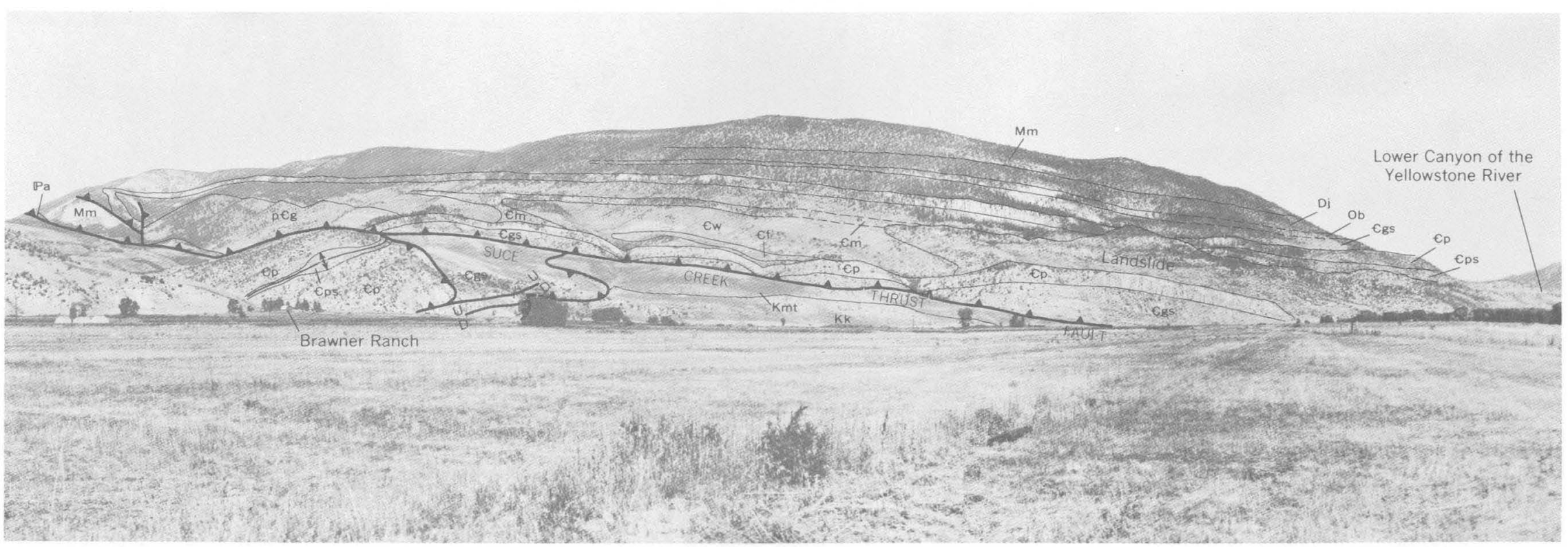

Frgure 3.-View northwest of the exposed Precambrian core of the recumbent Canyon Mountain anticline with the Suce Creek thrust fault along its base. Photograph taken from the center of the NE1/4 sec. 27, T. 3 S., R. 9 E. Geology shown on plate 1 or in Roberts (1964a). p €g, Precambrian rocks; Єf, Flathead Quartzite; $€ w$, Wolsey Shale; €m, Meagher Limestone; €ps, Park Shale; €p, Pilgrim Limestone; €gs, Grove Creek and Snowy Range Formations; Ob, Bighorn Dolomite; Di, Jefferson Dolomite; Mm, Madison Group; $\mathbb{P a}$, Amsden Formation; Kk, Kootenai Formation; Kmt, Mowry and Thermopolis Shales. 
beginning of the Eocene. South of the Canyon Mountain anticline, which formed the southwestern barrier of the basin, the ancestral Gallatins continued to be eroded, and no Fort Union sediments have been reported in this area. In early Eocene time the area of the Gallatin Range was covered by sedimentary and volcanic rocks, none of which extended north of the Canyon Mountain anticline. These Eocene deposits remain relatively undeformed in contrast to the underlying folded formations (Roberts, 1964e), which indicates that the last major period of folding for this area occurred near the end of Paleocene or the beginning of Eocene time. This conclusion was also reached by W. J. McMannis (written commun., 1962) in the Garnet Mountain area south of Bozeman, Mont. He observed a carbonaceous siltstone of Wasatchian provincial age at five separate localities, which do not differ in elevation by more than 800 feet. McMannis attributes the differences in elevation to post-volcanic (Wasatchian) tilting and warping related to post-Laramide normal faults bordering the Gallatin Range and to initial differences in elevation on the pre-volcanic erosion surface.

In post-Paleocene time, after the folding and thrust faulting, rocks in the Livingston area were intruded by a few dikes and sills of diorite. These intrusions generally occur along tension fractures or faults that are parallel to fold axes (fig. 4). Northeast of the Livingston area, laccoliths, stocks, sills, and several generations of dikes were also intruded at this time (pl. 3) along the axis of the Crazy Mountains basin (Wolff, 1938, p. 1625), along tension and shear joints produced during the syclinal folding. Wolff (1938) described an older

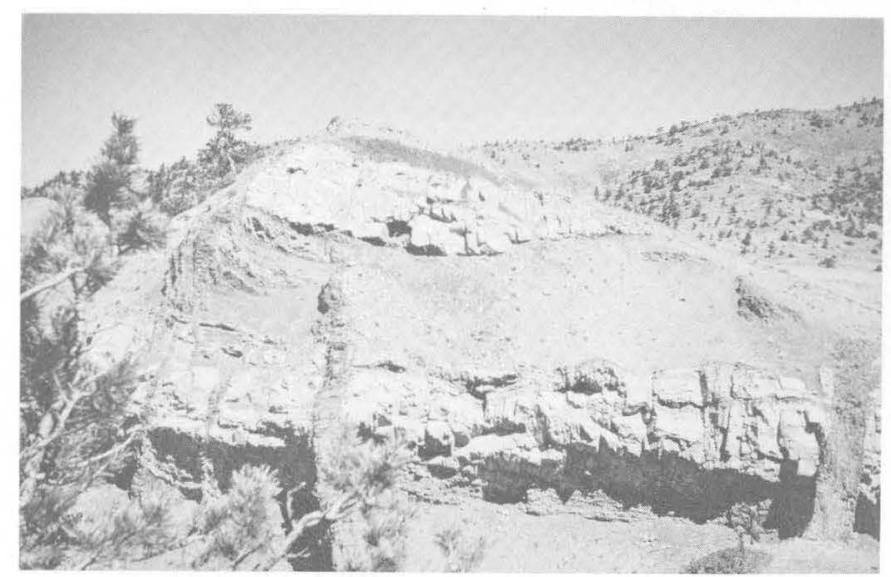

Figure 4.-Andesitic dikes cutting mudstones and sandstones of the Billman Creek Formation in the NE1/4 sec. 13, T. 2 S., R. 8 E. The dikes have intruded along parallel tension fractures without offsetting parts of the lower massive sandstone. The dike left of the center of the photograph did not penetrate the upper massive sandstone. calcalkalic series, chiefly in the south-central part of the Crazy Mountains basin, and a younger alkalic series, found chiefly in the north-central part of the basin. Uplift and erosion have now bared these igneous bodies which form the Crazy Mountains.

Post-Laramide epeirogenic uplift, near the close of the Tertiary, raised the Crazy Mountains basin and adjacent areas about 5,000 feet above their previous elevations. Large-scale faulting has also characterized the latest tectonic activity in the area and may have accompanied the regional uplift. The dominant movement was nearly vertical on normal faults. Displacement along these faults ranges from a few feet to the more than 5,000 feet on the Emigrant fault (Horberg, 1940). The faults of small displacement are generally parallel to fold axes and are most abundant near the crests of anticlines (pls. 1,3), whereas the faults of large displacement, such as the Emigrant fault, trend northnortheast. The association of the smaller normal faults with the folds indicates that they are older than the larger faults. The Emigrant fault may have been active since Late Cretaceous time, as its northeast trencl parallels other structural elements of this age. Evidenco in the adjacent Gallatin Range that the Emigrant fault was active in Eocene time includes the greater tilting of Eocene volcanic rocks that are low stratigraphically in the Hyalite Peak Volcanics, compared with the tilting of those higher in the sequence (R. A. Chadwick, written commun., 1969). Horberg (1940, p. 293) presented evidence that the Emigrant fault was intermittently active from Miocene to Holocene time.

\section{CRETACEOUS SYSTEM}

\section{LOWER CRETACEOUS SERIES}

The Lower Cretaceous Series in the area west of Livingston consists of the Kootenai Formation, Thermopolis Shale, and Mowry Shale. The series is 1,250 feet thick and consists of continental clastic and carbonate rocks in the Kootenai Formation and marine shale and mudstone interbedded with quartzose sandstone in the Thermopolis and Mowry Shales.

\section{KOOTENAI FORMATION}

The Kootenai Formation is a nonmarine sequence of conglomerate, sandstone, siltstone, claystone, mudstone, limestone, and tuff of Early Cretaceous age (fig. 2) that unconformably overlies the Morrison Formation (Jurassic). The Kootenai may be divided into two units: (1) a basal massive crossbedded conglomerate, conglomeratic sandstone, and coarse-grained sandstone called the Pryor Conglomerate Member, and (2) an unnamed 
sequence of variegated siltstone, claystone, mudstone, limestone, and tuff interbedded with calcareous sandstone. The Kootenai Formation is 245 to 295 feet thick, including the basal 24- to 37-foot Pryor Conglomerate Member, and is unconformably overlain by the lower sandstone member of the Thermopolis Shale at its reference section. A reference section of the Kootenai is shown in figure 5 and is described in measured section 1.

Lower Cretaceous rocks of the Kootenai Formation in the area west of Livingston were first mapped by Iddings and Weed (1894) as the Dakota Sandstone. Calvert (1912a, p. 31) later correlated the sequence with the Kootenai Formation as established near Great Falls, Mont., by Fisher (1908, p. 78-80; 1909, p. 30). Fisher (1908, p. 93) pointed out that the Kootenai near Great Falls extended southward through Montana into the southern part of the Bighorn Basin, Wyoming, where equivalents were called the Cloverly Formation. The correlation was later extended southward to Colorado Springs, Colo., by Lee (1927, p. 26) who established that equivalents of the Cloverly were part of the Dakota Group of Colorado.

A comprehensive review of the conglomerate of the Cloverly Formation and its equivalents was made by Lammers (1939, p. 113). He suggested an unconformity $(1939$, p. 118) at the base of the Cloverly conglomerate or its equivalents and assigned coal-bearing rocks beneath the conglomerate to the Upper Jurassic. The unconformity was later confirmed and described by Cobban $(1945$, p. 1270, 1281), and nonmarine rocks beneath the unconformity were assigned to the Morrison Formation. The unconformity described by Cobban (1945, p. 1270) near Great Falls, Mont., is correlative with the unconformity at the base of the Kootenai at Livingston, Mont.

The basal conglomerate, conglomeratic sandstone, and sandstone are referred to as the Pryor Conglomerate Member of the Cloverly Formation in north-central Wyoming (Hares, 1917, p. 429; Bowen, 1918, pl. 25) and the Pryor Conglomerate Member of the Kootenai Formation in southwestern Montana (Roberts, 1965,

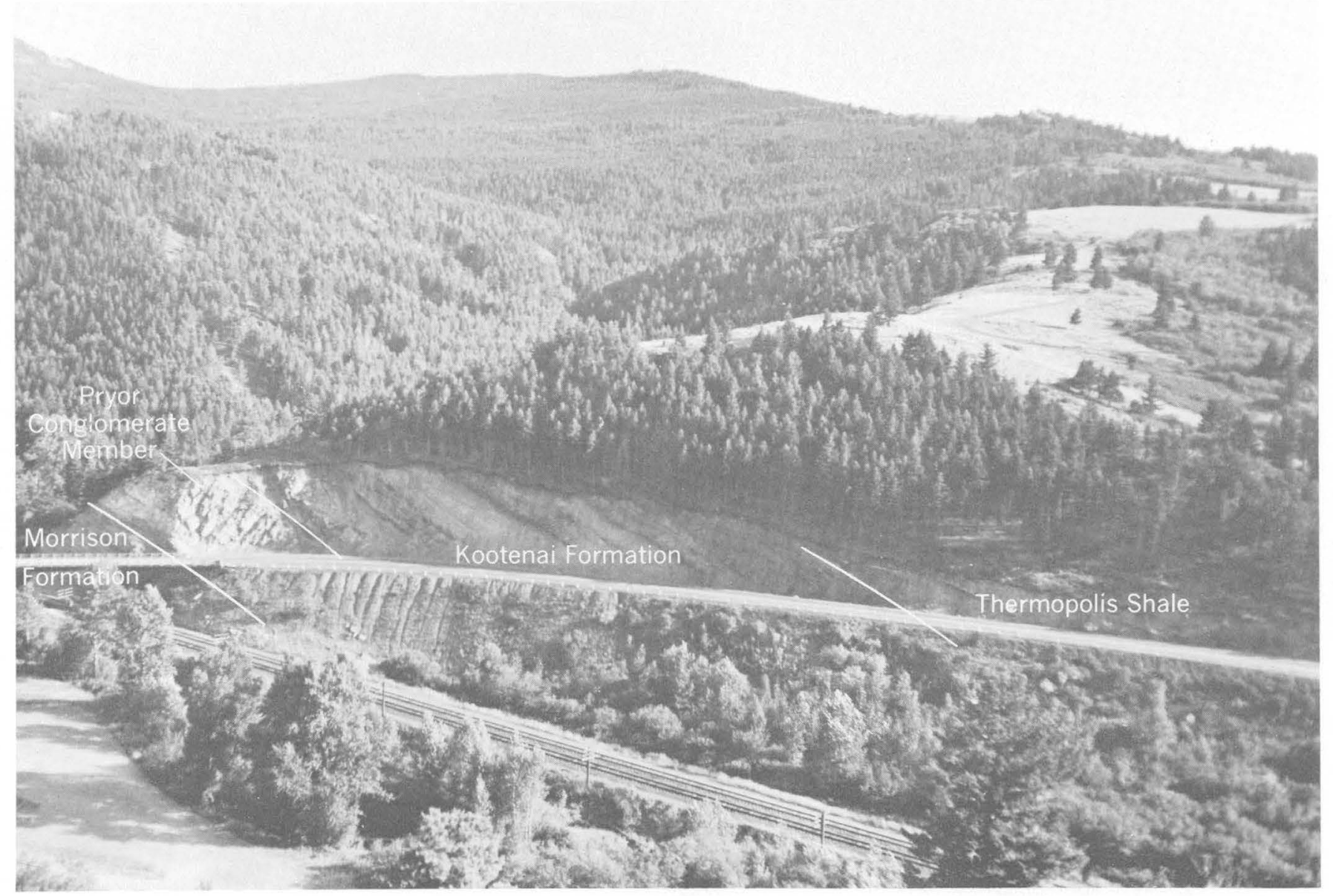

Figure 5.-Reference section of Kootenal Formation on the west flank of Chestnut Mountain anticline in the NE1/4 sec. 25, T. 2 S., R. 6 E. (measured section 1). View is south: west end of Rocky Canyon at the left edge of the photograph. 
p. B55). Equivalent beds elsewhere in Montana include: the Cut Bank and Sunburst Sandstone Members of the Kootenai Formation on the northwest flank of the Sweetgrass arch area of northwestern Montana, the Sunburst Sandstone Member in the subsurface over much of the Sweetgrass arch (Cobban, 1955, p. 107), the Third Cat Creek Sand of central Montana (Reeves, 1927 , p. 48 ; 1931, p. 139), and the Lakota Formation of southeastern Montana and northeastern Wyoming: (Darton, 1901; Rubey, 1931; Waagé, 1959; and Post and Bell, 1961).

The Pryor Conglomerate Member is not exposed between the type section in the Pryor Mountains and Nye, Mont. (about 35 miles west of Red Lodge, Mont.). It is either buried by younger deposits or cut out by faulting. Gardner, Hendricks, Hadley, and Rodgers (1945) extended the Pryor across this area in the subsurface. The Pryor crops out as a persistent ridge along the north flank of the Beartooth Range from Nye to Livingston. South of Livingston along the north end of the Gallatin Range the basal conglomeratic sandstone of the Kootenai forms prominent cuestas and hogback ridges. The overlying fine-grained clastic rocks and limestones are poorly exposed and generally form red clay soil-covered slopes and valleys.

\section{LITHOLOGIC GOMPOSITION}

The lower lithologic unit, the Pryor Conglomerate Member of the Kootenai Formation, is a persistent massive ridge-forming unit of conglomerate, conglomeratic sandstone, and sandstone. At stratigraphic section 1 on the west flank of the Chestnut Mountain anticline, the Pryor is 37 feet thick and is crossbedded, well indurated, poorly sorted, and has scour-and-fill structures. The lower part of the unit is conglomerate or conglomeratic, and the upper part is sandstone. The coarser fragments are mostly subrounded to rounded pebbles in a matrix of poorly sorted sand grains. The pebbles are generally less than 1 inch in diameter but may be as much as 2 inches. The pebbles are dominantly gray or black chert, and a few are quartzite and limestone; they resemble rocks from the Madison Group and the Amsden, Quadrant, and Phosphoria Formations. Pebbles are commonly concentrated on some of the cross-stratification surfaces. Along the southern flank of Canyon Mountain, about 12 miles southwest of Livingston, the Pryor Conglomerate Member contains repeated reverse graded bedding (fig. 6). The sandstone is gradational with the conglomerate, both laterally and vertically. Sandstone also forms channel-fill deposits as well as the matrix within the conglomerates. The sandstones are composed mainly of angular to subrounded grains of quartz, quartzite, and chert cemented by silica.

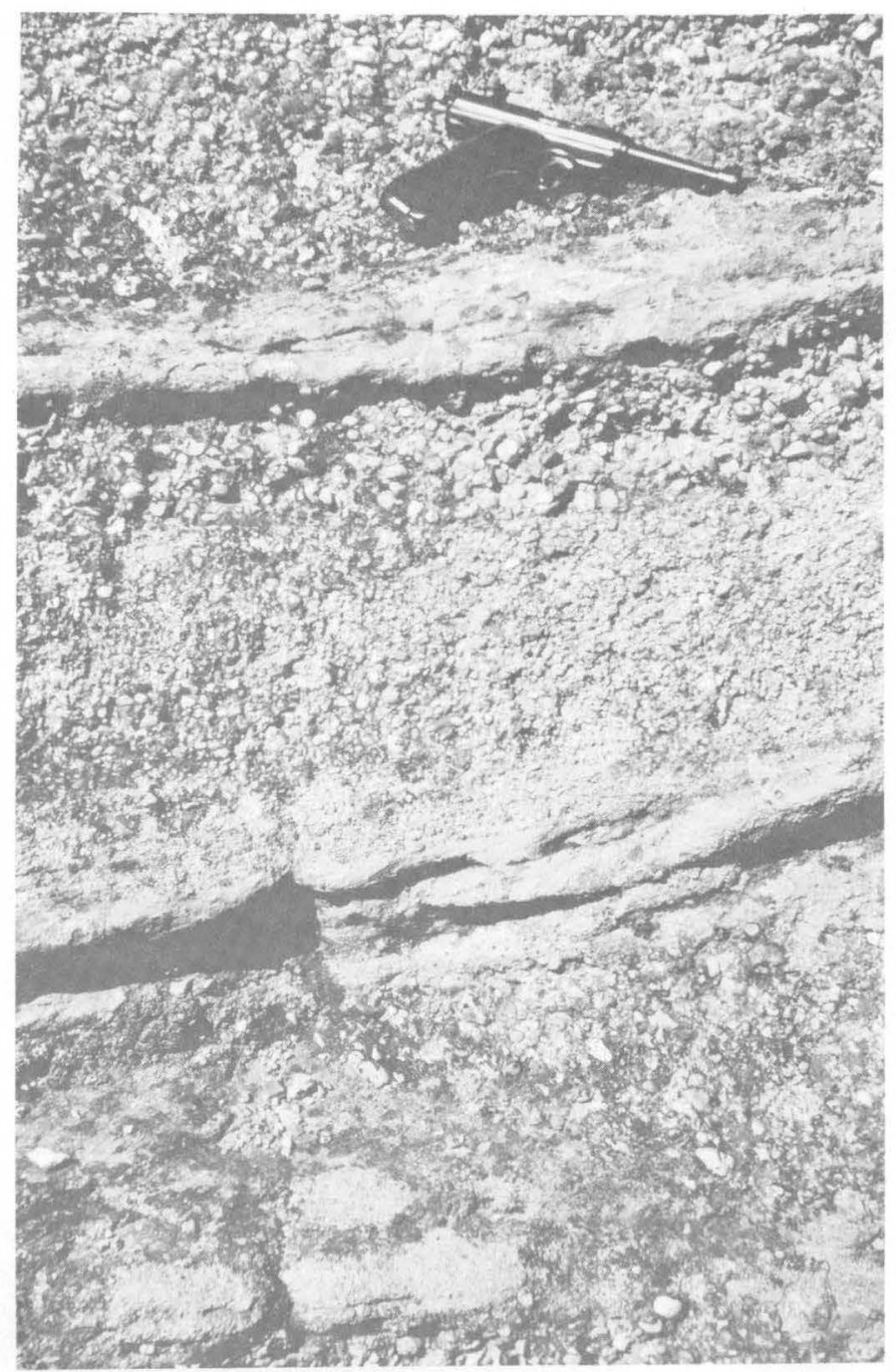

Figure 6.-Pryor Conglomerate Member of the Kootenai Formation in sec. 28 , T. 3 S., R. 9 E., showing repeated reverse graded bedding.

The source for the conglomeratic unit was probably upper Paleozoic and Mesozoic rocks to the west (Lammers, 1939, p. 114), where uplift had taken place during Late Jurassic and Early Cretaceous time. This uplift was probably in central or southeastern Idaho as suggested by Armstrong and Oriel (1965, p. 1854). A western source is also implied by the southeastward pinchout of the Pryor Conglomerate Member in the northern part of the Bighorn Basin (Moberly, 1960, p. 1147). Directional features that include cross stratification, pebble imbrication, current lineations, and ripple marks indicate sediment transport by northeastward-flowing currents. The conglomerate, conglomeratic sandstone, and sandstone of rather uniform thickness were deposited on a surface of very little relief, generally on Morrison coal-bearing swamps. In the vicinity of Livingston, 
Mont., characteristics such as scour-and-fill structures, crossbedding, poor sorting, local wood fragments, rounded chert pebbles, and current bedding indicate a fluvial origin. The widespread distribution and the generally polished surface, roundness, and concentration of the pebbles suggest that these accumulations were repeatedly reworked, leaving only the most resistant rocks as a lag gravel. The well-rounded and polished chert pebbles were originally interpreted as gastroliths (Hares, 1917); however, additional observations of these widespread pebbles throughout similar sequences led Stokes (1942, p. 18-19) and others to abandon this interpretation in favor of wind polishing prior to deposition.

Overlying the basal Pryor Conglomerate Member is a very poorly exposed sequence of variegated red, purple, green, and gray siltstone, claystone, mudstone, limestone, and tuff that contains nonpersistent beds of sandstone (refer to measured section 1). The unit is of terrestrial origin; the limestone is lacustrine. Some of the beds are tuffaceous or contain claystone of probable volcanic origin.

The part of the Kootenai Formation above the Pryor Conglomerate Member in the area west of Livingston and in the northern part of the Gallatin Range was deposited on an extensive lowland bordered on the west by highlands. Streams from the west dropped their sediment on alluvial fans, in channels, and on flood plains. The grain size of sandstones decreases from west to east, as shown in the stratigraphic sections near Bozeman and Livingston (refer to measured sections $1-3)$. During the close of deposition of the Kootenai, a very large region including the Livingston area was covered by a lake in which mudstone and limestone were deposited. This lake or series of lakes extended at least from Teton County in northwestern Wyoming (Love, 1956, p. 77) northward into Canada and from Bozeman eastward to Harlowton in central Montana. Aphanocrystalline limestones near Bozeman contain molds of unidentifiable leached fossils; however, southeast of Bozeman, in the NE1/4 sec. 25, T. 3 S., R. 6 E. in the Mystic Lake quadrangle (Roberts, $1964 \mathrm{~g}$ ) and in the SE $1 / 4$ sec. 3, T. 4 S., R. 7 E. in the Maxey Ridge quadrangle (Roberts, 1964e), a very fossiliferous limestone is exposed. This limestone is almost a coquina of small fresh-water gastropods, pelecypods, and ostracodes and is an excellent marker bed for the Kootenai in this part of the report area.

Tuffs and claystones or mudstones in the Kootenai were probably derived, in part, from volcanic ash. Richards $(1955$, p. 43$)$ described bentonite and bentonitic shale from the middle unit of the Cloverly Formation along the northeast flank of the Bighorn Mountains.
In the Bighorn Basin, equivalent strata contain bentonitic mudstone (Moberly, 1960, p. 1145). The volcanic source for these rocks has yet to be defined.

\section{AGE AND CORRELATION}

The Kootenai Formation in Montana is considered to be of Early Cretaceous age (fig. 2). In some parts of Montana and northern Wyoming, it contains dinosaur, fish, and turtle bones; plant impressions; fresh-water mollusks; and ostracodes. Over most of western Montana there are one or more limestones, commonly near the top of the formation, that locally contain abundant molds and casts of fresh-water gastropods, pelecypods, and ostracodes. A collection of fresh-water mollusks from the Kootenai Formation near Harlowton, Mont., was described by Stanton (1903, p. 194), who assumed that the fauna was not older than Early Cretaceous and was more probably at about the base of the Upper Cretaceous. R. W. Brown (1946, p. 238) reviewed the floras of the Kootenai and Morrison Formations of Montana and their equivalents in Alberta, Canada, and concluded that the flora above what is now considered the basal part of the Kootenai is Early Cretaceous in age, and the flora below the unconformity at the base of the Kootenai is equivalent to that in the Morrison Formation of Late Jurassic age. Peck (1941, p. 286) identified the charophytes Atopochara trivolvis, Aclistochara mundula, and Clavator harisi and the ostracode Metacypris angularis from the upper part of the Kootenai of southwestern Montana and correlated the Kootenai with part of the Trinity Group (Aptian) of Texas. Cobban and Reeside (1952b) also assigned an Aptian age to the Kootenai Formation. Yen (1951, p. 2) described a fluviatile fauna from the Kootenai near Harlowton, Mont. (originally described by Stanton 1903) and correlated part of the formation with the Cloverly Formation in Wyoming and part with the Peterson Limestone of the Gannett Group in Wyoming and Idaho. Near the south border of Glacier National Park the shale and limestone unit at the top of the Kootenai contains Unio reesideanus Yen (Cobban, 1955 , p. 109), which is presently known only from the Kootenai of Montana or its equivalent.

Along the north shore of Mystic Lake (Roberts, $1964 \mathrm{~g}$ ) in the NE $1 / 4$ sec. 25 , T. 3 S., R. 6 E., a limestone contains ostracodes that are mostly steinkerns. Occasionally, a few poorly preserved fossils were found; however, preservation is generally too poor for generic determination. One species resembles $C y p r i d e a$ anomala described by Peck from the Kootenai Formation (I. G. Sohn, written commun., 1963). The same limestone, in sec. 3, T. 4 S., R. 7 E., contains at least two kinds of fresh-water snails. Southwest of Livingston, near Vir- 
ginia City, Mont., the Kootenai Formation contains Botryococcus, a fresh-water algae whose presence suggests lacustrine or possibly deltaic deposition ( $\mathrm{R}$. H. Tschudy, written commun., 1962).

\section{THERMOPOLIS SHALE}

The Thermopolis Shale was named and described by Lupton (1916, p. 168) for about 700 feet of dark-gray shale and some lenticular sandstone beds exposed in the Bighorn Basin near Thermopolis, north-central Wyoming. Lupton's original Thermopolis Shale was underlain by the Greybull Sandstone Member of the Cloverly Formation that is now included as the basal member of the Thermopolis (as used by Eicher, 1960) (fig. 2). The upper half of his Thermopolis Shale is now the lower part of the Mowry. The Muddy Sandstone is the upper member of the Thermopolis (fig. 2), or a separate formation.

Reeside (1944) first used the term Muddy Sandstone Member of the Thermopolis Shale; however, he continued using Thermopolis Shale as it was originally defined by Lupton (1916, p. 168) and made the Muddy Sandstone the medial member of the Thermopolis. Love (1948, p. 106) and Thompson, Love, and Tourtelot (1949) proposed that the Thermopolis Shale be restricted to the interval between the Cloverly Formation and the Muddy Sandstone Member; that the Muddy Sandstone be considered a formation; and that the shale interval between the Muddy Sandstone and the Mowry Shale be included with the Mowry. Most stratigraphers have adopted these redefinitions as in the Buffalo-Lake De Smet area, Wyoming, Mapel $(1959$, p. 41$)$ and in the Shotgun Butte area southwest of Thermopolis, Wyo., Keefer and Troyer (1964, p. 18) placed the Thermopolis-Mowry boundary at the top of the Muddy Sandstone Member. In certain areas of central Wyoming the Muddy Sandstone is a mappable unit, but in other areas it is not and is included as the upper member of the Thermopolis Shale (fig. 2).

The basal member of the Thermopolis Shale near Livingston includes a clastic unit equivalent to the Greybull Sandstone Member. Darton (1904, p. 398-399) originally included a similar clastic unit, exposed along the east side of the Bighorn Basin, Wyoming, in the Cloverly Formation. Later, Hintze (1915, p. 15) named the Greybull Sandstone Member and assigned it to the upper part of the Cloverly Formation in north-central Wyoming. Hewett and Lupton (1917, p. 19) defined the boundary between the Thermopolis Shale and Cloverly Formation as the top of the Greybull Sandstone Member of the Cloverly. Subsequent work, however, has shown that the Greybull Sandstone disconformably overlies older rocks, is gradational with the overlying
"Rusty beds," and should not be included in the Cloverly. The "Rusty beds" were described by Washburne (1908, p. 350) as the basal member of the Colorado Formation in the Bighorn Basin, Wyoming. Eicher (1960) reviewed the stratigraphy and nomenclature of the Thermopolis Shale and "Rusty beds" and included the "Rusty beds"-Greybull Sandstone interval in the Thermopolis. He also considered the base of the Thermopolis to be disconformable on the Cloverly Formation (1960, p. 15). Most stratigraphers now include these units in the Thermopolis as shown in figure 2. The "Rusty beds" and Greybull Sandstone Member are a persistent transgressive sequence at the base of the marine Cretaceous in north-central Wyoming and southcentral Montana.

Iddings and Weed (1894) mapped a unit, the Colorado Formation, in the northern Gallatin Range, which probably includes the Thermopolis Shale, Mowry Shale, and Frontier Formation of this report. They correlated their Colorado Formation with the Benton Shale and the Niobrara Limestone (Iddings and Weed, 1894, p. 2). The massive quartzite in the upper member of their Dakota Sandstone was correlated with the Greybull Sandstone Member of the Cloverly Formation of north-central. Wyoming by Lee $(1927$, p. 65$)$. Calvert (1912a, p. 31) combined the Colorado and Montana Formations of Iddings and Weed as the Colorado Shale. Skeels $(1939$, p. 817) included the rocks above the Cloverly Formation and beneath the Telegraph Creek(?) Formation as the Colorado Group. He (1939, p. 817) divided the Colorado Group into a lower unit that includes the Thermopolis Shale, Mowry Shale, and Frontier Formation and an upper unit that includes the Carlile and Niobrara Formations. McMannis (1955, p. 1406), in the adjoining area to the northwest in the Bridger Range, combined the poorly exposed sections between the Kootenai Formation and the Eagle Formation as the Colorado Formation. In the adjoining area to the east, Richards (1957, p. 414) mapped the interval between the Kootenai Formation and the Virgelle Sandstone (basal member of the Eagle Sandstone) as the Colorado Shale.

In the Livingston area, the Thermopolis Shale unconformably overlies the Kootenai Formation and is overlain, apparently conformably, by the Mowry Shale. The Thermopolis consists of marine shale and sandstone, including a basal sandstone member that is 35 to 50 feet thick; a middle mudstone or shale member, 350 to 390 feet thick; and an upper sandstone member, 90 to 105 feet thick. The lower sandstone member is probably a near-shore deposit of a transgressing sea; the basal part of the sandstone commonly fills topographic depressions on an underlying erosion surface. 
The middle shale member is probably an offshore marine deposit, and the upper sandstone member is probably a regressive near-shore marine and brackish-water deposit. In the Livingston area the upper sandstone member is commonly nonresistant, and for geologic mapping purposes the Thermopolis and overlying Mowiry Shales were undifferentiated (Roberts, 1964ah). The Thermopolis-Mowry unit generally is unexposed between the ridges formed by the Kootenai and Frontier Formations.

\section{LITHOLOGIC COMPOSITION}

The Thermopolis Shale in the Livingston area consists of three members (refer to measured section 4). The lower sandstone member consists of thin- to thickbedded, crossbedded, yellowish-gray, fine- to mediumgrained sandstone. The sandstone is composed of well- sorted subrounded grains of quartz and chert and a few grains of magnetite and muscovite. It commonly is irregularly cemented with silica or calcium carbonate. Unequal resistance to weathering of the irregularly or partly cemented sandstone results in raised fretworks on the bedding surfaces on the south flank of Canyon Mountain (figs. 7, 8).

Some beds in the lower sandstone member are quartzose sand. Commonly in local areas of tight folding these sandstone beds have become well indurated and form prominent quartzite ridges. The lower member also contains some interbeds of siltstone that have abundant tracks and trails ascribed to marine bottomdwelling organisms.

The middle shale member is dominantly shale interbedded with very fine grained sandstone, siltstone, claystone, and bentonite. This member at Livingston is dark

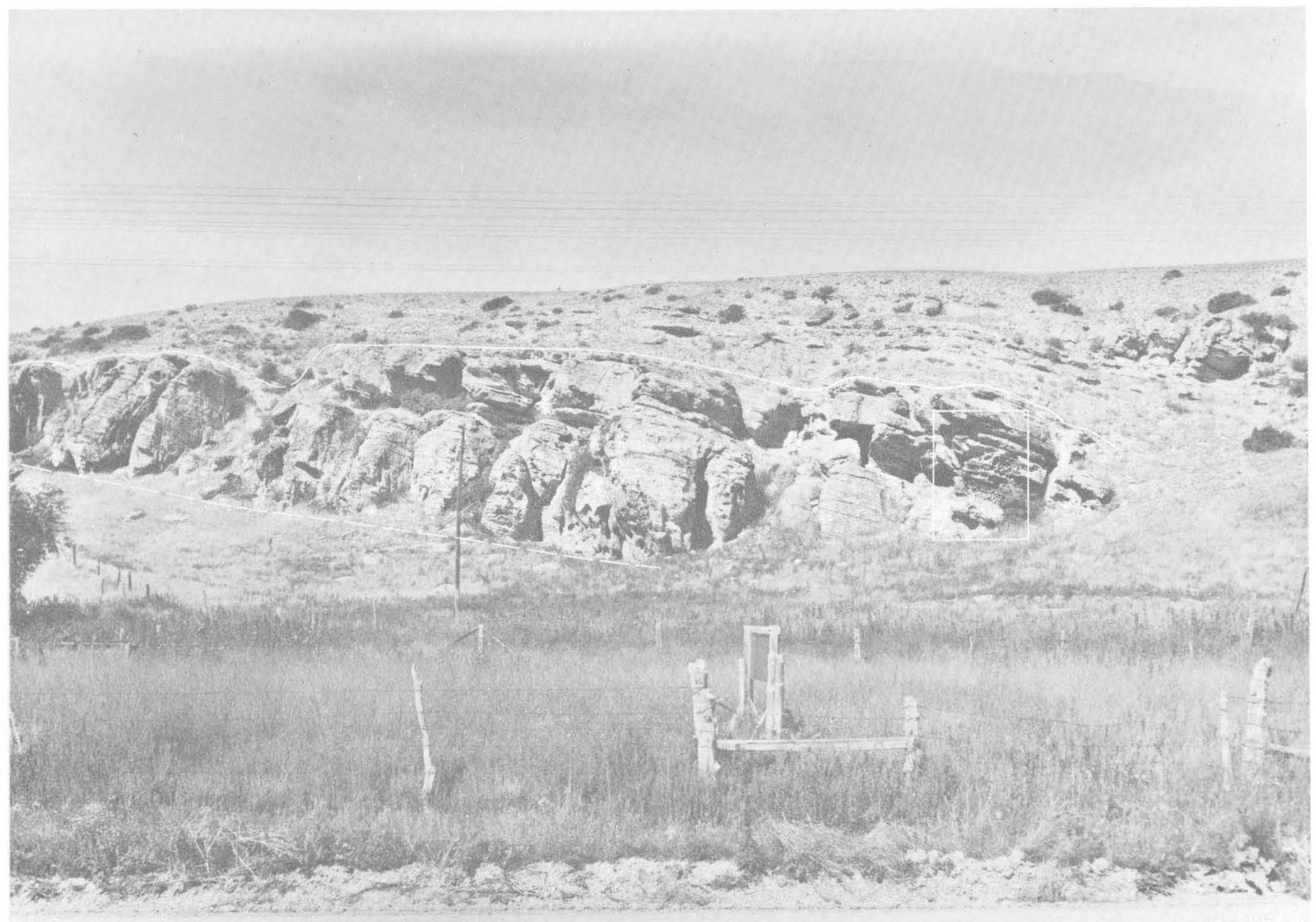

Figure 7.-Excellent exposure of the lower sandstone member of the Thermopolis Shale, NE1/4 sec. 28 , T. 3 S., R. 4 E. Outlined area enlarged in figure 8. 


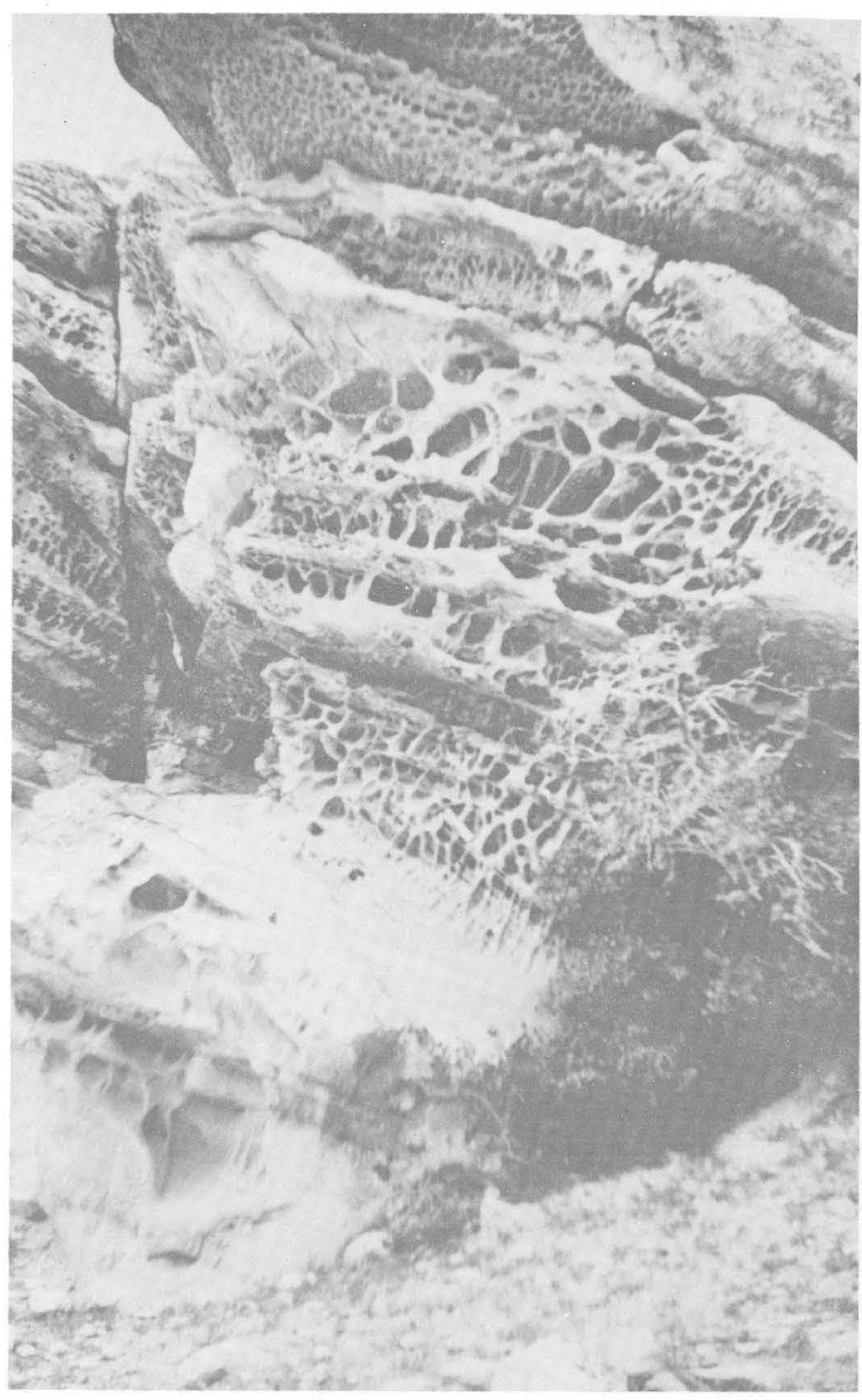

Figure 8.-Fretwork, which is on a cliff of crossbedded sandstone of the Thermopolis Shale, is caused by unequal resistance to weathering of the irregularly cemented sand grains. Enlarged view of part of figure 7 .

gray and weathers to light gray, whereas the overlying Mowry Shale is dark grayish brown and weathers to grayish yellow green and yellowish gray. The shale is carbonaceous, commonly contains macerated plant fragments, and is commonly calcareous. Sandstones interbedded in the middle shale member are thin bedded, very fine grained, silty, calcareous, and commonly contain plant fragments. Most sandstone bedding surfaces are covered with marine worm trails, groove casts, and other sole marks of undetermined origin.

The upper sandstone member consists of mediumto thick-bedded, crossbedded, medium-gray, fine- to very fine grained (table 1), well-sorted, calcareous sandstone. The sandstones are micaceous, glauconitic, and feldspathic, and they contain a limited heavy-mineral suite of magnetite, pyrite, and biotite. A few sandstone beds contain claystone pebbles. Some large plant fragments and carbonaceous trash were noted on bedding surfaces. Bedding surfaces are commonly ripple marked, and many have worm(?) trails and groove and small flute casts.

\section{AGE AND GORRELATION}

In the rorthern part of the Gallatin Range and to the southeast in Wyoming the Thermopolis Shale consists of three members: a lower sandstone member, correlative with the "Rusty beds" and Greybull Sandstone Member of north-central Wyoming; a middle shale member, correlative with the Skull Creek Shale of northeastern Wyoming; and an upper sandstone member correlative with the Muddy Sandstone Member in central Wyoming (fig. 2).

The lower sandstone member correlates with the "First Cat Creek Sand" in central Montana and is in the stratigraphic position of the Fall River Formation of the Black Hills area (Cobban, 1951, p. 2173-2175); however, between central Montana and the Black Hills this interval of rock changes to a silt or shale facies. The Birdhead Sandstone Member of the Thermopolis Shale as used by Thom, Hall, Wegemann, and Moulton $(1935$, p. 47) southeast of Billings, Mont., and the lower sandstone member at Livingston have similar mineralogy and clay-pebble constituents and are presumed to be stratigraphic equivalents. The upper sandstone member is also in about the same stratigraphic position as the Newcastle Sandstone of the Black Hills area but the sand facies is discontinuous between the two areas.

The hiatus between the Kootenai Formation and the Thermopolis Shale is presumed to be short inasmuch as the index fossil Protelliptio douglassi occurs immediately above and below the widespread disconformity that separates the two formations. Stanton (1903, p. 195) and Yen (1951, p. 3) identified this fossil from beds near the top of the Kootenai Formation in southcentral Montana, near Harlowton. Cobban (in Waagé, 1959$, p. 63,72$)$ identified this fossil from the basal bed of the Fall River Formation in northeastern Wyoming, near Devils Tower. Waagé (1959, p. 52-55) referred to this stratigraphic break as a transgressive disconformity and discussed its different features at various localities in the Black Hills. Waagé (1955, p. 47-48) had previously discussed a stratigraphically similar disconformity along the northern Front Range in Colorado. In the Bighorn Basin, Eicher (1960, p. 15) and Moberly (1960, p. 1155) believe that this same disconformity is present at the top of the Cloverly Formation. The evidence thus indicates that the disconformity apparently extends over much of Montana, Wyoming, and Colorado. 
TABLE 1.-Grain-size distribution and heavy-mineral content in sandstones of the Thermopolis Shale, Frontier Formation, Cody Shale, Telegraph Creek Furmation, and Eagle Sandstone near Livingston, Mont.

[All data, in percent; indicated diameter, in millimeters. Tr., trace; N.d., not determined. Analyses, by R. F. Gantnier]

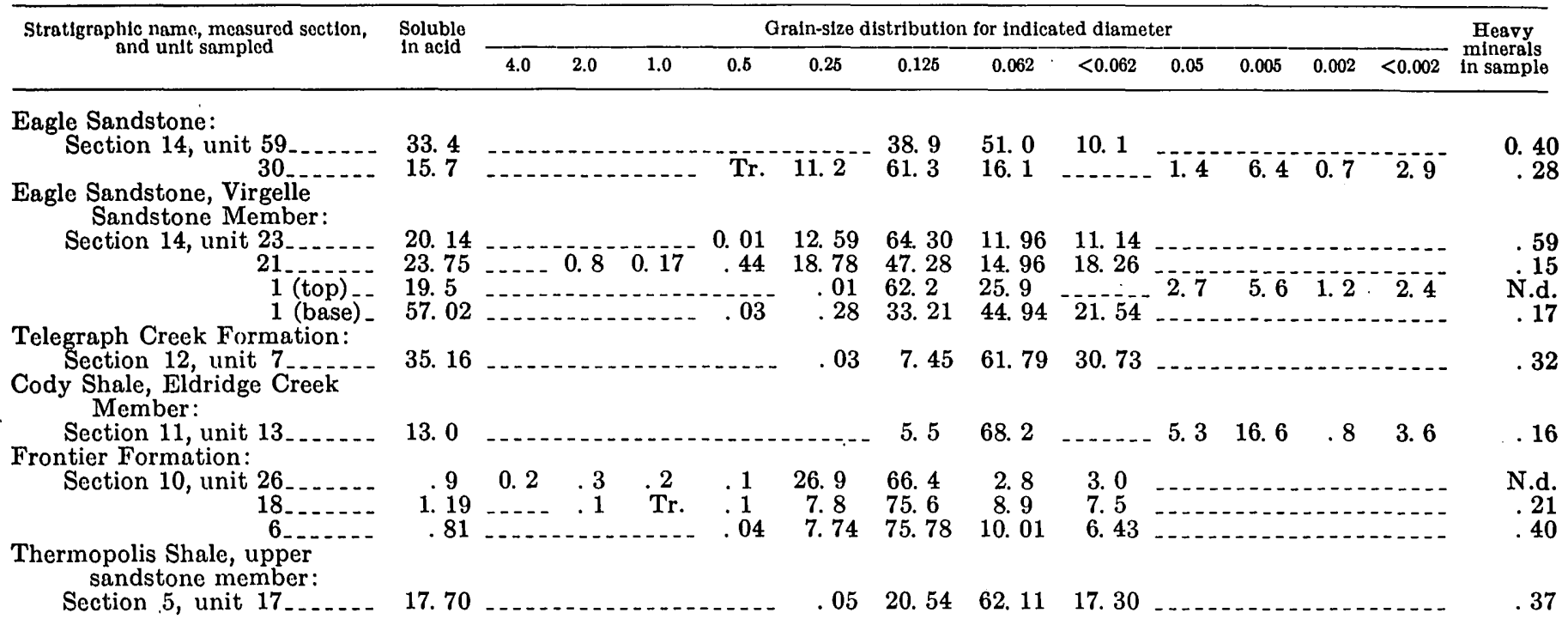

A fairly complete succession of plant microfossils from measured stratigraphic section 4 of the middle shale and upper sandstone members of the Thermopolis Shale and from measured section 7 of the lower Mowry Shale of the Livingston area is listed in table 2. Photographs of these assemblages are given in Tschudy and Veach (1965). R. H. Tschudy (written commun., 1965) made the following generalizations pertaining to this faunal succession:

1. The $\mathrm{S}_{1}-\mathrm{p}$ group $\left(\mathrm{S}_{1}-\mathrm{p} 13, \mathrm{~S}_{1}-\mathrm{p} 14\right.$, and $\left.\mathrm{S}_{1}-\mathrm{p} 15\right)$ characterizes the lower Thermopolis Shale samples.

2. Only one species of angiosperm tricolpate pollen is present in the composited lower Thermopolis sample from U.S. Geological Survey (USGS) Paleobotany localities D3512-A, B, C, and D; the number of species of this pollen type increases in the sample from USGS Paleobotany locality D3512-H.

3. Few angiosperm pollen were found, and all species found belong to the tricolpate group. This finding agrees with information from other parts of the world that unequivocal angiosperm pollen first appeared in the Albian, and there only as tricolpate pollen. No evolutionarily more advanced forms are known from the Albian.

4. In samples from USGS Paleobotany localities D3512-N and U large spores are dominant, particularly species of Cicatricosisporites and $A p$ pendicisporites.

5. The easily recognized and distinctive species of cf. Trilobosporites (TT-rt11) is absent from the Thermopolis, but common in the Mowry samples.
Samples from the Skull Creek Shale on the east side of the Bighorn Mountains, measured section 6 (USGS Paleobotany locs. D3842-A, B), yielded a diagnostic pollen and spore flora (table 3) according to R. H. Tschudy (written commun., 1967). He found that samples from localities D3842-A (42 feet above the base of the Skull Creek Shale) and D3842-B (58 feet above the base of the Skull Creek Shale) contained eight species of monosulcate pollen and two species of tricolpate pollen. This assemblage suggests a correlation with locality D3512-H (167 feet above the base of the Thermopolis Shale at the Livingston reference section 4, unit 18). The number of monosulcate pollen species found decreases with decreasing age in this part of the section.

Few macrofossils have been reported from the middle shale member or its equivalent Skull Creek Shale, and none was collected in the Livingston area during the present investigation. Cobban (1951, p. 2176) listed an Early Cretaceous (Albian) marine fauna collected in central Montana from equivalent black shales assigned to the Colorado Shale.

\section{MOWRY SHALE}

Darton (1904, p. 400) named the "Mowrie beds" from exposures of marine shale on Mowrie Creek northwest of Buffalo, Wyo., in the northern end of the Bighorn Mountains. Mowry has been the approved spelling since 1906 (Darton, 1906, p. 53). Darton and O'Harra (1909, p. 4), in their brief description of the Cretaceous section in the Belle Fourche quadrangle in the Black Hills, S. Dak., considered the Mowry to be a member in the Graneros Shale of the Benton Group of Late Cretaceous 
TABLE 2.-Checklist of plant and miscellaneous microfossils from the Thermopolis and lower Mowry Shales near Livingston, Mont [Identifications by R. H. Tschudy]

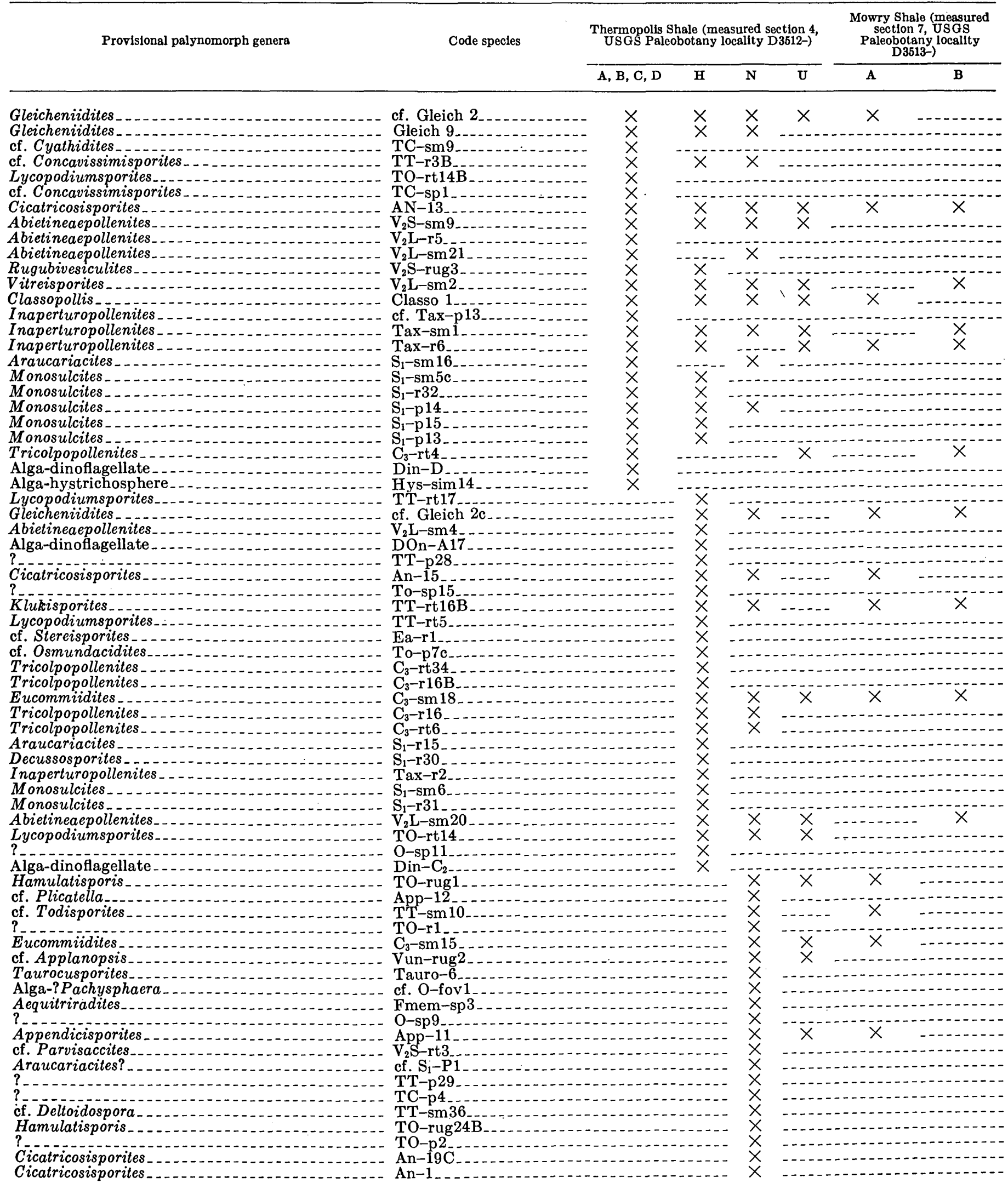


TABLE 2.-Checklist of plant and miscellaneous microfossils from the Thermopolis and lower Mowry Shales near Livingston, Mont.-Con.

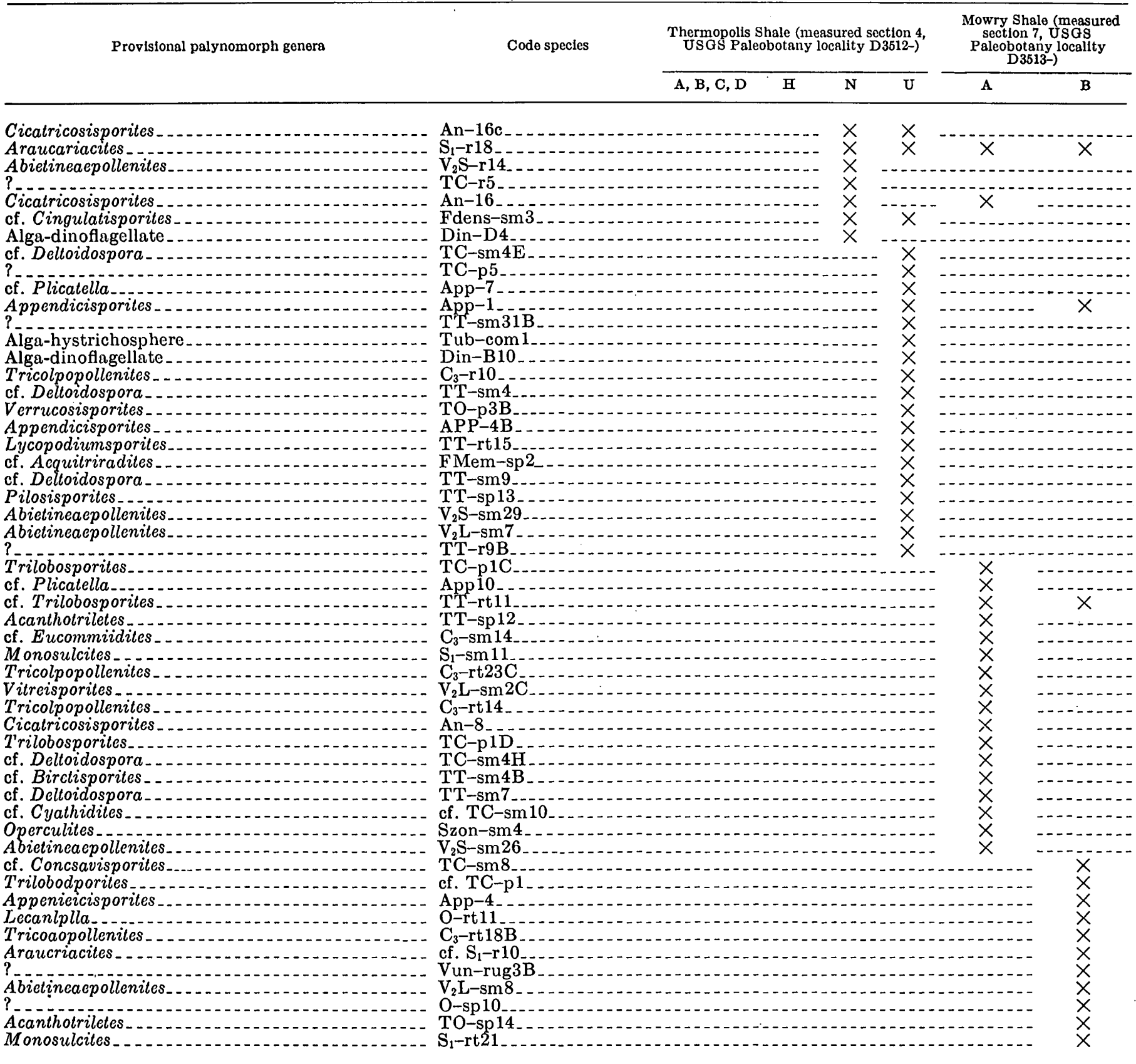

age. In the westein Black Hills of Wyoming, Hancock (1920, p. 39) similarly placed the-Mowry as a member in the Graneros Shale, but of the Colorado Group. Collier (1922, p. 76) separated the basal 25-50 feet of the Mowry Member of the Graneros Shale and designated these soft, dark-shale beds and thin sandy lenses as the Nefsy Shale Member of the Graneros. Rubey (1931, p. 4), in discussing the lithologies of Upper Cretaceous formations in northeastern Wyoming and southeastern Montana, used the name Mowry Siliceous Shale Member of the Graneros Shale, which included beds equivalent to the Nefsy. The Mowry Shale was considered of formation rank by Reeside (1944) in his study of Cretaceous deposits in the western interior of the United States, and many later geologists agreed with this rank. For a comprehensive historical treatment of the application of the name Mowry, the reader is referred to Reeside and Cobban (1960). 
TABLE 3,-Checklist of plant and miscellaneous microfossils from the Skull Creek Shale and Mowry Shale reference section near Buffalo, Wyo. [Identifications by R. H. Tschudy]

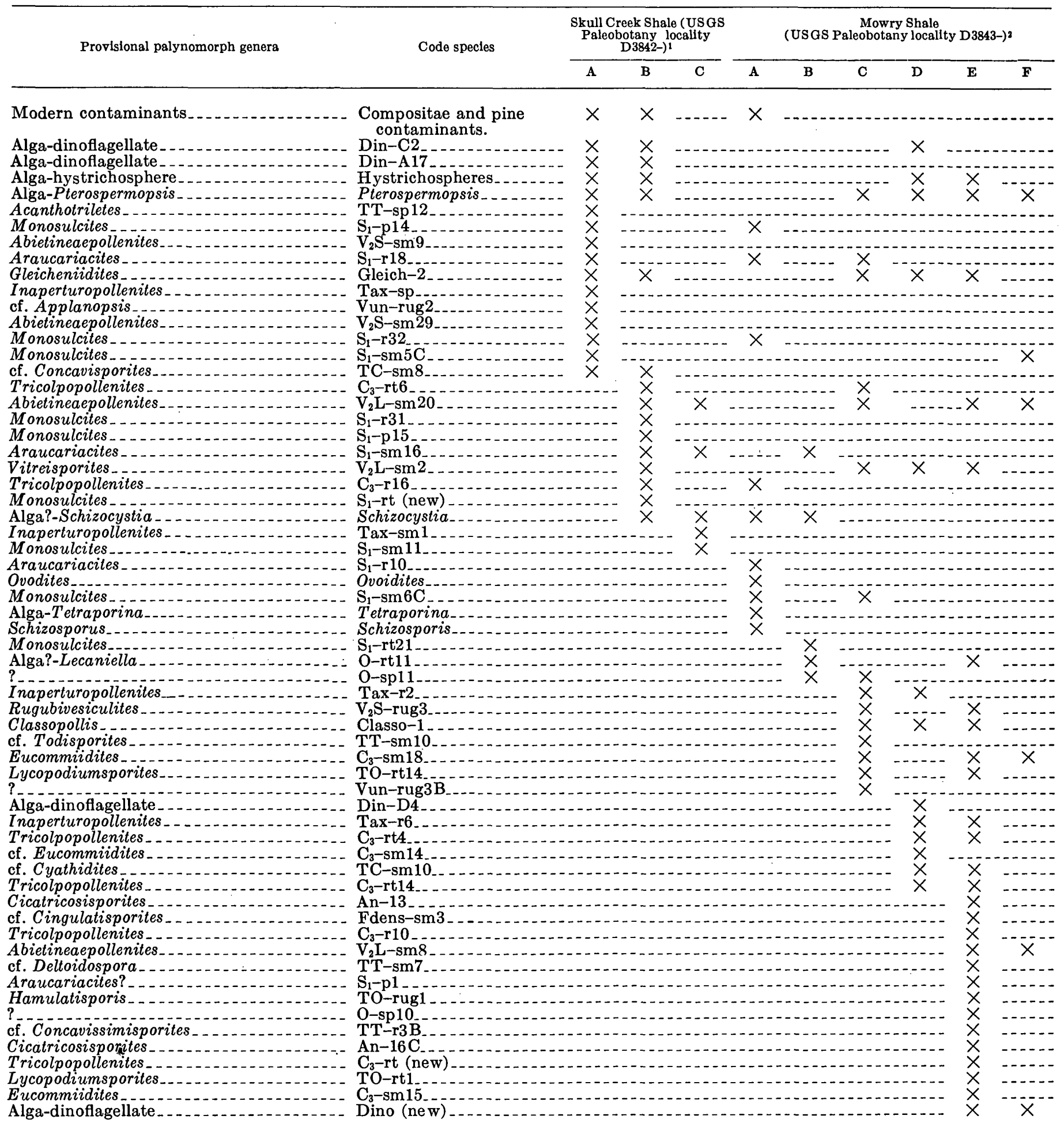

1 For measured section refer to Mapel (1959, p. 39) and measured section 6 of the present report; A, $42 \mathrm{ft}$ above base of Skull Creek Shale; B, $58 \mathrm{ft}$ above base of Skull Creek Shale; and C, $144 \mathrm{ft}$ above base of Skull Creek Shale. base of Mowry Shale; E, $476 \mathrm{ft}$ above base of Mowry Shale; and F, $510 \mathrm{ft}$ above base of Mowry Shale. 
Mapel (1959, p. 42) measured and described the Mowry Shale $1 \frac{1}{2}$ miles south of Darton's undescribed section, and Mapel's section is herein designated the typical section for the Mowry. Mapel included 202 feet of grayish-black shale and interbedded bentonite as the basal "black shale member" that was earlier part of the Thermopolis Shale (refer to discussion under general features of the Thermopolis Shale in this report).

The Mowry Shale is characteristically siliceous, and, according to Rubey (1929), the silica owes its origin to the alteration of volcanic ash. Reeside (1957, p. 517) indicated that the thin and regular bedding of the Mowry Shale suggests deposition in quiet and perhaps deep water. Rubey $(1929$, p. 156, 168) suggested extremely slow deposition on the basis of the large amount of organic material and the widespread abundance of fish scales and other chemically resistant parts of fish, in contrast with the relative scarcity of shells and bones.

The Mowry Shale in the Livingston area conformably overlies the upper sandstone member of the Thermopolis Shale, and it ranges in thickness from 430 to 500 feet. Near Buffalo, Wyo., the Mowry typical section is 527 feet thick (Mapel, 1959, p. 42). Near Thermopolis, Wyo., the Mowry is 560 feet thick (Keefer and Troyer, 1964, p. 18). At the north end of the Pryor Mountains, Mont., the Mowry is 495 feet thick. Near Great Falls, Mont., the stratigraphic equivalent of the Mowry is 330 feet thick (Cobban and others, 1959, p. 2793).

\section{LITHOLOGIC COMPOSITION}

The Mowry Shale in the Livingston area consists of thin-bedded to massive, silty, micaceous, dark-gray to dark-brown shale and mudstone that contain scattered interbeds of sandstone, siltstone, claystone, and bentonite. The shale is tuffaceous and readily weathers to clay. The sandstones are very fine to coarse grained, are poorly sorted, contain much silt in the matrix, and are generally calcareous or siliceous.

Two measured sections $(7,8)$ of the Mowry Shale are about 15 miles apart and are remarkably different. The entire sequence at Rocky Creek Canyon is dominantly tuffaceous; it contains very carbonaceous beds, which bear large plant fragments and thin streaks of coal that suggest deposition in quiet brackish water. On the north flank of Canyon Mountain, the formation is dominantly massive-bedded mudstone and silty shale that is micaceous, pyritic, and generally glauconitic; these rocks suggest shallow restricted marine deposition. The section at Rocky Creek Canyon is 25 percent sand, whereas the section at Canyon Mountain is only 5 percent sand.

In the Livingston area, the Mowry Shale can generally be distinguished from the Thermopolis Shale on the basis of lithology, weathering characteristics, and color. The Thermopolis is dominantly fissile, and the Mowry is dominantly nonfissile. Also, the Thermopolis Shale is dark gray, weathers to light gray, and is not very tuffaceous; whereas, the Mowry Shale is brownish gray, weathers to yellowish gray, and is very tuffaceous. Porcelanitic sandstones are present in the upper 200 feet of the Mowry.

\section{AGE AND CORRELATION}

Before 1951, most workers considered the Mowry Shale to be Late Cretaceous in age. Cobban and Reeside (1951) first assigned the Mowry Shale of the western flanks of the Black Hills and Mowry equivalents in Colorado, Montana, and Wyoming to the Early Cretaceous. On the basis of ammonites, they indicated that the age of the Mowry was late Albian (as shown in fig. 2).

Nine samples from measured sections 6 and 9 (the Skull Creek Shale and the Mowry Shale typical section near Buffalo, Wyo.) were collected to obtain pollen floras for comparison with floras from the Thermopolis and Mowry Shales near Livingston, Mont. The Wyoming samples (table 3), with exception of those from USGS Paleobotany localities D3842-A, D3842-B, and D3843-E, contained corroded assemblages that had few pollen or spores but many marine forms such as hystrichospheres, dinoflagellates, or Pterospermopsis; all the samples lacked the large spores so characteristic of samples of the Thermopolis and Mowry near Livingston (table 2). These facts suggest that the shales at Buffalo, Wyo., were deposited farther from shore under more open water marine conditions than were the equivalent shales at Livingston, Mont.

According to R. H. Tschudy (written commun., 1967), the absence of the larger spores in the Wyoming samples makes direct correlation very difficult. However, when considered as a whole, the fossil assemblages shown on table 3 demonstrate several trends that may be useful. The samples have been plotted in stratigraphic sequence, and changes in fossil content are evident. The most prominent changes are seen if one compares the samples that yielded the best assemblages. The possible correlation of samples from USGS Paleobotany localities D3842-A (42 feet above the base of the Skull Creek Shale) and D3842-B (58 feet above the base) with the sample from USGS Paleobotany locality D3512-H (167 feet above the base of the Livingston Thermopolis Shale reference section) has already been discussed. The number of monosulcate pollen species found decreases with decreasing age in this part of the section. The Mowry Shale samples from Wyoming, particularly those from locality D3843-E, contained a few species found only in the Mowry Shale-namely, 
Vun-rug3B, $\mathrm{V}_{2} \mathrm{~L}-\mathrm{sm} 8, \mathrm{O}-\mathrm{sp} 10, \mathrm{O}-\mathrm{rt11}, \mathrm{TT}-\mathrm{sm} 7$, and $\mathrm{C}_{3}-\mathrm{rt14}$. This assemblage correlates with those (table 2) from the Livingston Mowry section.

\section{UPPER CRETACEOUS SERIES}

The Upper Cretaceous Series in the Livingston area consists of the Frontier Formation, Cody Shale, Telegraph Creek Formation, Eagle Sandstone, Cokedale Formation, Miner Creek Formation, Billman Creek Formation, Hoppers Formation, and the basal part of the Fort Union Formation. These strata are 10,830 feet thick and are characterized by dark-gray shale interbedded with quartzose siltstone and sandstone. Conglomerates derived from Precambrian metamorphic, Paleozoic and Mesozoic sedimentary, and Cretaceous volcanic rocks occur, in addition, in the upper part.

\section{FRONTIER FORMATION}

The Mowry Shale (Lower Cretaceous) is overlain with apparent conformity by a sequence of conglomerate, sandstone, siltstone, and shale that contains thin interbeds of carbonaceous shale and coal. These strata are assigned to the Frontier Formation of Late Cretaceous age. The boundary between the Mowry Shale and Frontier Formation in the Livingston area is the base of the lowest well-defined sandstone of the Boulder River Sandstone Member of the Frontier (Roberts, 1965). The top of the Frontier Formation is placed at the top of the uppermost thick sandstone unit. In this area, the Frontier Formation is conformably overlain by the Cody Shale.

Knight (1902, p. 721) named and described the Frontier Formation from exposures near Kemmerer in southwestern Wyoming. Subsequent workers have assigned the name Frontier to equivalent or partly equivalent beds in Wyoming and adjacent States. For a comprehensive review of the nomenclatural history of the Frontier before 1952, the reader is referred to Cobban and Reeside (1952a). They include a detailed section of the type Frontier in Cumberland Gap near Kemmerer and make lithologic and faunal comparisons of the type section with Frontier sections in nearby areas of Colorado, Montana, Utah, and Wyoming.

Hintze (1915) proposed the names Peay Sandstone and Torchlight Sandstone for prominent sandstone units in the Colorado Formation in a part of the Bighorn Basin of northern Wyoming. Lupton (1916) assigned the sequence in the Bighorn Basin that includes these two sandstone units and the intervening shale to the Frontier Formation and retained Hintze's Peay and Torchlight Sandstones as members. Knappen and Moulton (1931, p. 32-33) applied the formation and member names that were established by Lupton to correlative rocks in the Bridger area of southern Montana. Cobban and Reeside (1952a) extended the use of the name Frontier westward to Columbus, Mont.; Garbarini (1957) continued the correlation westward to McLeod, Mont.; and Roberts (1965) extended the use of the name farther west into the area near Livingston, Mont.

East of the Livingston area, Richards (1957, p. 415) named a prominent 100 -foot-thick sandstone unit exposed along the west side of the Boulder River valley near McLeod, Mont., the Boulder River Sandstone Member of the Colorado Shale. This unit represents the basal part of the Frontier Formation of McLeod, Mont., and adjacent areas and was redesignated as the basal member of the Frontier Formation by Roberts (1965, p. B58).

Thickness of the Frontier Formation in south western Montana seems uniform on the basis of a few control points. At Livingston the thickness is 415 feet; to the south at Gardiner, Mont., the thickness is 416 feet (Brown, 1957, p. 89) ; and to the east at Bridger, Mont., the thickness is 418 feet (Knappen and Moulton, 1931, p. 33).

\section{LITHOLOGIC COMPOSITION}

The Frontier Formation near Livingston is divided into two general lithologic units-a basal series of wellindurated sandstone in the Boulder River Sandstone Member, and less well-indurated sequence of shale, siltstone, and sandstone in the overlying part of the formation. The basal sandstone forms ridges along the flanks of the major anticlines south of Livingston, opposite the north end of the Gallatin Range. The overlying sequence is not generally exposed, except in the beds of a few consequent intermittent streams.

The lithology and other physical characteristics of the Frontier Formation are presented in measured section 10. The Boulder River Sandstone Member is a sequence of light- to dark-gray to grayish-green, poorly sorted, very fine grained to conglomeratic sandstone that contains fairly abundant heavy minerals, lithic chert, glauconite, and rounded gray or brown chert pebbles. The sandstone is commonly cemented by a calcareous matrix of silt or clay. The beds are thin to massive and locally crossbedded (fig. 9). Thickness of the Boulder River Sandstone Member is uniform in the Livingston area and ranges from 115 to 120 feet.

The upper part of the Frontier Formation in the Livingston area consists of 300 feet of sandstone and shale or siltstone in alternating beds. The sandstone is generally calcite cemented and forms low ridges. The siltstone and shale are commonly carbonaceous and locally contain very thin beds of coal. Sandstone beds are thin to massive, and the sandstone is gray to greenish gray, glauconitic, and fairly well sorted to poorly sorted. The 


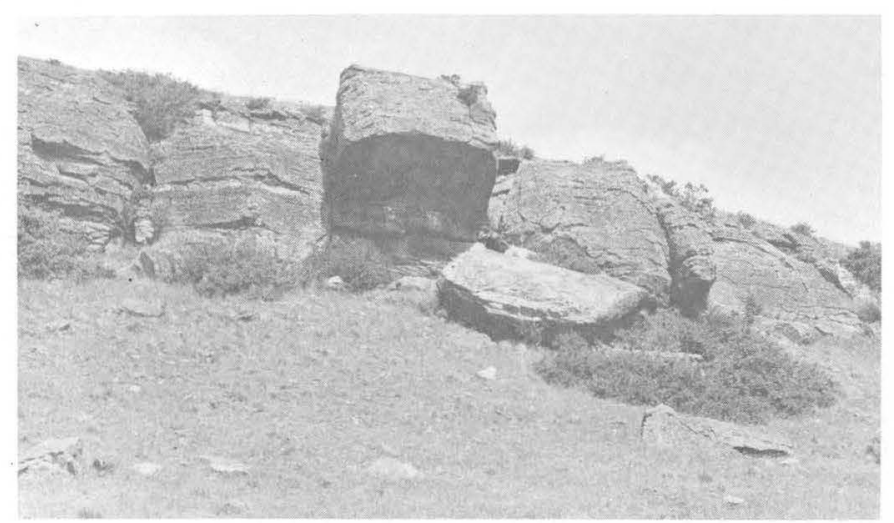

Figure 9.-Prominent 10-foot-thick sandstone unit 32 feet above the base of the Boulder River Sandstone Member of the Frontier Formation, exposed in the $\mathrm{SE}^{1} / 4$ sec. 27 , T. 2 S., R. 9 E. Unit contains abundant chert pebbles typical of the Frontier Formation.

sand grains are mostly quartz, andesine-feldspar, and chert. Heavy minerals include magnetite, zircon, biotite, muscovite, hormblende, anatase, epidote, sphene, sillimanite, staurolite, tourmaline, corundum, garnet, and topaz. Grain-size distribution in the sandstones is domimantly $0.25 \mathrm{~mm}$ to $<0.062 \mathrm{~mm}$ as shown on table 1 and is similar to sandstones in the Virgelle Sandstone Member of the Eagle Sandstone.

A conglomerate bed 300 feet above the base of the Frontier, mapped as "C" bed southwest of Livingston by Roberts $(1964 b ; 1964 \mathrm{e} ; 1964 \mathrm{f})$, is a persistent lag deposit that consists of pebbly sandstone in local shallow channels. The unit is thickest and most conglomeratic in the Chimney Rock quadrangle on the north flank of Antelope Butte (Roberts, 1964b). The conglomerate generally contains well-rounded chert pebbles less than 2 inches in diameter in a sand matrix. Garbarini (1957, p. 98) noted a similar chert-pebble conglomerate 300 feet above the base of the Frontier at McLeod, Mont., and L. W. McGrew (oral commun., 1968) found a similar chert-pebble conglomerate in the Frontier near Ringling, Mont. Sandstone units at the top of the Frontier Formation in the northwestern part of the Wind River Basin, Wyo., contain numerous black and brown chert pebbles (Keefer, 1957, p. 184).

Many fine-grained sandstone units in the Frontier contain silt and (or) clay that has been extensively reworked by bottom-dwelling organisms. Casts of Ophiomorpha (Halymenites) in sandstone beds of the Boulder River Sandstone Member are common (fig. 10). Ripplemarked surfaces and crossbedding are also conspicuous in beds of the Boulder River Sandstone Member.

Porcelanite beds, commonly present in the Frontier Formation in other parts of Montana and Wyoming, are absent near Livingston, although a 45-foot-thick sandstone unit at the top of the Boulder River Sandstone Member has some resemblance to porcelanite (measured section 10, unit 6). The rock is mottled dark gray and medium light gray; it is very fine grained, feldspathic, and micaceous and contains some heavy minerals. Mottling, resembling porcelanite texture, is due to crystallization clusters of analcime in the cementing material. Weathered surfaces have a knobby conglomeratic appearance caused by the erosion of less resistant material between the clusters of analcime (fig. 10). This distinctive surface texture makes this unit an excellent marker bed. It was mapped as the "A" bed by Roberts (1964b, d-f, h).

Bentonites are common in the Frontier Formation in parts of south-central Montana and northwestern Wyoming; however, none were observed in the Frontier near Livingston. This is probably because the strand line was near Livingston during Frontier time, and the volcanic ash that elsewhere formed bentonite was
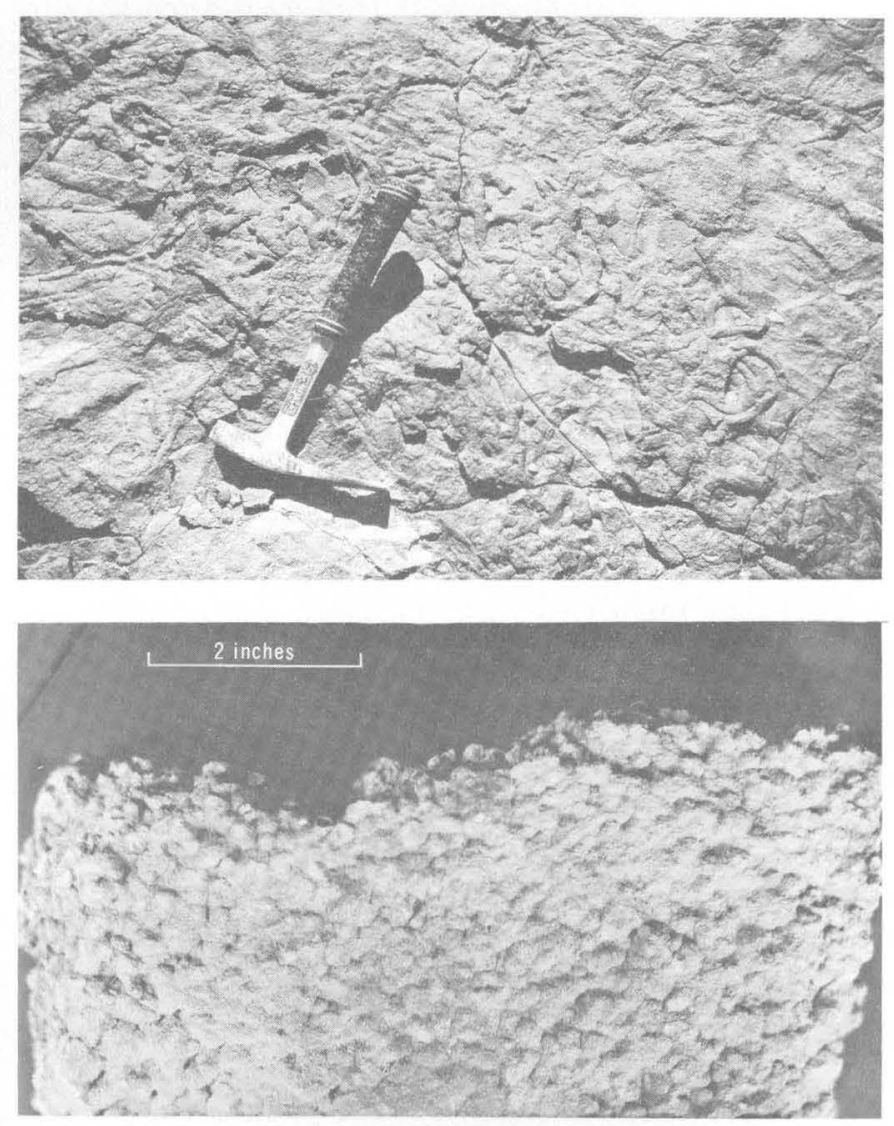

Figure 10.-Boulder River Sandstone Member of the Frontier Formation in the SE $1 / 4$ sec. 27 , T. 2 S., R. 9 E. Upper: Casts of Ophiomorpha and other burrows on a bedding surface near the base of the member. Lower: Analcime-bearing sandstone in the upper part of the member; conglomeratic appearance caused by weathering of less resistant material between clusters of analcime in the cement. 
dispersed in the high-energy near-shore or beach environment. Many of the sandstone units, however, contain zeolite minerals as a part of the cementing matrix. Bradley (1930, p. 4-6 and Slaughter and Earley (1965, p. 70) identified the zeolite minerals in the FrontierMowry sequence in parts of Wyoming as alteration products of volcanic ash.

Sediments of the Frontier Formation in the Livingston area were deposited in shallow, brackish water in an oscillating but generally regressing Late Cretaceous sea. Alternating fine- and coarse-grained units, lenticularity of beds, rapid lithofacies changes, a high carbonaceous content including very thin coal beds, and the spore and pollen floras suggest this interpretation. The sudden deposition in much of Montana and western Wyoming of coarse sand and pebbles of the Frontier over the shale of the Mowry suggests an onset of regional uplift, at that time, in the source area for the Cretaceous rocks. The gradual increase in grain size to the west indicates an uplift that may have been centered in western Montana and (or) Idaho. In a comprehensive regional study of bentonites in the Mowry Shale and Frontier Formation, Slaughter and Earley $(1965$, p. 91$) \cdot$ suggested that the airborne ash, which now forms the bentonites, came irom multiple scattered sources in the vicinity of, or just east of, the present Idaho batholith, and that the bentonites may be the product of volcanism accompanying emplacement of the batholith.

Many writers, including Cobban and Reeside (1952a), Knechtel and Patterson (1956, p. 18; 1962, p. 914), Hose (1955, p. 59), Van Houten (1962, p. 225), and Slaughter and Earley (1965), have described bentonite beds in the Frontier Formation in different parts of Montana and Wyoming; near Harlowton and McLeod, however, bentonite beds are absent, and the bentonite may have been altered to siliceous beds, or the volcanic ash may have been destroyed in the high-energy shallow-water depositional environment.

Richards (1957, p. 416) noted that intercalated darkgray shales in a 290 -foot-thick interbedded shale and sandstone unit above the Boulder River Sandstone Member at McLeod are similar to the dark-gray shales of the Mowry. In the Livingston area, however, the shale above the Boulder River Sandstone differs in several ways from shale in the Mowry. The Mowry Shale is generally massively bedded, dark grayish brown, micaceous, pyritic, and interbedded with thin to medium beds of well-sorted glauconitic sandstone. Several of the shale units contain reddish-brown specks of hematite in their upper part. The shale units in the Frontier Formation are generally thin bedded, dark gray to black, silty, very carbonaceous with streaks of coal and are interbedded with thin- to massive-bedded, commonly crossbedded, fine-grained to conglomeratic sandstone. Approximately 10 percent of the Frontier Formation at Livingston contains chert pebbles, and according to Hares (1916, p. 246), Knappen and Moulton (1931, p. 33), Thom, Hall, Wegemann, and Moulton (1935, p. 49), Cobban and Reeside (1952a, p. 1960), Hose (1955, p. 54), Richards $(1955$, p. $49 ; 1957$, p. 416), Van Houten (1962, p. 225), and many others, chert pebbles are typical of the Frontier Formation.

\section{AGE AND CORRELATION}

The lower half of the type Frontier Formation in southwestern Wyoming has not been precisely dated, but it is probably Cenomanian according to Cobban and Reeside (1952a, p. 1913). They dated the top of the formation at its type area as early Niobrara (Coniacian) age. In their regional study of the Frontier, Cobban and Reeside (1952a, p. 1958-1959) demonstrated that the upper part of the formation is progressively older from west to east across Wyoming. The upper beds range in age from early Niobrara at the type locality in southwestern Wyoming to late Carlile and Greenhorn ages in central Wyoming.

The Frontier Formation in the Livingston area contains a few poorly preserved specimens of Inoceramus sp. and many casts of Ophiomorpha and other animal burrowings preserved as sand-filled tubes of a size similar to those of Ophiomorpha, but parallel to the bedding surfaces (fig. 10). In a roadcut along U.S. Highway 10 just south of Livingston, Mont. in the SW1/4 sec. 19, T. 2 S., R. 10 E. (USGS Paleobotany loc. D-1785) a sample collected from the Frontier Formation yielded corroded palynomorphs unidentifiable as to species. The fauna, identified by R. H. Tschudy (written commun., 1962) included the following:

$\begin{array}{ll}\text { Tricolpate pollen } & \text { Trilete fern spores } \\ \text { Triporate pollen } & \text { Cicatricosisporites } \\ \text { Monosulcate pollen } & \text { Monolete fern spores } \\ \text { Taxodiaceous pollen } & \text { Hystrichospheres } \\ \text { Classopollis } & \text { Dinoflagellates } \\ \text { Eucommiidites? } & \text { Pterospermopsis } \\ \text { Bisaccate pollen } & \end{array}$

The presence of the triporate pollen supports the assignment of these rocks to the post-Albian Cretaceous. The marine organisms-hystrichospheres and dinoflagellates-are evidence for marine, or at least brackishwater, deposition. Specimens of Ophiomorpha (Halymenites) (Häntzschel, 1962, p. W251) in Cretriceous sandstones have been interpreted (Brown, 1939, p. 254) as being the burrows of a decapod crustacean that lived in littoral or shallow neritic sandy environ- 
ments similar to those inhabited by the modern crustacean Callianassa major Say (Weimer and Hoyt, 1964).

Bowen (1918, p. 196-197) named a sandstone unit exposed in the northern part of the Crazy Mountains basin the Big Elk Sandstone Member of the Colorado Shale. According to Bowen, the Big Elk Sandstone is 248 feet thick and in the approximate stratigraphic position of the Frontier Formation. Near the type section in the Big Elk dome, southwest of Harlowton, Mont. (pl. 3), Reeside and Cobban (1960, p. 37) collected Neogastroplites maclearni (index fossil for upper faunal zone of the Albian Stage) from the Mowry Shale 30 feet beneath the Big Elk Sandstone Member. Their fossil identification supports Bowen's tentative correlation of the Big Elk Sandstone with the Frontier; however, most succeeding workers have overlooked Bowen's correlation.

East of the Livingston area, near McLeod, Mont., siliceous shale occurs above the Boulder River Sandstone Member; this relation led Richards (1957, p. 415) to suggest that the Boulder River Sandstone may be partly late Albian in age, the same as the upper part of the Mowry. Cobban and Reeside (1952a, p. 1961) use similar reasoning for suggesting that the Big Elk Sandstone may be of Albian age.

It is the opinion of this writer that the Boulder River Sandstone and overlying sandy sequence at McLeod (Richards, 1957, p. 416) is correlative with the Big Elk Sandstone and that both are lithogenetic equivalents of the Frontier Formation as recognized in adjacent areas (fig. 2). The Frontier Formation is older in the Livingston-Shawmut area than it is farther east because of the gradual withdrawal of the sea to the east.

Sandstone in the upper part of the Frontier Formation at Livingston grades eastward in southern Montana to shale. Young $(1951$, p. $36-37)$ proposed to redefine the Frontier south of Hardin, Mont., to include the shale; however, in that area the shale facies was assigned by Thom, Hall, Wegemann, and Moulton (1935, p. 49) to the Carlile Shale and by Richards (1955, p. $49)$ to the lower member of the Cody Shale.

West of Hardin, near Bridger, Mont., the Peay Sandstone Member of the Frontier Formation of Knappen and Moulton (1931, p. 32-33) is probably correlative with part of the Boulder River Sandstone Member. The Torchlight Sandstone Member of the Frontier of Knappen and Moulton (1931, p. 32-33) is probably correlative with the upper part of the Frontier Formation at Livingston. These correlations are based on uniformity of lithology and thickness of the Frontier and on the presence in both areas of the underlying Mowry Shale and the overlying Cody Shale.

\section{CODY SHALE}

In the Livingston area the Cody Shale is a nonresistant sequence between the Frontier and Telegraph Creek Formations. The Cody forms grassy slopes and valleys along the flanks of the major folds in the area. Exposures are generally weathered and discontinuous.

The Cody Shale was named by Lupton (1916, p. 171) for 3,360 feet of shale and sandy shale between the Frontier and Mesaverde Formations near Basin, Wyo. Lupton (1916, p. 171) also referred to the Cody as being similar to a lithologic sequence, 2,150 feet thick, that Hewett (1914, p. 98) briefly described along the Shoshone River at Cody, Wyo. Fox $(1939$, p. 5) later redescribed Hewett's section along the Shoshone River 2 miles east of Cody and urged that it be accepted as the standard section of the Cody Shale because of its location at the town for which it was named and because of its completeness of exposure and its completeness of microfauna, including arenaceous forms of a western sandy facies and calcareous forms of an eastern shaley facies. Fox's (1939, p. 18-22) section is now generally accepted as the standard section by most stratigraphers.

Iddings and Weed (1894) mapped a unit, the Montana Formation, in the Livingston area, which probably includes the Cody Shale and Telegraph Creek Formation of this report. They correlated their Montana Formation with the Fox Hills Sandstone and the Pierre Shale (Iddings and Weed, 1894, p. 2).

The Cody Shale, which conformably overlies the Frontier Formation in the Livingston area, represents a transgressive return to deeper water marine conditions, with the shoreline to the west. The Cody in this area is subdivided into a lower shale member, a middle sandstone member named the Eldridge Creek Member, and an upper shale member (Roberts, 1965, p. B59). The Cody Shale ranges in thickness from 1,285 to 1,375 feet. The Eldridge Creek Member, named by Roberts $(1964 \mathrm{c})$ is a tongue of shallow-water marine sandstone in the middle part of the Cody Shale; it represents a temporary regression of the Cretaceous sea during middle Niobrara time. The type section of the Eldridge Creek is located near the abandoned townsite of Cokedale along Eldridge Creek in the NE $1 / 4$ sec. 27 , T. 2 S., R. 8 E. Eldridge Creek was named for George H. Eldridge, the outstanding pioneer geologist who first studied the coal deposits of this area.

\section{LITHOLOGIC COMPOSITION}

In the Livingston area, the Cody Shale consists chiefly of nonresistant, dark-brownish-gray, partly silty and sandy, marine shale and contains thin interbeds of bentonite and sandstone (refer to measured section 11). Shale constitutes most of the lower part; sandstone, the 
middle part; and shale, siltstone, and sandstone, the upper part.

The lower member, which overlies the Frontier Formation with apparent conformity, is 400 to 590 feet thick and is dark-gray to dark-brown marine shale interbedded with siltstone throughout.

The Eldridge Creek Member is a persistent unit of thin-bedded greenish-gray fine-grained sandstone (fig. $11)$. This member is very glauconitic and widespread in southwestern Montana, and for these reasons it is an excellent marker bed. In the Livingston area the Eldridge Creek Member ranges in thickness from 90 to 120 feet.

Conformably overlying the Eldridge Creek Member is the upper shale member, which consists of 500 to 845 feet of dark-gray to brown marine shale and siltstone interbedded with very fine grained sandstone. The proportion of sandstone gradually increases toward the top of the member, and the member appears to be conformably and gradationally overlain by siltstone and sandstone of the Telegraph Creek Formation.

The Cody Shale is commonly pyritic and glaueonitic, and in the lower shale member there is a persistent zone of calcareous shale (fig. 2). The sandstone is generally greenish gray, thin bedded, silty, glauconitic, and very fine grained (table 1). It is composed mostly of subrounded grains of quartz and contains lesser amounts of glauconite, mica (generally biotite), lithic chert, and a heavy-mineral suite that is dominantly magnetite.

Thickness of the Cody Shale or its stratigraphic equivalents is generally uniform in much of western Montana and northwestern Wyoming. It is 1,285 feet thick at Livingston; 1,272 feet thick at Mount Everts in Yellowstone Park (Fox, 1939, p. 25) ; 1,320 feet thick just west of the Pryor Mountains at Wade, Mont. (Fox, 1939, p. 29) ; and 900-1,200 feet thick in the Great Falls, Mont., area (Cobban and others, 1959, p. 2793). The

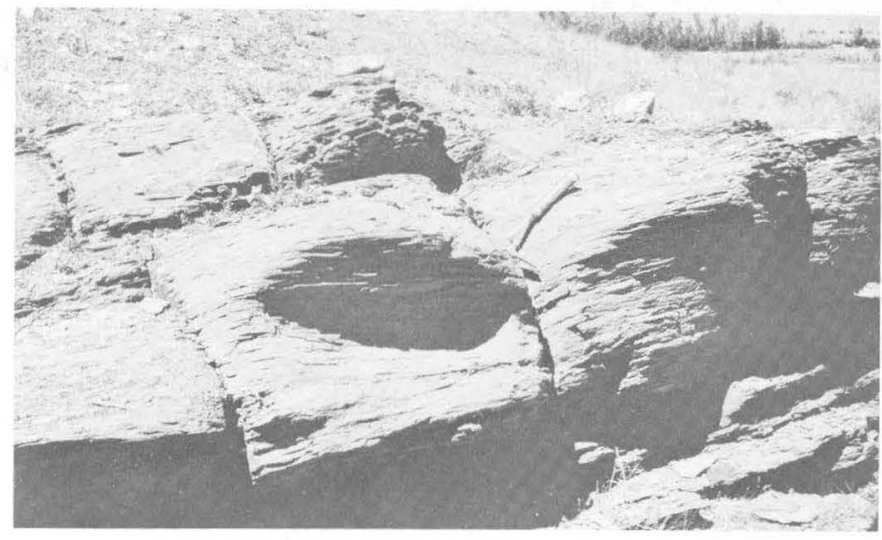

FIGURE 11.-Thin-bedded glauconitic very fine grained sandstone of the Eldridge Creek Member of the Cody Shale in the SE1/4 sec. 27 , T. 2 S., R. 9 E.
Cody thickens markedly to the southeast into the Bighorn Basin, where it is 2,120 feet thick at Cody (Fox, 1939, p. 19) and 3,360 feet thick at Basin, Wyo. (Lupton, 1916, p. 171). Similarly, the Cody increases in thickness from 3,600 feet in the northwestern part of the Wind River Basin to more than 5,000 feet in the southeastern part (Keefer and Rich, 1957, p. 72).

\section{AGE AND CORRELATION}

The lower shale member of the Cody Shale is correlative with the Greenhorn Formation, Carlile Shale, and the lower part of the Niobrara Formation of northeastern Wyoming (fig. 2). A persistent limy shale unit or calcareous zone in the lower part of the lower shale member is correlative with the Greenhorn Calcareous Member of the Cody Shale of south-central Montana and the Cone Calcareous Member of the Marias River Shale of northwestern Montana.

A marine fauna was first collected from the Eldridge Creek Member of the Cody Shale near Livingston by W. M. Davis and identified by R. P. Whitfield (in Eldridge, 1886 , p. 747 ). Whitfield classed the fauna as characteristic of the Fort Benton and Niobrara faunal divisions of the Colorado Group.

The Eldridge Creek Member in the Livingston area contains the following fauna identified by W. A. Cobban (written commun., 1955) :

USGS Mesozoic locality no. D581 (in the $\mathrm{SE}^{1 / 4}$ sec. 27 , T. 2 S., R. 9 E.) ;

Pelecypods :

Pinna sp.

Inoceramus cf. I. involutus Sowerby cf. I. stantoni Sokolow

Ostrea congesta Conrad

Gryphaea sp.

Exogyra sp.

Anomia subquadrata Stanton

Gastropods :

Gyrodes depressa Meek

Turritella sp.

Actaeon propinquus Stanton

Cephalopods :

Baculites asper Morton

Scaphites sp.

Actinocamax n. sp.

USGS Mesozoic locality D1779 (in sec. 14, T. 3 S., R. 7 E.) :

Pelecypods :

Inoceramus cf. I. involutus Sowerby cf. I. stantoni Sokolow

Pteria sp.

Ostrea congesta Conrad

Anomia subquadrata Stanton

Pholadomya papyracea Meek and Hayden

Crassatella sp.

Legumen sp.

Panope sp.

Gastropod :

Gyrodes depressa Meek 
USGS Mesozolc locality D2592 (in sec. 26, T. 3 S., R. 7 E.) :

Pelecypods :

Pinna sp.

Inoceramus cf. I. involutus Sowerby

Pteria cf. P. linguaeformis (Evans and Shumard)

Ostrea congesta Conrad

Exogyra sp.

Anomia subquadrata Stanton

Crassatella andrewsi Henderson

Gastropods :

Gyrodes conradi Meek

Turritella sp.

Cephalopods :

Baculites asper Morton

Scaphites cf. S. depressus Reeside

cf. S. binneyi Reeside

According to W. A. Cobban (written commun., 1955) the fauna is similar to that from the lower part of the Smoky Hill Chalk Member of the Niobrara Formation. The diagnostic short-ranging ammonite, Scaphites depressus, places the Eldridge Creek Member in a limited part of the upper Coniacian (fig. 2). Cobban further commented that the fragmentary condition of the fossils and presence of abundant oysters suggested a shallow-water near-shore marine environment of normal salinity.

W. A. Cobban (written commun., 1957) identified the following fauna collected by G. S. Garbarini from the Eldridge Creek Member near McLeod, Mont., east of Livingston.

USGS Mesozoic locality Di282 (in sec. 8, T. 3 S., R. 13 E.) :

Pelecypods :

Nucula cf. $N$. coloradoensis Stanton

Inoceramus involutus Sowerby

Pteria cf. $P$. linguaeformis (Evans and Shumard)

Exogyra sp.

Pholadomya papyracea Meek and Hayden

Crassatella cf. C. wyomingensis Sidwell

Gastropods :

Gyrodes sp.

Tessarolax hitzii White

Anisomyon sp.

Cephalopods :

Eutrephoceras sp.

Baculites asper Morton

codyensis Reeside

Scaphites tetonensis Cobban

Actinocamax sp.

W. A. Cobban (in Richards, 1957, p. 417) collected and identified the following ammonite of late Niobrara (Santonian) age from the upper shale member of the Cody Shale, approximately 120 feet below the Telegraph Creek Formation-Cody Shale contact, near Livingston.

USGS Mesozoic locality 23026 (in sec. 18, T. 2 S., R. 10 E.) :

Cephalopod:

Clioscaphites choteauensis Cobban

W. A. Cobban (written commun., 1957) identified the following late Niobrara (Santonian) fauna collected by Garbarini (1957, p. 101) from the upper shale member of the Cody Shale, east of Livingston near McLeod, Mont.:

USGS Mesozoic locality D1283 (in sec. 6, T. 3 S., R. 13 E.) : Brachiopod :

Lingula subspatulata Hall and Meek

Pelecypods :

Inoceramus sp.

Ostrea sp.

Pholadomya papyracea Meek and Hayden

Cephalopods :

Baculites codyensis Reeside

Clioscaphites vermiformis (Meel : and Hayden)

Fish scales :

Ichthyodectes sp.

Echidnocephalus? sp.

\section{TELEGRAPH CREEK FORMATION}

The Telegraph Creek Formation is a shallow-water marine siltstone unit transitional between the underlying Cody Shale and the overlying Virgelle Sandstone Member of the Eagle Sandstone.

The Telegraph Creek Formation was named by Thom $(1922$, p. 38$)$ for a marine sequence of sandy shale and calcareous sandstone at the head of Telegraph Creek southeast of Billings, Mont. Concretionary sandstone near the middle of the same sequence in the Bighorn Basin, Wyo., was earlier named the Elk Basin Sandstone Member of the Eagle Sandstone by Hares (1917, p. 429), but later (in Bowen, 1918) he assigned the Elk Basin Sandstone Member to the Telegraph Creek Formation.

Knappen and Moulton (1931, p. 35) extended the name of Telegraph Creek to strata west of Billings, near Park City, Mont.; however, according to W. A. Cobban (oral commun., 1968) they used the Elk Basin Sandstone as the base of their formation, and they placed the lower half of the Telegraph Creek of Hares (in Bowen, 1918) in their Niobrara Shale. Richards $(1955$, p. 57) used the name Telegraph Creek in the type area as a member of the Cody Shale. In the area southeast of Livingston, Richards (1957, p. 417) included equivalent strata in the Colorado Shale.

South of Livingston, Wilson (1934) designated 318 feet of Upper Cretaceous rocks at Gardiner, Mont., as the Telegraph Creek Formation. Near Livingston, Skeels $(1939$, p. 817$)$ assigned 350 feet of sandy shale and sandstone to the Telegraph Creek(?) Formation. At McLeod, Mont., Garbarini (1957, p. 102) measured 370 feet of Telegraph Creek Formation, including a lower resistant unit 94 feet thick and an upper nonresistant unit 276 feet thick.

Weed $(1893$, p. 16,18$)$ referred to the upper 150 feet of the Telegraph Creek Formation at Cokedale, Mont., as the Tombstone Sandstone. At this locality, individual 
thin platy well-indurated sandstone beds dip $45^{\circ}$ into the grassy slopes and weather into forms that resemble rows of tombstones in a cemetery.

The Telegraph Creek Formation consists of thin beds of calcareous sandy siltstone and sandstone and is approximately 275 feet thick at Cokedale, Mont., 9 miles west of Livingston, and 295 feet thick at Livingston (fig. 12):

In the Livingston area the Telegraph Creek Formation is rarely exposed; it generally forms a belt of lightyellowish-gray soil and talus beneath the prominent ridge-forming Virgelle Sandstone Member of the Eagle Sandstone. The formation is usually identified on the basis of lithology and stratigraphic position. The lower and upper contacts of the Telegraph Creek are gradational and are picked arbitrarily in most places. The base of the Telegraph Creek is generally covered by Quaternary deposits; however, in the few localities where it is exposed, the contact with the Cody Shale is placed at the lowermost biotitic sandstone bed (Roberts, 1965, p. B59).

\section{LITHOLOGIC GOMPOSITION}

In general, the Telegraph Creek Formation consists of thin-bedded light-olive-gray siltstone interbedded with fine-grained to very fine grained light-gray calcareous sandstone and dark-gray mudstone and shale. The formation weathers to a distinctive yellowish gray. At Cokedale (measured section 12), the Telegraph Creek Formation is predominantly siltstone and sandstone at a ratio of approximately 3 to 1 . At Livingston the formation (measured section 13) is approximately one-third shale and mudstone and two-thirds siltstone and sandstone. Calcite cements the formation throughout. Sandstones are moderately well sorted and com-

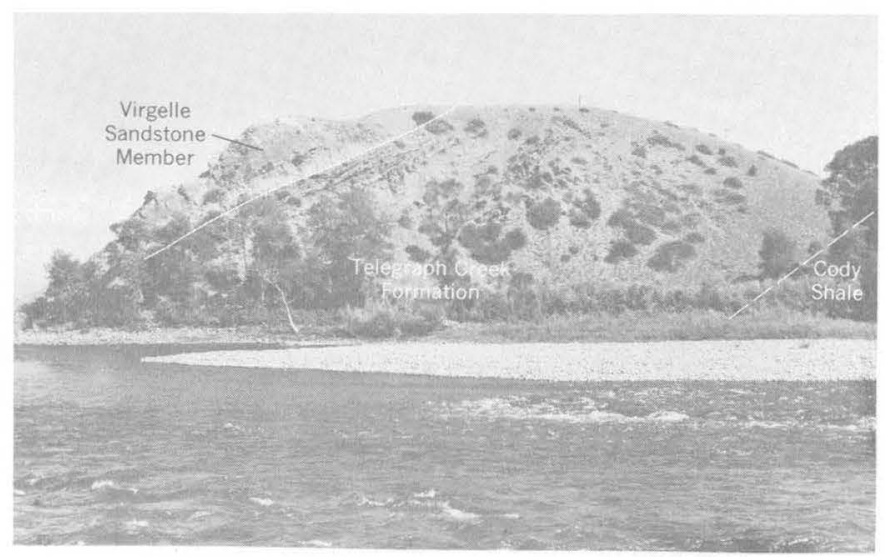

Figure 12.-Telegraph Creek Formation immediately east of Livingston, Mont., on the east bank of the Yeliowstone River in the NE1/4 sec. 18, T. 2 S., R. 10 E. At this locality the Telegraph Creek is a transitional unit between the Cody Shale and the Virgelle Sandstone Member of the Eagle Sandstone. posed of angular to subrounded grains that have a size distribution very similar to that of the upper sandstone member of the Thermopolis Shale (table 1). The sandstones consist predominantly of quartz and contain lesser amounts of potassium feldspar, plagioclase, chert, and some heavier minerals-which (listed approximately in order of decreasing abundance) include magnetite, zircon, tourmaline, biotite, a patite, augite, garnet, and hornblende. The grain size of the sandstone generally increases in coarseness upward from very fine grained or silty in the basal part of the formation to fine grained to medium grained at the top and in the overlying Eagle Sandstone. This transition from very fine grained to medium grained reflects a gradual uplift in the area of the Elkhorn Mountains to the west.

\section{AGE AND CORRELATION}

Thom (1922, p. 38) reported that the fauna from the Telegraph Creek includes species typical of both the Niobrara Shale and the Eagle Sandstone but contains more species of the latter. Reeside (1927) described some cephalopods from the Telegraph Creek and later (in Thom and others, 1935 , p. 54-56) listed a more complete fauna from the formation. According to Reeside the Telegraph Creek contains a mixed Eagle and Niobrara fauna; however, he considered the formation to be the basal part of the Montana Group. Cobban and Reeside (1952a) assigned a Santonian age to the Telegraph Creek, and according to their chart the formation forms the base of the Montana Group.

Differences in defining the Telegraph Creek Formation are due partly to the unit's being transitional between the Cody Shale and the Eagle Sandstone. Sandstones designated as the Elk Basin Sandstone Member in the vicinity of the type Telegraph Creek by various authors are not everywhere the same as the type Elk Basin Sandstone near Elk Basin, Wyo. According to W. A. Cobban (oral commun., 1968) the type Elk Basin Sandstone contains Scaphites hippocrepis, and a different sandstone identified as Elk Basin by Knappen and Moulton (1931) is older and contains Desmoscaphites bassteri. Also, prominent sandstones are known in the Telegraph Creek Formation only in south-central Montana; such marker beds are lacking in the formation in other areas. This problem of defining the Telegraph Creek is further complicated in that the formation becomes older westward and the three units-Cody, Telegraph Creek, and Eagle-become coarser grained in the same direction.

\section{EAGLE SANDSTONE}

The Eagle Sandstone near Livingston, Mont., consists of sandstone, siltstone, rock types intermediate between the two, and coal beds. 
Rocks deposited in the vicinity of Livingston during the latest part of Cretaceous time and in Paleocene time show a gradual upward transition from the marine Telegraph Creek Formation to the brackish-water marine and nonmarine Eagle Sandstone into continental deposits of the Livingston Group and Fort Union Formation. This sequence is a typical regressive relationship in which coarser near-shore and continental sediments were spread seaward over penecontemporaneously deposited finer grained marine sediments. The regional uplift that produced this regression was accompanied by a little volcanic activity as indicated in the Virgelle Sandstone Member of the Eagle by thin. lenticular sandstones derived from andesitic volcanic rocks and near the middle of the Eagle Sandstone by two microlitic tuffs. Volcanic sedimentary rocks make up only a small part of the Eagle, but they are an indication of early volcanic activity to the west, probably in the Elkhorn Mountains near Boulder, Mont.

Weed (1899a, p. 2) named the Eagle Formation from exposures along the Missouri River at the mouth of Eagle Creek in Chouteau County, north-central Montana. At the type locality the formation consists of three lithologic units-an upper unit of light-gray thinbedded sandstone, a middle coal-bearing unit of siltstone and carbonaceous rocks, and a persistent lower unit of hard massive sandstone. The lower sandstone unit was later named the Virgelle Sandstone Member of the Eagle Sandstone by Bowen (in Stebinger, 1914b, p. 62) from exposures along the Missouri River near the town of Virgelle, Mont. Calvert (1908, p. 108) and Stone (1909, p. 78) first used the name Eagle Sandstone for the coal-bearing sandstone and siltstone sequence in central Montana.

Weed $(1893$, p. 11) separated the nonvolcanic coalbearing formation (Eagle Sandstone) from the overlying volcanic-derived sediments of his Livingston Formation (Cokedale Formation of this report) on lithology and stated that the two were separated by an unconformity. Stone and Calvert $(1910$, p. 761) correctly described Weed's Livingston Formation as conformably overlying the coal measures. Roberts (1957, p. $47 ; 1963$, p. B90) arbitrarily assigned the top of an arkosic sandstone that overlies the uppermost minable coal bed (Cokedale No. 5) as the contact between the Cokedale Formation and the underlying Eagle Sandstone.

In the Livingston area strata of the Eagle Sandstone consist of a sequence of lagoonal, estuarine, deltaic, swamp, and beach deposits. These strata interfinger with marine nearshore and offshore deposits that are mainly to the east and with continental deposits, mainly to the west.
The Eagle Sandstone gradationally overlies the Telegraph Creek Formation and is gradationally overlain by the Cokedale Formation. The lithologic difference between the Eagle Sandstone and the Cokedale Formation is a conspicuous flood of andesitic volcanic detritus in the Cokedale.

Near Livingston the thickness of the Eagle Sandstone ranges from 515 to 860 feet and averages about 600 feet. The Eagle Sandstone is best exposed at Cokedale, 9 miles west of Livingston, where it is 645 feet thick, including the 110-foot-thick Virgelle Sandstone Member at its base (measured section 14).

The Eagle Sandstone is about twice as thick at Cokedale as it is a few miles to the north or east. At Loweth, Mont., the Eagle Sandstone is $\mathbf{4 7 0}$ feet thick and at Columbus, Mont., it is 245 feet thick (J. R. Gill, oral commun., 1962). At the southern end of the Bridger Range the Eagle is about 600 feet thick but thins to about 100 feet thick at the northern end of the range (McMannis, 1955, p. 1388, 1407). Thickness of the Eagle Sandstone increases southward from Livingston, and at Mount Everts near Gardiner, Mont., it is 777 feet thick (Fraser and others, 1969, p. 106). West of the Livingston area the Eagle has been truncated (Robinson, 1963, p. 58). Varying thicknesses among localitie; is due to an eastward depositional thinning and to differences among workers in placement of the formation contacts. In north and south-central Montana the Eagle is overlain by marine shale and interbedded sandstone of the Claggett Shale. In areas where the Claggett is present, the top of the Eagle Sandstone is the uppermost nonmarine bed; however, in areas where the Claggett equivalent is nonmarine, the top of the Eagle is generally placed at the lithologic change where volcanic detritus becomes abundant. In some areas near Livingston, coal-bearing rocks in the lower part of the nonmarine Claggett equivalent lie conformably on coal-bearing rocks of the Eagle, making separation of the two formations difficult.

\section{LITHOLOGIC COMPOSITION}

The Eagle Sandstone at Cokedale consists generally of well-bedded to massive, well-indurated, crossbedded sandstone intercalated with beds of coal, carbonaceous siltstone and shale, and tuff or tuffaceous siltstone (measured section 14). All gradations between sandstone and siltstone are found, but sandstone beds predominate. The sandstone is very light gray to yellowish gray and of variable composition and texture-in some localities, massive and coarse grained; in others, banded or laminated and fine grained.

The upper part of the Eagle Sandstone includes an upper carbonaceous unit and a lower sandstone unit 
(fig. 13). The carbonaceous unit, or upper coal zone, consists of coal beds, carbonaceous siltstones, and sandstones. The lower sandstone unit consists of well-bedded to massive, medium- to well-sorted, light-olive-gray, quartzose sandstone and siltstone. The indurated beds are generally calcareous. A mechanical analysis of a representative sandstone sample is shown in table 1 . Sand grains are angular to subangular and have the following distribution: 38.9 percent fine sand, 51.0 percent very fine sand, and 10.1 percent silt and clay. The sample is 33.4 percent carbonate by weight and has a distinctive heavy-mineral suite. The heavy minerals (listed approximately in order of decreasing abundance) are magne ite, zircon, tourmaline, augite, rutile, staurolite, apatite, anatase, muscovite, biotite, corundum (colorless), epidote, and garnet (colorless).

The lower half of the Eagle Sandstone contains two carbonaceous units alternating with two sandstone units. The lowest sandstone unit is the Virgelle Sandstone Member. Above it are the two carbonaceous units and an intervening sandstone unit which constitute the lower coal zone. The carbonaceous units consists of coal, carbonaceous siltstone, and fine-grained sandstone. The medial sandstone unit is hard, massive, light gray, fine grained, calcareous, and quartzose and contains a variety of heavy minerals. Oysters, Inoceramus, and large plant fragments are present in the middle of this unit. This medial sandstone unit lenses out along its strike and is not present east of sec. 26, T. 2 S., R. 8 E., or west of sec. 21 , T. 2 S., R. 8 E. A representative sample from lower in the Eagle contains angular to subrounded grains in the following distribution: trace of coarse sand, 11.2 percent medium sand, 61.3 percent fine sand, 17.5 percent very fine sand, and 10.0 percent silt and clay (table 1). The sample is 15.7 percent carbonate by weight. The heavy minerals (listed approximately in order of decreasing abundance) are magnetite, zircon, tourmaline, garnet (colorless), brookite, rutile, apatite, staurolite, epidote, muscovite, biotite, and corundum (colorless).

The two coal zones in the formation, above the Virgelle Sandstone Member, are persistent throughout the area (Roberts, 1957, p. 43) and contain many commercial-grade coal beds (Roberts, 1957; 1966, p. A24-A29). The coals are high-volatile $\mathrm{A}, \mathrm{B}$, and $\mathrm{C}$ bituminous in rank, some of coking quality. The estimated coal reserves remaining in the Eagle Sandstone in the Livingston coal field, as of January 1965 , totaled more than 300 million short tons (Roberts, 1966, p. A49-A51). These reserves are in beds 14 inches or more thick and within 3.000 feet of the surface.

The Virgelle Sandstone Member is firmly cemented, massive to crossbedded, very light gray, generally fine grained quartzose sandstone. It contains a few channelfill pebble-conglomerate zones, and near its center a few lenticular beds contain fragments of microporphyritic and fine-grained andesite. Locally the uppermost beds of the Virgelle contain 1 percent or more magnetite. The magnetite and other heavy minerals were concentrated in a beach environment during regression of the sea. $\mathbf{A}$ mechanical analysis of the insoluble residue of a representative sample from the middle of the Virgelle indicated that the angular to subrounded (generally subangular) grains have the following Wentworth distribution: 0.08 percent medium sand, 66.67 percent fine sand, 14.96 percent very fine sand, and 18.26 percent silt and clay (table 1 ). The sample is 23.75 percent carbonate by weight. Heavy minerals in the sample (listed approximately in order of decreasing abundance) are magnetite, zircon, tourmaline, muscovite, biotite (green and brown), apatite, diopside, corundum (colorless and red), rutile, staurolite, garnet (pink), hornblende (green), and epidote(?).

Petrographic examination of the Eagle Sandstone indicates that it consists predominantly of quartz (1550 percent) and contains lesser amounts of plagioclase (andesine), potassium feldspar (orthoclase), and rock fragments of fine-grained andesite, microlitic and microporphyritic andesite, quartzite, and chert. Most quartz grains have straight to slightly undulose extinction and a few vacuoles and inclusions, which suggest a plutonic source. Some of the quartz grains, however, have strongly undulose extinction and no inclusions or vacuoles, which suggest a metamorphic source. Other minerals present in thin section are hematite, ilmenite, leucoxene, allanite, chlorite, pyrite, sericite, and clay minerals. Carbonaceous material is abundant. Samples from units 38 and 41 in measured section 14 contain greater than 1 percent pyrite.

Secondary carbonate commonly replaces feldspar and makes it difficult to distinguish between rock fragments and matrix. Carbonate is present as a cement, and silica and zeolite minerals are present in the cement in trace amounts.

Tuffs in the Eagle Sandstone generally consist of a fine-grained matrix or groundmass that contains abundant plagioclase microlites and laths. Numerous cavities are present which are filled with carbonate and silica. Many siltstones in the upper part of the formation contain enough volcanic ash or very fine grained volcanic debris to be termed tuffaceous (measured section 14).

\section{AGE AND CORRELATION}

Fossil leaves collected by members of the Northern Transcontinental Survey from beds presumably in the lower part of the Livingston Group were described by 


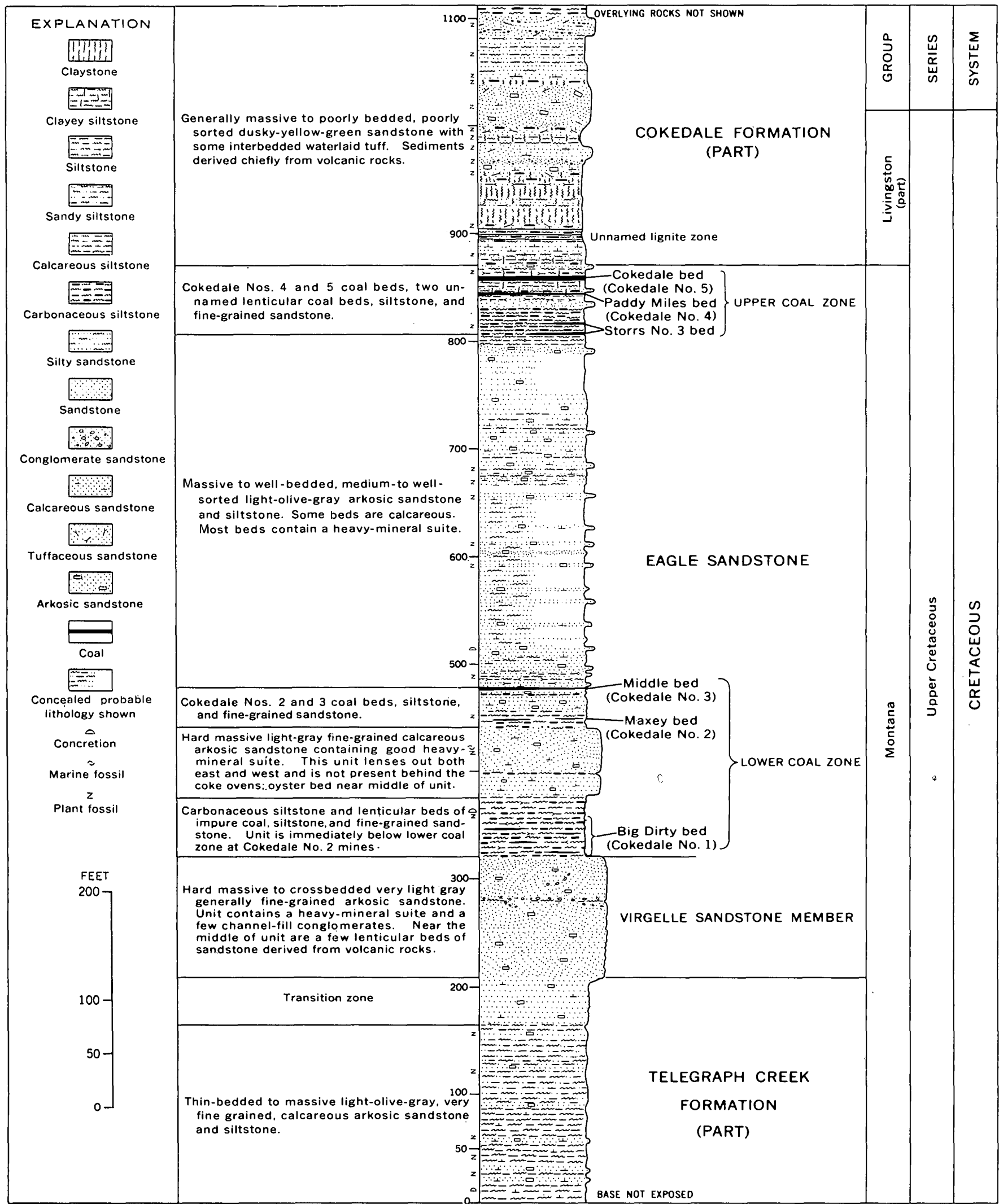

Fraule 13.-Stratigraphic reference section of the Bagle Sandstone in the NW 1/4 sec. 26, T. 2 S., R. 8 E., at Cokedale, Park County, Mont. 
Lesquereux (1873, p. 404-417) and assigned to the early Eocene. Knowlton (1892, p. 153-154) examined this and subsequent collections from other localities in this area, including some collections from the Eagle Sandstone, and designated the entire collection as the fossil flora of the Bozeman coal field of Laramie age. According to Pumpelly (1886, p. 692) the coal-bearing horizon at the Bozeman coal field was "about 3,700 feet above the Jurassic and some distance above fossils of Benton or Niobrara age and yet so low in the Cretaceous column as to be apparently below the Laramie." Davis (1886, p. 698) stated, on the basis of paleontological studies by R. P. Whitfield, that "the horizon of workable coals near the Muir tumnel (Bozeman Pass-5 miles west of Cokedale) is without question lower than the Laramie Formation to which the lignitic coals of the Rocky Mountain region have generally been referred." However, Weed (1893, p. 18) again assigned the coal-bearing formation at Livingston, Mont., to the Laramie Formation; partly on the basis of Knowlton's work and partly on the conformable relation with underlying rocks (Telegraph Creek Formation) believed to be of Montana age. The basal massive sandstone (Virgelle Sandstone Member of the Eagle Sandstone) was assigned by Weed $(1893$, p. 19) to the Fox Hills Sandstone. The Laramie Formation, according to Weed $(1893$, p. 34$)$, was overlain unconformably by his Livingston Formation. Stanton (in Stone and Calvert, 1910, p. 659-660) identified marine fossils of early Montana age from beds at the base of the coal-bearing formation east of the Bridger Range and correlated the formation with the Eagle Sandstone in the northern part of the Crazy Mountains basin as established there by Stone $(1909$, p. 78$)$.

The first comprehensive study of a megafauna from the Eagle Sandstone and related formations in the western interior of the United States was made by Reeside (1927). Strata north of Livingston that contain a marine fauna were assigned to the lower part of the Montana Group of the Upper Cretaceous (Reeside, 1927, p. 1).

At Cokedale the Eagle Sandstone contains a few sporadic poorly preserved Inoceramus sp. and Ostrea sp. To the north in the SE $1 / 4$ sec. 24, T. 4 N., R. 7 E., J. R. Gill and the author collected Inoceramus sp., Ostrea sp., Crassatella sp., and Tellina sp. from the Eagle Sandstone. G. D. Fraser (written commun., 1961) collected the following fossils, which were identified by W. A. Cobban, from the upper part of the Eagle near Gardiner, Mont., 0.9 mile east-southeast of the mouth of the Gardner River on the south bank of the Yellowstone River: Inoceramus sp., Crassostrea cf. C. soleniscus (Meek), Anomia sp., Ostrea coalvillensis Meek, and Cymbophora arenaria (Meek). According to
W. A. Cobban (written commun., 1961), this fauna indicates that the top of the Eagle Sandstone at Gardiner is no younger than the lower part of the Eagle of central Montana and that an even older age is possible (fig. 2).

Near the middle of the Eagle Sandstone at USGS Paleobotany locality D4121 (refer to measured section 14, unit 37), R. H. Tschudy (written commun., 1969) identified the following palynomorphs from a sample of the Cokedale No. 3 coal bed:

$\begin{array}{lc}\text { Gleicheniidites } & \text { Eucommiidites } \\ \text { Ephedra 10B } & \text { Polypodiacidites } \\ \text { Microfoveolatisporis } & \text { Stereisporites } \\ \text { Anemia } & \text { and the code species : } \\ \text { Inaperturopollenites } & \mathrm{C}_{3}-\mathrm{r} 10 \\ \text { Proteacidites } & \mathrm{CP}_{3}-\mathrm{fov} 2 \\ \text { Appendicisporites } & \mathrm{Pa}_{3}-\mathrm{Sm} 10 \mathrm{~B}\end{array}$

Most of these are long-ranging forms. Ephedra $10 \mathrm{~B}$ and $\mathrm{CP}_{3}$-fov 2 are the only forms present that are limited to the Eagle Sandstone.

\section{LIVINGSTON GROUP}

The name Livingston Formation was first applied by Weed $(1893$, p. 21) to the thick sequence of sedimentary rocks that consist chiefly of debris of andesitic lava and other volcanic rocks "typically developed in the vicinity of Livingston, Mont." (fig. 14). He divided the formation into three units-the leaf beds (lowest), the volcanic agglomerates, and the conglomerates. The volcanic agglomerate unit occurs only locally, 35 miles east of Livingston (Ross and others, 1955; fig. 14), and its stratigraphic position is uncertain. For a discussion of this unit the reader is referred to Vhay $(1934$, p. 57-71), Parsons (1942), and Garbarini (1957, p. 113-117). Vhay (1934, p. 66-71) concluded that the agglomerate unit is a series of mudflows that have modified pyroclastic ejecta. Peale (1896) extended the name Livingston westward to include predominantly pyroclastic deposits in Jefferson Canyon, southwest of Three Forks, Mont.; near Sphinx Mountain in the Madison Range; and in the Maudlow area at the north end of the Bridger Range (Peale, in Weed, 1893, p. 21). Iddings and Weed (1894) and Weed (1899b) assigned strata younger than the Eagle Sandstone in most of the Crazy Mountains basin to the Livingston Formation. Coal-bearing rocks in the northern part of the basin were first correlated with the Eagle Sandstone of Cretaceous age by Stone (1909, p. 78-79); however, he placed the Livingston in the Tertiary. Two years later, Stone and Calvert (1910, $p$. 551) demonstrated that the Livingston Formation grades laterally northeastward into marine and nonmarine beds of the Claggett, Judith River, Rearpaw, Lennep, and Lance (Hell Creek) Formations of Late 

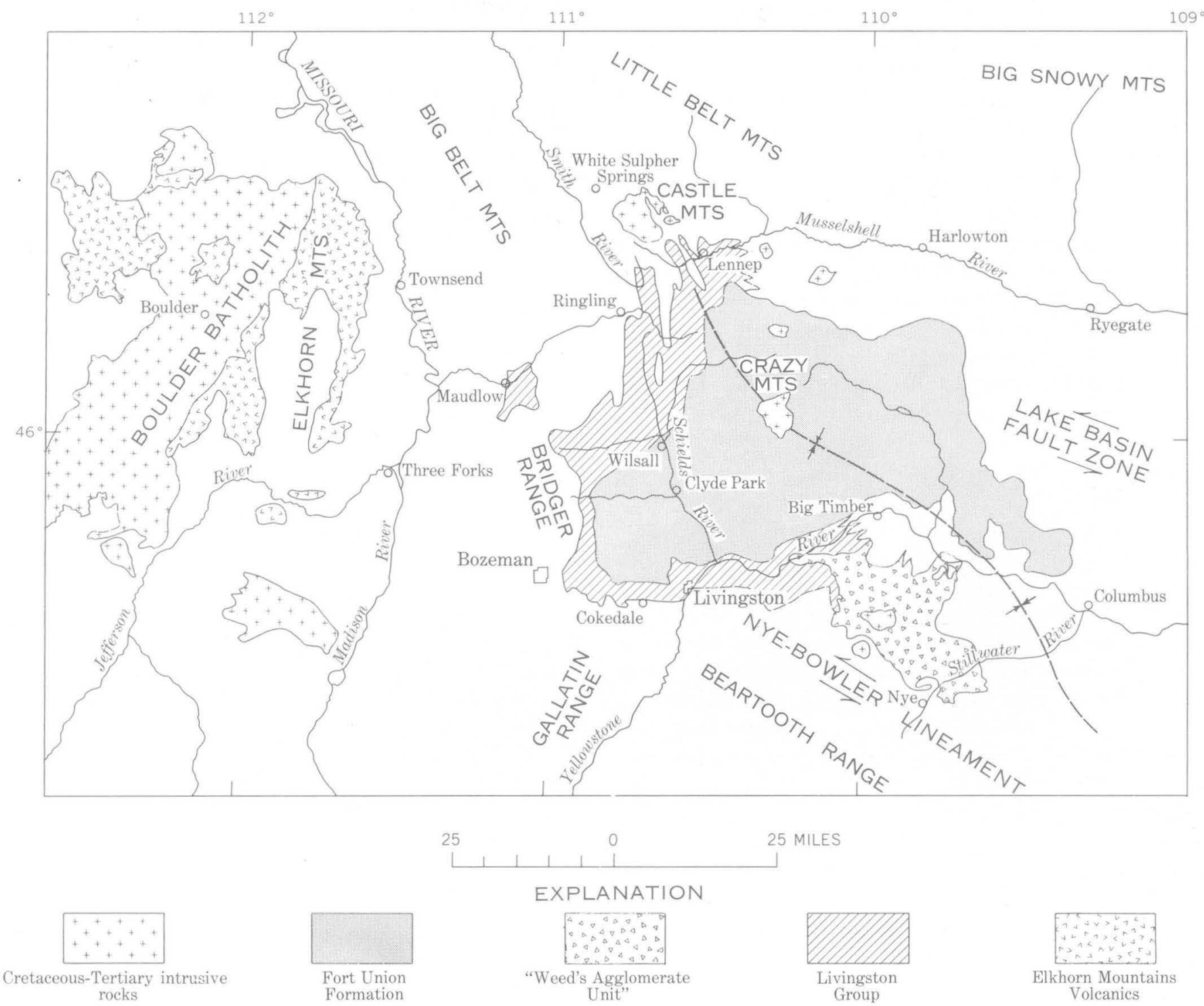

Dashed where approximately located

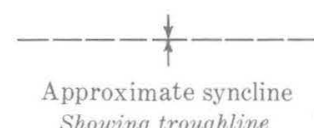

Figure 14,-Distribution of the Livingston Group in relation to the Crazy Mountains depositional basin and the Elkhorn Mountains source area in southwestern Montana.

Cretaceous age and the Lebo Andesitic Member of the Fort Union Formation of Paleocene age. Transgressive and regressive relations of these stratigraphic units were described by Stebinger (1914b, p. 67). No further stratigraphic studies of the Livingston were made in the southwestern part of the basin until McMannis (1955, p. 1407) and Richards (1957, p. 420) divided the formation into five generalized lithologic units, including the Fort Union Formation. Roberts (1963) named these units, raised the term Livingston to group rank, and excluded the Fort Union Formation.
Weed (1893, p. 18) assigned the coal-bearing formation (Eagle Sandstone) at Livingston, Mont., to the Laramie Formation, partly on the basis of Knowlton's work (1892, p. 153-154) and partly on the conformable relation with underlying rocks (Telegraph Creek Formation) believed to be of Montana age. The basal massive sandstone (Virgelle Sandstone Member of the Eagle Sandstone) was assigned by Weed (1893, p. 19) to the Fox Hills Sandstone. The Laramie Formation, according to Weed (1893, p. 34), was overlain unconformably by his Livingston Formation. Stanton (in 
Stone and Calvert, 1910, p. 659-660) identified marine fossils of early Montana age from beds at the base of the coal-bearing formation east of the Bridger Range and correlated the formation with the Eagle Sandstone established by Stone $(1909$, p. 78$)$ in the northern part of the Crazy Mountains basin.

Stone and Calvert (1910, p. 551) correlated Weed's Livingston Formation (1893, p. 21) as a "shore phase" of the Claggett Shale, Judith River Formation, Bearpaw Shale, Lennep Sandstone, Lance Formation, and Lebo Andesitic Member of the Fort Union Formation. Roberts (1963) subdivided this sequence of nonmarine sedimentary rocks into five formations, the lower four being restricted to the Livingston Group and the upper formation being assigned to the Fort Union Formation. The Livingston Group, as restricted by Roberts (1963), includes (in ascending order) the Cokedale, Miner Creek, Billman Creek, and Hoppers Formations. The correlation and stratigraphic relations of the type Livingston Group near Livingston, Mont., with rocks in other areas in Montana and Wyoming are shown in figure 2. Stratigraphic assignments of these nonmarine formations were aided by comparing pollen and spore assemblages. These microfossils were identified by E. B. Leopold and R. H. Tschudy and are listed in table 4.

The Cokedale Formation is a nonmarine unit composed largely of siltstone and sandstone and lesser amounts of mudstone, tuff, bentonite, and lignite which occur mostly in the lower part. The Cokediale rests conformably on the Eagle Sandstone and correlates in central Montana with the Claggett Shale, Judith River Formation, and Bearpaw Shale and in northwestern Montana with part of the Two Medicine Formation. The Miner Creek Formation conformably overlies the Cokedale and consists largely of alternating beds of nonmarine siltstone and sandstone including a prominent ridge-forming unit, the Sulphur Flats Sandstone Member, at the base. The Miner Creek correlates eastward with the lower part of the Hell Creek Formation, and the Sulphur Flats Sandstone Member is probably the nonmarine facies of the marine Lennep Sandstone and Horsethief Sandstone to the north. The overlying Billman Creek Formation is a nonmarine sequence of red, purple, and green mudstone intercalated with a few beds of tuff, bentonite, and sandstone. The Billman Creek rests conformably on the Miner Creek Formation and correlates north ward and eastward with the middle part of the Hell Creek Formation. The upper part contains the same pollen and spores as the type Colgate Member of the Fox Hills Sandstone at Glendive, Mont. The overlying Hoppers Formation, also nonmarine, is a sequence of sandstone and conglomerate interbedded with some siltstone, mudstone, and tuff. The Hoppers correlates northward and eastward with the upper part of the Hell Creek Formation.

The Livingston Group at Cokedale, Mont. (pl. 2), is a thick alternating series of coarse- and fine-grained continental deposits that have rapid vertical and lateral variations in lithology. The Livingston rocks probably represent fluvial channel systems and extensive floodplain deposits near sea level as indicated by their similarities to Holocene deposits that have these origins. The strata are characterized: by poor sorting; angularity of grains; crossbedding; thick sequences in which mudstone and sandstone alternate; mudstone-pebble conglomerates; oxidized zones; and the presence of freshwater gastropods and pelecypods, fragments of dinosaur bones, and wood and leaf debris. The continental sequence of the Livingston Group at Cokesdale could be the result of large variations in the quantity of sediment deposited in the rapidly subsiding western part of the Crazy Mountains basin. Changes from coarse- to fine-grained clastic rocks may represent fluctuations in supply of sediment along the basin margin that resulted from periodic uplift in slightly different locales, changes in elevation by volcanic eruptions, and the extrusion of volcanic rocks of different susceptibility to erosion in the source area. Renewed erosional activity resulting from any of these conditions, and (or) renewed downwarping of the basin, periodically caused the coarser grained sediment to spread farther basinward across finer grained offshore marine sediments. Conversely, a decrease in the amount of erosion from the source areas, and (or) uplift of the basin, periodically permitted the finer grained offshore marine sediments to transgress westward across the coarse-grained nearshore deposits.

Many sandstone units within the Livingston Group are conglomeratic. The cobbles and pebbles of these units consist mainly of various kinds of andesitic volcanic rock. Certain heavy minerals-such as sillimanite, corundum, staurolite, and garnet-in the sandstone units indicate a Precambrian source of lesser importance than the volcanic source; however, lithic fragments of Precambrian rock are not present, suggesting very little exposure or uplift of Precambrian rocks in the source area in comparison with the andesitic volcanic rocks. Some conglomeratic sandstones contain coarse sand to pebble-sized tabular fragments of mudstone in scour-and-fill structures. The edges of these fragments are generally rounded, which indicates a short distance of transport. These coarse-grained clastic deposits thin eastward. 
TABLE 4.-Checklist of plant and miscellaneous microfossils from the type Livingston Group and the Fort Union Formation near Livingston, Mont.

[Identiflcations by E. B. Leopold and R. H. Tschudy. Numbers preceded by D indicate US GS Paleobotany localities]

\begin{tabular}{|c|c|c|c|c|c|c|c|c|c|c|}
\hline \multirow{5}{*}{ Provislonal palynomorph genera } & \multirow{5}{*}{ Code species } & \multicolumn{8}{|c|}{ Upper Cretaceous } & Paleocene \\
\hline & & \multicolumn{7}{|c|}{ Livingston Group } & \multicolumn{2}{|c|}{$\begin{array}{l}\text { Fort Union Formation } \\
\text { (Measured section 20) }\end{array}$} \\
\hline & & \multicolumn{3}{|c|}{$\begin{array}{l}\text { Cokedale Formation } \\
\text { (Measured section 16) }\end{array}$} & \multicolumn{2}{|c|}{$\begin{array}{c}\text { Miner Creek } \\
\text { Formation } \\
\text { (Measured } \\
\text { section 17) }\end{array}$} & \multicolumn{2}{|c|}{$\begin{array}{l}\text { Billman Creek } \\
\text { Formation } \\
\text { (Measured } \\
\text { section 18) }\end{array}$} & \multirow[t]{2}{*}{$\begin{array}{c}\text { Basal } \\
\text { member } \\
\text { (upper) }\end{array}$} & \multirow[t]{2}{*}{$\begin{array}{c}\text { Middle } \\
\text { member } \\
\text { (lower) }\end{array}$} \\
\hline & & & & Middle & Lower & Upper & Middle & Upper & & \\
\hline & & D 1610 & D1611 & $\begin{array}{l}\text { D1815-1 } \\
\text { and } \\
\text { D4120 }\end{array}$ & D 1612 & D1613 & D1614 & $\mathrm{D} 4104 \mathrm{~A}$ & $\begin{array}{l}\text { D1782 } \\
\text { and } \\
\text { D4105 }\end{array}$ & D1783 \\
\hline
\end{tabular}

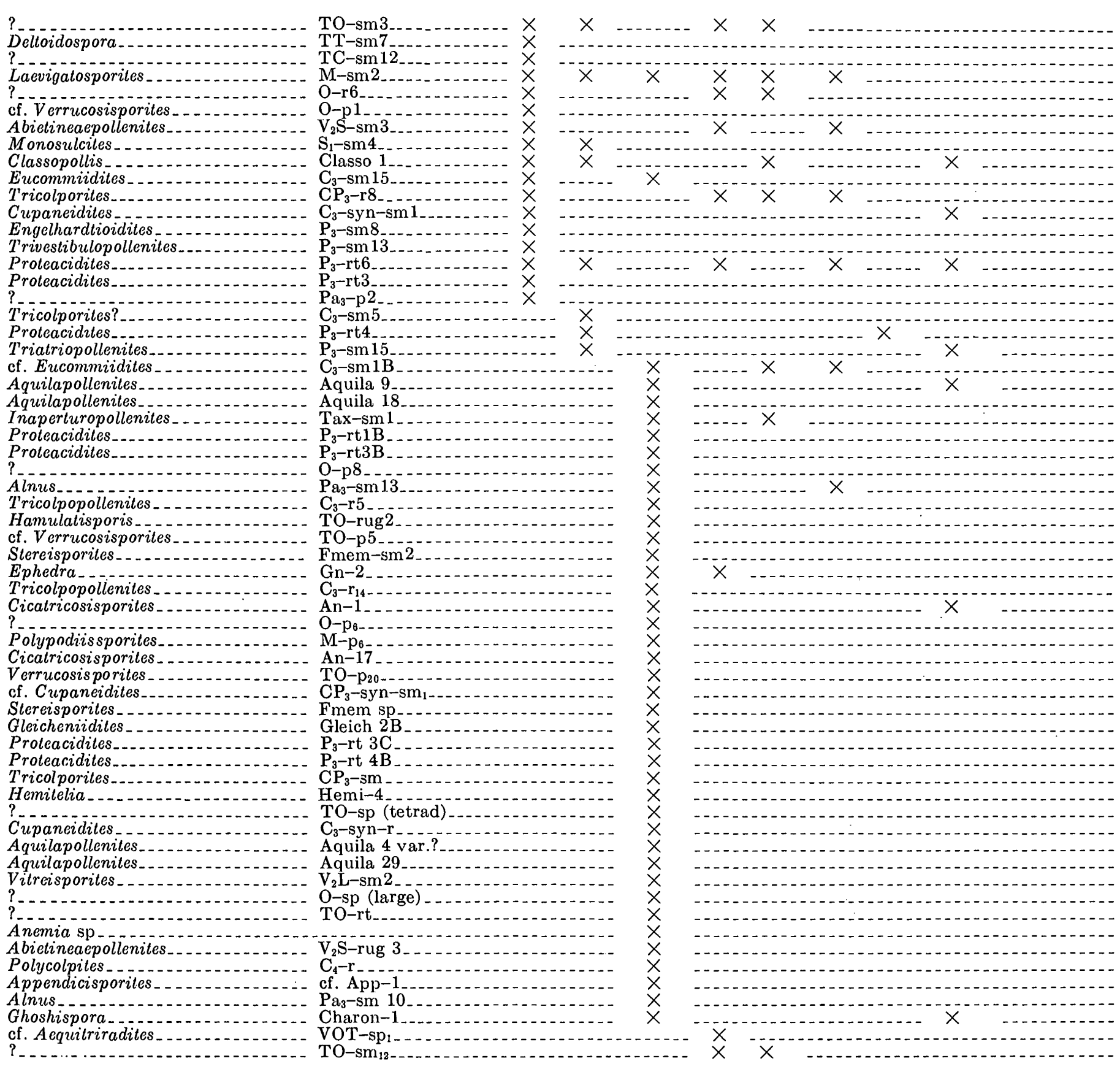


TABLE 4.-Checklist of plant and miscellaneous microfossils from the type Livingston Group and the Fort Union Formation near Livingston, Mont.-Continued

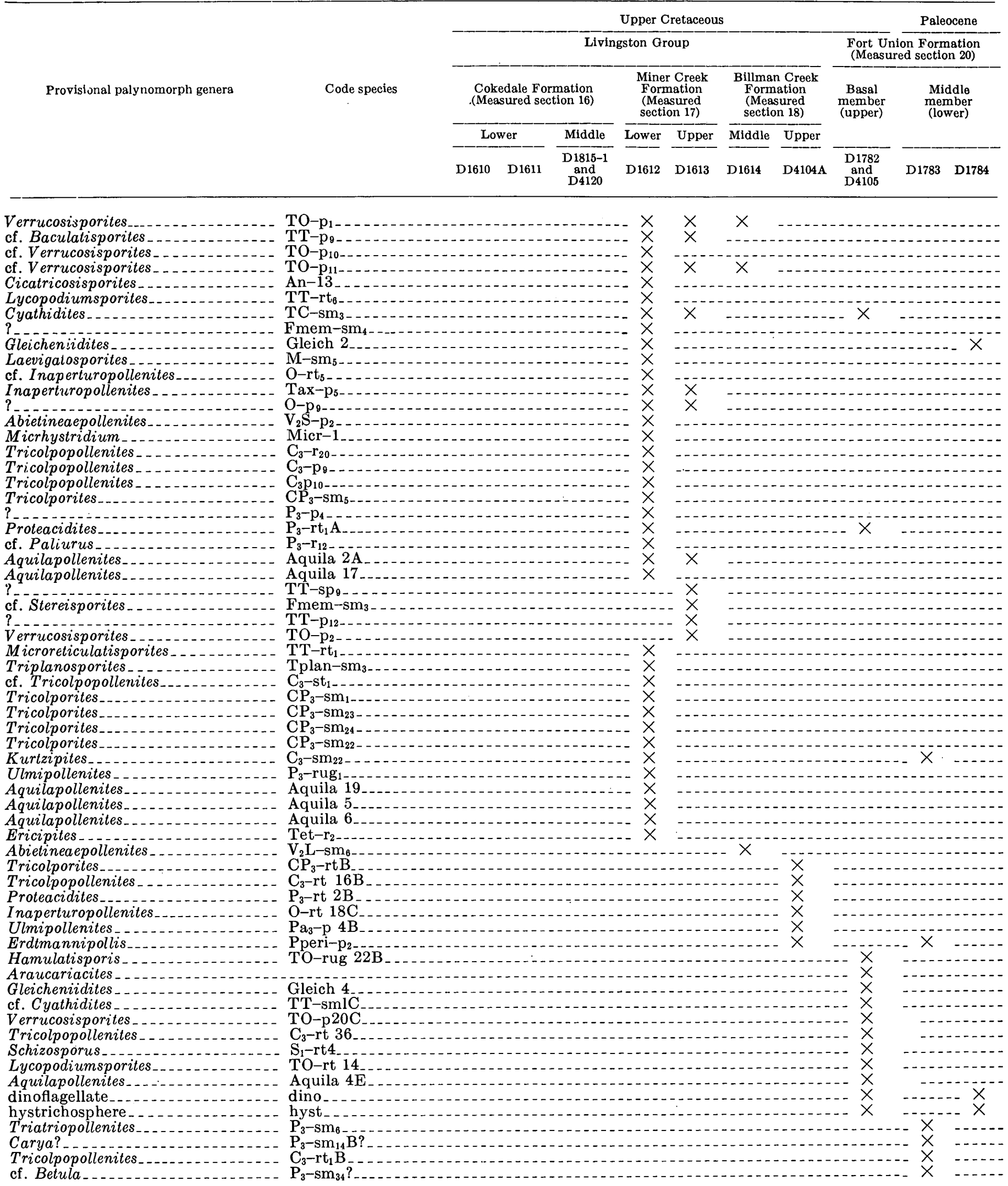


TAвLE 4.-Checklist of plant and miscellaneous microfossils from the type Livingston Group and the Fort Union Formation near Livingston, Mont.-Continued

\begin{tabular}{|c|c|c|c|c|c|c|c|c|c|}
\hline \multirow{5}{*}{ Provisional palynomorph genera } & \multirow{5}{*}{ Code species } & \multicolumn{7}{|c|}{ Upper Cretaceous } & Paleocene \\
\hline & & \multicolumn{6}{|c|}{ Livingston Group } & \multicolumn{2}{|c|}{$\begin{array}{l}\text { Fort Union Formation } \\
\text { (Measured section 20) }\end{array}$} \\
\hline & & \multicolumn{2}{|c|}{$\begin{array}{l}\text { Cokedale Formation } \\
\text { (Measured section 16) }\end{array}$} & \multicolumn{2}{|c|}{$\begin{array}{l}\text { Miner Creek } \\
\text { Formation } \\
\text { (Measured } \\
\text { section 17) }\end{array}$} & \multicolumn{2}{|c|}{$\begin{array}{l}\text { Billman Creek } \\
\text { Formation } \\
\text { (Measured } \\
\text { section 18) }\end{array}$} & \multirow[t]{2}{*}{$\begin{array}{c}\text { Basal } \\
\text { member } \\
\text { (upper) }\end{array}$} & \multirow[t]{2}{*}{$\begin{array}{l}\text { Middle } \\
\text { member } \\
\text { (lower) }\end{array}$} \\
\hline & & Lower & Middle & Lower & Upper & Middle & $\overline{\text { Upper }}$ & & \\
\hline & & D1610 & $\begin{array}{c}\text { D1815-1 } \\
\text { and } \\
\text { D4120 }\end{array}$ & D 1612 & D1613 & D1614 & D4104A & $\begin{array}{l}\text { D1782 } \\
\text { and } \\
\text { D4105 }\end{array}$ & D1783 \\
\hline
\end{tabular}

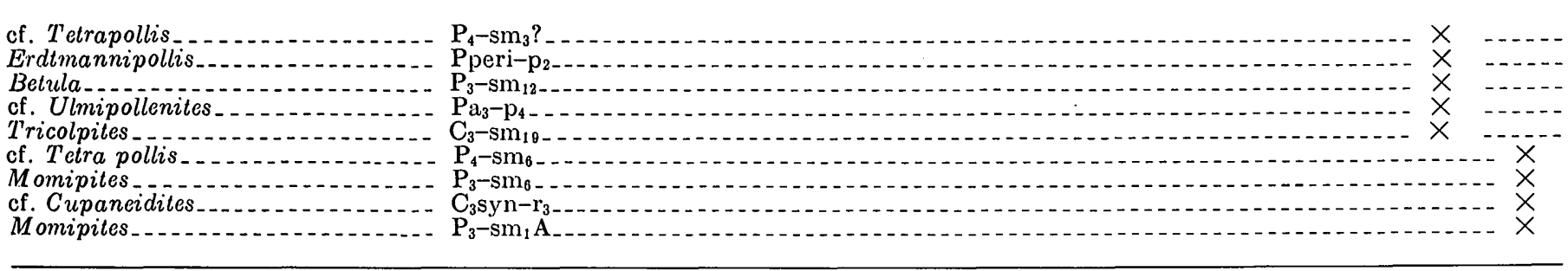

Crossbedded or cross-laminated strata that are mostly foreset beds are common throughout the coarser clastic units of the Livingston Group, particularly within the sandstone units. Individual foreset beds range in thickness from laminae to beds more than 4 feet thick.

The Livingston Group thins progressively eastward from Livingston toward Columbus, Mont. (Roberts, 1963 , p. B87). At Cokedale the sequence is 6,445 feet thick, but it is represented by only 2,750 feet of marine and nonmarine beds near Columbus, Mont. It also thins from Livingston northward to Lennep, Mont., where it includes 4,900 feet of marine and nonmarine beds. The overlying Fort Union Formation likewise thins markedly from Livingston to the east and north. In both directions, rocks of the Livingston and Fort Union become finer grained, better sorted, thinner bedded, lighter in color, and less andesitic in composition (McMannis, 1955) because of an increase in the proportions of quartz and orthoclase. The nonmarine Livingston Group interfingers with marine equivalents in both directions (fig. 2).

In the Livingston type section near Livingston, two prominent tuffaceous zones have regional significance in correlation. A lower tuffaceous zone in the lower part of the Cokedale Formation contains fossils of the Baculites obtusus faunal zone, which is found in the basal part of the Claggett Shale at the horizon of the Ardmore Bentonite Bed of the Sharon Springs Member of the Pierre Shale in other parts of Montana and in Wyoming. An upper tuffaceous zone in the lower part of the Miner Creek Formation represents the Baculites compressus and Baculites cuneatus faunal zones found in the upper part of the Judith River Formation and lower part of the Bearpaw Shale elsewhere in Mon- tana and in Wyoming. The regional stratigraphic significance of bentonitic shale zones at these horizons in the Pierre Shale or its formational equivalents in the northern Great Plains was discussed by Gill and Cobban (1966).

The composition of the volcanic fragments and minerals of volcanic origin in the Livingston Group and Fort Union Formation indicates that they were derived principally from the Elkhorn Mountains volcanic field near Boulder, Mont. (fig. 14). Smedes (1966, p. 21) described the petrology of the Elkhorn Mountains Volcanics as "a lower unit dominantly of andesitic, rhyodacitic, and basaltic pyroclastic and epiclastic volcanic rocks, autobrecciated lavas, and related mudflows. and a few thin partly welded quartz latitic ash flows; a middle unit characterized by sheets of rhyolitic ash flows, most of which now are welded tuff, and intercalated debris similar to that of the lower unit; and an upper unit dominated by bedded and water-laid tuff and andesitic sedimentary rocks."

Lindgren (1886, p. 719) first mapped and examined petrographically the eruptive rocks in and adjacent to the Crazy Mountains basin of which many were source rocks for the Livingston Group and Fort Union Formation. He described many rock types, andesites being the most common. Lindgren (1886, p. 736-737) concluded from his regional study of the eruptive rocks in the Big Belt Mountains that the andesitic eruptions probably began late in the Cretaceous Period or in Laramide time and lasted with different intensity until or after the end of that orogenic period. Later Billingsley (1915, p. 35) examined these rocks and stated that the andesite conglomerate at Maudlow (equivalent to a part of the lower Livingston) (Skipp and Peterson, 1965) 
could have no other source than the lavas of the Elkhorn Mountains. Berry (1943, p. 22-23), McMannis (1955, p. 1412), and Klepper, Weeks, and Ruppel (1957, p. 40) also concluded that the thick deposits of volcanic material in the Elkhorn Mountains were most likely the source of much of the Livingston.

Several small source areas of much less extent than the Elkhorn Mountains volcanic pile contributed to the sediments near the southern, western, and northwestern margins of the Crazy Mountains basin. A local source near Flathead Pass in the Bridger Range was suggested by Weed $(1893$, p. 29), and another source area near the Castle Mountains was suggested by Tanner (1949, p. 86). A local source south of Big Timber, Mont., was first described by Weed (1893, p. 26-29) for his "volcanic agglomerates" unit and later by Parsons (1942, p. 1177) for the "Livingston igneous series." In the vicinity of Nye, Mont., volcanic breccias considered to be part of the "Livingston igneous series" by
Parsons were derived from small local vents, probably as mudflows (Vhay, 1939, p. 436-437), and are interbedded with the Judith River Formation (Wilson, 1936, p. 1168). The volcanic activity which produced the various rocks assigned to the "Livingston igneous series" probably ceased prior to Hell Creek time (Parsons, 1942, p. 1183).

An eastward increase in abundance of quartz and other minerals of nonvolcanic origin, a decrease in grain size eastward across the Crazy Mountains basin, the presence of volcanic rock known only from the Elkhorn Mountains Volcanics in conglomerate beds of the Livingston Group, and the eastward wedging out of the extrusive units at Maudlow, Mont., corroborate the conclusion of Billingsley, Berry, McMannis, and Klepper that the major volcanic source was to the west and northwest of the basin (fig. 14).

Volcanic material in the Livingston Group includes fragments of several types and textures of andesitic and

Г ABLE 5.-Chemical (rapid rock) analyses of very fine grained clastic rocks from the Livingston Group and of comparative samples from the Telegraph Creek Formation and Eagle Sandstone at Cokedale, Mont.

[Data in percent. Sampled by L. G. Schultz; analyses by L. Artis, S. Botts, A. Chloe, P. Elmore, and H. Smith]

\begin{tabular}{|c|c|c|c|c|c|c|c|c|c|c|}
\hline \multirow{3}{*}{$\begin{array}{l}\text { Formation } \\
\text { Data system No } \\
\text { Lab. No }\end{array}$} & \multicolumn{3}{|c|}{ Billman Creek } & \multicolumn{2}{|c|}{ Miner Creek } & \multicolumn{2}{|c|}{ Cokedale } & \multirow{2}{*}{$\frac{\text { Eagle }}{\mathrm{D}_{159829} 000045}$} & \multicolumn{2}{|c|}{ Telegraph Creek } \\
\hline & $\mathrm{D}_{159822}^{0000638}$ & $\mathrm{D}_{159823}^{0000639}$ & $\mathrm{D}_{159824}^{0000640}$ & $\mathrm{D}_{159825}^{0000641}$ & $\begin{array}{c}D_{159826}^{0000642} \\
.\end{array}$ & $\mathrm{D}_{159827}^{0000643}$ & $\begin{array}{c}\mathrm{D}_{159828} 0000644 \\
\end{array}$ & & $\mathrm{D}_{159830} 0000646$ & D $\underset{159831}{0000647}$ \\
\hline & 1 & 2 & 3 & 4 & 5 & 6 & 7 & 8 & 9 & 10 \\
\hline 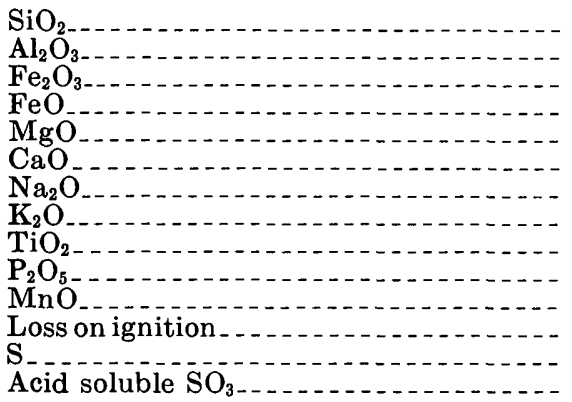 & $\begin{array}{l}\text { 57. } 7 \\
\text { 15. } 1 \\
\text { 5. } 8 \\
.54 \\
2.7 \\
\text { 1. } 8 \\
\text { 1. } 0 \\
\text { 2. } 5 \\
.64 \\
.26 \\
\text { 11. } 21 \\
\text { (*) } \\
\text { (*) }\end{array}$ & $\begin{array}{l}\text { 57. } 7 \\
\text { 15. } 5 \\
\text { 6. } 0 \\
\text { 2. } 47 \\
\text { 2. } 8 \\
2.0 \\
\text { 3. } 0 \\
.59 \\
.11 \\
.09 \\
\text { 7. } 9 \\
(*) \\
(*)\end{array}$ & $\begin{array}{l}\text { 60. } 0 \\
\text { 14. } 3 \\
\text { 5. } 2 \\
\text {. } 60 \\
\text { 3. } 1 \\
\text { 2. } 2 \\
\text { 1. } 8 \\
\text { 2. } 7 \\
.57 \\
.29 \\
.09 \\
\text { 8. } 8 \\
(*) \\
(*)\end{array}$ & $\begin{array}{c}60.1 \\
16.0 \\
5.3 \\
.36 \\
1.3 \\
2.1 \\
1.2 \\
2.2 \\
.55 \\
.21 \\
.05 \\
10.4 \\
(*) \\
(*)\end{array}$ & $\begin{array}{c}59.3 \\
16.6 \\
5.3 \\
.62 \\
1.2 \\
2.5 \\
1.6 \\
2.3 \\
.53 \\
.08 \\
.05 \\
9.9 \\
(*) \\
(*)\end{array}$ & $\begin{array}{c}61.1 \\
18.0 \\
4.5 \\
.47 \\
.79 \\
3.7 \\
3.3 \\
1.6 \\
.56 \\
.13 \\
.10 \\
6.0 \\
(*) \\
(*)\end{array}$ & $\begin{array}{c}70.7 \\
13.8 \\
2.1 \\
.85 \\
\text { 1. } 4 \\
.58 \\
.50 \\
4.1 \\
.53 \\
.07 \\
.02 \\
5.3 \\
(*) \\
(*)\end{array}$ & $\begin{array}{c}57.7 \\
11.3 \\
1.8 \\
1.5 \\
3.5 \\
7.5 \\
.49 \\
2.7 \\
.45 \\
.24 \\
.04 \\
12.2 \\
(*) \\
(*)\end{array}$ & $\begin{array}{c}\text { 56. } 1 \\
11.2 \\
2.2 \\
.98 \\
3.7 \\
8.4 \\
.79 \\
2.4 \\
.45 \\
.22 \\
.03 \\
13.7 \\
(*) \\
(*)\end{array}$ & $\begin{aligned} 60.1 \\
16.1 \\
5.3 \\
.80 \\
1.9 \\
.46 \\
1.2 \\
2.4 \\
.66 \\
.11 \\
.02 \\
10.2 \\
.00 \\
.75\end{aligned}$ \\
\hline Sum $_{-}$ & 99 & 99 & 100 & 100 & 100 & 100 & 100 & 99 & 100 & 100 \\
\hline $\begin{array}{l}\mathrm{H}_{2} \mathrm{O} \\
\mathrm{H}_{2} \mathrm{O}+ \\
\mathrm{CO}_{2} \\
\text { Powder density by air pycnometer }\end{array}$ & $\begin{array}{l}\text { 6. } 8 \\
\text { 4. } 7 \\
<.05 \\
2.47\end{array}$ & $\begin{array}{l}\text { 3. } 7 \\
\text { 4. } 0 \\
.20 \\
2.57\end{array}$ & $\begin{array}{l}5.0 \\
\text { 4. } 0 \\
<.05 \\
2.52\end{array}$ & $\begin{array}{l}6.4 \\
\text { 4. } 1 \\
<.05 \\
2.49\end{array}$ & $\begin{array}{l}5.7 \\
4.4 \\
<.05 \\
2.48\end{array}$ & $\begin{array}{l}2.6 \\
3.6 \\
<.05 \\
2.59\end{array}$ & $\begin{array}{l}1.6 \\
3.6 \\
.20 \\
2.65\end{array}$ & $\begin{array}{l}\text { 1. } 3 \\
\text { 3. } 5 \\
\text { 7. } 6 \\
\text { 2. } 70\end{array}$ & $\begin{array}{l}\text { 1. } 7 \\
\text { 3. } 6 \\
\text { 8. } 5 \\
2.70\end{array}$ & $\begin{array}{l}4.3 \\
\text { 5. } 4 \\
.12 \\
\text { 2. } 63\end{array}$ \\
\hline
\end{tabular}

*Less than 0.2 percent $\mathrm{S}$ as $\mathrm{SO}_{3}$.

1. Volcanic silty claystone; SE $1 / 4 \mathrm{SW} 1 / 4 \mathrm{NW} 1 / 4$ sec. $18, \mathrm{~T}$. $2 \mathrm{~S}$., R. $9 \mathrm{E}$.; 1,800 ft above base of formation.

2. Volcanic siltstone, NE $1 / 4 \mathrm{SW}_{1} / 4 \mathrm{SW}^{1} 4$ sec. 18, T. $2 \mathrm{~S}$., R. $9 \mathrm{E}$.; $915 \mathrm{ft}$ above base of formation.

3. Volcanic claystone; SE1/4 NE1/4 SW14 sec. 13, T. $2 \mathrm{~S}$., R. $8 \mathrm{E}$.; $560 \mathrm{ft}$ above base of formation.

4. Volcanic siltstone; NW1/4SW1/4NW1/4 sec. $20, \mathrm{~T}$. 2 S., R. $9 \mathrm{E}$.; $1,100 \mathrm{ft}$ above base of formation.

5. Volcanic clayey siltstone; NE 14 NE1/4SE1/4 sec. 19, T. 2 S., R. 9 E.; 505 ft above base of formation.

6. Volcanic sandy claystone; $\mathrm{SE} / 4 \mathrm{NW} / 4 \mathrm{SW} 1 / 4$ sec. $23, \mathrm{~T}$. $2 \mathrm{~S}$., R. $8 \mathrm{E}$.; 1,125 ft above base of formation.

7. Clayey siltstone; SE1/4SW1/4 sec. 24 , T. 2 S., R. 8 E.; $315 \mathrm{ft}$ above base of formation.

8. Clayey siltstone; NW1/4 NE1/4NW1/4 sec. 26, T. 2 S., R. 8 E.; $200 \mathrm{ft}$ above base of formation.

9. Clayey siltstone; SE1/4 NW1/4N W1/4 sec. 26, T. 2 S., R. 8 E.; $200 \mathrm{ft}$ above base of formation.

10. Silty claystone; SE $1 / 4$ NW1/4 NW1/4 sec. $26, \mathrm{~T} .2 \mathrm{~S} ., \mathrm{R} .8 \mathrm{E}$.; $150 \mathrm{ft}$ above base of formation. 
possibly some latitic rocks, as well as beds of bentonite and andesitic ash. Samples from very fine grained clastic rocks were chemically analyzed, and the analyses are summarized in table 5. Also present in smaller amounts are lithic fragments of welded tuff, spherulitic and devitrified rocks that may be dacitic in composition, crystal fragments of volcanic and nonvolcanic origin, and clay minerals. The Livingston Group contains a distinct heavy-mineral suite which is summarized together with grain-size distribution in table 6 .

The dominant mineral in the heavy-mineral fraction from the Livingston Group, as well as in the overlying Fort Union Formation, is clinopyroxene (table 6). The optical properties of the clinopyroxene mineral place it in the salite-diopsidic augite field, the typical clinopyroxene of intermediate to basic volcanic rocks (R. E. Wilcox, written commun., 1968).

A copper mineral present in most samples from the Livingston Group (table 6) is whitneyite (Fred A. Hilderbrand, oral commun., 1966). This mineral is a copper arsenide and was identified by $\mathrm{X}$-ray analyses. It has some physical characteristics similar to those of gold, such as color and malleableness, that can be misleading; thus detailed examination, such as X-ray or chemical analysis, is required for identification. These characteristics become apparent only after the rock sample has been chemically disaggregated; this process removes the thin oxidized coating on the whitneyite grains. The presence of copper arsenide suggests a probable Precambrian source south of Livingston, such as the Jardine mining district near Gardiner, Mont., because that area is rich in arsenic and related minerals, including native copper (Seager, 1944). Also, the area near Gardiner seems a likely source because beds in the lower part of the Cokedale Formation of the Livingston Group that contain the oldest occurrences of whitneyite are believed to be slightly older than the mineralization of a possible alternate source, the Boulder batholith area of western Montana (fig. 1).

Plagioclase feldspar is the most abundant mineral of probable volcanic origin in the Livingston Group and the Fort Union Formation, after which, in order of decreasing abundance, are diopsidic augite, magnetite, biotite, and hornblende (table 6). The plagioclase ranges from oligoclase to labradorite; andesine is the most common. Potassium feldspar (orthoclase) and quartz are the principal nonvolcanic constituents. The feldspars are generally altered, in part to laumontite and other zeolite minerals, and in part to zoisite, sericite, and clay minerals. With the exception of two atypical quartzose sandstones in the Cokedale Formation and one at the base of the Sulphur Flats Sandstone Member of the Miner Creek Formation, quartz content increases progressively from trace amounts in the lower part of the Livingston to as much as 12 percent in the upper part. Orthoclase content also increases from trace amounts in the lower part to 15 percent in the upper part; this increase suggests a very gradual increase in the size of the source area in which pre-Elkhorn Mountains Volcanics rocks were exposed. Heavy minerals in the Livingston Group, such as sillimanite, corundum, staurolite, and garnet, were derived only from Precambrian metamorphic rocks; however, lithic fragments of these rocks are rare to absent, suggesting that the Precambrian exposures were much farther west or south or were not elevated as high and therefore were less exposed to erosion during deposition of the Livingston Group than later during deposition of the basal conglomeratic member of the Fort Union Formation in which such fragments are present.

Biotite grains in the quartzose sandstones are dark brown and similar to those in the pre-Livingston Group sedimentary rocks; however, biotite in the sandstones that contain volcanic detritus ranges from very light brown to dark brown. Commonly the light-colored variety is difficult to distinguish from muscovite, and the two mica minerals are combined in table 6. Bronzecolored biotite is a characteristic variety in the sandstones of the Miner Creek Formation. The different shades of brown of biotite in the Livingston Group probably represent differences in deuteric or hydrothermal alteration of rocks in the source area.

The finer grained rocks (claystones and mudstones) contain approximately 45 percent montmorillonite and 55 percent mixed-layer montmorillonite-illite-vermiculite; some also have small amounts of illite and chlorite (L. G. Schultz, oral commun., 1962). Kaolinite is generally absent.

Zeolite minerals are common in interstices in the sandstone. Reddish-brown heulandite is the most conspicuous zeolite and is present throughout the Livingston, but it is most abundant in the Miner Creek Formation. Analcime is present in some units as cement, producing a mottled texture because it has crystallized in clusters. Traces of laumontite and clinoptilolite are also present in some units. Other cementing agents are silica, calcite, nontronite, and chloritic minerals.

Stratigraphic sections described in this report extend from the abandoned coal-mining town of Cokedale, Mont., 9 miles west of Livingston, Mont., north to the axis of the Fleshman Creek syncline. Locations of these sections of the type formations in the Livingston Group are shown in figure 15. The total thickness of the Livingston Group is 6,455 feet. 
TABLE 6.-Heavy-mineral content and grain-size distribution in sandstones

[All data, in percent; indicated diameter,

\begin{tabular}{|c|c|c|c|c|c|c|c|c|c|c|c|c|c|c|c|}
\hline \multirow[b]{2}{*}{$\begin{array}{l}\text { Stratigraphic name, } \\
\text { measured section, and } \\
\text { unit sampled }\end{array}$} & \multirow{2}{*}{$\begin{array}{l}\text { Heavy } \\
\text { minerals in } \\
\text { the very } \\
\text { fne sand } \\
\text { fraction } \\
(0.088 \text { and } \\
0.062 \mathrm{~mm})\end{array}$} & \multicolumn{14}{|c|}{ Heavy minerals 1} \\
\hline & & Zircon & $\begin{array}{l}\text { Biotite } \\
\text { and } \\
\text { musco- } \\
\text { vite }{ }^{2}\end{array}$ & Sphene & $\underset{\text { nite }}{\text { Sillima- }}$ & $\begin{array}{l}\text { Hyper- } \\
\text { sthene }\end{array}$ & $\begin{array}{l}\text { Corun- } \\
\text { dum }\end{array}$ & $\begin{array}{l}\text { Stau- } \\
\text { rollte }\end{array}$ & $\begin{array}{l}\text { Tour- } \\
\text { maline }\end{array}$ & Epldote & Anatase & Topaz & Garnet & $\begin{array}{l}\text { Horn.. } \\
\text { blende }\end{array}$ & $\begin{array}{l}\text { Diop- } \\
\text { sidic } \\
\text { augite }\end{array}$ \\
\hline $\begin{array}{r}\text { Fort Union Formation: } \\
\text { Section } 20 . . . . . \text { unit } 242 \\
234 . \\
147 \\
81 . \\
35 \\
1 . \\
\text { Livingston Group, Hoppers }\end{array}$ & $\begin{array}{r}20.71 \\
23.76 \\
5.32 \\
3.72 \\
5.88 \\
13.01\end{array}$ & $\begin{array}{l}7.7 \\
5.4 \\
5.7 \\
9.0 \\
4.9 \\
7.9\end{array}$ & $\begin{array}{l}1.2 \\
1.4 \\
1.1 \\
1.0 \\
1.5 \\
1.0\end{array}$ & $\begin{array}{l}0.9 \\
.6 \\
2.0 \\
.8 \\
1.0 \\
.9\end{array}$ & $\begin{array}{l}0 \\
0 \\
0 \\
0 \\
0 \\
0\end{array}$ & $\begin{array}{l}1.9 \\
3.2 \\
2.4 \\
3.2 \\
4.4 \\
1.5\end{array}$ & $\begin{array}{l}0.5 \\
0 \\
.2 \\
0 \\
0.6\end{array}$ & $\begin{array}{l}0.4 \\
.2 \\
0 \\
0 \\
.2\end{array}$ & $\begin{array}{l}0 \\
0 \\
0 \\
0 \\
0 \\
0\end{array}$ & $\begin{array}{l}2.1 \\
.8 \\
1.8 \\
2.2 \\
1.8 \\
1.5\end{array}$ & $\begin{array}{l}0 \\
0 \\
.4 \\
0 \\
0 \\
0\end{array}$ & $\begin{array}{l}0.2 \\
0 \\
0 \\
0 \\
0\end{array}$ & $\begin{array}{l}2.4 \\
1.4 \\
5.3 \\
2.4 \\
2.9 \\
.6\end{array}$ & $\begin{array}{l}0.5 \\
.8 \\
.3 \\
0 \\
1.1\end{array}$ & $\begin{array}{l}65.1 \\
66.2 \\
72.0 \\
72.8 \\
62.3 \\
82.4\end{array}$ \\
\hline $\begin{array}{r}\text { Formation: } \\
\text { Section } 19 . . . . . . \text { unit } 48 \\
38 \\
28 \\
10 . \\
\text { Blllman Creek Formation: }\end{array}$ & $\begin{aligned} 15.19 \\
11.16 \\
29.79 \\
\text { b. } 62\end{aligned}$ & $\begin{array}{l}8.1 \\
6.5 \\
7.5 \\
7.8\end{array}$ & $\begin{array}{l}0 \\
.6 \\
1.5 \\
2.0\end{array}$ & $\begin{array}{r}1.0 \\
.6 \\
1.8 \\
1.4\end{array}$ & $\begin{array}{l}0 \\
0 \\
0 \\
0\end{array}$ & $\begin{array}{l}1.2 \\
1.3 \\
1.0 \\
1.8\end{array}$ & $\begin{array}{l}1.0 \\
1.7 \\
1.0 \\
1.2\end{array}$ & $\begin{array}{l}0 \\
0 \\
0 \\
.2\end{array}$ & $\begin{array}{l}0 \\
0 \\
0 \\
0\end{array}$ & $\begin{array}{r}1.0 \\
.9 \\
.2 \\
1.0\end{array}$ & $\begin{array}{l}0 \\
0 \\
0 \\
0\end{array}$ & $\begin{array}{l}0 \\
0 \\
0 \\
0\end{array}$ & $\begin{array}{l}0 \\
.6 \\
.4\end{array}$ & $\begin{array}{r}.2 \\
.4 \\
.5 \\
0\end{array}$ & $\begin{array}{l}77.9 \\
79.5 \\
83.0 \\
64.1\end{array}$ \\
\hline $\begin{array}{r}\text { Section } 18 \ldots . . . \text { unit } 158 . \\
135 . \\
91 . \\
52 . \\
28 . \\
2 . .\end{array}$ & $\begin{array}{r}5.88 \\
23.94 \\
12.43 \\
14.48 \\
11.07 \\
26.24\end{array}$ & $\begin{array}{l}4.3 \\
4.4 \\
5.4 \\
2.8 \\
2.6 \\
3.7\end{array}$ & $\begin{array}{l}.5 \\
.5 \\
.6 \\
.9 \\
.7 \\
.3\end{array}$ & $\begin{array}{l}2.4 \\
1.5 \\
0 \\
0 \\
0 \\
.2\end{array}$ & $\begin{array}{l}0 \\
0 \\
0 \\
0 \\
0 \\
0\end{array}$ & $\begin{array}{l}2.4 \\
3.1 \\
1.3 \\
2.1 \\
2.6 \\
.7\end{array}$ & $\begin{array}{l}0^{5} \\
0 \\
0 \\
0 \\
0\end{array}$ & $\begin{array}{l}0 \\
0 \\
0 \\
0^{2} \\
0\end{array}$ & $\begin{array}{l}0 \\
0 \\
0 \\
0 \\
0 \\
0\end{array}$ & $\begin{array}{l}0 \\
0 \\
0 \\
.9 \\
0 \\
.7\end{array}$ & $\begin{array}{l}0 \\
0 \\
0 \\
0 \\
0 \\
0\end{array}$ & $\begin{array}{l}0 \\
0 \\
0 \\
0 \\
0 \\
0\end{array}$ & $\begin{array}{l}1.0 \\
.2 \\
1.1 \\
0 \\
0 \\
0\end{array}$ & $\begin{array}{r}.2 \\
.7 \\
0 \\
.5 \\
.4 \\
.7\end{array}$ & $\begin{array}{l}70.0 \\
83.7 \\
84.4 \\
81.3 \\
90.8 \\
83.4\end{array}$ \\
\hline $\begin{array}{r}\text { Mection 17....... unit 155.- } \\
121 .- \\
83 .- \\
78 .- \\
54 .- \\
47 .- \\
45 .- \\
\text { Miner Creek Formation, Sul- } \\
\text { phur Flats Sandstone } \\
\text { Member: }\end{array}$ & $\begin{array}{r}23.72 \\
0.88 \\
5.16 \\
0.20 \\
0.07 \\
0.07 \\
2.60\end{array}$ & $\begin{array}{r}4.0 \\
5.7 \\
1.7 \\
12.9 \\
6.5 \\
17.4 \\
7.0\end{array}$ & $\begin{array}{l}0 \\
1.1 \\
1.0 \\
.8 \\
.2 .2 \\
5.1 \\
.7\end{array}$ & $\begin{array}{l}0 \\
.7 \\
0 \\
0 \\
.2 \\
0 \\
0\end{array}$ & $\begin{array}{l}0 \\
0 \\
.2 \\
.3 \\
.9 \\
.2 \\
.2\end{array}$ & $\begin{array}{l}1.7 \\
.7 \\
1.9 \\
1.4 \\
1.2 \\
.7\end{array}$ & $\begin{array}{l}.5 \\
0.7 \\
0 \\
1.1 \\
.6 \\
2.2 \\
.7\end{array}$ & $\begin{array}{l}0 \\
0.2 \\
0 . \\
0 \\
0 \\
0\end{array}$ & $\begin{array}{l}0 \\
0 \\
0 \\
.3 \\
0 . \\
.5 \\
.5\end{array}$ & $\begin{array}{l}0 \\
5.3 \\
3.8 \\
1.6 \\
1.7 \\
0 \\
1.0\end{array}$ & $\begin{array}{l}0 \\
0 \\
0 \\
0 \\
0 \\
{ }_{0}{ }^{2}\end{array}$ & $\begin{array}{l}0 \\
.9 \\
0 \\
1.1 \\
0 \\
0 \\
0\end{array}$ & $\begin{array}{l}0 \\
0 \\
.2 \\
1.4 \\
0 \\
.2 \\
.\end{array}$ & $\begin{array}{r}.9 \\
8.8 \\
9.1 \\
2.2 \\
0 \\
.2 \\
.5\end{array}$ & $\begin{array}{r}92.4 \\
13.4 \\
78.7 \\
7.7 \\
12.4 \\
2.9 \\
70.0\end{array}$ \\
\hline $\begin{array}{r}\text { Section } 17 \ldots \ldots . . . \text { unit } 43 \ldots \\
25 . \\
\text { Cokedale Formation: }\end{array}$ & $\begin{array}{l}0.49 \\
9.58 \\
0.23\end{array}$ & $\begin{array}{r}1.3 \\
4.8 \\
21.7\end{array}$ & $\begin{array}{l}.5 \\
0.5 \\
5.2\end{array}$ & $\begin{array}{l}0 . \\
0 \\
1.0\end{array}$ & $\begin{array}{c}31.8 \\
0 \\
0.2\end{array}$ & $\begin{array}{r}.8 \\
.5 \\
2.1\end{array}$ & $\begin{array}{l}2.2 \\
1.2\end{array}$ & $\begin{array}{l}0 \\
0 \\
2.6\end{array}$ & $\begin{array}{l}1.3 \\
.5 \\
2.6\end{array}$ & $\begin{array}{r}1.9 \\
6.8 \\
6.2\end{array}$ & $\begin{array}{l}0 \\
0 \\
0\end{array}$ & $\begin{array}{l}0 \\
0 \\
.2\end{array}$ & $\begin{array}{c}0 \\
0 \\
24.0\end{array}$ & $\begin{array}{l}3.8 \\
0 \\
0\end{array}$ & $\begin{array}{l}38.9 \\
89.1 \\
21.0\end{array}$ \\
\hline $\begin{array}{r}\text { Section } 16 . . . . . \text { unit } 159 . . \\
123 . \\
93 . . \\
82 .\end{array}$ & $\begin{array}{l}9.17 \\
0.26 \\
0.09 \\
0.12\end{array}$ & $\begin{array}{r}2.6 \\
13.8 \\
10.3 \\
30.2\end{array}$ & $\begin{array}{r}1.1 \\
3.0 \\
5.1 \\
14.3\end{array}$ & $\begin{array}{l}0 \\
1.1 \\
.5 \\
2.5\end{array}$ & $\begin{array}{l}0 \\
.7 \\
1.0 \\
1.5\end{array}$ & $\begin{array}{r}0 \\
1.9 \\
1.5 \\
12.4\end{array}$ & $\begin{array}{l}0 \\
0 \\
1.5 \\
.5\end{array}$ & $\begin{array}{l}0 \\
.4 \\
4.1 \\
1.5\end{array}$ & $\begin{array}{r}0 \\
.4 \\
.5 \\
6.4\end{array}$ & $\begin{array}{l}2.1 \\
2.6 \\
4.1 \\
9.4\end{array}$ & $\begin{array}{l}0 \\
2.2 \\
4.6 \\
1.5\end{array}$ & $\begin{array}{l}0 \\
0 \\
0 \\
1.0\end{array}$ & $\begin{array}{l}0 \\
.7 \\
1.0 \\
1.0\end{array}$ & $\begin{array}{l}0 \\
0 \\
.5 \\
0\end{array}$ & $\begin{array}{r}93.1 \\
10.8 \\
4.1 \\
5.0\end{array}$ \\
\hline
\end{tabular}

1 Percent of heavy-mineral fraction of the size fraction $(0.088$ and 0.062$)$ used for heavy-mineral analysis, percent to nearest 0.1

2 Biotite commonly is a very light colored variety and is included with muscovite.

\section{COKEDALE FORMATION}

The Cokedale Formation was named by Roberts (1963) for exposures in the $\mathrm{S} 1 / 2$ sec. 23 and the NE1/4 sec. 26 , T. 2 S., R. 8 E. (fig. 15), immediately north of the former coal-mining town of Cokedale, Mont. At the type section, the formation conformably and gradationally overlies the Eagle Sandstone and is 1,550 feet thick (fig. 16).

Weed (1893, p. 11) described the difference in lithology that is the basis for separating the Livingston Formation from the underlying Eagle Sandstone and stated that the two formations were separated by an unconformity. As a result of their regional studies in the Crazy Mountains basin, Stone and Calvert (1910, p. 761) recognized the Livingston Formation at the type locality as conformably overlying the Eagle. Roberts (1957, p. $47 ; 1963$, p. B90) arbitrarily designated the top of an arkosic sandstone that overlies the uppermost minable coal bed of the Eagle Sandstone as the contact with the Livingston, and this horizon is taken as the base of the Cokedale. Some andesitic sandstone occurs in the upper part of the Eagle Sandstone, and some arkosic sandstone and coal occurs in the lower part of the Cokedale Formation; nevertheless, the indicated boundary is the most easily recognized contact in the Livingston area. A difference in physical and chemical properties of the coals in the upper part of the Eagle (bituminous-coking) compared with those in the lower part of the Cokedale (lignite-noncoking) is also a good reason to choose this boundary. A thin, black chert-pebble conglomerate that marks the top of the Eagle or base of the Claggett throughout much of south-central Montana (Hancock, 1918, p. 115; Knappen and Moulton, 1931, p. 37) was not found in the section at Cokedale.

\section{Lithologic Composition}

The Cokedale Formation consists of siltstone, sandstone, mudstone, water-laid tuff, bentonite, and carbonaceous claystone; and coal is present in the lower part (measured section 16). The sedimentary rocks were derived mostly from volcanic rocks of andesitic composition.

Siltstone forms about 50 percent of the Cokedale Formation. The siltstone is generally massive bedded, tuffaceous, and commonly olive gray, weathering to 
in the type Livingston Group and Fort Union Formation, Cokedale, Mont.

In millimeters. Analyses by R. F. Gantnier]

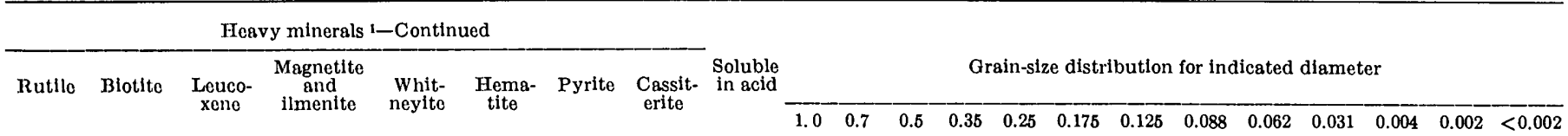

\begin{tabular}{|c|c|c|c|c|c|c|c|c|c|c|c|c|c|c|c|c|c|c|c|c|c|}
\hline $\begin{array}{l}0.4 \\
0 \\
.2 \\
.3 \\
0.2 \\
.2\end{array}$ & $\begin{array}{l}0.7 \\
.0 \\
0 \\
0 \\
0 \\
.4\end{array}$ & $\begin{array}{r}0.7 \\
1.8 \\
.9 \\
.5 \\
1.0 \\
.2\end{array}$ & $\begin{array}{r}13.8 \\
22.4 \\
6.4 \\
6.6 \\
19.7 \\
1.1\end{array}$ & $\begin{array}{l}0 \\
0 \\
0 \\
0_{0}^{.2} \\
0\end{array}$ & $\begin{array}{r}2.1 \\
5.8 \\
1.1 \\
.3 \\
2.3 \\
.6\end{array}$ & $\begin{array}{l}0 \\
0 \\
0 \\
0 \\
0 \\
0\end{array}$ & $\begin{array}{l}0 \\
0 \\
0 \\
0 \\
0 \\
0\end{array}$ & $\begin{array}{l}20.2 \\
17.0 \\
18.6 \\
18.2 \\
15.6 \\
15.7\end{array}$ & $\begin{array}{l}0 \\
.1 \\
0 \\
0 \\
1.6 \\
5.6\end{array}$ & $\begin{array}{l}0 \\
.1 \\
0 \\
.1 \\
2.6 \\
4.1\end{array}$ & $\begin{array}{l}0.1 \\
1.0 \\
0 \\
.5 \\
9.2 \\
4.6\end{array}$ & $\begin{array}{r}0.9 \\
6.5 \\
.1 \\
1.5 \\
11.2 \\
8.2\end{array}$ & $\begin{array}{r}13.2 \\
23.9 \\
6.8 \\
6.2 \\
16.0 \\
16.1\end{array}$ & $\begin{array}{r}19.2 \\
16.7 \\
24.2 \\
17.8 \\
9.3 \\
8.6\end{array}$ & $\begin{array}{r}16.5 \\
11.9 \\
21.9 \\
15.3 \\
7.2 \\
8.5\end{array}$ & $\begin{array}{l}9.1 \\
7.9 \\
8.8 \\
7.9 \\
4.8 \\
7.4\end{array}$ & $\begin{array}{r}6.2 \\
4.0 \\
6.3 \\
10.8 \\
4.9 \\
7.1\end{array}$ & $\begin{array}{r}12.0 \\
9.8 \\
8.9 \\
6.2 \\
8.6 \\
15.4\end{array}$ & $\begin{array}{l}17.1 \\
13.5 \\
15.4 \\
23.6 \\
16.3 \\
10.0\end{array}$ & $\begin{array}{l}1.8 \\
1.5 \\
2.1 \\
3.5 \\
2.0 \\
1.9\end{array}$ & $\begin{array}{l}\text { 3.9 } \\
3.0 \\
5.5 \\
6.6 \\
6.3 \\
2.5\end{array}$ \\
\hline $\begin{array}{l}0 \\
0 \\
0 \\
0\end{array}$ & $\begin{array}{l}0 \\
.2 \\
.2 \\
0\end{array}$ & $\begin{array}{r}.4 \\
.7 \\
.8 \\
1.0\end{array}$ & $\begin{array}{r}7.7 \\
7.5 \\
2.8 \\
15.5\end{array}$ & $\begin{array}{l}0^{2} \\
0 \\
.2\end{array}$ & $\begin{array}{r}1.3 \\
.7 \\
.8 \\
3.3\end{array}$ & $\begin{array}{l}0 \\
0 \\
0 \\
0\end{array}$ & $\begin{array}{l}0 \\
0 \\
0 \\
0\end{array}$ & $\begin{array}{l}15.8 \\
14.8 \\
26.2 \\
23.7\end{array}$ & $\begin{array}{l}0 \\
0 \\
0^{.2}\end{array}$ & $\begin{array}{l}\text { Tr. } \\
0 \\
0^{2}\end{array}$ & $\begin{array}{l}\text { Tr. } \\
0 \\
2.5 \\
0\end{array}$ & $\begin{array}{l}1.5 \\
.3 \\
9.0 \\
0\end{array}$ & $\begin{array}{r}7.3 \\
9.0 \\
18.1 \\
.7\end{array}$ & $\begin{array}{l}15.5 \\
17.9 \\
16.0 \\
10.8\end{array}$ & $\begin{array}{r}9.6 \\
15.3 \\
12.0 \\
24.6\end{array}$ & $\begin{array}{r}7.0 \\
11.0 \\
9.2 \\
17.8\end{array}$ & $\begin{array}{r}6.4 \\
7.4 \\
8.1 \\
12.7\end{array}$ & $\begin{array}{r}10.1 \\
7.7 \\
6.6 \\
8.4\end{array}$ & $\begin{array}{l}29.7 \\
23.6 \\
14.3 \\
17.5\end{array}$ & $\begin{array}{l}4.0 \\
1.7 \\
.8 \\
2.5\end{array}$ & $\begin{array}{l}\text { 8. } 9 \\
6.1 \\
\text { 3. } \\
\text { 5. } 0\end{array}$ \\
\hline $\begin{array}{l}0 \\
0 \\
0 \\
0 \\
0 \\
0\end{array}$ & $\begin{array}{l}0 \\
0^{2} \\
0 \\
0 \\
0\end{array}$ & $\begin{array}{l}.7 \\
.5 \\
.6 \\
.7 \\
.4 \\
.9\end{array}$ & $\begin{array}{r}15.1 \\
4.6 \\
6.3 \\
9.3 \\
2.2 \\
7.1\end{array}$ & $\begin{array}{l}0 \\
0 \\
0 \\
0^{.2} \\
.3\end{array}$ & $\begin{array}{r}2.9 \\
.7 \\
.2 \\
1.2 \\
.2 \\
1.9\end{array}$ & $\begin{array}{l}0 \\
0 \\
0 \\
0 \\
0 \\
0\end{array}$ & $\begin{array}{l}0 \\
0 \\
0 \\
0 \\
0 \\
0\end{array}$ & $\begin{array}{l}21.2 \\
29.9 \\
30.4 \\
29.0 \\
29.2 \\
32.7\end{array}$ & $\begin{array}{l}0 \\
0 \\
.1 \\
0 \\
0 \\
.4\end{array}$ & $\begin{array}{l}0 \\
0 \\
0 \\
0 \\
\text { Tr. } \\
1.5\end{array}$ & $\begin{array}{l}0 \\
0 \\
.4 \\
0 \\
.1 \\
4.5\end{array}$ & $\begin{array}{l}0 \\
\operatorname{Tr} . \\
.3 \\
0.3 \\
6.5\end{array}$ & $\begin{array}{r}1.1 \\
.5 \\
.3 \\
.1 \\
1.0 \\
13.1\end{array}$ & $\begin{array}{r}17.5 \\
20.5 \\
10.3 \\
.1 \\
6.7 \\
12.7\end{array}$ & $\begin{array}{r}27.2 \\
26.3 \\
10.5 \\
7.6 \\
16.7 \\
12.0\end{array}$ & $\begin{array}{r}11.4 \\
15.1 \\
13.1 \\
16.8 \\
13.1 \\
8.6\end{array}$ & $\begin{array}{r}8.5 \\
10.7 \\
19.5 \\
24.1 \\
11.4 \\
7.9\end{array}$ & $\begin{array}{r}7.8 \\
5.2 \\
7.6 \\
12.9 \\
6.7 \\
7.9\end{array}$ & $\begin{array}{l}20.7 \\
16.7 \\
27.8 \\
29.5 \\
34.7 \\
18.5\end{array}$ & $\begin{array}{l}1.4 \\
1.7 \\
3.0 \\
2.5 \\
3.0 \\
2.1\end{array}$ & $\begin{array}{l}4.4 \\
3.3 \\
7.0 \\
6.4 \\
6.3 \\
4.3\end{array}$ \\
\hline $\begin{array}{l}0 \\
0 \\
0 \\
0 \\
0\end{array}$ & $\begin{array}{l}0 \\
0^{\circ} \\
0 \\
0\end{array}$ & $\begin{array}{l}0 \\
1.5 \\
.2 .7 \\
2.7\end{array}$ & $\begin{array}{r}.5 \\
58.9 \\
1.7 \\
60.8 \\
68.8\end{array}$ & $\begin{array}{r}0 \\
.7 \\
.2 \\
3.8 \\
2.4\end{array}$ & $\begin{array}{l}0 \\
1.3 \\
.2 \\
1.6 \\
1.9\end{array}$ & $\begin{array}{l}0 \\
0 \\
0 \\
0 \\
0\end{array}$ & $\begin{array}{l}0 \\
0 \\
0 \\
0\end{array}$ & $\begin{array}{r}16.7 \\
12.6 \\
15.2 \\
9.7\end{array}$ & $\begin{array}{l}0 \\
0 \\
0 \\
0\end{array}$ & $\begin{array}{l}0 \\
0 \\
0 \\
0\end{array}$ & $\begin{array}{c}0 \\
0 \\
0 \\
\mathbf{T r} .\end{array}$ & $\begin{array}{l}0 \\
.1 \\
.1 \\
.1\end{array}$ & $\begin{array}{r}2.7 \\
5.2 \\
11.3 \\
17.9\end{array}$ & $\begin{array}{l}15.9 \\
15.2 \\
19.9 \\
36.4\end{array}$ & $\begin{array}{l}16.7 \\
14.0 \\
14.0 \\
10.9\end{array}$ & $\begin{array}{r}11.0 \\
10.5 \\
11.6 \\
6.9\end{array}$ & $\begin{array}{l}8.3 \\
8.6 \\
8.5 \\
5.9\end{array}$ & $\begin{array}{r}7.6 \\
10.7 \\
9.0 \\
5.3\end{array}$ & $\begin{array}{r}29.6 \\
26.0 \\
9.4 \\
13.6\end{array}$ & $\begin{array}{l}2.9 \\
3.2 \\
3.8 \\
1.2\end{array}$ & $\begin{array}{l}5.3 \\
6.5 \\
2.4 \\
1.8\end{array}$ \\
\hline $0^{\circ} .3$ & $0^{.5}$ & $\begin{array}{l}0^{-8} \\
1.8\end{array}$ & $\begin{array}{l}62.0 \\
14.0\end{array}$ & $\begin{array}{r}5.6 \\
.7\end{array}$ & $\begin{array}{l}.7 \\
1.8\end{array}$ & . 3 & $\begin{array}{l}1.7 \\
0 \\
0\end{array}$ & $\begin{array}{l}11.7 \\
21.1\end{array}$ & $\begin{array}{l}0 \\
0\end{array}$ & $\begin{array}{c}0 \\
\text { Tr. }\end{array}$ & $\begin{array}{l}0 \\
3.6\end{array}$ & $\begin{array}{c}0 \\
10.1\end{array}$ & $\begin{array}{r}.1 \\
13.4\end{array}$ & $\begin{array}{r}1.7 \\
12.3\end{array}$ & $\begin{array}{l}17.2 \\
10.6\end{array}$ & $\begin{array}{r}16.1 \\
8.9\end{array}$ & $\begin{array}{r}11.9 \\
9.3\end{array}$ & $\begin{array}{l}7.6 \\
6.1\end{array}$ & $\begin{array}{l}34.1 \\
19.4\end{array}$ & $\begin{array}{l}3.2 \\
2.5\end{array}$ & $\begin{array}{l}8.1 \\
3.8\end{array}$ \\
\hline $\begin{array}{l}.3 \\
.5 \\
.5\end{array}$ & $\begin{array}{l}0 \\
0 \\
0\end{array}$ & $\begin{array}{l}.5 \\
0.9 \\
1.9\end{array}$ & $\begin{array}{r}13.3 \\
3.3 \\
3.8\end{array}$ & $\begin{array}{l}1.1 \\
0 \\
4.5\end{array}$ & $\begin{array}{r}1.6 \\
.2 \\
.7\end{array}$ & $\begin{array}{l}.5 \\
0 \\
0\end{array}$ & $\begin{array}{l}0 \\
0 \\
0\end{array}$ & $\begin{array}{l}(3) \\
\text { (3) } \\
18.7\end{array}$ & 0 & 0 & 0 & 0 & 1 & 3.5 & 21.4 & 22.0 & 13.3 & 9.9 & 21.4 & 3.3 & 5.1 \\
\hline $\begin{array}{l}0 \\
0 \\
0 \\
0\end{array}$ & $\begin{array}{l}0 \\
0 \\
0 \\
0\end{array}$ & $\begin{array}{l}0 \\
8.6 \\
4.6 \\
3.9\end{array}$ & $\begin{array}{r}.5 \\
41.0 \\
34.9 \\
3.9\end{array}$ & $\begin{array}{c}0 \\
4.5 \\
12.8 \\
4.4\end{array}$ & $\begin{array}{l}0 \\
6.3 \\
3.6 \\
.6\end{array}$ & $\begin{array}{l}.5 \\
1.9 \\
5.1 \\
0\end{array}$ & $\begin{array}{l}0 \\
0 \\
0 \\
0\end{array}$ & $\begin{array}{r}18.3 \\
49.7 \\
34.4 \\
6.4\end{array}$ & $\begin{array}{l}0 \\
5.0 \\
0.3\end{array}$ & $\begin{array}{l}0 \\
6.7 \\
1.3 \\
0\end{array}$ & $\begin{array}{l}0 \\
7.1 \\
3.7 \\
0\end{array}$ & $\begin{array}{c}0 \\
6.8 \\
13.2 \\
0\end{array}$ & $\begin{array}{r}.1 \\
5.3 \\
10.1 \\
0\end{array}$ & $\begin{array}{c}10.8 \\
4.1 \\
9.5 \\
0\end{array}$ & $\begin{array}{r}18.9 \\
13.4 \\
7.8 \\
4.3\end{array}$ & $\begin{array}{r}15.4 \\
12.4 \\
7.5 \\
23.8\end{array}$ & $\begin{array}{r}12.1 \\
9.7 \\
7.4 \\
26.6\end{array}$ & $\begin{array}{l}10.2 \\
10.0 \\
12.9 \\
16.9\end{array}$ & $\begin{array}{l}23.9 \\
13.3 \\
22.0 \\
22.1\end{array}$ & $\begin{array}{l}4.3 \\
1.5 \\
3.1 \\
2.5\end{array}$ & $\begin{array}{l}4.3 \\
4.7 \\
1.2 \\
3.8\end{array}$ \\
\hline
\end{tabular}

3 Too firmly silica-cemented for mechanical analysis; sample crushed and separated for heavy-mineral analysis.

yellowish gray. In the lower part of the Cokedale, carbonaceous siltstone that contains abundant leaf impressions, pollen, and spores indicates a transition from brackish-water marine deposition of the Eagle Sandstone to continental deposition of the Cokedale. Locally, in the upper part of the formation, fresh-water mollusks are preserved.

Hard ridge-forming sandstone makes up about 35 percent of the formation. The sandstone beds are generally dusky yellow green, weathering to light olive; they are massive to thin bedded, crossbedded, fine to coarse grained, and locally conglomeratic. Many conglomeratic sandstones occur in scour-and-fill structures; mudstone fragments are common constituents of these deposits. Sandstone beds contain angular to subrounded grains of volcanic rock (predominantly microporphyritic and porphyritic andesite), plagioclase (andesine), heavy minerals, and quartz. The heavy minerals (in order of decreasing abundance) are diopsidic augite, magnetite, zircon, copper mineral, leucoxene, hematite, biotitemuscovite, epidote, pyrite, anatase, staurolite, hypersthene, sillimanite, garnet, sphene, corundum, tourmaline, and hornblende (table 6). Pebbles of volcanic rock include a distinctive welded tuff known to be indigenous only to the Elkhorn Mountains Volcanics west of this area (M. R. Klepper, oral commun., 1958). The oldest beds that contain these pebbles occur 600 feet above the base of the Cokedale Formation. Sandstone in the Cokedale contains much petrified wood and rare dinosaur bones. The sandstones are cemented mainly by silica, but the cement includes lesser amounts of calcite, zeolite minerals, and montmorillonitic clay. The dominant zeolite is heulandite, which commonly has a characteristic orange color.

Prominent beds of light-gray calcareous quartzose sandstone similiar to sandstone in the Eagle crop out 340 and 510 feet above the base of the Cokedale Formation (measured section 16); the uppermost sandstone is 16 feet thick and probably is the western tongue of the Parkman Sandstone of areas farther east (fig. 2). These sandstones are better sorted than other sandstones in the Cokedale and consist of 35 to 55 percent quartz grains and lesser amounts of plagioclase (andesine) and potassium feldspar (orthoclase). These sandstones also contain a heavy-mineral suite similar to that in the Eagle Sandstone at Cokedale. The heavy minerals (in 


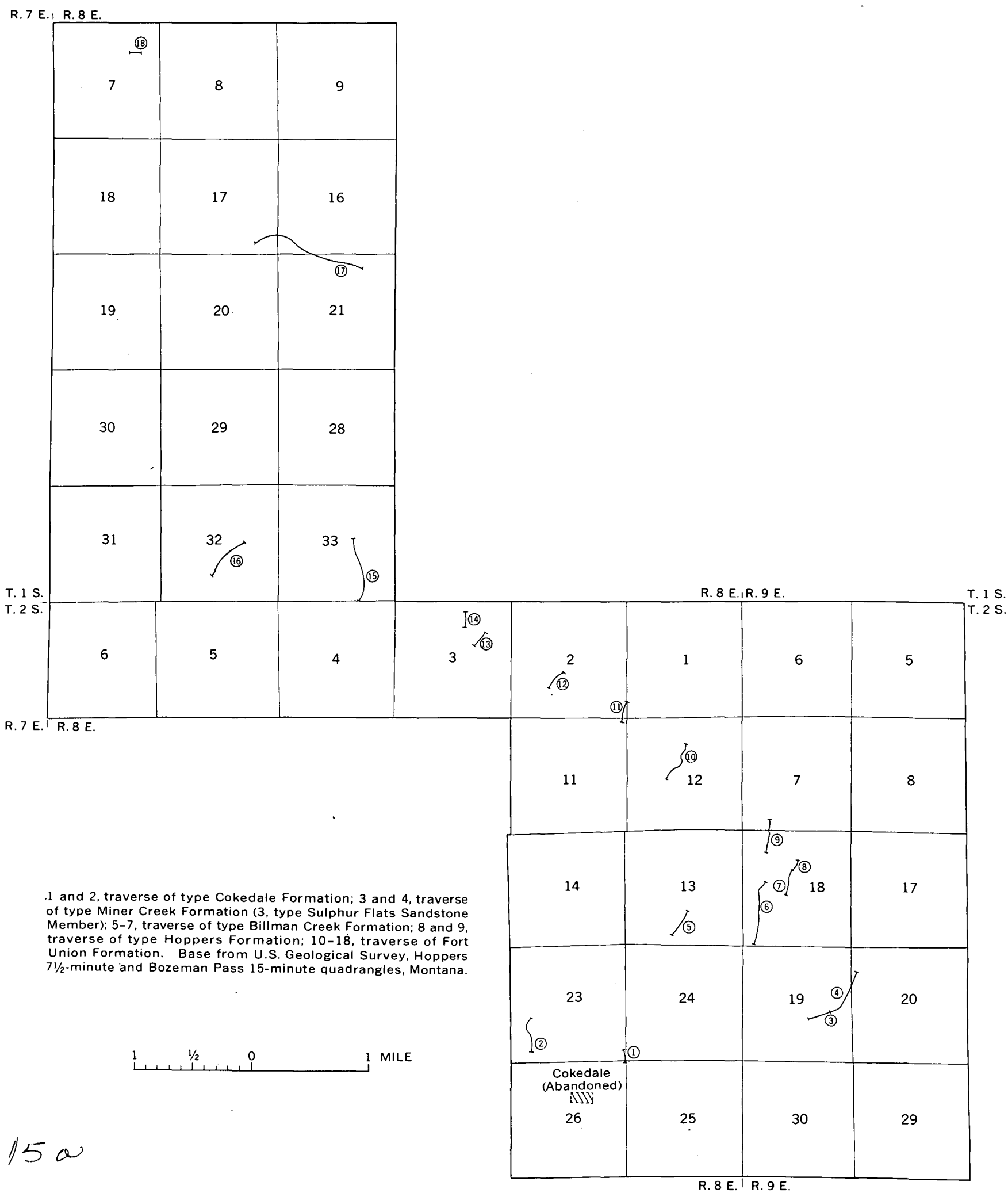

FIGURE 15.-Index map showing locations of measured units for the type Livingston Group and Fort Union Formation near Livingston, Mont. 


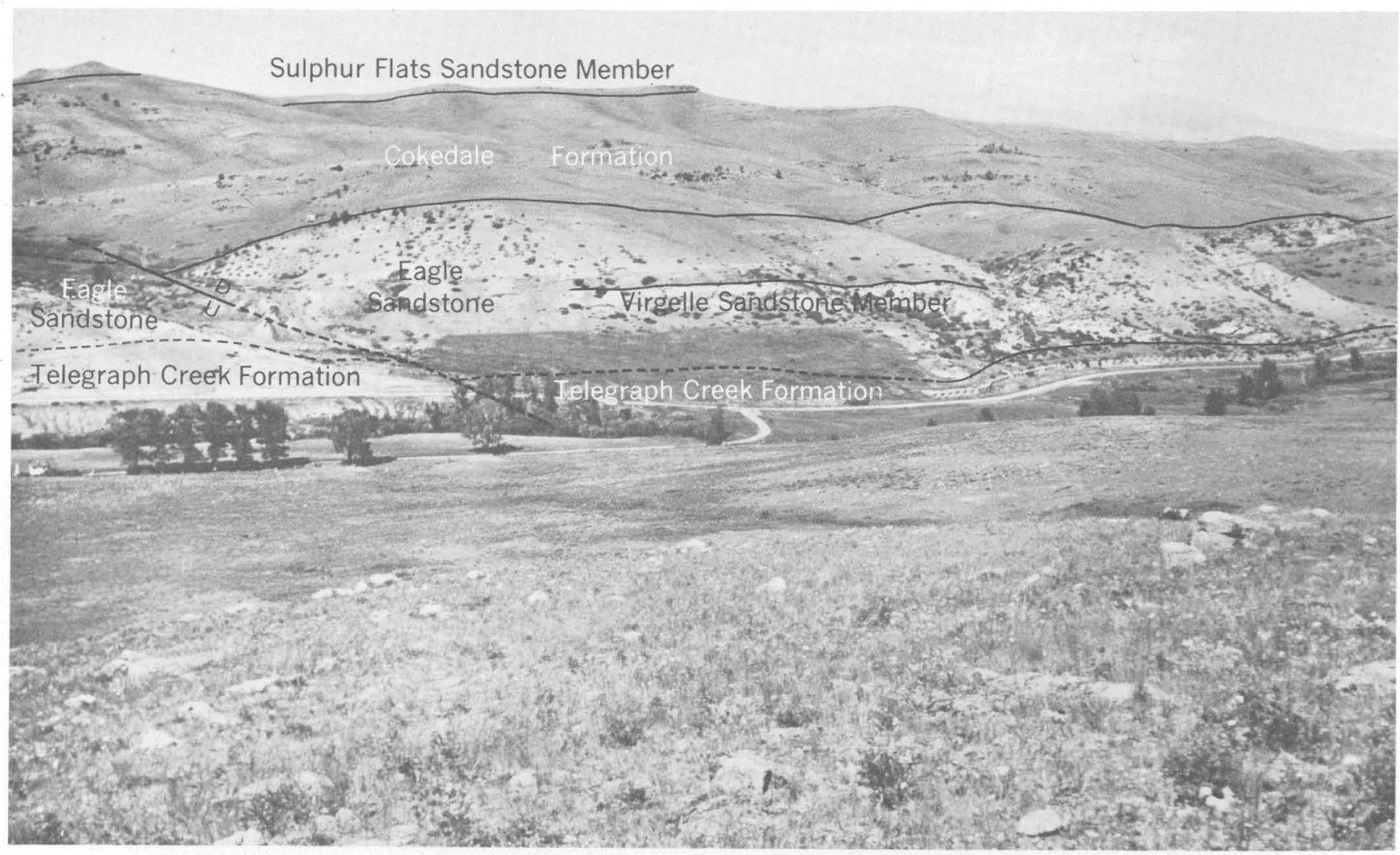

Frgure 16.-Type Cokedale Formation near the former coal-mining town of Cokedale, Mont. At this locality the Cokedale conformably overlies the coal-bearing Eagle Sandstone and is overlain by the ridge-forming Sulphur Flats Sandstone Member of the Miner Creek Formation.

order of decreasing abundance) are zircon, biotitemuscovite, hypersthene, epidote, tourmaline, diopsidic augite, copper, magnetite, leucoxene, sphene, sillimanite, staurolite, anatase, topaz, garnet, corundum, and hematite (table 6 ).

Age and Correlation

Mudstone and sandstone from 660 to 680 feet above the base of the Cokedale Formation in the SW1/4 sec. 23 , T. 3 S., R. 8 E., contain an abundant pollen and spore flora (table 4). According to R. H. Tschudy (written commun., 1962), this flora is definitely older than the flora in the Mitten Black Shale Member of the Pierre Shale and most nearly resembles the flora from the Blair Formation of the Rock Springs region, Wyoming.

Samples (D1815-1 and D4120) collected near the middle of the Cokedale yielded a palynomorph assemblage common to the type Claggett Shale and the lower part of the type Judith River Formation (R. H. Tschudy, oral commun., 1968). This flora (table 4) suggests a deltaic environment of deposition to Tschudy.

Fragments of ?Monoclonius sp. that commonly occur in the Judith River Formation in Montana and in the "Pale Beds" at the top of the Belly River Formation in
Alberta were identified by G. E. Lewis (written commun., 1963) from a sandstone 710 feet above the base of the Cokedale. The stratigraphic position of the Judith River Formation and its correlation with the Belly River Formation was first described by Hatcher and Stanton (1903).

In a siltstone bed (measured section 16, unit 167) 140 feet below the top of the Cokedale, the following freshwater snails were collected by the writer and identified by D. W. Taylor (written commun., 1962) :

Viviparus

cf. Lioplacodes tenuicarinata (Meek and Hayden) Physa?

The Cokedale Formation is the westward nonmarine equivalent of the Claggett Shale and part of the Judith River Formation of central Montana, or part of the Two Medicine Formation of northwestern Montana (fig. 2). The Cokedale is the lower part of the leaf beds member of Weed's (1893, p. 22) Livingston Formation.

Tuffs in the middle part of the Cokedale Formation are persistent laterally and may correspond to Member D of the Livingston Group at Maudlow, Mont. 
(Skipp and Peterson, 1965). Mapping in the Sedan quadrangle by B. A. Skipp and W. J. McMannis (oral commun., 1967) supports this correlation. Member D is a distinctive welded tuff unit similar to the welded tuffs of the middle member of the Elkhorn Mountains Volcanics. Robinson and Marvin (1967) compared the similar chemical composition and potassium-argon ages of the volcanic glass in these rocks. Radiometric studies by J. D. Obradovich (oral commun., 1968) indicate an age of 78 m.y. (million years) for the basal member of the Elkhorn Mountains Volcanics and $74 \pm 2$ m.y. for the Butte Quartz Monzonite that cuts the middle member of the Elkhorn Mountains Volcanics; an age of $76 \pm 2$ m.y. for the middle member of the Elkhorn Mountains Volcanics seems reasonable. This age is inferred for the middle part of the Cokedale Formation.

\section{MINER GREEK FORMATION}

The Miner Creek Formation was named by Roberts (1963, p. B90) for exposures along Miner Creek in the E $1 / 2$ sec. 19 and the NW1/4 sec. 20, T. 2 S., R. 9 E. (fig. 15). The Miner Creek in the type section conformably overlies the Cokedale Formation and is 1,350 feet thick. The Miner Creek consists largely of alternating beds of siltstone and sandstone (fig. 17). The basal unit consists of a prominent ridge-forming sandstone and interbedded silicified tuff 160 feet thick. This unit is called the Sulphur Flats Sandstone Member, named for the section exposed along Miner Creek near Sulphur Flats in the $\mathrm{SE} 1 / 4$ sec 19, T. 2 S., R. 9 E.

At Loweth, Mont., near the type Lennep Sandstone, J. R. Gill (oral commun., 1967) measured 785 feet of Miner Creek Formation overlying the Lennep Sand-

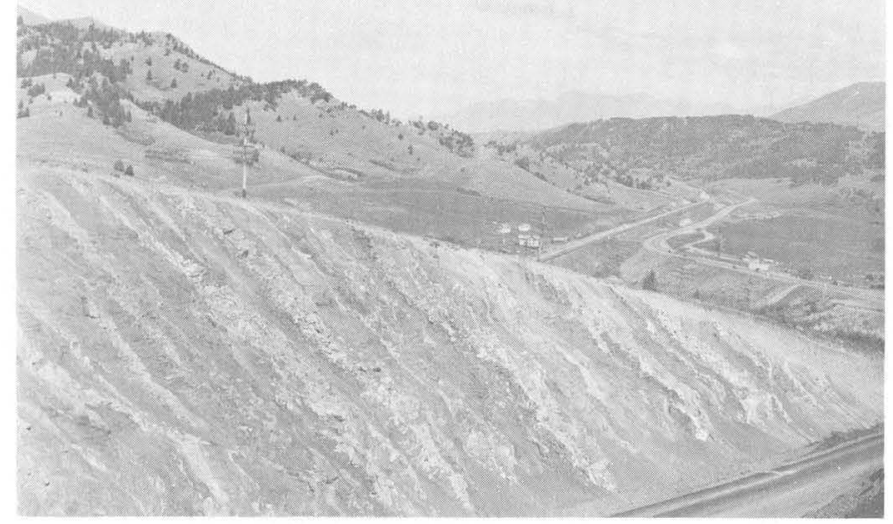

Figure 17.-Overturned sandstone and siltstone beds of the Miner Creek Formation exposed in roadcut at Bozeman Pass in the $\mathrm{NE}^{1} / 4$ sec. 13 , T. 2 S., R. $7 \mathrm{E}$. View is east. stone, and near Columbus, Mont., he measured 203+ feet of Miner Creek overlying the Lennep.

\section{Lithologic Composition}

The Miner Creek Formation consists of tuffaceous siltstone, volcanic lithic sandstone, volcanic sandstone, silicified tuff, and bentonite (measured section 17).

Massive-bedded tuffaceous siltstone forms 75 percent of the Miner Creek Formation. The siltstone in the upper part of the formation is olive gray and weathers to light olive gray. In the middle of the formation it is dusky yellow green and weathers to grayish yellow green, and in the lower part it is generally grayish olive green and weathers to grayish yellow green.

Sandstone forms about 20 pereent of the formation. The sandstones are generally well bedded, fine to medium grained, subangular, and poorly to moderately sorted. Sandstone of the Sulphur Flats Sandstone Member, however, is massive, crossbedded, and poorly sorted. The sandstones are grayish green, weathering to light olive gray.

The sandstones of the Miner Creek Formation are composed primarily of volcanic rock fragments and plagioclase, which occurs as oscillation-zoned crystals and as crystal fragments. Very little quartz and potassium feldspar are present. The plagioclase feldspar ranges from andesine to labradorite and the potassium feldspar is orthoclase. Rock fragments are devitrified glass, fine-grained andesite, porphyritic and microporphyritic andesite, chert, and a few quartzose rocks. The feldspar and rock fragments are highly altered to carbonate and clay minerals.

Magnetite and diopsidic augite contents exceed 1 percent. Hematite is abundant as an iron oxide stain and as disseminated grains. Heavy minerals present (in order of decreasing abundance) are diopsidic augite, magnetite, zircon, hornblende, epidote, copper mineral, biotite-muscovite, hypersthene, hematite, leucoxene, corundum, topaz, cassiterite, garnet, sillimanite, tourmaline, sphene, rutile, staurolite, pyrite, and anatase (table 6). Other minerals identified are chlorite, nontronite, calcite, and apatite.

The grains are cemented by calcite, silica, and zeolite minerals (generally heulandite and lesser amounts of analcime and laumontite). Some heulandite cement has an orange tint due to included fine hematitic dust.

$$
\text { Sulphur Flats Sandstone Member }
$$

The Sulphur Flats Sandstone Member consists mainly of tuff, quartzose sandstone, volcanic lithic sandstone, and conglomerate.

The tuffs are composed dominantly of plagioclase (laboradorite to andesine), volcanic rock fragments, 
and a clayey silt matrix. The distinguishable rock fragments are fine-grained andesites, porphyritic andesites, and devitrified glass. These fragments are generally very fine grained but contain plagioclase microlites, laths, and fragments dispersed in the matrix. An X-ray analysis of a water-laid tuff (measured section 17 , unit 9 ) indicates that it contains approximately 17 percent quartz. Other samples may contain more silica. The tuffs are commonly silicified and form indurated chert-like beds that are pale pink or green.

Zeolite minerals are characteristic of the Miner Creek Formation and are present in the Sulphur Flats Sandstone Member in quantities exceeding 1 percent. The zeolites are present as void fillings between grains and as cavity fillings ( 1 to 13 percent). Some have an orange tint due to fine hematitic dust dispersed through the zeolite. Optical properties and X-ray analysis indicate that the zeolites are predominantly heulandite; analcime, laumontite, and clinoptilolite are present in trace amounts.

The dominant clinopyroxene is diopsidic augite. Concentration of this mineral and clinoptilolite gives the formation a distinctive green color. The heavy minerals present (in order of decreasing abundance) are diopsidic augite, zircon, magnetite, epidote, biotite-muscovite, copper mineral, tourmaline, corundum, hornblende, hypersthene, staurolite, hematite, leucoxene, rutile, sphene, pyrite, topaz, garnet, and sillimanite (table 6 ). Biotite in the Miner Creek Formation and particularly in the Sulphur Flats Member, is abundant and characteristically light bronze in color.

Magnetite content exceeds 1 percent in nearly all beds in the Sulphur Flats Member (table 6), and it is generally concentrated along bedding laminations. Magnetite content in the Sulphur Flats Member increases northward from the type section. In this direction the nonmarine Sulphur Flats Sandstone Member grades laterally to the marine Lennep Sandstone. Magnetite and other heavy minerals are concentrated along the ancient strand line between these stratigraphic units. Such a sedimentary magnetite deposit can be observed near Wilsall, Mont., in sec. 25, T. 4 N., R. 8 E. Stebinger (1914a, p. 329-337) studied similar deposits in the Horsethief Sandstone (stratigraphic equivalent of the Lennep) in northwestern Montana and attributed those strata to deposition along ancient beaches. Houston and Murphy (1962), in a regional study of similar deposits, concluded that the magnetite-bearing sandstones were concentrated as placer deposits along the margin of an ancient shore line complex formed during the eastward regression of the Late Cretaceous sea. Stratigraphically above the Sulphur Flats Member, sandstone beds of the
Miner Creek Formation also contain concentrations of magnetite (table 6).

The basal and top sandstone beds of the Sulphur Flats Sandstone Member are distinctly different from other sandstone beds of the Livingston Group. The basal bed (measured section 17, unit 1) is a fine-grained calcareous mottled yellowish-gray quartzose sandstone, 6 to 20 feet thick. This excellent marker bed is persistent throughout the Livingston area. The sandstone is composed predominantly of quartz and contains lesser amounts of plagioclase (andesine), potassium feldspar, and bronze biotite; it is cemented by silica and zeolite minerals. A few volcanic rock fragments are also present. Sand grains are subangular to subrounded and moderately sorted. The basal sandstone is similar in mineralogy, grain size, color, mottling, sorting, and calcareous and zeolite cement to sandstone units of the Lennep Sandstone at Loweth, Mont. The mottling is due to differential weathering of less resistant calcareous material between clusters of zeolite minerals in the cement. At the top of the Sulphur Flats Member, indurated sandstone beds that form ridges are composed predominantly of subangular volcanic rock fragments and contain lesser amounts of plagioclase (andesine) crystals (measured section 17, unit 43). The fragments include a variety of volcanic debris; however, porphyritic and microporphyritic andesite and devitrified glass are most common. The sandstone is fine to coarse grained, poor to moderately sorted, and commonly crossbedded.

\section{Age and Correlation}

Stanton (in Stone and Calvert, 1910, p. 665) identified a Late Cretaceous marine fauna from sandstone assigned by Stone and Calvert to the Livingston Formation near Wilsall, Mont., in the NE1/4 sec. $25, \mathrm{~T} .4 \mathrm{~N}$., R. $8 \mathrm{E}$. The sandstone at this locality occupies a sandy transitional zone between the Bearpaw Shale and the overlying Lennep Sandstone. J. R. Gill and the writer visited this locality (USGS Mesozoic loc. D3082) and obtained the following fossils identified by W. A. Cobban:

Calcareous worm tube: Serpula sp.

Pelecypods :

Pteria nebrascana (Evans and Shumard)

Pteria ef. P. linguaeformis (Evans and Shumard)

Ostrea cf. O. russelli Landes

Crenella n. sp.

Tancredia americana (Meek and Hayden)

Callistra? sp.

Mactra ef. M. alta Meek and Hayden

Panope sp.

Cephalopods :

Baculites cf. B. compressus Say

Placenticeras meeki Boehm 
Only one baculite fragment was complete enough to suggest a species assignment. According to W. A. Cobban (written commun., 1961), this fragment most closely resembles an ornate variety of Baculites compressus, and the collection would be in the Baculites compressus zone or possibly the slightly younger Baculites cuneatus zone in the upper Campanian of Late Cretaceous age (fig. 2). The marine rocks from which these fossils were obtained can be traced from Wilsall northward into the type section of the Lennep Sandstone at the north end of the Crazy Mountains (J. R. Gill, oral commun., 1962). East of Livingston at Columbus, Mont., the Bearpaw Shale contains Baculites reesidei (W. A. Cobban, oral commun., 1968) indicating a younger age and marine environment for these rocks in that direction. South of Wilsall, in the Livingston area, these beds are represented by the nonmarine Sulphur Flats Sandstone Member of the Miner Creek Formation.

Near the close of Cokedale deposition the Bearpaw sea transgressed westward across the Crazy Mountains basin to the longitude of Wilsall, Mont. (fig. 2). Perhaps a decrease in the elevation and amount of erosion from the source area and (or) a slight uplift of the basin permitted marine deposition in the western part of the basin. When the Bearpaw sea subsequently withdrew eastward from the Crazy Mountains basin, the nonmarine Sulphur Flats Sandstone Member of the Miner Creek Formation and the marine Lennep Sandstone were deposited as regressive units.

In the area between Augusta and Wolf Creek, Mont., the St. Mary River Formation overlies the Horsethief Sandstone as shown in figure 2. The St. Mary River Formation is a thick sequence of continental rocks derived from a volcanic terrane, probably the Elkhorn Mountains Volcanics. The St. Mary River Formation closely resembles the upper part of the Livingston Group and can be similarly subdivided. The lower 1,200 feet of the St. Mary River Formation consists of greenish-gray sandstones and mudstones similar to the Miner Creek Formation. Overlying this lower member is 1,000 to 3,000 feet of grayish-red mudstone very similar to the Billman Creek Formation. Approximately 900 feet of volcanic sandstone similar to the Hoppers Formation overlies the grayish-red mudstone member.

A carbonaceous claystone 420 feet above the base of the Miner Creek Formation in sec. 19, T. 2 S., R. 9 E. (USGS Paleobotany loc. D1612) and a similar claystone 1,330 feet above the base of the Miner Creek in sec. 20, T. 2 S., R. 9 E. (USGS Paleobotany loc. D1613; table 4) contain a diagnostic pollen and spore flora ( $R$. H. Tschudy, written commun., 1967). The genus of greatest stratigraphic significance in these samples is
Aquilapollenites, of which the following species were found in the two samples: Aquilapollenites attenuatus, A. polaris, A. calvus, and A. reticulatus. Aquilapollenites calvus and $A$. polaris are species whose ranges include the Campanian and Maestrichtian. Aquilapollenites attenuatus and $A$. reticulatus have ranges limited to the upper one-fourth of the Campanian and the Maestrichtian. The pollen assemblage is closely similar to that of a zone rich in Aquilapollenites in the upper part of the Pierre Shale. The plant microfossils in samples from USGS Paleobotany localities D1612 and D1613 correlate with those in the upper part of the type Judith River Formation.

The Miner Creek Formation correlates eastward with the lower part of the Hell Creek Formation; and the basa lsandstone unit, the Sulphur Flats Sandstone Member, is the nonmarine facies of the marine Lennep Sandstone and the Horsethief Sandstone (fig. 2). The Miner Creek is the upper part of Weed's leaf beds (1893), p. 22).

\section{BILLMAN CREEK FORMATION}

The Billman Creek Formation was named by Roberts (1963, p. B91) for the nonmarine section exposed near Billman Creek in the $\mathrm{S} 1 / 2$ sec. 13, T. 2 S., R. 8 E., and the W $1 / 2$ sec. 18 , T. 2 S., R. 9 E. (measured sections $5-7$; fig. 15). The Billman Creek at the type section conformably overlies the Miner Creek Formation and is 2,590 feet thick. The Billman Creek is mostly mudstone but includes lesser amounts of sandstone, siltstone, claystone, and conglomerate (fig. 18). It is less resistant to weathering than adjacent formations and generally forms valleys. Throughout the western part of the Crazy Mountains basin, the formation is characteristically and conspicuously grayish red.

Weathering of volcanic deposits, which probably included a large volume of ash, west of Livingston during a period of reduced aggradation in the source area is suggested as the cause for this red-bed sequence.

\section{Lithologic Composition}

The Billman Creek Formation consists of alternately bedded mudstone, claystone, siltstone, and sandstone (measured section 18). Mudstone and claystone make up about 65 percent of the Billman Creek Formation and are commonly massive bedded and generally tuffaceous. Three representative samples of claystone average 40 percent montmorillonite, 50 percent mixedlayer montmorillonite-illite-vermiculite, 5 percent illite, and 5 percent chlorite (L. G. Schultz, oral commun., 1962). Mudstone and claystone in the upper part of the formation are olive black to olive gray and weather to light olive gray; in the middle part they are mostly grayish brown and weather to pale yellowish brown; 


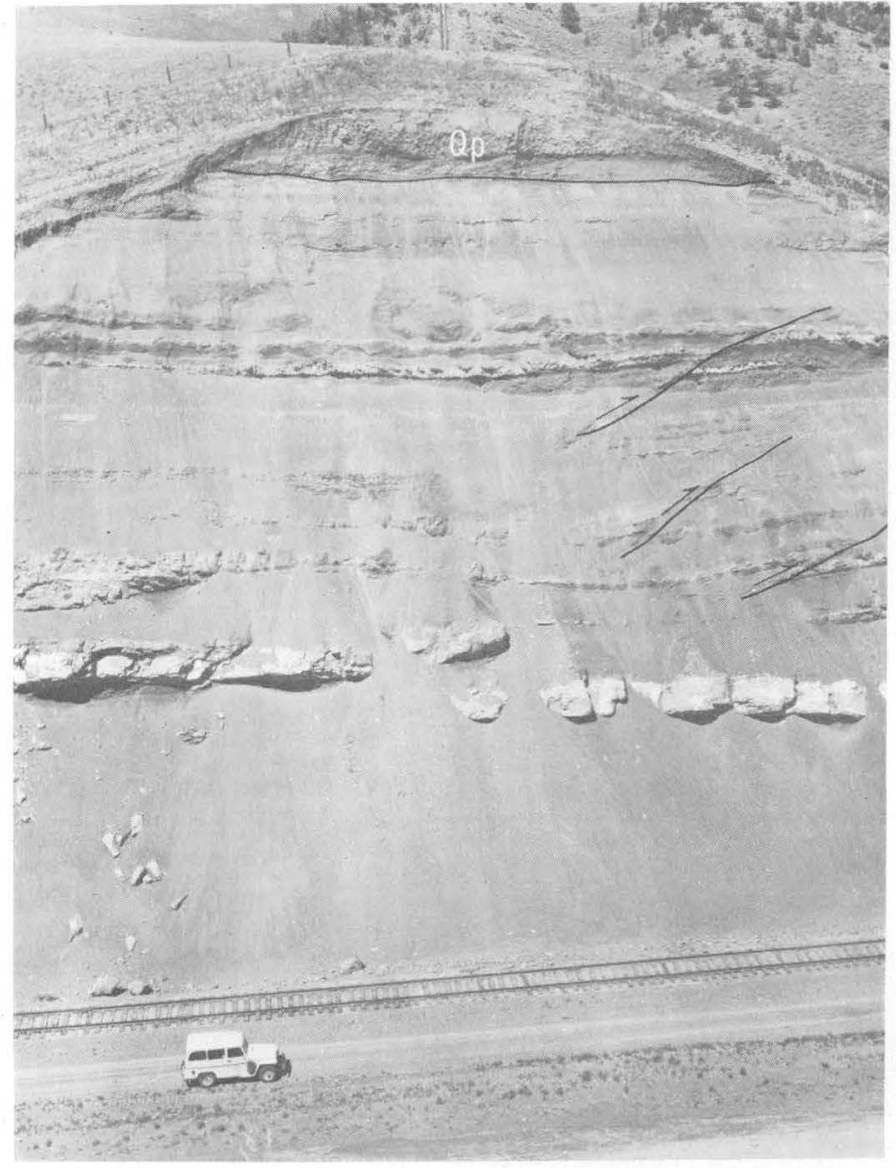

Figure 18.-Massive mudstones interbedded with sandstones and claystones typical of the Billman Creek Formation, exposed in large railroad cut in NE1/4 sec. 15, T. 2 S., R. 8 E. The formation at this locality is overlain by a Quarternary pediment deposit $(Q p)$. Note several small thrust faults; indicated direction of thrust is east.

and in the lower part they are mainly dusky red and weather to grayish red. Some beds in the lower part are grayish green, weathering to grayish yellow green. These multicolored very thick mudstones, particularly the grayish-red beds, characterize the Billman Creek Formation.

Sandstone and conglomerate channel fillings make up about 25 percent of the formation. These rocks are generally dusky yellow green and weather to grayish yellow green; they are composed of volcanic rock fragments, plagioclase (andesine), diopsidic augite, hornblende, magnetite, biotite, quartz, and orthoclase and are cemented by silica, calcite, clay, or zeolites. A 20foot-thick persistent andesitic sandstone unit 95 feet above the base of the Billman Creek Formation contains abundant spherical calcareous sandstone concretions, generally 1 to 2 feet in diameter, and is an excellent marker bed (fig. 19).

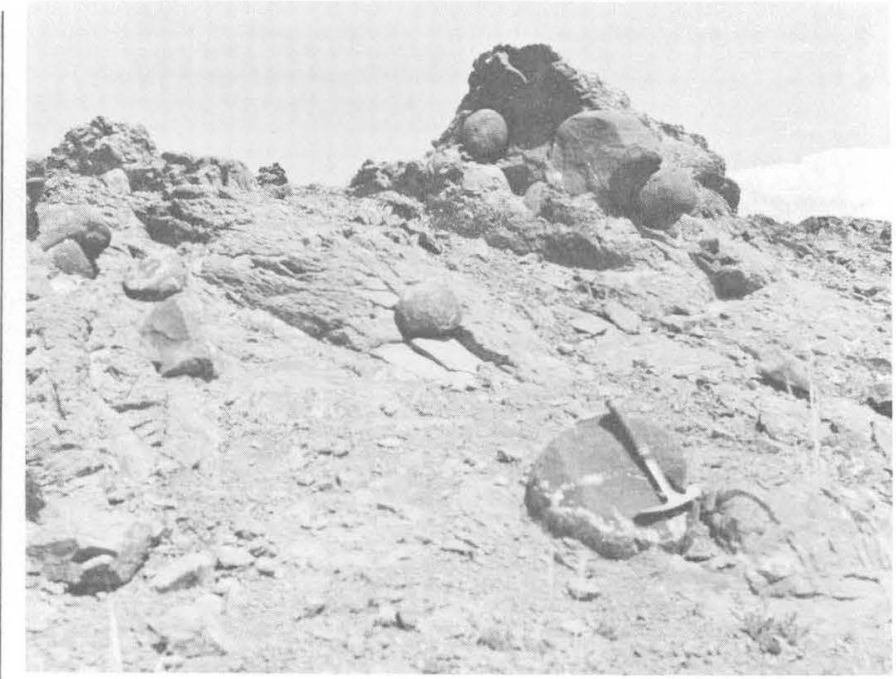

Figure 19.-Massive to crossbedded andesitic sandstone 95 feet above the base of the Billman Creek Formation in the NE1/4 sec. 19 , T. 2 S., R. 9 E. Unit contains abundant spherical caleareous concretions which are persistent laterally.

The sandstones are composed predominantly of feldspar (3-17 percent) and rock fragments (20-80 percent). The feldspars include orthoclase and plagioclase (generally andesine) and are generally altered, some completely to clay. Quartz is present in amounts less than 10 percent. The rock fragmetns are fine-grained andesite and microporphyritic and porphyritic andesite. Many of these fragments are stained with hematite Many of these fragments are stained with hematite. The sand grains are very fine to medium, mainly subangular, and poorly to moderately sorted. The grains are cemented by calcite, silica, clay, and zeolite minerals, generally heulandite.

Diopsidic augite and magnetite are present in quantities exceeding 1 percent. The heavy minerals present (in order of decreasing abundance) are diopsidic augite, magnetite, zircon, hypersthene, hematite, sphene, leucoxene, biotite-muscovite, hornblende, garnet, epidote, copper mineral, corundum, and staurolite (table 6). Other minerals present are sericite, chlorite, and nontronite.

\section{Age and Correlation}

At the base of the upper third of the Billman Creek Formation a massive brownish-gray mudstone (measured section 18, unit 105) contains sporadic small calcareous concretions and fresh-water mollusks and gastropods. The mudstone yielded a distinct palynomorph assemblage (table 4) equivalent to microflora found in the type Colgate Member of the Fox Hills Sandstone at Glendive, Mont. (R. H. Tschudy, oral commun., 1968). A siltstone (measured section 18, unit 137) near the top of the Billman Creek contains macerated plant frag- 
ments and a poor palynomorph assemblage of Cretaceous age that suggests deposition in a brackish-water environment (R. H. Tschudy, oral commun., 1968).

Dinosaur bones of Maestrichtian (Lancian) age were described from several localities in the upper part of the Billman Creek Formation 13 miles east of Bozeman, Mont., by McMannis (1955, p. 1408).

The following fresh-water mollusks were collected from the middle part of the Billman Creek (measured section 18 , unit 105 ) by the writer and identified by $\mathrm{D}$. W. Taylor (written commun., 1962) :

Fresh-water clams:
Sphaerium?
Unionidae indet.
Fresh-water snails :
Viviparus sp.
cf. Lioplacodes tenuicarinata (Meek and Hayden)
Physa sp.

According to Taylor, these species are known from much of the Cretaceous and could not be precisely dated but were in accord with a Late Cretaceous age assigned on the basis of plant microfossils and fossil vertebrates.

The Billman Creek Formation is approximately the same age as the middle part of the Hell Creek Formation in central Montana (fig. 2). The Billman Creek is in the lower part of the conglomerate member of Weed's (1893, p. 30) Livingston Formation.

\section{HOPPERS FORMATION}

The Hoppers Formation is a nonmarine unit named by Roberts (1963, p. B91) for exposures near Hoppers Siding on the Northern Pacific Railway in the SW1/4 sec. 7 , and the NW $1 / 4$ sec. 18, T. 2 S., R. 9 E. (fig. 15). The Hoppers Formation at the type section conformably overlies the Billman Creek Formation and is 965 feet thick. The Hoppers consists largely of massive sandstone beds that form valley walls above the easily eroded Billman Creek Formation.

\section{Lithologic Composition}

The Hoppers Formation is dominantly a volcanic lithic sandstone interbedded with mudstone and siltstone (measured section 19). Ridge-forming sandstone makes up 60 percent of the Hoppers Formation. The sandstone ranges from massive to thin bedded and is generally crossbedded. It is dusky yellow green and generally weathers olive gray; however, the basal 140 feet weathers a conspicuous yellowish gray and weathers to massive spheroidal shapes. The sandstones are mainly composed of quartz (7-12 percent) ; feldspar (10-22 percent, including orthoclase and plagioclase, generally andesine); and rock fragments (20-35 percent). The plagioclase composition is questionable due to intense alteration to clay. Rock fragments are fine-grained andesite, microporphyritic and porphyritic andesite, chert, and quartzite. The quartz has straight to strongly undulose extinction, and the grains have a few vacuoles and inclusions. The grains are cemented by calcite, silica, and zeolite minerals. The zeolite mineral is generally heulandite that has an orange tint due to inclusions of dispersed hematitic dust. The sandstone is fairly uniform in grain size (table 6) and moderately to well sorted. Grains are subangular to subrounded.

Much of the sandstone occurs as channel-fill deposits, which contain pebbles of mudstone and volcanic rock and fragments of wood and other plant debris. The basal sandstone beds of the Hoppers are massive, crossbedded, calcareous, generally conglomeratic, and cliff forming. Thin layers of ferromagnesian minerals, particularly magnetite, are common in these beds.

Clinopyroxene (dominantly diopsidic augite) and magnetite contents in two of the sandstone samples exceed 1 percent. Magnetite is concentrated in zones which accentuate bedding laminations. Heavy minerals present (in order of decreasing abundance), are diopsidic augite, magnetite, zircon, hematite, hypersthene, corundum, sphene, biotite-muscovite, epidote, leucoxene, hornblende, garnet, copper mineral, and staurolite (table 6). Other minerals present are nontronite, chlorite, and allanite.

About 25 percent of the formation is massive-bedded mudstone, which is olive gray and weathers to light olive gray. A few beds contain calcareous claystone concretions, and one was found that contains fresh-water mollusks.

Siltstone, which forms about 15 percent of the formation, is generally gradational with sandstone and is similar in color and mineral composition.

\section{Age and Correlation}

Fossils are rare in the Hoppers Formation, and the few that were found are not very helpful for precise dating. A massive siltstone (measured section 19, unit 42 ) in the upper part of the Hoppers yielded poorly preserved palynomorphs. According to R. H. Tschudy (oral commun., 1968) the presence of Araucariacites, code species $\mathrm{V}_{2} \mathrm{~S}-\mathrm{r} 6$, Classopollis, and Vitreisporites suggests a Cretaceous age for this unit, and the presence of hystrichospheres and dinoflagellates suggests brackish-water depositional conditions.

In a dark-brown calcareous siltstone 395 feet from the top of the formation (measured section 19, unit 35), the following fauna was collected by the writer and identified by D. W. Taylor (written commun., 1962) :

Fresh-water clam :

Rhabdotophorus aldrichi (White) 
Fresh-water snails:

Viviparus meeki Wenz

Lioplacodes indet.

According to Taylor, both Rhabdotophorus aldrichi and Viviparus meeki are known from the latest Cretaceous through the Eocene.

The Hoppers Formation correlates approximately with the upper part of the Hell Creek Formation of central Montana (fig. 2). The Hoppers is in the lower part of Weed's (1893, p. 30) conglomerate member.

\section{CRETACEOUS AND TERTIARY SYSTEMS \\ UPPER CRETACEOUS AND PALEOCENE SERIES}

\section{FORT UNION FORMATION}

The Fort Union Formation of Late Cretaceous and Paleocene age (Roberts, 1963, p. B89) overlies the type Livingston Group with apparent conformity. The Fort Union at Livingston, Mont., is a nonmarine sequence 6,615 feet thick (fig. 20) and consists of sandstone and conglomerate alternately bedded with siltstone and mudstone. It is subdivided into a lower conglomeratic sandstone member 980 feet thick, a middle member of sandstone and mudstone 3,835 feet thick, and an upper conglomeratic sandstone member 1,800 feet thick. The top is the present ground surface. These designations are somewhat general because the units vary considerably in average grain size and they are lenticular. The bedding and sedimentary structures of these rocks suggest flood-plain deposits on an extensive alluvial piedmont alternating with delta deposits in lakes. The source of the sediments was predominantly west of the Crazy Mountains basin; lesser amounts of sediment came from northwest and south of the basin.

The lithology of the rocks at the base of the Fort Union Formation differs markedly from the rocks of the underlying Livingston Group. Clasts in conglomerates of the Livingston are almost exclusively volcanic rock, whereas the conglomerates in the Fort Union contain igneous, metamorphic, and sedimentary clasts derived from Precambrian, Paleozoic, and Mesozoic formations. This significant change in provenance of the rocks, from a monolithologic to a heterolithologic unit, and an increase in fragment size suggest that the Fort Union Formation had a closer source area of additional relief and lithology subjected to greater erosion than did rocks of the Livingston Group. The lithology and size of clasts in the conglomeratic sequence at the base of the Fort Union indicate that the source area was probably a part of the Bridger uplift, which at this time was probably a broad feature that included most, if not all, of the Gallatin Valley. The abrupt change in lithology might indicate a short hiatus at the top of the Livingston; however, geologic mapping and similar spores and pollen immediately above and below

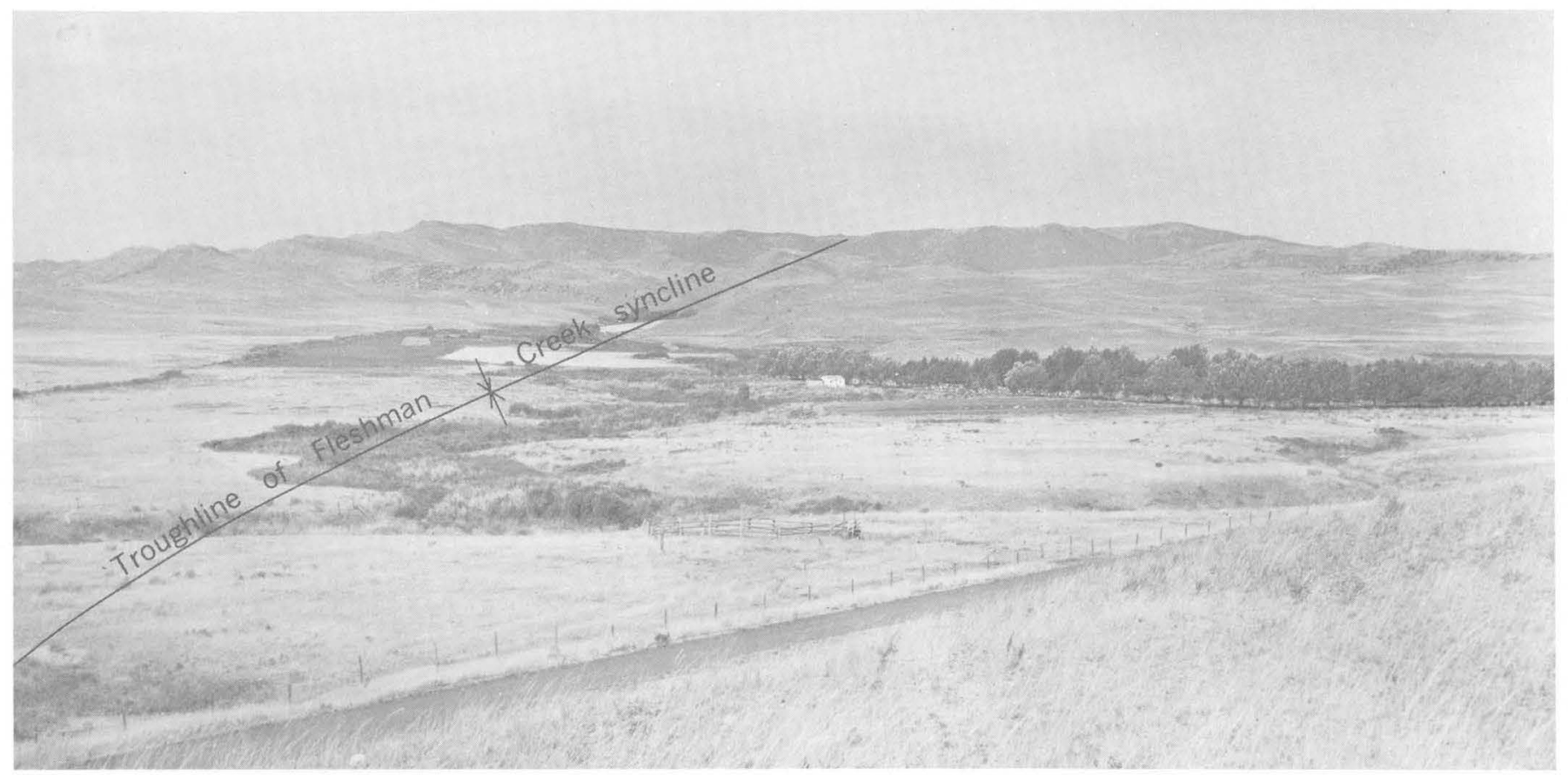

Figure 20.-Maximum thickness of the Fort Union Formation near the axis of the Fleshman Creek syncline. Reference section 20 was measured along the ridges at the left side of the photograph. View is northwest, parallel to the synclinal axis, from near Livingston, Mont. 
the Fort Union-Livingston contact support a conformable designation.

Brown (1949) prepared a reconnaissance map of the contact between strata he assigned to the Cretaceous and those he assigned to the Paleocene around the edge of the Crazy Mountains basin.

\section{LITHOLOGIG GOMPOSITION}

The thick sequence of continental sedimentary rocks of the Fort Union Formation includes coarse- to finegrained clastic strata that vary rapidly in lithology and other characteristics (measured section 20). Massive conglomerates are common in the Fort Union in the westernmost part of the Crazy Mountains basin and are thickest, coarsest, and most abundant near the east flank of the Bridger Range (fig. 21). Cobbles and pebbles in the conglomerates are dominantly porphyritic and microlitic andesite but include lesser amounts of Precambrian igneous and metamorphic rock and Paleozoic and Mesozoic sedimentary rock. The conglomeratic units thin progressively eastward and southeastward by grading and interfingering laterally with sandstone, and the sandstones merge in turn with the finer grained clastic rocks in the central part of the basin.

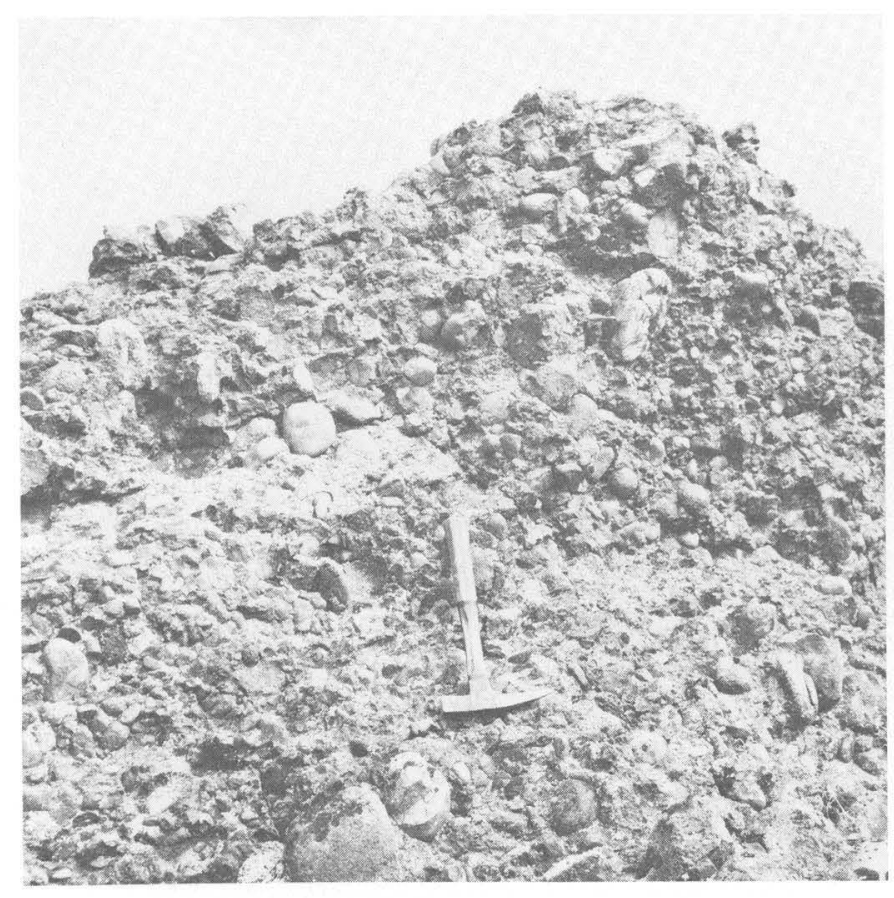

Figure 21.-Basal part of the upper conglomeratic sandstone member of the Fort Union Formation at Grassy Mountain in sec. 21, T 1 N., R. 7 E. Cobbles and pebbles are dominantly porphyritic and microlitic andesite with lesser amounts of Precambrian igneous and metamorphic rock and Paleozoic and Mesozoic sedimentary rock. Photograph by W. J. McMannis.
The sandstone units of the Fort Union Formation commonly are crossbedded or cross laminated and lenticular. Most of the crossbeds are foreset beds. In contrast, conglomerate units within the Fort Union are laterally extensive and apparently were deposited on a nearhorizontal surface.

Most sandstone beds within the Fort Union Formation contain some interbedded conglomerate. Sandstones in scour-and-fill structures commonly contain scattered mudstone pebbles, which are tabular fragments of laminated mudstone that generally have rounded edges. Most mudstone pebbles were apparently derived from underlying beds or from the sides of the channels during periodic torrential floods. Exposed surfaces of these deposits have characteristic indentations or cavities because the mudstone fragments weather out more readily than the enclosing sandstone.

One striking characteristic of the Fort Union Formation near Livingston is a cyclic alternation of sandstone and mudstone (pl. 2; measured section 20) in graded beds. Thick- to thin-bedded sandstone units are commonly coarse grained in the lower part and grade upward to fine grained at the top. Bedding in these sandstone units changes gradually from thick bedded at the base to thin bedded in the upper part; also, these sandstone units become better sorted and more calcareous progressively upward.

Most of the calcareous sandstone beds weather dark yellowish brown or brownish gray, whereas the noncalcareous beds weather light olive gray or grayish yellow green. The calcareous or slightly calcareous beds and the coarser grained conglomerate beds form ridges, whereas the noncalcareous beds and the finer grained sandstone and mudstone form slopes. In general, sandstones in the Fort Union become gradually lighter colored toward the top of the formation.

The sandstone units contain a large quantity of feldspar and lithic fragments of volcanic, metamorphic, and sedimentary rock; the grains are angular to subrounded. Samples examined for grain-size distribution indicate poor sorting (table 6). Feldspars include both orthoclase and plagioclase; the latter ranges in composition from andesine to labradorite. The cement consists of varying amounts of silica, calcite, or zeolite mineral.

The heavy minerals present (in order of decreasing abundance) are diopsidic augite, magnetite, zircon, hypersthene, garnet, hematite, epidote, sphene, leucoxene, biotite-muscovite, hornblende, corundum, rutile, staurolite, tourmaline, anatase, topaz, and copper mineral (table 6). Other minerals present are quartz, nontronite, chlorite, and zeolite. Quartz grains that have straight to strongly undulose extinction and a few 
vacuoles or inclusions suggest a possible metamorphic source for some of the sedimentary rock.

\section{AGE AND CORRELATION}

The lower part of the Fort Union Formation near Livingston, Mont., was assigned to the uppermost part of the Late Cretaceous by Roberts $(1963$, p. B89; 1965, p. B60). This assignment was based on paleontological data and tectonic implications of the rock types in the basal conglomeratic member of the Fort Union compared with conglomerates of the Livingston Group. Correlations and stratigraphic relations of the Fort Union at Livingston and adjacent areas are shown in figure 22.

Formations of the Livingston Group and members of the Fort Union Formation in the western part of the
Crazy Mountains basin are so similar that it is difficult to distinguish one from the other. Weed (1893, p. 35) recognized the Fort Union Formation on the east side of the Crazy Mountains; however, on the west side of the Crazy Mountains near Livingston he included the Fort Union in his Livingston Formation. Weed (1893, p. 31) was well aware that his upper (conglomerate) unit might be separated from underlying rocks with additional field studies and that it probably correlated with the Fort Union. Later (Iddings and Weed, 1894), the Fort Union was included in the underlying Livingston Formation in the southern half of the Crazy Mountains basin. Stone and Calvert (1910, p. 555) were able to trace Upper Cretaceous formations westward along the Musselshell River in the northeastern part of the basin and show that these forma-

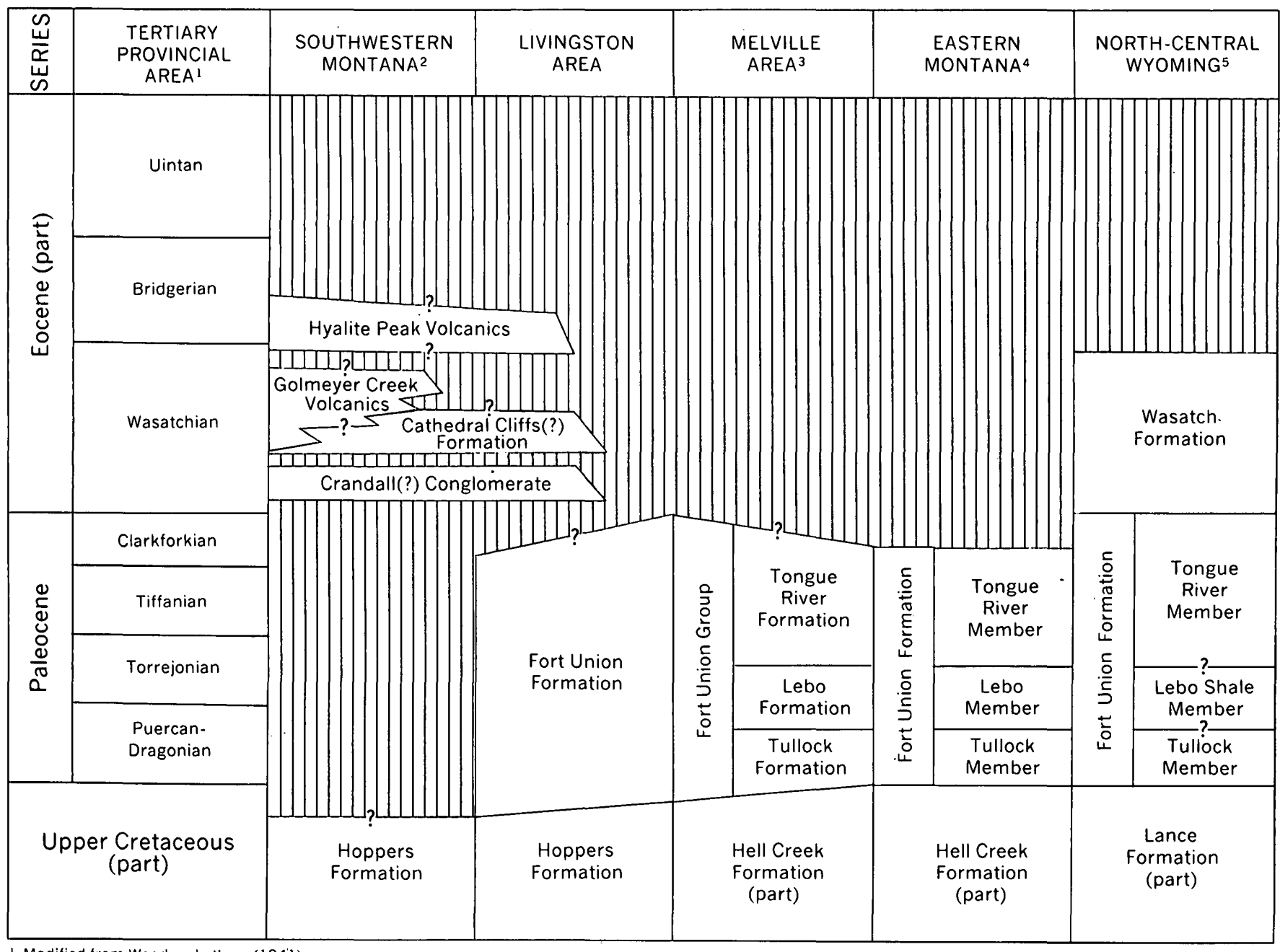

1 Modified from Wood and others (1941).

2 Modified from Pierce (1957; 1963); Chadwick (1969).

3 Modified from Simpson (1937); Stow (1946)

4 Modified from Brown (1962).

5 Modified from Mapel, Robinson, and Tehobald (1959).

F'iquRE 22.-Correlation and stratigraphic relations of part of the lower Tertiary rocks of the Livingston area, Montana, with rocks of other areas in Montana and Wyoming. 
tions grade into Weed's Livingston Formation. They demonstrated that Weed's Livingston Formation is a highly volcanic facies of the Claggett, Judith River, Bearpaw, Lennep, Lance (Hell Creek), and Fort Union Formations. Stone and Calvert (1910, p. 746) subdivided the Fort Union Formation near Harlowton, Mont., into two members and named the basal unit the Lebo Andesitic Member. Stone and Calvert (1910, p. $659)$ tentatively correlated the well-formed conglomerate on Brackett Creek on the east side of the Bridger Range (upper conglomeratic sandstone member) with light-colored sandstones near Clyde Park, Mont., that contained a Fort Union flora.

In the northeast part of the Crazy Mountains basin near Melville, Mont., Simpson (1937, p. 16-20), separated a Cretaceous-Tertiary transitional unit between what he defined as Hell Creek and Fort Union Formations and named the unit the Bear Formation. He assumed that beds up to and including the true dinosaur-bearing Lance and Hell Creek faunas belong in the Cretaceous and that overlying beds without dinosaurs (except by redeposition), but with Tertiary-type mammals, are Tertiary. His Bear Formation was given separate formational rank because it contained no diagnostic vertebrates and could not positively be included in either the Hell Creek or Fort Union; however, Simpson $(1937$, p. 21) favored inclusion with the Fort Union. The basal 80 feet of the Bear Formation (Simpson, 1937 , p. 17) contained fragmentary dinosaur specimens which he interpreted as being redeposited from eroded underlying Hell Creek beds. The arbitrary top of the Bear Formation (Simpson, 1937, p. 17) was assigned to a 1-foot-thick bed that contains a freshwater invertebrate fauna. This fauna was presumed to be of Paleocene age. However, later studies of similar collections that contain this fauna in the western part of the basin indicate that the fauna is nondiagnostic. On the basis of a collection of plants from the Bear Formation that contained more Paleocene species than Cretaceous, Brown $(1962$, p. 7 ) assigned the formation to the Tertiary and placed the Cretaceous-Paleocene boundary at the contact of the Bear and Hell Creek Formations.

Simpson (1937, p. 21) divided the Lebo Andesitic Member of Stone and Calvert (1910) into two locally mappable units-the Lebo No. 1 (lower) and the Lebo No. 2 (upper). Simpson (1937, p. 25) proposed the name "Melville" for the formation overlying the Lebo No. 2 unit and suggested that future work might establish correlation with the Tongue River and perhaps Sentinel Butte Members of the Fort Union formation of eastern Montana. Stow (1946), as a part of his regional lithologic studies of Upper Cretaceous and Paleocene basin-fill sediments in the southeastern part of the Crazy Mountains basin, mapped the Tullock Formation from south-central Montana west to include Simpson's Bear Formation. He (1946, p. 678) also traced Simpson's Melville Formation southeast to Heart Mountain, Wyo., and considered the Melville to be equivalent to the Tongue River Formation. McMannis (1955, p. 1407) also recognized the Fort Union Formation along the western side of the basin including subdivisions corresponding to the ones recognized in the Livingston area.

Brown (1962, p. 17) collected fossil plants on Brackett Creek in sec. 9, T. 1 N., R. 7 E., southwest of Wilsall, Mont., which were the same species found in the Lebo and Simpson's Bear Formation on the east side of the Crazy Mountains. Although these collections were not strictly diagnostic, Brown assigned an early Paleocene age to about 1,500 feet of the upper part of Weed's Livingston Formation. He also commented that the strata at this locality are not clearly separable from the underlying Cretaceous beds by recognizable lithologic differences and well distributed unequivocal fossils. Dorf (in McMannis, 1955, p. 1409) assigned a probable Paleocene age to a flora from beds near Wilsall, Mont., which McMannis correlated with the middle sandstone and mudstone member near the Bridger Range.

Fine-grained clastic sedimentary rocks from the Fort Union (measured section 20) were sampled and examined for spores and pollen. On the basis of fauna from these samples (plant microfossils listed in table 4), the Cretaceous-Tertiary boundary is tentatively placed in the lower part of the Fort Union Formation, at the boundary between the lower and middle members. According to R. H. Tschudy (written commun., 1962), the lowest fossiliferous sample (D4105), 750 feet above the base, contains a Cretaceous assemblage similar to that obtained from the Hell Creek Formation. R. H. Tschudy (written commun., 1962) examined a sample (D1783) from 1,625 feet above the base and a sample (D1784) from 2,050 feet above the base and did not find Cretaceous fossils such as Tricolpites interangulus, Schizosporus complexus, or Aquilapollenites spp. The few species listed in table 4 (under D1783 and D1784) are characteristic of the early Tertiary or transgress the Cretaceous-Tertiary boundary.

The hystrichospheres and dinoflagellates in the uppermost Cretaceous palynomorph assemblage (sample D4105) indicate brackish-water deposition and the Ghoshispora probably grew in fresh-water lakes or ponds. As a whole, the palynomorph assemblage suggests that this sample was deposited in a deltaic environment. 
On Willow Creek, in the NW1/4 sec. 4, T. 1 S., R. 9 E., 9 miles north of Livingston, the writer collected a jaw and three teeth of a condylarth in Fort Union strata approximately 3,100 feet above the base (in Brown, 1962 , p. 8, 17; Roberts, 1965 , p. B60). This specimen was the first Paleocene mammal found west of the Crazy Mountains; it was identified by C.L. Gazin (written commun., 1958) as Tetraclaeonodon cf. T. symbolicus Gidley of middle Paleocene age, which has been described from the Lebo Member of the Fort Union. From beds at this locality, the writer also collected fresh-water mollusks identified by $\mathrm{D}$. W. Taylor (written commun., 1962) as Unionidae indet., Lioplacodes? sp., and Viviparus meeki Wenz. These mollusks do not provide a precise age determination, but are in accord with the middle Paleocene age assignment of C. L. Gazin.

\section{HEAVY-MINERAL SUITES IN THE FORT UNION FORMATION AND LIVINGSTON GROUP}

Examination of heavy-mineral suites from Upper Cretaceous and lower Tertiary rocks has contributed to a better understanding of the regional stratigraphic relations. Stow $(1938 ; 1946)$ first demonstrated a chronologic relationship between sedimentation and orogeny in the Crazy Mountains basin by heavy minerals. $\mathrm{He}$ identified characteristic mineral assemblages from known Upper Cretaceous and lower Tertiary formations in the northern part of the Bighorn Basin of Wyoming and, on the basis of relative frequency of significant minerals, extended correlations into the eastern part of the Crazy Mountains basin of Montana. In the western part of the Crazy Mountains basin, near Livingston, stratigraphic equivalents were similarly studied during the present investigation and the tabulation of data is shown in table 6. Stow (1938, p. 749) found that garnet, hornblende, kyanite, staurolite, tourmaline, and zircon were valuable for stratigraphic correlation or for ascertaining the source of the sedimentary rocks. In the Livingston area, anatase, diopsidic augite, garnet, rutile, tourmaline, and sillimanite have proved to be valuable minerals for these purposes. Diopsidic augite is limited to and common throughout the Livingston Group and Fort Union Formation and indicates a source from the Elkhorn Mountains Volcanics. Anatase is present in signifioant amounts only in the Cokedale Formation. Tourmaline and sillimanite are virtually restricted to the Cokedale and Miner Creek Formations. Zircon is present in all parts of the Livingston and Fort Union; however, its content is generally doubled in the Cokedale and Miner Creek Formations over its content in other parts of the sequence. The copper mineral, whitneyite, is present in significant amounts in the Cokedale and Miner Creek Formations, but also occurs in the underlying Eagle Sandstone. Garnet and rutile are common constituents in the Fort Union Formation, whereas they are uncommon in the Livingston Group. The nonopaque heavy minerals, except diopsidic augite, indicate a Precambrian source; however, Precambrian lithic fragments of pebble size or larger did not become common until the basal member of the Fort Union was deposited.

\section{EOCENE SERIES}

Volcanic and sedimentary units of Eocene age cap ridges in the northern part of the Gallatin Range. The sedimentary units consist chiefly of conglomerate and sandstone derived from lower Eocene volcanic rocks, Mesozoic and Paleozoic sedimentary rocks, and Precambrian metamorphic rocks. The volcanic units are dominantly flows and flow breccias. The source area for the sedimentary units was the uplifted parts of the Beartooth Range ito the southeast and the Gallatin Range to the south. Volcanic vents in the Gallatin Range and perhaps vents in the Beartooth Range contributed andesitic rock to the sedimentary units. The volcanic extrusive units were from vents in the Gallatin Range to the south and the Emigrant Peak area in the Beartooth Range to the southeast. Thickness of the Eocene Series varies due to the amount of relief at the base of the sequence; the units thin nirthward; some units extend farther north than others; and the sequence is truncated northward by post-Eocene erosion.

\section{CRANDALL (?) CONGLOMERATE}

At the base of the Eocene sequence at Chimney Rock, 15 miles southwest of Livingston in T. 3 S., R. 8 E., are two conglomerate units. The lower conglomerate is probably the Crandall Conglomerate of Pierce (1957) in northwestern Wyoming, on the basis of its stratigraphic position, age assignment of the overlying unit, and lithologic similarities. The Crandall Conglomerate was tentatively assigned to the lower Wasatchian of early Eocene age by Pierce (1957, p. 613). Brown (1961, p. 1175) extended use of the name Crandall(?) Conglomerate west into north-central Yellowstone Park, and Rubel (1964, p. 42) described a similar conglomerate at Monument Peak north of Yellowstone Park.

The Crandall(?) Conglomerate at Chimney Rock is 160 feet thick and is a cliff-forming coarse conglomerate (fig. 23). The formation is composed dominantly of boulders and contains lesser amounts of cobbles and pebbles. Some boulders are as much as 5 feet in diameter; however, most are 1 to 2 feet in diameter. The 


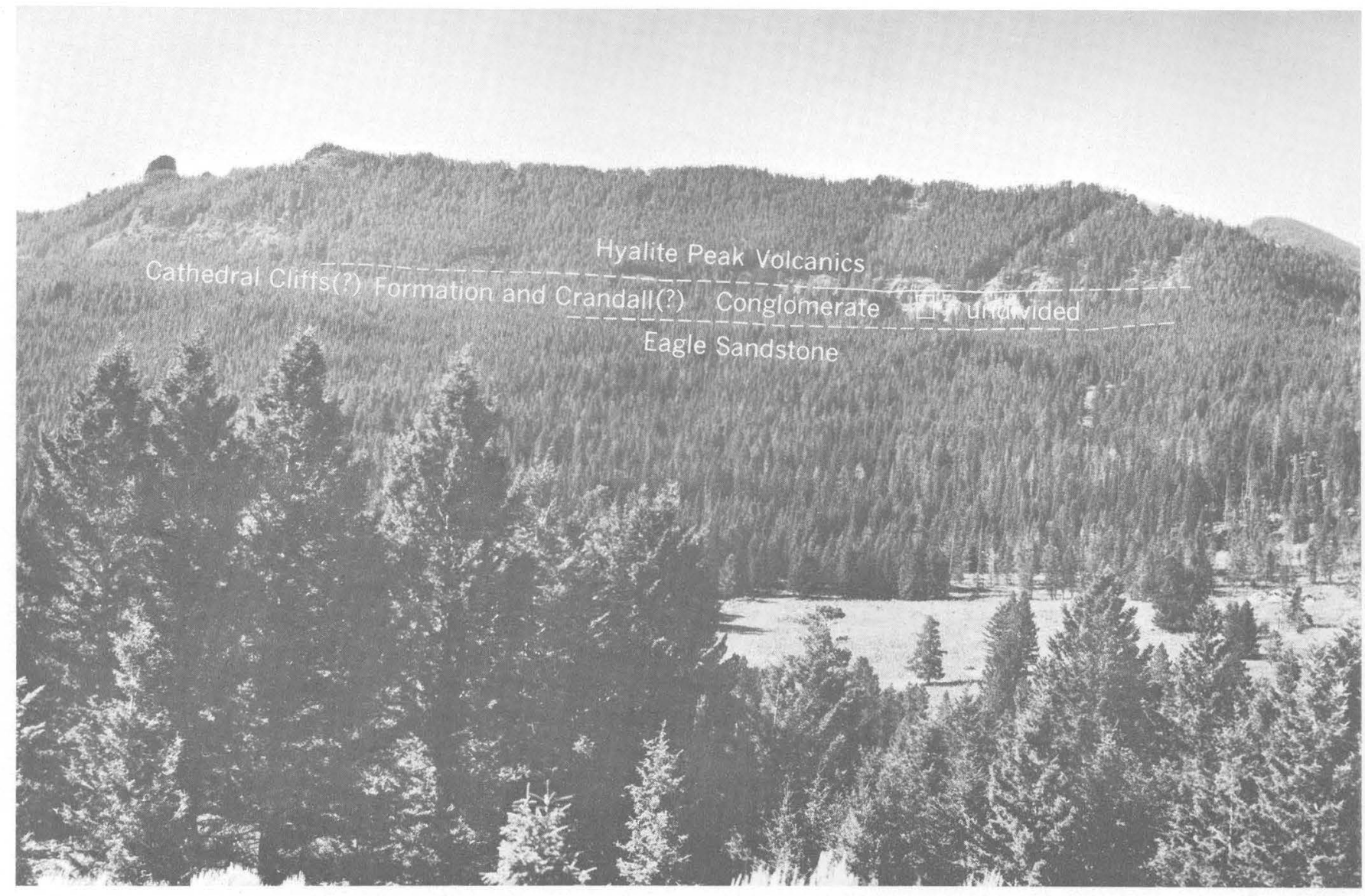

Frgure 23.- Sedimentary and volcanic rocks of Wasatchian and Bridgerian ages overlying the Eagle Sandstone of Late Cretaceous age at Maxey Ridge at the northern end of the Gallatin Range. Outlined area enlarged in figure 24 . Chimney Rock, prominent landmark in the area, is on the skyline on the upper left. View toward west.

clasts are subangular to well rounded but are commonly subrounded as shown in figure 24. Clasts are dominantly dacitic volcanic rock but include lesser amounts of Precambrian igneous and metamorphic rock and Paleozoic and Mesozoic sedimentary rock. The matrix is poorly sorted sand derived from similar rocks.

Stratification in the Crandall(?) Conglomerate is poor or absent. Sandstione lenses in the conglomerate are generally the only indication of bedding. Scour-and-fill structures are common.

Elsewhere in the Crazy Mountains basin, conglomerate of possible Eocene age occurs only in one very small area near the junction of the Crazy Mountains basin and Bighorn Basin. This conglomerate rests unconformably on tilted and eroded beds of the Fort Union Formation and is lithologically similar to the Crandall Conglomerate. Calvert (1917, p. 203) named this unit the Linley Conglomerate. There are no reported occurrences of rocks equivalent to the Crandall, north of the Canyon Mountain anticline in the western part of the Crazy Mountains basin.

\section{CATHEDRAL CLIFFS(?) FORMATION}

The Crandall(?) Conglomerate is overlain by 60 to 80 feet of loosely consolidated slope-forming conglomerate. Its stratigraphic position and petrologic composition suggest that this upper conglomerate is a facies of the lower part of the "early acid breccia" of Hague (Hague and others, 1899) in the Absaroka Range, the Reese Formation of Calvert (1912b, p. 56) in the southern part of the Gallatin Range, or the Cathedral Cliffs Formation of Pierce (1963) in the Clarks Fork area of northwestern Wyoming. The unit consists of boulders (largest observed was 8 feet in diameter), cobbles, pebbles, and sand. The heterogeneous mixture indicates very rapid deposition. The Cathedral Cliffs(?) Formation is composed entirely of volcanic rock fragments, generally of andesitic composition, and may be a lateral sedimentary facies of the lower part of the Golmeyer Creek Volcanics (R. A. Chadwick, written commun., 1969) or the Golmeyer Creek's equivalents in the Beartooth and Absaroka Ranges (H. W. Smedes, oral commun., 1968). Locally 


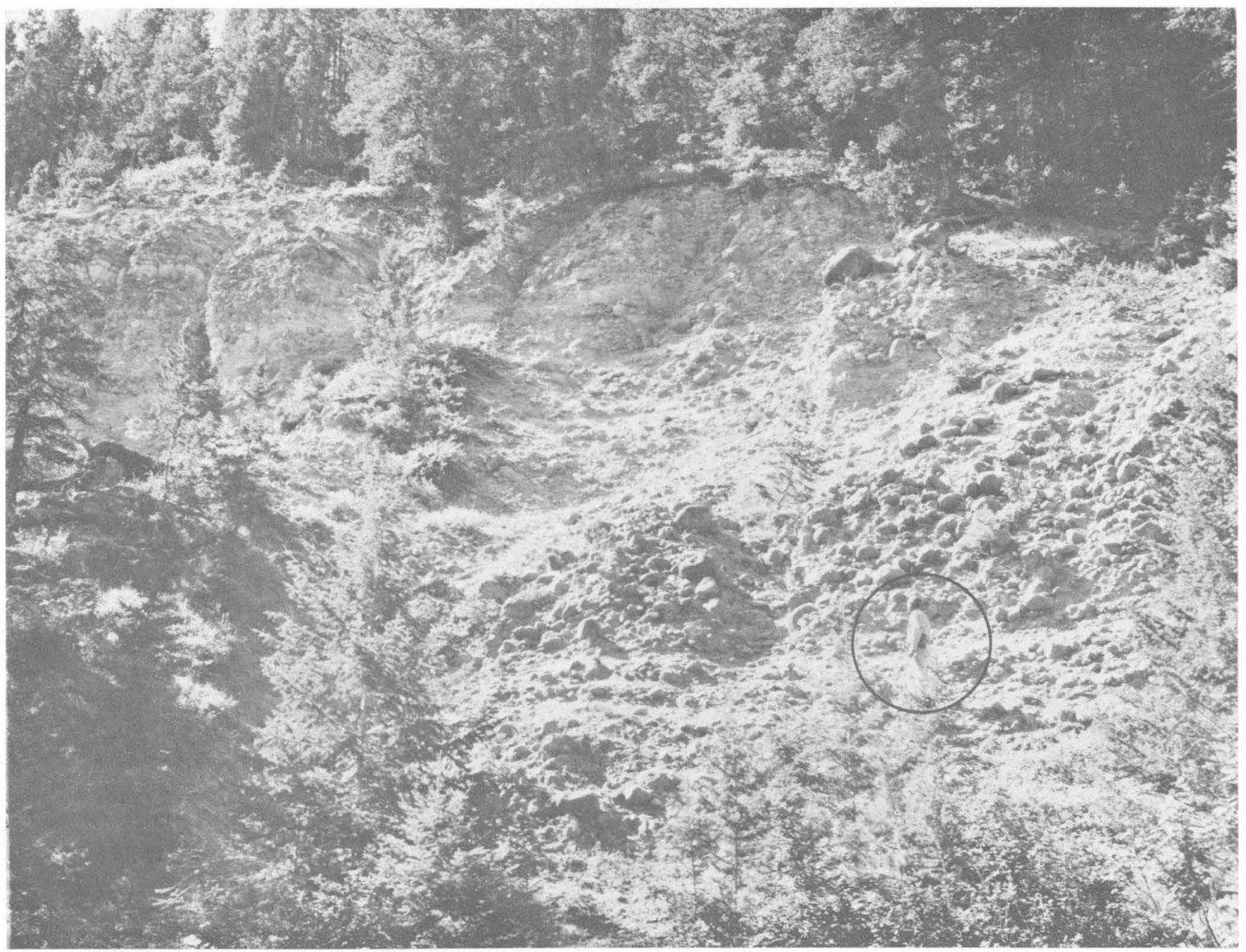

Figure 24.-Crandall(?) Conglomerate exposed on north side of Maxey Ridge in N1/2 sec. 31, T. 3 S., R. 8 E. Conglomerate composed dominantly of dacitic volcanic rock but contains lesser amounts of Precambrian igneous and metamorphic rocks and Paleozoic and Mesozoic sedimentary rocks. Note circled man for scale.

at the base of the Cathedral Cliffs( ?) Formation in the Garnet Mountain area is a carbonaceous siltstone (McMannis and Chadwick, 1964, p. 18) that contains plant spores and pollen which were identified by R. H. Tschudy (written commun., 1962) as being of late early Eocene or Wasatchian provincial age of Wood and others (1941).

\section{GOLMEYER CREEK VOLCANICS}

A sequence of several thousand feet of andesitic flows, flow breccias, mudflows, and lahars in the central part of the Gallatin Range was named the Golmeyer Creek Volcanics by Chadwick (1969), and that name is herein adopted. This volcanic unit overlies the Cathedral Cliffs (?) Formation about 10 miles south of the Livingston area in the central part of the Fridley Peak quadrangle. This forn tion is not present at Maxey Ridge in the north end of the Gallatin Range. The Golmeyer Creek Volcanics, together with the underlying Cathedral Cliffs (?) Formation, form the "early acid breccia" of Hague (Hague and others, 1899) for the northern part of the Gallatin Range.

\section{HYALITE PEAK VOLCANICS}

The youngest volcanic unit in the northern part of the Gallatin Range is a sequence of andesitic flows and flow breccias named the Hyalite Peak Voleanics by Chadwick (1969), and that name is herein adopted. This volcanic unit unconformably overlies the Cathedral Cliffs (?) Formation in the northern part of the Gallatin Range (fig. 25). At Maxey Ridge this formation is approximately 1,500 feet thick and thickens southward. This andesitic unit is probably equivalent to the "early basic breccia" of Hague (Hague and 


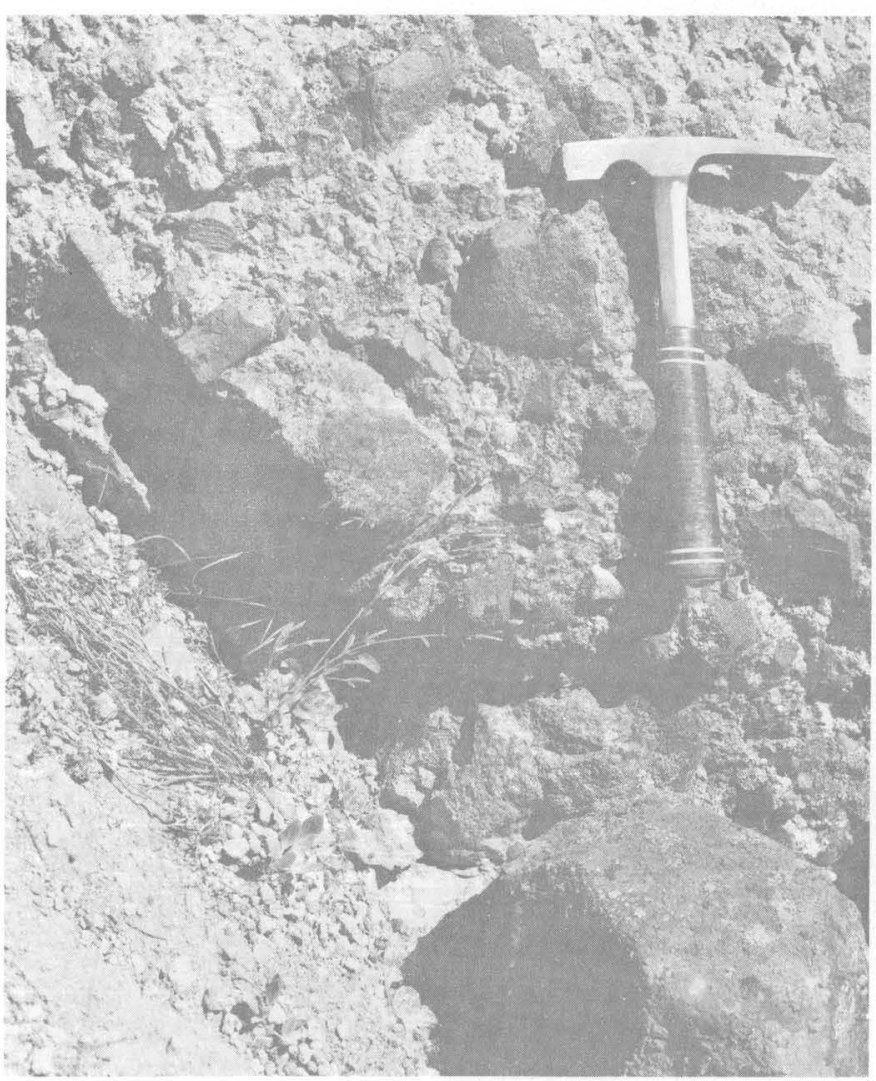

Figure 25.-Volcanic agglomerate or lahar in the Hyalite Peak Volcanics that overlie the Cathedral Cliffs(?) Formation at Maxey Ridge in the $\mathrm{N} 1 / 2$ sec. 31 , T. 3 S., R. 8 E.

others, 1899), which has a Bridgerian age in the northern Absaroka Range and in the Yellowstone National Park area, Wyoming.

\section{SELECTED STRATIGRAPHIC SECTIONS}

Sedimentary sections measured, described, and sampled for stratigraphic and paleontologic control in southwestern Montana and north-central Wyoming as part of the investigation of the Livingston coal field are presented in the following pages. Twenty stratigraphic sections were selected as the most useful to provide a framework for stratigraphic and paleontologic studies of Cretaceous and Paleocene formations of southwestern Montana. More than one measured section is given for certain formations in which significant lateral variations in lithology are meaningful for a better understanding of its stratigraphy. These variations in lithology are best illustrated in selected sections that are normal to what was the strand line during deposition of that formation. Stratigraphic relations are summarized graphically in figures 2 and 22, and microfossil data are presented in tabulated form in tables 2 to 4 . Four of the selected sections are type sections; one is redefined as a typical section; seven are designated as reference sections; and eight provide additional stratigraphic and paleontologic control.

The sections are arranged by formation in order of decreasing geologic age. Beds containing fossils are designated by their assigned fossil-collection number, for example, USGS Paleobotany locality D3512-T or USGS Mesozoic locality D581.

In the bed descriptions, rock names consist of a noun denoting the dominant constituent followed by adjectives denoting other constituents present. Terms describing grain size, hardness, thickness of bedding, color, and additional information-such as the presence of an unusual or distinctive mineral-are given.

\section{METHODS OF STUDY AND DEFINITIONS OF TERMS}

Stratigraphic sections were selected for completeness of the sequence and minimal structural complexity. The sections were measured by planetable and alidade and by tape and Brunton traverse. Representative samples were collected, generally from the middle of each lithologic unit. Descriptions of the stratigraphic units include megascopic and petrographic determinations of physical properties. Color designations were based on the "Rock-Color Chart" of the National Research Council (Goddard and others, 1948). The terminology applied to fragmental volcanic rocks is mainly that of Wentworth and Williams (1932, p. 45-53) and Williams, Turner, and Gilbert (1954, p. 149-150).

In referring to the bedding of the rocks, the following standard was used: massive means greater than 4 feet in thickness; thick bedded means 2 to 4 feet; medium bedded, 6 inches to 2 feet; thin bedded, 2 to 6 inches; and very thin bedded, $1 / 2$ to 2 inches. Platy refers to beds $1 / 16$ to $1 / 2$ inch thick, and laminae are less than $1 / 16$ inch.

Grain-size distributions for detrital rocks were determined by conventional sieve and pipette analyses. The following grain sizes are used : granule means more than $2 \mathrm{~mm}$; very coarse, 1.00 to $2.00 \mathrm{~mm}$; coarse, 0.50 to $1.00 \mathrm{~mm}$; medium, 0.25 to $0.50 \mathrm{~mm}$; fine, 0.125 to $0.25 \mathrm{~mm}$; and very fine 0.0625 to $0.125 \mathrm{~mm}$. Sorting refers to the distribution of individual grain-size classes. The following terms are used: well sorted means 90 percent of grains concentrated in one or two size classes; medium sorted or fairly well sorted, 90 percent of grains distributed in three or four size classes; and poorly sorted, 90 percent of grains scattered in five or more size classes. Claystone designates a rock composed essentially of clay-size particles. Mudstone designates nonfissile rocks that are predominantly of clay- 
size particles but contain lesser amounts of silt and very fine sand. Shale is regarded as a structural term for a fissile mudstone.

In describing the relative abundance of fossils, and occasionally of rock types or other material, the following standard was used : very abundant means that the fossils (or other constituents) compose most of the rock or unit; abundant means that they make up a considerable part; plentiful, that they can be found with ease; common, that they can be found in most hand specimens of rocks; rare, that they are generally difficult to find; and very rare, that considerable searching is necessary.

\section{KOOTENAI FORMATION}

Three stratigraphic sections of the Kootenai Formation are considered typical of the formation in the area west of Livingston. These are measured section 1 on the west flank of Chestnut Mountain anticline, measured section 2 on the south flank of the Canyon Mountain anticline, and measured section 3 on the north flank of the Canyon Mountain anticline. The lateral variation in lithology but uniform total thickness of the formation is well illustrated. Average grain size of the sandstone decreases from west to.east. The well-exposed and accessible section on the west flank of the Chestnut Mountain anticline is here designated a reference section.

\section{SECTION 1}

Reference section of the Kootenai Formation, measured in the NE1/4 sec. 25, T. 2 S., R. 6 E., Gallatin County, Mont.

[Measured by A. E. Roberts, 1956. See fig. 5]

Lower Cretaceous-Thermopolis Shale.

Lower Cretaceous-Kootenai Formation:

33. Claystone, olive-gray ( $5 Y 4 / 1)$, calcareous; weathers to light olive gray $(5 Y 6 / 1) \ldots$

32. Sandstone, thin-bedded, greenish-gray ( $5 G Y$ $6 / 1$ ), very fine grained, silty, calcareous; weathers to dark yellowish orange $(10 Y R$ 6/6) . . . . . . .

31. Limestone, massive, dense, light-olive-gray (5Y 5/2), very fine grained, fossiliferous; probably of fresh-water origin; weathers to pale yellowish brown $(10 Y R 6 / 2)$; contains abundant ostracodes...................

30. Siltstone, dusky-yellowish-brown (10YR 6/2), sandy, calcareous; contains stringers of carbonaceous material; weathers to moderate vellowish brown $(10 Y R 4 / 2) \ldots \ldots$. . . .

29. Siltstone, dusky-yellowish-brown (10YR 2/2), sandy, calcareous; weathers to moderate yellowish brown $(10 Y R$ 5/4)

28. Claystone, dark-olive-gray (5Y 3/1), calcareous; weathers to pale yellowish brown (10YR $6 / 2)$
SECTION 1 -Continued

Reference section of the Kootenai Formation, measured in the NE1/4 sec. 25, T. 2 S., R. 6 E., Gallatin County, Mint.-Con.

Lower Cretaceous-Kootenai Formation-Continued $F t \quad$ In

27. Limestone, irregularly bedded, thick-bedded, dense, silty, light-olive-gray ( $5 Y$ 6/1), fineto medium-grained, fossiliferous; probably of fresh-water origin; contains ostracodes and gastropods; weathers to yellowish gray ( $5 Y$

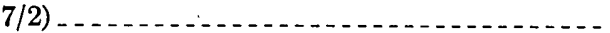

26. Mudstone, olive-gray (5Y 4/1); weathers to light olive gray $(5 Y 6 / 1) \ldots$

25. Siltstone, grayish-green ( $10 G Y 5 / 2)$, noncalcareous; contains small (2-4 in. thick) irregularly shaped concretions near base; weathers to grayish yellow green $(5 G Y 7 / 2)$ - -

24. Siltstone, dark-reddish-brown (10R 3/4), clayey; weathers to grayish red $(10 R 5 / 2)$. -

23. Sandstone, massive, grayish-green ( $10 G 5 / 2)$, medium-grained, poorly sorted, moderately indurated; grains composed of volcanic rock; weathers to greenish gray $(5 G Y 6 / 1) \ldots \ldots$.

22. Sandstone, medium-bedded, greenish-gray ( $5 G Y 6 / 1)$, very fine grained, slightly indurated; weathers to light olive gray

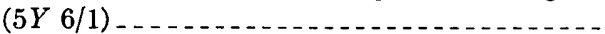

21. Siltstone, thin-bedded, grayish-red ( $10 R 4 / 2)$,

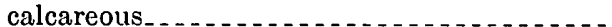

20. Limestone, medium-bedded, grayish-red (10R $4 / 2$ ), argillaceous; weathers to pale reddish brown $(10 R 5 / 4)$. Three inches of grayishred $(10 R 4 / 2)$ calcareous siltstone $3 \mathrm{ft}$ above the base of unit. This limestone unit is probably equivalent to the fossiliferous limestone that contains fresh-water gastropods and ostracodes and crops out on the north shore of Mystic Lake in sec. 25, T. 3 S., R. 6 E. . . . . . . . . . . . . . . . .

19. Siltstone, thin-bedded, grayish-red (10R 4/2), calcareous . . . . . . . . . . . . . . .

18. Limestone, thin-bedded, grayish-red ( $10 R 4 / 2)$,

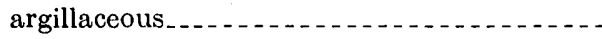

17. Siltstone, grayish-red $(10 R 4 / 2)$, slightly calcareous; weathers to pale reddish brown (10R 5/4)

24

10

46

147

50

10

16. Sandstone, crossbedded, mottled grayish-red $(10 R 4 / 2)$ and grayish-green $(5 G 5 / 2)$, very fine grained, silty, slightly calcareous, moderately indurated; weathers to pale reddish brown $(10 R 5 / 4)$ and grayish yellow green (5GY $7 / 2) \ldots$. .

15. Siltstone, grayish-red $(10 R 4 / 2)$, slightly calcareous. . . . . . . . . . . . . . . . . . . .

14. Sandstone, crossbedded, mottled grayish-red $(10 R 4 / 2)$ and grayish-green $(5 G 5 / 2)$, very fine grained, silty; weathers to pale reddish brown $(10 R 5 / 4)$ and grayish yellow green $(5 G Y 7 / 2)$

13. Sandstone, very thin bedded and crossbedded, grayish-red $(10 R 4 / 2)$, very fine grained, slightly calcareous, indurated; weathers to pale reddish brown $(10 R 5 / 4) \ldots \ldots \ldots \ldots$ 


\section{SECTION 1 -Continued}

Reference section of the Kootenai Formation measured in the $N E^{1 / 4}$ sec. 25, T. 2 S., R. 6 E., Gallatin County, Mont.-Continued

Lower Cretaceous-Kootenai Formation-Continued ${ }^{F t} \quad$ In.

12. Siltstone, thin-bedded to massive, multicolored (red, brown, purple, and green); contains some small channel-fill deposits of fine-grained sandstone and nodular concretions.

11. Sandstone, thin-bedded to massive, mottled grayish-red $(10 R \quad 4 / 2)$ and light brownishgray $(5 Y R 6 / 1)$, very fine grained, silty, poorly sorted, calcareous, indurated; weathers to mottled yellowish gray $(5 Y 8 / 1)$ and pale red $(10 R 6 / 2)$

10. Siltstone, thin-bedded and crossbedded, multicolored (red and green), sandy; unit varies in thickness; lower $4 \mathrm{ft}$ is a channel-fill deposit; contains small (6 in. in diameter or less) concretions and lenticular beds $(1 \mathrm{ft}$ thick or less) of calcareous sandstone......

9. Limestone, medium- to thick-bedded, grayishred $(10 R 4 / 2)$, argillaceous; some dendritic manganese staining; weathers to pale red $(10 R 6 / 2)$

8. Siltstone, thin-bedded and crossbedded, multicolored (red, purple, and green), sandy, calcareous; contains lenticular calcareous sandstone beds ( $1 \mathrm{ft}$ thick or less) and calcareous sandstone concretions . . . . . . . . . . . . .

7. Claystone, multicolored (red, purple, yellow, and green), silty ............................

6. Sandstone, thin-bedded to massive grayish-red $(10 R 4 / 2)$, very fine grained, silty, indurated, calcareous; mottled locally grayish red $(10 R$ 4/2) and greenish gray (5GY 6/1) ..........

5. Mudstone, multicolored (purple and green),

4. Silty, soft durated, slightly calcareous; locally some greenish-gray ( $5 G Y$ 6/1) mottling; weathers to grayish orange pink $(5 Y R 7 / 2)$

3. Mudstone, massive, multicolored (purple, red, and green); upper $9 \mathrm{ft}$ indurated, lower $5 \mathrm{ft}$ thin to medium bedded containing lenticular beds of calcareous very fine grained sandstone; unit contains many calcareous very fine grained sandstone concretions as large as 2-3 $\mathrm{ft}$ in diameter.

2. Sandstone, massive, medium-dark-gray (N4), very fine grained, silty, indurated; weathers to yellowish gray $(5 Y 7 / 2)$; lower contact gradational with underlying conglomerate..

Pryor Conglomerate Member:

1. Conglomerate, poorly bedded and crossbedded to massive; much of the unit is conglomeratic sandstone; pebbles are dominantly chert; sand grains of matrix composed dominantly of quartz and chert; lower half of unit contains several thin-bedded siltstones ( $1 \mathrm{ft}$ or less in

thickness) Total thickness of Kootenai Formation _. _ $255 \quad 6$

Upper Jurassic-Morrison Formation.

\section{SECTION 2}

Kootenai Formation measured in the $N W 1 / 4$ sec. 22, T. 3 S., R. 9 E., Park County, Mont.

[Measured by A. E. Roberts and C. A. Sandberg, 1959]

Lower Cretaceous-Thermopolis Shale.

Lower Cretaceous-Kootenai Formation:

Ft In.

13. Siltstone and mudstone, massive, grayish-red $(10 R 4 / 2)$, calcareous in part; also some interbedded pale-yellowish-brown (10YR 6/2) claystone; approximately $20 \mathrm{ft}$ above base is a nodular chert zone and about $5 \mathrm{ft}$ below this zone the color changes to grayish red purple (5RP 4/2)

12. Tuff, thin- to thick-bedded, pale-yellowishbrown $(10 Y R 6 / 2)$, silty; weathers to moderate yellowish brown (10YR 5/4); slight tendency to form ridges; considerable manganese staining on joint and fracture surfaces....................................

11. Claystone, massive, grayish-red $(5 R 4 / 2)$, very calcareous; slight tendency to form ridges. - -

10. Mudstone, massive, light-brownish-gray ( $5 Y R$ $6 / 1)$; contains streaks of grayish red $(5 R$ $6 / 2)$; poorly exposed; upper few feet is transitional with overlying unit

9. Claystone, massive, grayish-red $\left(\begin{array}{ll}5 R & 4 / 2\end{array}\right)$; poorly exposed; forms saddles in slopes......
240

$9 \quad 10$

17

10 26

18

10

8

$37 \quad 0$
8. Limestone, irregularly bedded, light-olive-gray (5Y 6/1) and mottled yellowish-gray (5Y 8/1) and light-olive-gray; in part silty and sandy, containing rounded grains of quartz and chert; some thin discontinuous beds of silt and some small scour-and-fill channels that are less than $1 \mathrm{ft}$ thick and contain small chert pebbles. .............................

7. Mudstone, massive, grayish-red $(5 R \quad 4 / 2)$; poorly exposed.............................

6. Siltstone, thin- to medium-bedded, pale-yellowish-brown $(10 Y R 6 / 2)$, very calcareous; weathers to grayish orange $(10 Y R 7 / 4)$; some manganese staining within the rock .........

5. Sandstone, thin- to thick-bedded, pale-yellowishbrown (10YR 7/2), fine- to medium-grained, very calcareous; weathers to pale yellowish brown (10YR 6/2); contains some hematite nodules; contains some ferromagnesian grains that are generally altered to limonite. . .....

4. Sandstone, massive and crossbedded, yellowishgray ( $5 Y 8 / 1)$, poorly sorted; quartz and chert grains cemented by calcite; weathers to grayish orange $(10 Y R \quad 7 / 4)$; scour-and-fill channel $4.5 \mathrm{ft}$ above base: channel is $3.5 \mathrm{ft}$ thick, $20 \mathrm{ft}$ wide, and filled with quartz granules and chert pebbles; lower $3 \mathrm{ft}$ contains many pebbles.

80

3. Covered, probably light-yellowish-gray siltstone...

2. Sandstone, medium- to thick-bedded, pinkishgray (5YR 8/1), medium-grained; quartz grains cemented by calcite; unit slightly indurated but poorly exposed............. 
SECTION 2-Continued

Kootenai Formation measured in the NW14 sec. 2Q, T. 3 S., R. 9 E., Park County, Mont.-Continued

Lower Cretaceous-Kootenai Formation-Continued Pryor Conglomerate Member:

1. Conglomerate, massive and crossbedded, yellowish-gray ( $5 Y 8 / 1)$; quartz and chert grains, granules, and pebbles cemented by calcite; much of unit is conglomeratic sandstone and contains many scour-and-fill channel deposits; ridge former

Upper Jurassic-Morrison Formation.

\section{SECTION 3}

Composite section of the Kootenai Formation, measured on the north side of Canyon Mountain in sec. 35, T. 2 S., R. 9 E., and adjusted with section of the Deerfield Oil Corp. Strong 1 well in sec. 11, T. Q S., R. 9 E., Park County, Mont.

[Measured by A. E. Roberts and J. S. Hollingsworth, 1955.]

Lower Cretaceous-Thermopolis Shale.

Lower Cretaceous-Kootenai Formation:

18. Mudstone, thick-bedded, grayish-red $(10 R$ $\left.4^{\prime} 2\right)$, soft................................

17. Siltstone, thin-bedded, light-gray; contains interbedded grayish-red shale.............

16. Mudstone, thin-bedded, micaceous, gray contains interbedded medium-gray siltstone.

15. Mudstone, thin-bedded to massive, silty, grayish-red to purple; contains thin interbedded shale, siltstone, and limestone..........

14. Limestone, medium-bedded, silty, mottled gray and grayish-red, fintly crystalline.........

13. Siltstone, thin-bedded, micaceous, grayish-red; contains thin interbedded grayish-red shale.

12. Mudstone, massive, silty, mottled light-gray and purple (5RP 4/2) and grayish-red......

11. Limestone, medium-bedded, light-gray, finely crystalline...............................

10. Mudstone, thin-bedded to massive, silty, micaceous, grayish-red and purple; contains thin interbedded siltstone and shale.......

9. Claystone, thin-bedded, light-gray to green (altered tuff bed?).......................

8. Mudstone, thin-bedded to massive, mottled gray and reddish-gray ..................

7. Mudstone, thin- to thick-bedded, silty, pyritic, grayish-red; contains thin interbedded siltstone and purple shale ...................

6. Claystone, thick-bedded, grayish-red, calcareous; weathers to pale yellowish brown (10YR 6/2) ...........

5. Sandstone, medium-bedded, silty, pyritic, indurated yellowish-gray $(5 Y 7 / 2)$, fine- to very fine grained; angular grains..............

4. Mudstone, medium-bedded, sandy, calcareous, grayish-red; weathers to pale yellowish brown $(10 Y R 6 / 2)$
SECTION 3-Continued

Composite section of the Kootenai Formation, measured on the north side of Canyon Mountain in sec. 35, T. 2 S., R. 9 E., and adjusted with section of the Deerfield Oil Corp. Strong 1 well in sec. 11, T. 2 S., R. 9 E., Park County, Mont.-Continued

Lower Cretaceous-Kootenai Formation-Continued $\quad F t \quad$ In.

3. Sandstone, massive, crossbedded, pyritic, indurated, gravish-orange $(1 C Y R \quad 7,4)$, very fire to fine-grained; ferromagnesian minerals altered to limonite give the orange color; weathers to moderate yellowish brown (10YR $5 / 4)$; angular to subrounded grains; ridge former - . 2 -

2. Sandstone, irregularly bedded, yellowish-gray (5Y 7/2) very fine to fine-grained, very poorly sorted, silty; weathers to dark yellowish orange (10YR 6/6); contains sporadic sand grains as large as granule size...........

Pryor Conglomerate Member:

1. Conglomerate and sandstone, massive, crossbedded, calcitic, very poorly sorted; indurated Conglomerate composed mainly of subrounded chert pebbles. Sandstone composed dominantly of angular to subrounded quartz and quartzite grains. Unit has graded beddingcoarse at the base. Very prominent ridge former

Total thickness of Kootenai Formation _. _ 292 180 Upper Jurassic-Morrison Formation.

Two stratigraphic sections of the Thermopolis Shale are considered to be typical of the formation in the Gallatin County, Mont.

Lower Cretaceous-Mowry Shale.

Lower Cretaceous-Thermopolis Shale:
80 Upper sandstone member: Ft In

28. Sandstone, fine-grained, uncemented partly altered to a moderate-yellowishbrown (10YR 5/4) clay.............. 10 


\section{SECTION 4-Continued}

Reference section of the Thermopolis Shale, measured on the north side of Rocky Creek Canyon in the SW1/4 sec. 20, T. 2 S., R. 7 E., Gallatin County, Mont.-Continued

Lower Cretaceous-Thermopolis Shale-Continued Upper sandstone member-Continued

27. Sandstone, medium- to thick-bedded, very fine to fine-grained, well-sorted, calcareous, indurated, medium-gray (N5); weathers to yellowish gray $(5 Y 7 / 2)$. Contains heavy-mineral suite that excellently marks individual layers. These layers are commonly crossbedded in beds as much as 6 in. thick. Scme large plant fragments were found on bedding surfaces, and a few bedding surfaces are ripple marked. A few of the sandstone beds contain claystone pebbles. In weathered outcrop, heavy minerals alter to limonite and hematite ............

26. Mudstone, massive, carbonaceous, oliveblack (5Y 2/1); weathers to light gray (N7); USGS Paleobotany loc. D3512$\mathrm{U}, 7 \mathrm{ft}$ above base of unit.........

25. Sandstone, medium- to thick-bedded, very fine to fine-grained, indurated, medium-light-gray (N6); weathers to yellowish gray $(5 Y 7 / 2)$. Bedding surfaces are covered with carbonaceous trash. Some bedding surfaces are rippled marked, and many have marine worm(?) trails and groove and small flute casts. Contains heavy-mineral suite. Between the sandstone beds are thin layers of carbonaceous claystone or siltstone. USGS Paleobotany loc. D3512-T, $9.5 \mathrm{ft}$ above base of unit.......

Total thickness of upper sandstone member.....................

Middle shale member:

24. Mudstone and interbedded siltstone and sandstone. The volume of sandstone in this unit gradually increases upward; the unit is a transition zone between the underlyirig shale unit and the overlying sandstone unit. The upper $5 \mathrm{ft}$ is dominantly sandstone. The mudstone is massive, olive black ( $5 Y 2 / 1)$, and weathers to medium light gray $(N 6)$. The sandstone is thin bedded, very fine grained, silty, medium gray (N5), and weathers to light olive gray (5Y 5/2). Most beds contain plant fragments. Bedding surfaces are commonly ripple marked.

23. Shale, massive, carbonaceous, tuffaceous, olive-black (5Y 2/1); weathers to medium light gray (N6). Lower $10 \mathrm{ft}$ contains poorly sorted sand grains. Bentonite beds were noted as follows:

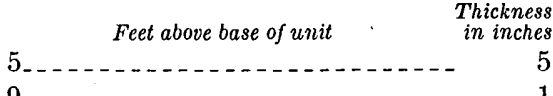

9
SECTION 4-Continued

Reference section of the Thermopolis Shale, measured on the north side of Rocky Creek Canyon in the SW14 sec. 20, T. Q S., R. 7 E., Gallatin County, Mont.-Continued

Lower Cretaceous-Thermopolis Shale-Continued Middle shale member-Continued

Ft In.

$\begin{array}{rr}\text { Feet above base of unit } & \begin{array}{r}\text { Thickness } \\ \text { in inches }\end{array} \\ 15 & 4 \\ 34.5 & \\ 53.3 & 1 \\ 58.1 & \end{array}$

USGS Paleobotany loc. D3512-M is $5 \mathrm{ft}$ above base of unit; USGS Paleobotany loc. D3512-N, $31 \mathrm{ft}$ above base of unit; USGS Paleobotany loc. D3512-O, $48 \mathrm{ft}$ above base of unit; and USGS Paleobotany loc. D3512-P, $63 \mathrm{ft}$ above base of unit.

22. Sandstone, thin-bedded, very fine to medium-grained, poorly sorted, carbonaceous (?), tuffaceous, mediumdark-gray (N4); weathers to very light gray (N8) and has some limonitic alteration. Very small selenite crystals in areas of limonitic alteration. Also contains approximately 10 percent interbedded brownish-black (5YR 2/1) shale._................

21. Sandstone and interbedded shale (sandstone approximately 75 percent). Sandstone is thin bedded, very fine grained, silty, light gray (N7), and weathers to light olive gray $(5 Y 5 / 2)$. Basal $1 \mathrm{ft}$ is bentonitic. Shale is brownish black (5YR 2/1) and weathers to medium light gray $(N 6)$.

20. Shale, tuffaceous, brownish-black ( $5 Y R$ $2 / 1)$; weathers to medium light gray (N6); contains very small selenite crystals throughout; unit is partly altered

19. Sandstone, thin-bedded, very fine grained, silty, light-gray (N7); weathers to light olive gray (5Y 5/2); much limonitic weathering; some very small selenite crystals in small rosettes on bedding surfaces ..........................

18. Shale, dark-gray (N3); weathers to medium light gray (N6); contains very few (less than 5 percent) thin beds or lenses of very fine grained sandstone. USGS Paleobotany loc. D3512-F, $1 \mathrm{ft}$ above base of unit; USGS Paleobotany loc. D3512-G, $15 \mathrm{ft}$ above base of unit; USGS Paleobotany loc. D3512-H, $30 \mathrm{ft}$ above base of unit; USGS Paleobotany loc. D3512-I, $45 \mathrm{ft}$ above base of unit; USGS Paleobotany loc. D3512-J, $60 \mathrm{ft}$ above base of unit; USGS Paleobotany loc. D3512-K, $75 \mathrm{ft}$ above base of unit; and USGS Paleobotany loc. D3512-L, $90 \mathrm{ft}$ above base of unit 


\section{SECTION 4-Continued}

Reference section of the Thermopolis Shale, measured on the north side of Rocky Creek Canyon in the SW1/4 sec. 20, T. $2 S$., R. 7 E., Gallatin Couniy, Mont.-Continued

Lower Cretaceous-Thermopolis Shale-Continued Middle shale member-Continued

17. Sandstone and interbedded shale (sandstone approximately 70 percent). Sandstone is thin bedded, very fine to fine grained, silty, indurated, calcareous, medium gray $(N 5)$, and weathers to light gray $(N 7)$. Shale is carbonaceous, dark gray $(N 3)$, and weathers to medium light gray $(N 6)$

16. Shale and interbedded sandstone (shale approximately 60 percent). Shale is carbonaceous, dark gray (N3), and weathers to medium light gray $(N 6)$. Sandstone is thin bedded, very fine to fine grained and silty. Although lithologically similar to unit 15 , this unit is less indurated.

15. Sandstone and interbedded shale (sandstone is approximately 80 percent). Sandstone is thin bedded, very fine to fine grained, silty, indurated, calcareous, medium gray (N5), and weathers to light gray (N7). Most bedding surfaces are covered with worm (?) trails and groove and small flute casts. Contains plant fragments. Shale in very thin interbeds is carbonaceous, dark gray (N3), and weathers to medium light gray ..............................

14. Shale and interbedded sandstone (shale is approximately 80 percent). Shale is dark gray $(N 3)$ and weathers to medium light gray $(N 6)$. It is very carbonaceous, containing abundant plant fragments. Sandstone is thin bedded, very fine grained, calcareous, very light gray (N8), and weathers to yellowish gray $(5 Y 8 / 1)$ and moderate yellowish brown (10YR 5/4). Some bedding surfaces are covered with worm(?) trails and groove and small flute casts. USGS Paleobotany loc. D3512-D, $5 \mathrm{ft}$ above base of unit.....

13. Shale, dark-gray $(N 3)$; weathers to medium light gray (N6). Contains many calcareous lenses and a few nodules and septarian concretions that weather to grayish orange $(10 Y R 7 / 4)$ to yellowish gray $(5 Y \cdot / 2)$. This unit is less indurated than the ovorlying unit. The weathered surface of the outcrop has an overall yellowish-gray (5Y 7/2) appearance due to the presence of the many weathered calcareous chips, whereas the overlying unit is a uniform medium light gray (N6). USGS Paleobotany loc. D3512-A, $1 \mathrm{ft}$ above base of unit; USGS Paleobotany loc. D3512-B, $15 \mathrm{ft}$ above base of unit;

\section{SECTION 4-Continued}

Reference section of the Thermopolis Shale, measured on the north side of Rocky Creek Canyon in the SW 14 sec. 20, T. 2 S., R. 7 E., Gallatin County, Mont.-Continued

Lower Cretaceous-Thermopolis Shale-Continued Middle shale member-Continued and USGS Paleobotany. loc. D3512-C, 28 ft above base of unit.............. $29 \quad 4$

Total thickness of middle shale member....... $352 \quad 0$

Lower sandstone member:

12. Sandstone, thin- to medium-bedded, very fine grained, silty, light-brownish-gray (5YR 6/1); weathers to light gray (N7)..

11. Claystone, massive, olive-gray (5Y 4/1); weathers to yellowish gray ( $5 Y 8 / 1)$; contains some carbonaceous material ......

10. Sandstone, thin-bedded, very fine grained, silty, light-brownish-gray ( $5 Y R 6 / 1)$; weathers to light gray $(N 7)$ and has some limonitic staining; bedding surfaces are covered with marine worm(?) trails and groove casts and 'other sole marks of undetermined origin

9. Sandstone, thin- to medium-bedded, finegrained, well-sorted, well-indurated (almost a quartzite), very pale orange $(10 Y R 8 / 2)$; weathers to grayish orange $(10 Y R, 7 / 4)$; composed dominantly of clean quarty grains and contains a few laminae of heavy minerals.............

8. Sandstone, very thin bedded, very fine grained, silty, micaceous, quartzose, medium-gray $(N 5)$; weathers to yellowish gray $(5 Y 7 / 2) \ldots \ldots$

7. Sandstone, thin- to medium-bedded, finegrained, well-indurated (almost a quartzite), mottled light-brownish-gray ( $5 Y R$ $6 / 1)$ and brownish-gray (5YR 4/1); irregular base due to filling of mud cracks at the top of the underlying unit......

6. Claystone, thick-bedded, carbonaceous, brownish-gray (5YR 4/1); weathers to light olive gray $(5 Y, 6 / 1) \ldots \ldots . . . . .$.

5. Sandstone, massive, fine-grained, wellsorted, well-indurated (almost a quartzite), very pale orange $(10 Y R \quad 8 / 2)$; weathers to grayish orange $(10 Y R 7 / 4)$; composed dominantly of clean quartz grains and contains few heavy minerals.

4. Sandstone, thin- to medium-bedded, very fine grained, micaceous, quartzose, medium-light-gray $(N 6)$; weathers to light olive gray (5Y6/1) and bears considerable dark-hematitic staining; contains few scattered carbonaceous fragments.......

3. Sandstone, very thin bedded, very fine grained, silty, micaceous, quartzose, medium-gray (N5); weathers to yellowish gray $(5 Y 7 / 2) \ldots \ldots$ 


\section{SECTION 4-Continued}

Reference section of the Thermopolis Shale, measured on the north side of Rocky Creek Canyon in the SW1/4 sec. 20, T. 2 S., R. 7 E., Gallatin County, Mont.-Continued

Lower Cretaceous-Thermopolis Shale-Continued Lower sandstone member-Continued

2. Sandstone, thin- to medium-bedded, finegrained, well-sorted, well-indurated (almost a quartzite), very pale orange $(10 Y R 8 / 2)$; weathers to grayish orange (10YR 7/4); composed dominantly of clean quartz grains and contains few laminae of heavy minerals...........

1. Sandstone, thin-bedded, fine-grained, wellsorted, quartzose, indurated (but less than overlying unit), mottled light-gray (N7) and medium-light-gray (N6); weathers to mottled yellowish gray ( $5 Y$ $7 / 2$ ) and very light gray $(N 8)$; the lower

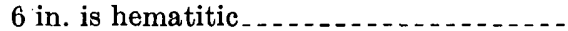

Total thickness of lower sandstone member

Total thickness of Thermopolis Shale_ $493 \quad 0$ Lower Cretaceous-Kootenai Formation.

\section{SECTION 5}

Composite section of the Thermopolis Shale, measured on the north side of Canyon Mountain in sec. 35, T. Q S., R. 9 E., and adjusted with section of the Deerfield Oil Corp. Strong 1 well in sec. 11, T. 2 S., R. 9 E., Park County, Mont.

[Measured by A. E. Roberts, 1961]

Lower Cretaceous-Mowry Shale.

Lower Cretaceous-Thermopolis Shale:

Upper sandstone member:

Ft In.

19. Sandstone, thin-bedded, silty, micaceous, glauconitic, feldspathic, slightly calcareous, very fine to fine-grained, lightgray; contains reddish-orange specks of hematite; angular grains... . . . ........

18. Mudstone, thin-bedded to massive, silty, micaceous, pyritic, dark-gray; contains thin in terbedded siltstone........

17. Sandstone, thin- to thick-bedded, wellindurated micaceous, pyritic, very fine to fine-grained, greenish-gray ( $5 G 6 / 1)$; weathers to dark yellowish brown $(10 Y R$ 4/2); contains a heavy-mineral suite and a few sporadic claystone pebbles

Total thickness of upper sandstone member.

Middle shale member:

16. Siltstone, thin-bedded, sandy, micaceous, slightly calcareous, light-medium-gray (transitional unit between underlying shale and overlying sandstone) .....

15. Mudstone, thin-bedded to massive, silty, micaceous, pyritic, dark-brownish-gray slightly carbonaceous near top of unit:

Ft In. 


\section{SECTION 6-Continued}

Reference section of the Skull Creek shale, measured in the $S W 14$ sec. 25, T. 49 N., R. 89 W., near Buffalo, Wyo.-Continued

Lower Cretaceous-Skull Creek Shale-Continued

5. Siltstone, tan to light-gray, calcareous, thinbedded, contains a few plant fragments; forms ledge.

4. Shale and siltstone, interbedded and interlaminated; becomes more silty toward top; grayish-black shale; brown siltstone........

3. Siltstone, brown, calcareous, thin-bedded; contains a few large steel-gray calcareous siltstone concretions; forms ledge.

2. Shale and siltstone, interbedded and interlaminated; grayish-black shale; brown siltstone. USGS Paleobotany loc. D3842-B, 39 $\mathrm{ft}$ above base of unit; USGS Paleobotany loc. D3842-A, $23 \mathrm{ft}$ above base of unit...---

1. Shale, gray to black, bentonitic; a zone of ferruginous siltstone concretions near middle of unit; poorly exposed

Total thickness of Skull Creek Shale

190 $174 \quad 6$

Lower Cretaceous-Cloverly Formation.

\section{MOWRY SHALE}

Two stratigraphic sections of the Mowry Shale are considered to be representative of the formation in the area west of Livingston. Section 7 was measured on the north side of Rocky Creek Canyon, and section 8 was measured on the north side of Canyon Mountain. The sequence at Rocky Creek Canyon is dominantly tuffaceous and carbonaceous, which suggests relative quiet brackish-water deposition. The sequence at Canyon Mountain is dominantly massive-bedded mudstone and silty shale, which suggests shallow restricted marine deposition. The section in Rocky Creek Canyon is here designated a reference section because of its microflora (table 2) and accessibility. Section 9, the Mowry Shale section of Mapel $(1959$, p. 42$)$, was sampled for paleobotanical control for measured sections 7 and 8 ; it is included here as the typical section of the Mowry Shale.

\section{SECTION 7}

Reference section of the Mowry Shale, measured on the north side of Rocky Creek Canyon in the $S W 1 / 4$ sec. 20, T. 2 S., R. 7 E., Gallatin County, Mont.

[Measured by A. E. Roberts, 1964]

Upper Cretaceous-Frontier Formation.

Lower Cretaceous-Mowry Shale:

28. Shale and mudstone, tuffaceous, brownishgray $(5 Y R \quad 4 / 1)$ and grayish-olive-green $(5 G Y 3 / 2)$; weathers to yellowish gray ( $5 Y$ $7 / 2$ ); contains some (approximately 25 percent) interbedded siltstone and porcelanitic sandstone; very poorly exposed ........... 185

27 . Bentonite, badly weathered and poorly exposed.

$\begin{array}{cc}85 & 0 \\ 2 & 0\end{array}$

\section{SECTION 7-Continued}

Reference section of the Mowry Shale, measured on the north side of Rocky Creek Canyon in the SW1/4 sec. 20. T. 2 S., R. 7 E., Gallatin County, Mont.-Continued

Lower Cretaceous-Mowry Shale-Continued

Ft In.

20. Sandstone, thin- to medium-bedded, very fine to fine-grained, indurated, calcareous, lightolive-gray ( $5 Y 6 / 1)$; weathers to yellowish gray $(5 Y 8 / 1)$. Unit contains approximately 20 percent interbedded claystone........

25. Shale, tuffaceous, brownish-gray (5YR 4/1); weathers to yellowish gray $(5 Y 7 / 2)$ and light gray (N7). Between 7 and $13 \mathrm{ft}$ above base, unit contains some thin interbedded very fine grained sandstone.......................

24. Sandstone, thin- to thick-bedded, fine- to coarse-grained, poorly sorted, indurated, calcareous, light-olive-gray ( $5 Y 6 / 1)$; weathers to yellowish gray $(5 Y 8 / 1)$. Between 9 and $11 \mathrm{ft}$ above base, unit is very fine grained to

silty and is thin bedded.
23. Shale, tuffaceous, brownish-gray $(5 Y R 4 / 1)$; $14 \quad 10$ weathers to yellowish gray $(5 Y 7 / 2)$ and light gray $(N 7)$

22. Siltstone, thin-bedded, calcareous, indurated carbonaceous, medium-gray (N5); weathers to grayish yellow green $(5 G Y 7 / 2) \ldots$

21. Shale, tuffaceous, brownish-gray $(5 Y R 4 / 1)$; weathers to yellowish gray $(5 Y 7 / 2)$ and light gray $(N 7)$

20. Sandstone, thin-to thick-bedded, fine- to coarsegrained, poorly sorted, indurated, calcareous, light-olive-gray ( $5 Y$ 6/1); weathers to yellowish gray ( $5 Y 8 / 1)$; contains zones of abundant clay pebbles and cobbles and some large plant fragments .................

19. Shale, tuffaceous, brownish-gray ( $5 Y R \quad 4 / 1)$ weathers to pinkish gray $(5 Y R 8 / 1)$. At 30 $\mathrm{ft}$ above base, a 1 -ft-thick layer of very carbonaceous claystone contains thin streaks of

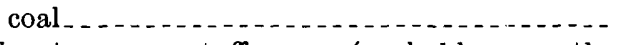

18. Claystone, very tuffaceous (probably a weathered bentonite), olive-gray ( $5 Y 4 / 1)$; weath-

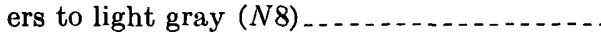

17. Claystone, light-olive-gray $(5 Y 6 / 1)$ at base; gradually darkens upward to olive black (5Y 2/1). Upper part contains reddish-orange specks of heulandite....................

16. Sandstone, thin-bedded, very fine grained, silty, friable, light-gray $(N 7)$; weathers to light olive gray $(5 Y 5 / 2)$.

15. Siltstone, thin-bedded, indurated, calcareous, carbonaceous, medium-gray $(N 5)$; weathers to grayish yellow green $(5 G Y 7 / 2) \ldots \ldots$

14. Sandstone, thin-bedded, very fine grained, silty, tuffaceous, friable, light-gray $(N 7)$; weathers to light olive gray $(5 Y 5 / 2) \ldots \ldots$

13. Claystone, tuffaceous, olive-gray (5Y $4 / 1)$; weathers to yellowish gray $(5 Y 8 / 1) \ldots \ldots$

12. Bentonite . . . . . . . . . . . .

11. Claystone, carbonaceous, brownish-black (5 $Y R 2 / 1)$; weathers to light brownish gray (5YR 6/1) ........................... 1 


\section{SECTION 7-Continued}

Reference section of the Mowry Shale, measured on the north side of Rocky Creek Canyon in the SW1/4 sec. 20, T. 2 S., R. 7 E., Gallatin County, Mont.-Continued

Lower Cretaceous-Mowry Shale-Continued

10. Sandstone, thin-bedded, very fine grained, silty, tuffaceous, friable, light-gray $(N 7)$; weathers to light olive gray $(5 Y 5 / 2)$; contains plant fragments. Approximately 90 percent of unit is composed of uncemented

9. Claystone, tuffaceous, grayish-olive-green $(5 G Y$ $3 / 2)$; weathers to pale olive $(10 Y 6 / 2)$

8. Sandstone, thin-bedded, very fine grained silty, light-gray $(N 7)$; weathers to light olive gray $(5 Y 5 / 2)$

7. Claystone, tuffaceous, grayish-olive-green ( $5 G Y$ $3 / 2)$; weathers to pale olive $(10 Y 6 / 2) \ldots . .$.

6. Sandstone, thin-bedded, very fine grained, silty, light-gray $(N 7)$; weathers to light olive gray $(5 Y 5 / 2) \ldots$

5. Claystone, tuffaceous, olive-gray (5Y 4/1); weathers to yellowish gray $(5 Y 8 / 1)$. USGS Paleobotany loc. D3513-B . . . . . . . . . .

4. Sandstone, thin-bedded, very fine grained, silty, light-gray (N7); weathers to light olive gray $(5 Y 5 / 2) \ldots \ldots \ldots$

3. Claystone, tuffaceous, grayish-olive-green $(5 G Y 3 / 2)$; weathers to pale olive (10Y 6/2) _.

2. Sandstone, thin-bedded, very fine grained, silty, light-gray (N7); weathers to light olive gray $(5 Y 5 / 2)$

1. Claystone, tuffaceous, light-olive-gray ( $5 Y 6 / 1)$ at base; gradually darkens upward to olive black $(5 Y 2 / 1)$. Upper 6 in. is very carbonaceous-almost a dirty coal. USGS Paleobotany loc. D3513-A_._...........

Total thickness of Mowry Shale Ft In.

16

14

18

42

20

$5 \quad 10$

10

114

20 30 $497 \quad 0$

Lower Cretaceous-Thermopolis Shale.

\section{SECTION 8}

Composite section of the Mowry Shale, measured on the north side of Canyon Mountain in sec. 34, T. 2 S., R. 9 E., and adjusted with section of the Deerfield Oil Corp. Strong 1 well in sec. 11, T. 2 S., R. 9 E., Park County, Mont.

[Measured by A. E. Roberts, 1961]

Upper Cretaceous-Frontier Formation.

Lower Cretaceous-Mowry Shale:

17. Siltstone, thin-bedded, dark-grayish-brown...

16. Shale, silty, dark-grayish-brown

15. Shale, silty, dark-gray

14. Mudstone, massive, silty, mottled grayishgreen and grayish-brown; contains reddishbrown specks and floating sand grains...... -

13. Shale, silty, micaceous, pyritic, dark-brownishgray; contains very thin beds of coal and siltstone

$58 \quad 0$

12. Sandstone, medium-bedded, micaceous, glauconitic, very fine grained, greenish-gray .....

\section{SECTION 8-Continued}

Composite section of the Mowry Shale, measured on the north side of Canyon Mountain in sec. 34, T. 2 S., R. 9 E., and adjusted with section of the Deerfield Oil Corp. Strong 1 well in sec. 11, T. 2 S., R. 9 E., Park County, Mont.-Continued

Lower Cretaceous-Mowry Shale-Continued

Ft In.

11. Claystone, greenish-gray _._. 50

10. Siltstone, thin-bedded, micaceous, pyritic, gray $\ldots \ldots$

9. Shale, silty, micaceous, dark-grayish-brown.-- $4 \quad 4 \quad 0$

8. Sandstone, medium-bedded, slightly calcareous, micaceous, pyritic, very fine to fine-grained, light-greenish-gray; subrounded grains .......

7. Siltstone, thin-bedded, gray; contains interbedded gray shale; siltstone contains reddishbrown specks. . .

6. Shale, silty, micaceous, pyritic, dark-gray; contains thin interbedded siltstone.........

5. Mudstone, thin-bedded to massive, silty, micaceous, pyritic, dark-brownish-gray mottled with red and green; contains thin interbedded siltstone.........................

4. Sandstone, thin-bedded, micaceous, glauconitic, indurated, greenish-gray; angular grains.

3. Mudstone, thin-bedded to massive, silty, micaceous, pyritic, dark-brownish-gray; contains thin interbedded siltstone........

2. Shale, glauconitic, greenish-gray

1. Mudstone, thin-bedded to massive, silty, micaceous, pyritic, dark-brownish-gray; contains thin interbedded siltstone and very fine grained sandstone

Total thickness of Mowry Shale $420 \quad 0$

Lower Cretaceous-Thermopolis Shale.

\section{SECTION 9}

Typical section of the Mowry Shale, measured about one-half of a mile north of the North Fork of Sayles Creek in secs. 5 and 6, T. 51 N., R. 83 W., near Buffalo, Wyo.

[Modified from Mapel (1959, p. 42)]

Upper Cretaceous-Frontier Formation.

Lower Cretaceous-Mowry Shale:

Siliceous shale member:

Ft In

23. Shale, dark-gray to black; weathers to dark gray. Brittle 6-in.-thick bed of hard silty sandstone near middle of unit; USGS Paleobotany loc. D3843-F, $10 \mathrm{ft}$ above base of unit.........

22. Sandstone, silty to very fine grained, thinbedded; forms ledge...............

21. Bentonite, pale-yellow

20. Shale, gray, siliceous, brittle; weathers to light gray; contains abundant fish scales. USGS Paleobotany loc. D3843-E, $2 \mathrm{ft}$ above base of unit_..._.

19. Siltstone, light-gray, hard; forms ledge -- $\begin{array}{lll}2 & 0\end{array}$

18. Shale, dark-gray; weathers to light gray; contains a few beds of light-gray siltstone......................... 580

17. Bentonite, pale-green to light-gray _... 20 


\section{SECTION $9-$ Continued}

Typical section of the Mowry Shale, measured about one-half of a mile north of the North Fork of Sayles Creek in secs. 5 and 6 , T. 51 N., R. 89 W., near Buffalo, Wyo.-Continued

Lower Cretaceous-Mowry Shale-Continued

Siliceous shale member-Continued

16. Shale, gray, siliceous, brittle; weathers to light gray; contains abundant fish scales and several thin beds of bentonite less than $1 \mathrm{ft}$ thick. USGS Paleobotany loc. D3843-D, $30 \mathrm{ft}$ above base of unit . . . 110

15. Bentonite, light-gray _...............

14. Shale, gray, brittle, locally slightly silty; weathers to light gray ...........

13. Bentonite, light-gray

12. Shale, gray, brittle; weathers to light gray; contains several thin beds of bentonite less than $1.5 \mathrm{ft}$ thick........

11. Bentonite, light-gray _.....

10. Shale, gray, brittle; weathers to light gray; contains fish scales; thin beds of bentonite about $1 \mathrm{ft}$ thick near middle

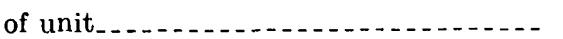

Total thickness of siliceous shale member

Black shale member:

9. Mostly concealed; appears to be mainly soft black shale that contains ironstone concretions which weather. to purplish black; USGS Paleobotany loc. D3843-C, $11 \mathrm{ft}$ above base of unit..........

8. Bentonite, light-yellowish-gray .........

7. Shale, grayish-black, soft, poorly exposed.-

6. Bentonite, light-gray . .

5. Shale, grayish-black, poorly exposed; contains a few ironstone concretions. . . . . .

4. Bentonite, light-gray _...

3. Shale, grayish-black, soft, bentonitic. USGS Paleobotany loc. D3843-B, $13 \mathrm{ft}$ above base of unit.

2. Bentonite, grayish-yellow

1. Shale, grayish-black; slightly sandy in lower part. USGS Paleobotany loc. D3843-A, $5 \mathrm{ft}$ above base of unit

Total thickness of black shale member \begin{tabular}{rr}
$\overline{202}$ & 0 \\
\hline \hline 527 & 0
\end{tabular}

Lower Cretaceous-Newcastle Sandstone.

\section{FRONTIER FORMATION}

One stratigraphic section of the Frontier Formation, section 10 , is considered to be representative of the formation in the area west of Livingston. The section was measured on the north side of Canyon Mountain. This readily accessible section is here designated a reference section.

\section{SECTION 10}

Reference section of the Frontier Formation, measured on the north side of Canyon Mountain in secs. 26 and $27, T$. $2 S$., R. $9 E$., Park County, Mont.

[Measured by A. E. Roberts and J. S. Hollingsworth, 1955]

Upper Cretaceous-Cody Shale.

Upper Cretaceous-Frontier Formation:

27. Sandstone, massive, micaceous, very fine to fine-grained, indurated, light-greenish-gray (5GY 7/1); weathers to medium light gray (N6) and contains reddish-brown specks of hematite; ridge former. . . . . . . . . . . . . . .

26. Sandstone, thin-bedded, micaceous, very fine

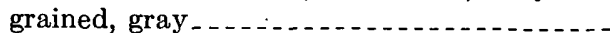

25. Shale, silty, dark-gray to black

24. Sandstone, thin-bedded, silty, micaceous, very fine grained, gray . . . . . . . . . . . .

23. Sandstone, thin- to medium-bedded, silty, very fine grained, micaceous, calcareous, indurated, light-greenish-gray (5GY $7 / 1)$; weathers to yellowish orange $(10 Y R 7 / 6)$; ridge former.

22. Sandstone, thin-bedded, silty, calcareous, carbonaceous, very fine grained, medium-gray -

21. Siltstone, thin-bedded, carbonaceous, micaceous, medium-gray . . . . . . . . . .

20. Shale, silty, carbonaceous, micaceous, pyritic, dark-gray; contains streaks of siltstone .....

19. Siltstone, thin-bedded, calcareous, mediumlight-gray _. . . . . . . . . . . . . .

18. Sandstone, medium-bedded, silty, micaceous, carbonaceous, very fine to fine-grained, indurated, light-greenish-gray (5GY 8/1); weathers to light olive gray $(5 Y 6 / 1) \ldots \ldots$

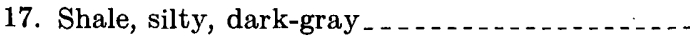

16. Conglomerate; pebbles less than 2 in. in diameter of well-rounded chert in sand matrix; " $C$ " bed on geologic maps (Roberts, 1964b, $\mathrm{e}$, and $\mathrm{f}$ ) .

15. Sandstone, massive to crossbedded, yellowishgray ( $5 Y 8 / 1)$, poorly sorted, pebbly; prominent ridge former; weathers to dark yellowish-orange $(10 Y R 6 / 6)$. Sand grains are chiefly quartz, feldspar, and gray or brown chert that are angular to subrounded....

14. Siltstone, thin-bedded, indurated, dark-gray - -

13. Sandstone, medium-bedded, calcareous, feldspathic, glauconitic, very fine to finegrained, gray; contains sporadic chert

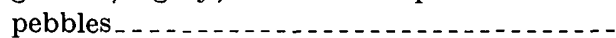

12. Siltstone, thin- to medium-bedded, greenishgray $(5 G Y 6 / 1)$; weathers to yellowish gray $(5 Y 8 / 1) \ldots$

11. Sandstone, thin- to medium-bedded, greenishgray $(5 G Y 6 / 1)$, very fine grained, indurated; ridge former; weathers to a mottled surface of yellowish gray $(5 Y$ 8/1) and light gray $(N 7)$; contains heavy-mineral suite concentrated in very thin bands.......
Ft In. 


\section{SECTION 10-Continued}

Reference section of the Frontier Formation, measured on the north side of Canyon Mountain in secs. 26 and $27, T$. Q S., R. 9 E., Park County, Mont.-Continued

Upper Cretaceous-Frontier Formation-Continued
10. Sandstone, thick and crossbedded, light-gray (N7), very fine- to fine-grained, slightly calcareous; weathers to yellowish-gray ( $5 Y 8 / 1)$; contains a heavy-mineral suite, commonly in dark bands 0.25 in. or less in thickness . -

9. Siltstone, platy to thin-bedded, feldspathic, glauconitic, grayish-olive $(10 Y 4 / 2)$ to olivegray $(5 Y 3 / 2)$; weathers to light olive gray (5Y 5/2); contains a few interbeds of thinbedded, very fine grained, calcareous sandstone and dark-grayish-brown carbonaceous shale that includes very thin beds of coal....

8. Sandstone, thin- to thick-bedded, crossbedded, grayish-yellow-green $(5 G Y 7 / 2)$, fine- to coarse-grained, micaceous, glauconitic, indurated; weathers to dark yellowish brown $(10 Y R 4 / 2)$; contains a heavy-mineral suite; very prominent ridge former.............

7. Shale, silty, dark-brown; contains very thin

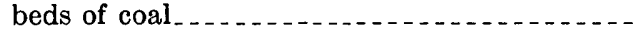

Boulder River Sandstone Member:

6. Sandstone, thin-bedded, mottled dark-gray (N3) and medium-light-gray (N6), very fine grained, feldspathic, micaceous; weathers to a mottled greenish gray $(5 G Y 6 / 1)$ and very light gray (N8). Mottling due to crystal clusters of analcime in the cementing material. " $\mathrm{A}$ " bed on geologic maps (Roberts, 1964b, d-f, and h) -

5. Sandstone, thin-bedded, silty, very fine grained, grayish-green; contains interbedded silty darkgrayish-brown shale....................

4. Sandstone, thin-bedded, grayish-olive-green ( $5 G Y 3 / 2)$, very fine grained, calcareous, micaceous; weathers to light olive gray $(5 Y 5 / 2)$ and contains reddish-brown specks -

3. Sandstone, massive, light-gray $(N 7)$, very fine to fine-grained, poorly sorted; weathers to yellowish gray $(5 Y 7 / 2)$; calcareous and more indurated in upper 5 in.; contains a heavymineral suite; contains sporadic rounded dark-gray $(N 3)$ chert pebbles and a few small channel-fill deposits of chert pebbles and granule-size sand near top (fig. 9)

2. Sandstone, very thin bedded, grayish-yellow green $(5 G Y 7 / 2)$, silty, very fine grained, calcareous, micaceous, glauconitic; weathers to light olive gray $(5 Y$ 6/1) and contains reddish-brown specks; contains Inoceramus

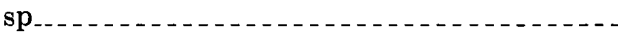

1. Sandstone, thin- to thick-bedded, crossbedded, grayish-green $(10 G Y 5 / 2)$, very fine to finegrained, micaceous, glauconitic, feldspathic, calcareous, poorly sorted; weathers to brownish gray (5YR 4/1); contains heavy-mineral suite; contains a few interbeds of very thin to thin-bedded siltstone. Almost every bedding plane has a ripple-marked surface, and $\begin{array}{ll}70 & 0\end{array}$
SECTION 10-Continued

Reference section of the Frontier Formation, measured on the north side of Canyon Mountain in secs. 26 and 27, T. \& S., R. 9 E., Park County, Mont.-Continued

Ft. In. Upper Cretaceous-Frontier Formation-Continued

Boulder River Sandstone Member-Continued Ft In. many have abundant casts and molds of Ophiomorpha and other burrows (fig. 10). A few poorly preserved plant fragments were also noted

Total thickness of Boulder River Sandstone Member. .... 1190

Total thickness of Frontier Formation_ _. $\overline{4415 \quad 0}$ Lower Cretaceous-Mowry Shale.

\section{CODY SHALE}

The Cody Shale is not well exposed in the area west of Livingston. The most complete section was measured on the north side of Canyon Mountain, and descriptions of the covered intervals in this section were added from the Deerfield Oil Corp. Strong 1 well. The description of section 11 is considered to be typical of the formation for this area.

\section{SECTION 11}

Composite section of the Cody Shale, measured on the north side of Canyon Mountain in sec. 27, T. 2 S., R. 9 E., and adjusted with section of the Deerfield Oil Corp. Strong 1 well in sec. 11, T. 2 S., R. 9 E., Park County, Mont.
450

$2 i \quad 0$
[Measured by A. E. Roberts, 1961]

Upper Cretaceous-Telegraph Creek Formation.

Upper Cretaceous-Cody Shale:

Upper shale member:

Ft In

32. Siltstone, thin-bedded to massive, micaceous, calcareous, dark-gray to darkbrownish-gray _..................

31. Sandstone, thin-bedded, silty, micaceous, calcareous, pyritic, very fine to fine-grained; contains thin interbedded dark-brownish-gray shale.-.-

30. Shale, calcareous, dark-brownish-gray; contains thin interbedded dark-gray siltstone ..................

29. Sandstone, thin- to medium-bedded, silty, calcareous, pyritic, glauconitic, micaceous, very fine grained; contains thin interbedded calcareous dark-brownish-gray shale_._. _. _. _. _

28. Mudstone, thin-bedded to massive, silty, pyritic, dark-brownish-gray; contains thin interbedded calcareous

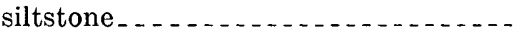

27. Sandstone, thin- to medium-bedded, silty, calcareous, pyritic, glauconitic, micaceous, very fine to fine-grained, gray; contains thin interbedded silty dark-brownish-gray shale; bears red specks of heulandite(?) ............. 


\section{SECTION 11-Continued}

Composite section of the Cody Shale, measured on the north side of Canyon Mounlain in sec. $27, T$. 2 S., R. 9 E., and adjusted with section of the Deerfield Oil Corp: Strong 1 well in sec. 11, T. \& S., R. 9 E., Park County, Mont.-Continued

Upper Cretaceous-Cody Shale-Continued

Upper shale member-Continued

26. Mudstone, massive, silty, pyritic, darkbrownish-gray

25. Siltstone, thin- to medium-bedded, micaceous, pyritic, gray; contains thin interbedded silty dark-brownishgray shale............

24. Mudstone, massive, silty, calcareous, micaceous, pyritic, dark-brownish-

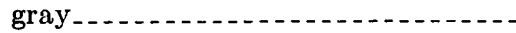

23. Sandstone, thin- to medium-bedded, fine- to coarse-grained, subrounded grains, light-gray ................

22. Shale, silty, calcareous, pyritic, darkgrayish-brown; contains thin interbedded siltstone.

21. Sandstone, thin- to medium-bedded, calcareous, glauconitic, micaceous, very fine grained; contains thin interbedded silty, calcareous, darkgrayish-brown shale................

20. Mudstone, thin- to thick-bedded, silty, calcareous, sideritic, pyritic, darkgrayish-brown; contains thin interbedded, fine- to coarse-grained, quartzose, light-gray sandstone that bears subrounded grains............

19. Sandstone, thin-bedded, silty, calcareous, pyritic, micaceous, very fine to fine-grained, gray; contains interbedded silty, dark-grayish-brown shale. - . - .

18. Siltstone, thin-bedded, sandy, calcareous, micaceous, sideritic, gray ........

17. Shale, pyritic, dark-gray to darkbrownish-gray; contains thin interbedded gray siltstone.............

16. Siltstone, thin-bedded, sandy, calcareous, micaceous, sideritic, gray; contains interbedded dark-gray shale _. . -

15. Sandstone, medium-bedded, silty, calcareous, micaceous, very fine grained, white . . . . . . . . . . .

14. Shale, silty, calcareous, pyritic, micaceous, dark-gray; contains thin, interbedded, calcareous, gray siltstone.... -

Total thickness of upper shale member

\begin{tabular}{rr}
$575 \quad 0$ \\
\hline
\end{tabular}

Eldridge Creek Member:

13. Sandstone, platy to thin-bedded, silty, calcareous, very glauconitic, micaceous, pyritic, very fine grained,
SECTION 11-Continued

Composite section of the Cody Shale, measured on the north side of Canyon Mountain in sec. 27, T. 2 S., R. 9 E., and adjusted with section of the Deerfield Oil Corp. Strong 1 well in sec. 11, T. \& S., R. 9 E., Park County, Mont.-Continued

Upper Cretaceous-Cody Shale-Continued

Eldridge Creek Member-Continued

greenish-gray; weathers to grayish yellow green; contains thin interbedded calcareous siltstone and silty, calcareous, dark-brownish-gray shale; fossiliferous; USGS Mesozoic loc. D581; slight ridge former (fig. 11) . .

Total thickness of Eldridge Creek Member

Lower shale member:

12. Shale, silty, calcareous, micaceous, pyritic, dark-brownish-gray; contains thin interbedded very fine grained sandstone and siltstone.

11. Shale, silty, calcareous, micaceous, pyritic, glauconitic, dark-grayish-brown; contains lenses of gray siltstone ..... -

10. Siltstone, thin-bedded, shaly, calcareous, micaceous, pyritic, glauconitic, gray; contains thin interbedded darkgray, silty shale.....................

9. Shale, silty, calcareous, micaceous, glauconitic, dark-brownish-gray; contains thin interbedded, very fine grained, calcareous, gray sandstone and siltstone; calcareous concretions (commonly septarian)

8. Siltstone, thin-bedded, clayey, calcareous, micaceous, glauconitic, darkgrayish brown ..................

7. Shale, silty, micaceous, pyritic, dark-

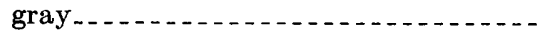

6. Shale, silty, calcareous, micaceous, pyritic, dark-gray; contains thin interbedded very fine grained, silty, calcareous sandstone

5. Shale, silty, micaceous, pyritic, darkbrownish-gray; contains thin interbedded calcareous siltstone; fossiliferous; bentonite bed near middle of unit .

4. Sandstone, medium-bedded, conglomeratic, calcareous, micaceous, very fine to coarse-grained; contains pebbles of well-rounded chert.

3. Shale, silty, calcareous, micaceous, pyritic, dark-grayish-brown ...........

2. Sandstone, medium-bedded, indurated, very fine grained, light-greenish-gray; weathers to yellowish orange; contains heavy-mineral suite including much biotite; ridge former
650

100

$20 \quad 0$

30. 0

$100 \quad 0$

40

$6 n$

n 


\section{SECTION $11-$ Continued}

Composite section of the Cody Shale, measured on the north side of Canyon Mountain in sec. 27, T. 2 S., R. 9 E., and adjusted with section of the Deerfield Oil Corp. Strong 1 well in sec. 11, T. 2 S., R. 9 E., Park County, Mont.-Continued

Upper Cretaceous-Cody Shale-Continued

Lower shale member-Continued

1. Shale, silty, calcareous, micaceous, pyritic, dark-gray to dark-brownish-gray; contains thin interbedded calcareous gray siltstone; bentonite bed near middle of unit.

Total thickness of lower shale member_ $\quad 590 \quad 0$

Total thickness of Cody Shale_... _. 1, 2850 Upper Cretaceous-Frontier Formation.

\section{TELEGRAPH CREEK FORMATION}

Two stratigraphic sections of the Telegraph Creek Formation are considered to be representative of the formation in the area west of Livingston. These are measured section 12, near the abandoned townsite of Cokedale, Mont., and measured section 13, on the north side of Canyon Mountain. The sequence at Cokedale is siltstone and sandstone at a ratio of approximately three to one. The sequence at Livingston is approximately a third of shale and mudstone and two-thirds of siltstone and sandstone.

\section{SECTION 12}

Telegraph Creek Formation, measured in the $N W 1 / 4$ sec. 26, T. 2 S., R. 8 E., Park County, Mont.

[Measured by A. E. Roberts and J. S. Hollingsworth, 1955]

Upper Cretaceous-Eagle Sandstone.

Upper Cretaceous-Telegraph Creek Formation: $\quad$ Ft $\quad$ In.

10. Sandstone, thin-bedded ( 0.5 in. or less), lightgray $(N 7)$, fine-grained, quartzose, very calcareous; weathers to yellowish gray (5Y 7/2); contains heavy-mineral suite; has salt-and-pepper appearance. Unit is very uniform throughout................

9. Siltstone, thin-bedded to massive, sandy; contains thin interbedded, very fine grained, quartzose sandstone. This unit is poorly exposed. Siltstone is generally mottled olive gray (5Y 4/1) and dark greenish gray ( $5 G Y 4 / 1)$, is generally carbonaceous, contains disseminated plant fragments, and weathers to pale olive $(10 Y 6 / 2)$. Unit resembles a brackish-water tidal-flat deposit. Sandstone is very minor, 5 percent estimate, and is thin bedded ( 0.5 in. or less) and generally very calcareous.........

8. Siltstone, massive, medium-dark-gray $(N 4)$, slightly carbonaceous; weathers to a yellowish gray $(5 Y 7 / 2)$; very calcareous

\section{SECTION 12-Continued}

Telegraph Creek Formation, measured in the $N W 1 / 4$ sec. 26, T. 2 S., R. 8 E., Park County, Mont.-Continued

Upper Cretaceous-Telegraph Creek Formation-Con. Ft In

7. Sandstone, thin-bedded to massive, very fine grained, very calcareous, light-gray $(N 7)$, quartzose, indurated; contains some disseminated plant fragments; contains heavymineral suite; ripple marked; weathers to yellowish gray (5Y 7/2). Worm(?) tubes noted on bedding surfaces

6. Siltstone, thin-bedded, olive-gray ( $5 Y 4 / 1)$, slightly carbonaceous, very calcareous; contains some disseminated plant fragments; weathers to yellowish gray ( $5 Y$ $7 / 2)$

5. Sandstone, thin-bedded, light-olive-gray $(5 Y$ $6 / 1$ ), very calcareous, indurated, very fine grained, quartzose; weathers to yellowish gray $(5 Y 7 / 2)$

4. Siltstone, thin-bedded, (bedding is 0.5 in. thick or less), olive-gray (5Y 4/1), slightly carbonaceous, very calcareous; contains disseminated plant fragments; weathers to yellowish gray $(5 Y 7 / 2)$

3. Sandstone, thick-bedded, very calcareous, very fine grained, light-olive-gray $(5 Y 6 / 1)$, indurated, quartzose. Pronounced spheroidal weathering in large concentric sheets. The unit is continuous, but the spheroidal weathering makes it appear concretionary

2. Siltstone, thin-bedded, olive-gray $(5 Y 4 / 1)$, slightly carbonaceous, very calcareous; weathers to yellowish gray $(5 Y 7 / 2) \ldots \ldots$

1. Concealed; probably thin-bedded siltstone and fine-grained sandstone...........

Total thickness of 'Telegraph Creek Formation

Upper Cretaceous-Cody Shale.

\section{SECTION 13}

Composite section of the Telegraph Creek Formation, measured on the north side of Canyon Mountain in sec. 27, T. 2 S., R. 9 E.; and adjusted with the section of the Deerfield Oil Corp. Strong 1 well in sec. 11, T. 2 S., R. 9 E., Park County, Mort.

[Measured by A. E. Roberts, 1961]

Upper Cretaceous-Eagle Sandstone.

Upper Cretaceous-Telegraph Creek Formation: Ft In.

11. Siltstone, thin-bedded, sandy, micaceous, pyritic, sideritic, medium-gray; contains interbedded shale .........................

10. Sandstone, thin-bedded, silty, micaceous, pyritic, very fine grained..................

9. Siltstone, massive, sandy, micaceous, calcareous, pyritic, dark-gray; contains thin interbedded shale and very fine grained

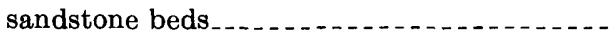

8. Mudstone, massive, micaceous, sandy, calcareous, dark-brownish-gray . . . . . . . . . .....

7. Sandstone, thin-bedded, silty, micaceous, pyritic, calcareous, very fine to medium-grained, gray; contains interbedded shale . . . . . . . 30

$\begin{array}{ll}40 & 0 \\ 15 & 0 \\ & \\ 40 & 0 \\ 15 & 0 \\ & \\ 30 & 0\end{array}$




\section{SECTION 13-Continued}

Composite section of the Telograph Creek Formation, measured on the north side of Canyon Mountain in stc. 27, T. $2 S ., R .9$ E.; and adjusted with the section of the Deerfield Oil Corp. Strong.1 well in. sec. 11, T. \& S., R. 9 E., Park County, Mont.-Con.

Upper Cretaceous-Telegraph Creek Formation-Con. Ft In.

6. Shale, silty, micaceous, pyritic, calcareous, dark-brownish-gray; contains thin interbedded very fine grained sandstone........

5. Sandstone, thin-bedded, silty, sideritic, feldspathic, very fine grained, gray . .......

4. Mudstone, thin-bedded to massive, silty; sideritic, calcareous, light-gray to gray and green; contains interbedded calcareous siltstone

3. Sandstone, thin-bedded, calcareous, pyritic, very fine grained, light-gray; contains abundant heavy minerals and thin, interbedded, calcareous, silty shale..................

2. Shale, silty, calcareous, dark-gray and brownish-gray

1. Sandstone, thin- to thick-bedded, silty, calcareous, feldspathic, micaceous, pyritic, sideritic, very fine to fine-grained, lightgray; contains abundant heavy minerals....

$30 \quad 0$

Total thickness of Telegraph Creek Formation . . . . 295

Upper Cretaceous-Cody Shale.

\section{EAGLE SANDSTONE}

Two stratigraphic sections of the Eagle Sandstone are considered to be typical of the formation in the area west of Livingston. These are measured section 14, near the abandoned townsite of Cokedale, Mont., and section 15, measured near Livingston, Mont., on the west side of the Yellowstone River. Comparison of these two stratigraphic sequences indicates that the sandstone has an eastward decrease in average grain size and that the formation has an eastward decrease in coal content and in thickness.

\section{SECTION 14}

Reference section of the Eagle Sandstone, measured on the north side of Miner Creek in the NW1/4 sec. 26, T. 2 S., R. 8 E., Park County, Mont.

[Messured by Albert E. Roberts and J. Stewart Hollingsworth in 1955]

Cokedale Formation (Upper Cretaceous).

Eagle Sandstone (Upper Cretaceous):

104. Sandstone, thick-bedded, indurated (slight ridge former), calcitic, very fine grained, light-olive-gray ( $5 Y 6 / 1)$, arkosic. Weathers to pale-olive $(10 Y 6 / 2)$ slabs about 3-6 in. thick. Sorting, fair. Quartz grains comprise 50 percent. Contains heavymineral suite.
Reference section of the Eagle Sandstone, measured on the north side of Miner Creek in the NW1/4 sec. 26, T. 2 S., R. 8 E., Park County, Mont.-Continued

Eagle Sandstone (Upper Cretaceous)-Continued Ft In.

103. Siltstone, thick-bedded, tuffaceous, olivegray $(5 Y 4 / 1)$, and thin interbedded very fine grained sandstone Weathers to dusky yellow (5Y 6/4). Contains fragments (fine grained) of volcanic rocks and plant fragments. Unit poorly exposed..-

102. Siltstone, very carbonaceous, tuffaceous, clayey (roof)

101. Coal (Cokedale coal bed or locally the Cokedale No. 5 bed), attitude N. $84^{\circ}$ W., $40^{\circ}$ $\mathrm{NE}$

Siltstone, very carbonaceous, tuff- in. aceous.................... 2

Siltstone, tuffaceous.

Bone............... 3

Coal

Siltstone, altered, tuffaceous, carbonaceous................ 2.5

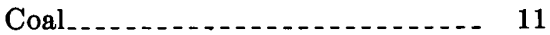

Siltstone, altered, tuffaceous, carbonaceous.......................

Bone.

Coal

Bone . . . . . . . . . . . . 2

Siltstone, very carbonaceous, clayey . . . . 6

100. Siltstone, massive, light-gray (N7), clayey. Poorly exposed. Weathers to light-olivegray $(5 Y 6 / 1)$ soil

99. Sandstone, indurated (slight ridge former), very fine grained, dusky-yellow-green (5GY 5/2). Sorting, fair. Weathers to yellowish orange $(10 Y R$ 7/6). Rock appears to be transition of Eagle Sandstone and Livingston Group lithologies. Weathers along fractures (N. $60^{\circ}$ W.) and bedding planes. Attitude N. $80^{\circ}$ W., $40^{\circ}$ $\mathrm{NE}$

98. Siltstone, thick-bedded, light-olive-gray ( $5 Y$ $6 / 1$ ), clayey, carbonaceous. Weathers to moderate yellowish brown (10YR 5/4). Small granule-size grains near base . .....

97. Coal (probably Paddy Miles coal bed or locally the Cokedale No. 4 bed)

Bone

年

Coal

96. Siltstone, medium-bedded, olive-gray (5Y 4/1). Weathers to moderate yellowish brown $(10 Y R$ 5/4) ............

95. Siltstone, very carbonaceous (almost bone) -

94. Siltstone, massive, pale-olive (10Y 6/2), tuffaceous. Weathers to moderate greenish yellow $(10 Y 7 / 4)$. Forms a crumbly soil

93. Sandstone, indurated, slabby, crossbedded, very fine grained, yellow-green ( $5 G Y 6 / 2)$; slight ridge former. Irregular thickness, from 4 to $6 \mathrm{ft}$ 
Reference section of the Eagle Sandstone, measured on the north side of Miner Creek in the NW1/4 sec. 26, T. 2 S., R. 8 E., Park Counly, Mont.-Continued

Eagle Sandstone (Upper Cretaceous) - Continued

92. Siltstone, massive, olive-gray ( $5 Y 4 / 1)$, car-

bonaceous. Poorly exposed.........

91. Siltstone, thick-bedded, medium-dark-gray

$(N 4)$, carbonaceous. Weathers to light olive gray (5Y 6/1). Slightly more indurated than overlying siltstone. Breaks with conchoidal fracture. Manganese stain common on fracture surfaces. Spheroidal weathering ......................

90. Coal, probably Storrs No. 3 coal bed (upper part); not described, as bed is burned along the outcrop from the valley to top of the

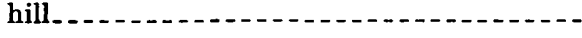

89. Siltstone, very carbonaceous, grayish-brown (5YR 3/2), weathers to pale yellowish brown $(10 Y R 6 / 2)$. Contains plant frag-

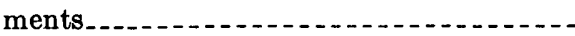

88. Siltstone, massive, greenish-gray ( $5 G Y 6 / 1)$. Weathers to yellowish gray (5Y 8/1). Poorly exposed.

87. Coal, probably Storrs No. 3 coal bed (lower part) ........

Bony coal.................... 1

Coal_._.

Siltstone, very carbonaceous_._._._. 3

Coal_...

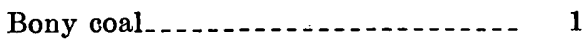

Siltstone, very carbonaceous....... 3

86. Siltstone, massive, light-olive-gray ( $5 Y 6 / 1$ ), tuffaceous; weathers to yellowish gray ( $5 Y$ 8/1). Poorly exposed._...

85. Sandstone, massive, very light gray (N8), fine-grained, arkosic. "Salt-and-pepper" appearance. Contains heavy-mineral suite. Somewhat porous; considerable limonitic staining near top of unit. Slightly crossbedded. Sorting, fair. Massive spheriodal weathering. Weathers to yellowish gray $(5 Y 7 / 2)$

84. Concealed; probably fine-grained very light gray arkosic sandstone................

83. Sandstone, massive, very light gray (N8), fine-grained, arkosic. "Salt-and-pepper" appearance. Contains heavy-mineral suite. Sorting, fair. Massive spheroidal weathering. Weathers to yellowish gray

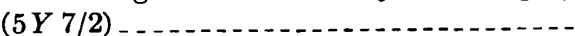

82. Sandstone, massive, slabby, arkosic, calcareous, mixture of very fine grained sand and pods or lenses of silt (definite brackishwater deposit), yellowish-gray (5Y 7/2). Mottled where silt is concentrated. Weathers to grayish yellow (5Y 8/4). Many worm tubes or pelecypod burrowings (some 12 in. long) .......

81. Siltstone, thick-bedded, mottled, yellowishgray $(5 Y 7 / 2)$, sandy. Brackish-water deposit. Weathers to grayish yellow (5Y

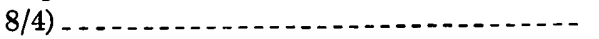

Ft In. 
Reference section of the Eagle Sandstone, measured on the north side of Miner Creek in the NW1/4 sec. 26, T. Q S., R. 8 E., Park County, Mont.-Continued

Eagle Sandstone (Upper Cretaceous)-Continued gray $(5 Y 7 / 2)$. Contains macerated plant fragments and heavy minerals..........

70. Sandstone, massive, very fine grained, lightolive-gray ( $5 Y 6 / 1)$, arkosic, very calcareous. Weathers to yellowish gray ( $5 Y$ $7 / 2$ ). Contains a few plant fragments and heavy minerals. Poorly developed spheroidal weathering.

69. Siltstone, platy ( $/ 8$ in. or less), olive-gray (5Y 4/1), slightly carbonaceous, very calcareous. Weathers to yellowish gray ( $5 Y$ $7 / 2)$

68. Sandstone, platy, very fine grained, lightolive-gray ( $5 Y 6 / 1)$, arkosic, very calcareous, indurated. Weathers to light olive gray $(5 Y 5 / 2)$. Contains heavymineral suite...........................

67. Siltstone, very carbonaceous. . . . . . . . .

66. Sandstone, massive, poorly indurated (except for very calcareous pods and lenses), poorly sorted, silty, very fine grained, arkosic, pale-olive $(10 Y 6 / 2)$; contains very calcareous pods and lenses. In places, mottled by concentration of silt. Typical of brackish-shallow-water deposit. Contains plant fragments and heavy minerals .... 2. .

65. Concealed; probably thin-bedded very fine grained arkosic sandstone. Considerable sandstone float for this interval .........

64. Sandstone, thin-bedded, light-olive-gray (5Y 6/1), fine-grained, arkosic, calcareous. Bedding $<1 / 4$ in. thick, marked by bands of heavy minerals. Weathers to yellowish-gray $(5 Y 7 / 2) \quad 1 / 2-2$-in. slabs. Contains disseminated plant fragments. Attitude N. $84^{\circ}$ W., $41^{\circ}$ NE. . . . . . . . . . . . .

63. Sandstone, thin-bedded, silty, very fine grained, arkosic, calcareous, light-olivegray $(5 Y$ 6/1). Weathers to yellowish gray $(5 Y 7 / 2)$. Less indurated than overlying sandstone. Base not exposed......

62. Concealed; probably thin-bedded silty very fine grained sandstone. ...............

61. Sandstone, thin-bedded, light-olive-gray ( $5 Y$ $6 / 1$ ), indurated (slight ridge former), very fine grained, calcareous. Weathers to yellowish-gray $(5 Y 6 / 2)$ slabs $1 / 2-2$ in. thick. Contains plant fragments and heavy-mineral suite

60. Concealed; probably thin-bedded silty very fine grained sandstone . . . . . . . . . . . .

59. Sandstone, platy, light-olive-gray ( $5 Y_{6 / 1}$ ), calcareous, arkosic, very fine grained. Weathers to slabs about $1 / 2$ in. thick. Contains heavy-mineral suite and plant fragments-one fair quality leaf impression noted. Attitude N. $89^{\circ}$ W., $42^{\circ}$ NE . ...

58. Concealed; probably thin-bedded silty very fine grained sandstone.
Ft In.

1

Reference section of the Eagle Sandstone, measured on the north side of Miner Creek in the NW1/4 sec. 26, T. 2 S., R. 8 E., Park County, Mont.-Continued

Eagle Sandstone (Upper Cretaceous) - Continued

57. Sandstone, platy, light-olive-gray ( $5 Y 6 / 1)$, calcareous, arkosic, very fine grained. Weathers to slabs about $1 / 2$ in. thick. Contains heavy-mineral suite and plant fragments.

56. Concealed; probably thin-bedded silty very fine grained sandstone . . . . . . . . . . . .

55. Sandstone, platy, indurated (slight ridge former), calcareous, arkosic, very fine grained, light-olive-gray (5Y 6/1). Angular to subangular grains. Sorting, fair. Crossbedded. Weathers to yellowish gray (5Y 7/2). Few poorly preserved leaf impressions. Calcite veinlets $<1 / 4$ in. thick along fracture surfaces................

54. Concealed; probably thin-bedded silty very fine grained sandstone . ..............

53. Sandstone, platy, indurated (slight ridge former), calcareous, arkosic, very fine grained, light-olive-gray (5Y6/1). Angular to subangular grains. Sorting, fair. Crossbedded. Weathers to yellowish gray (5Y 7/2) .............................

52. Concealed; probably thin-bedded silty very fine grained sandstone . . . . . . . . . . . . .

51. Sandstone, platy, indurated, calcareous, arkosic, very fine grained, light-olive-gray (5Y 6/1). Weathers to yellowish gray (5Y $7 / 2)$. Attitude N. $83^{\circ}$ W., $49^{\circ}$ NE ...

50. Concealed; probably thin-bedded silty very fine grained sandstone . . . . . . . . . . .

49. Sandstone, platy, indurated (slight ridge former), calcareous, arkosic, very fine grained, light-olive-gray (5Y6/1). Angular to subangular grains. Sorting, fair. Crossbedded. Weathers to yellowish gray (5Y 7/2) ..........................

48. Concealed; probably thin-bedded silty very fine grained sandstone. . . . . . . . .

47. Sandstone, platy, indurated (slight ridge former), calcareous, arkosic, very fine grained, light-olive-gray (5Y 6/1). Angular to subangular grains. Sorting, fair. Crossbedded. Weathers to yellowish gray (5Y 7/2)

46. Concealed; probably thin-bedded silty very fine grained sandstone . . . . . . . . . . .

45. Sandstone, platy, indurated (slight ridge former), calcareous, arkosic, very fine grained, light-olive-gray ( $5 Y$ 6/1). Angular to subangular grains. Sorting, fair. Crossbedded. Weathers to yellowish gray $(5 Y 7 / 2)$. Large very calcareous olive-gray ( $5 Y 5 / 1)$ concretionary lenses of sandstone (some as large as $2 \times 5 \mathrm{ft}$ ). They weather to yellowish gray $(5 Y 6 / 2)$ with pronounced spheroidal weathering-

44. Sandstone, platy, slightly indurated, arkosic, calcareous, very fine grained, lightolive-gray (5Y 6/1); interbedded thinbedded silty very fine grained sandstone. Weathers to yellowish gray $(5 Y 6 / 2) \ldots$

Ft In. 
Reference section of the Eagle Sandstone, measured on the north side of Miner Creek in the NW1/4 sec. 26, T. 2 S., R. 8 E., Park County, Mont.-Continued

Eagle Sandstone (Upper Cretaceous)-Continued

43. Sandstone, thin- to medium-bedded, indurated (slight ridge former), calcerous, very fine grained, arkosic, light-olive-gray ( $5 Y$ 6/1). Angular to subangular grains. Sorting, fair. Weathers to yellowish gray (5 $Y$ 6/2)

42. Sandstone, thin-bedded, silty, very fine grained, light-olive-gray $(5 \mathrm{Y} 6 / 1)$. Weathers to yellowish gray $(5 Y 6 / 1)$. Poorly exposed.

41. Tuff, microlitic, medium-bedded, mediumdark-gray (N4), indurated, silty, very fine grained, calcareous (few small secondary calcite crystals), andesitic. Angular grains. Poorly sorted. Weathers to olive gray $(5 Y 3 / 1)$. Rock composed mostly of volcanic rock fragments and plagioclase (andesine). Many vugs $<1 / 4$ in. in diameter. Attitude N. $68^{\circ}$ W., $38^{\circ}$ NE .. -

40. Sandstone, thick-bedded, dark-green ish-gray ( $5 G Y 4 / 1)$, poorly sorted, silty, mediumgrained, angular grains, slightly calcareous, andesitic. Composed of volcanic rock fragments and plagioclase. Weathers to greenish gray $(5 G Y$ 6/1). Faint, poorly formed bedding. Poorly sorted ...

39. Siltstone, massive, tuffaceous, light-olivegray $(5 Y 5 / 2)$. Contains disseminated plant fragments. Weathers to yellowish gray $(5 Y 7 / 2)$

Possible fault of less than a fow feet displacement.

38. Tuff, microlitic, massive, calcareous, mediumlight-gray (N6), indurated, very fine grained, andesitic. Angular grains. Poorly sorted. Breaks with conchoidal fracture. Composed of volcanic rock fragments and plagioclase (too altered for composition determination). Weathers to dark yellowish brown (10YR 4/2). Many small vugs - some coated first with calcite and later with silica

37. Coal (Middle coal bed or locally the Cokedale No. 3 bed)

Coal

Siltstone, carbonaceous . . . . . . . . . 1

Bone _. . . . . .

Siltstone, very carbonaceous........ 2

Siltstone, carbonaceous . . . . . . . . . 2

36. Sandstone, indurated, thin- to mediumbedded, fine-grained, slightly arkosic, yellowish-gray $(5 Y 7 / 2)$. Contains heavymineral suite. Weathers to yellowish

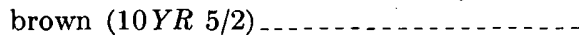

35. Siltstone, poorly exposed, carbonaceous _...

34. Sandstone, thin-bedded to massive, yellowishgray $(5 Y 7 / 2)$, slightly arkosic, very fine grained, very calcareous. Weathers to yellowish gray $(5 Y 6 / 2) \ldots \ldots . . . . . . . . . .12$
Ft In.

0

0

0

Reference section of the Eagle Sandstone, measured on the north side of Miner Creek in the NW1/4 sec. 26, T. 2 S., R. 8 E., Park County, Mont.-Continued

Eagle Sandstone (Upper Cretaceous)-Continued

33. Siltstone, platy, greenish-gray $(5 G \dot{Y} \overline{6} / 1)$, sandy. Contains disseminated plant fragments. Weathers to yellowish gray (5Y 8/1) _...............................

32. Coal (Maxey coal bed or locally the Cokedale No. 2 bed)

Siltstone, very carbonaceous, with $F t$ coaly streaks (almost bone) ...... 1

Siltstone, very carbonaceous, approaches character of coal bed. Many tuffaceous siltstone partings_ $\quad 5$

31. Sandstone, platy, carbonaceous, light-olivegray (5Y 5/1), very calcareous, silty, very fine grained, arkosic. Weathers to grayish-yellow (5 $Y \quad 7 / 4)$ slabs $1 / 2-2$ in. thick. Few plant fragments. Attitude N. $89^{\circ}$ W., $35^{\circ}$ NE_..................

30. Sandstone, very massive (cliff former directly opposite Miner Creek junction), light-gray ( $N 7)$, fine-grained, crossbedded, arkosic. Good heavy-mineral suite. Calcareous. Massive spheroidal weathering. Weathers to grayish yellow ( $5 Y$ 7/4). Unit lenses out eastward and westward and does not occur behind the coke ovens. Large plant fragments (some several feet across) and several beds of oysters near middle of unit on east side. Many intraformational breccias about 1-2 ft thick

29. Siltstone, platy, carbonaceous, sandy; calcareous concretions $<3$ in. diameter, dark yellowish brown (10YR 4/2), moderate yellowish brown (10YR 5/4). Carbonized plant fragments. Poorly exposed. Immediately east of section this unit becomes very carbonaceous (almost characteristic of coal bed)

28. Sandstone, massive to thin-bedded, lightolive-gray (5Y 6/1), very fine grained, indurated, calcareous, slightly carbonaceous. Contains heavy-mineral suite. In places, resembles brackish-water deposition. Weathers to yellowish gray (5Y $8 / 1$. Unit thins abruptly eastward. Contains leaf impressions. A few vertical worm tubes

27. Siltstone, massive, greenish-gray $(5 G Y 6 / 1)$; poorly exposed......................

26. Siltstone, very carbonaceous, with coaly streaks.............................

25. Siltstone, massive, dark-greenish-gray ( $5 G Y$ $4 / 1$ ). Contains disseminated plant fragments. Limonitic concretions noted. Weathers to light olive gray $(5 Y 6 / 1) \ldots$

24. Siltstone, bone, and streaks of coal, very carbonaceous. Many carbonaceous, tuffaceous, sandy siltstone partings (as much as 3 in. thick, generally $<2$ in.). Just east of section the unit is cut out by a fault. Behind the coke ovens this unit is

$\begin{array}{ll}5 & 0 \\ 1 & 0 \\ & \\ & \\ 5 & 7\end{array}$


Reference section of the Eagle Sandstone, measured on the north side of Miner Creek in the NW1/4 sec. 26, T. 2 S., R. 8 E., Park County, Mont.-Continued

\section{Eagle Sandstone (Upper Cretaceous) - Continued} approximately the same thickness. Much of the adjustment during the orogeny of folding and thrusting was taken up in the coal and siltstone beds, which display considerable shearing and many tight folds that do not occur in overlying and underlying resistant sandstones. There are undoubtedly many bedding-plane faults as indicated by bedding-plane shears. Many partings now have a boudinagelike structure. Some carbonaceous siltstone beds contain macerated plant fragments. This unit correlates with the Big Dirty coal bed or, locally, the Cokedale No. 1

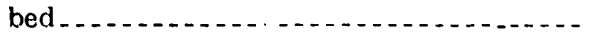

Total Eagle Sandstone above Virgelle Member

Virgelle Sandstone Member:

23. Sandstone, massive, indurated (cliff former), generally noncalcareous, very light gray $(N 8)$, fine-grained, arkosic. Although very massive, bedding can be delineated by dark $1 / 8-1 / 10-i n$. bands of heavy minerals. Unit is almost entirely crossbedded. Crossbedding is generally 2-3 ft long, or less, and generally truncated. Massive spheroidal weathering. Weathers to yellowish gray $(5 Y 7 / 2)$. Contains a few channel-fill deposits of pebbles and cobbles of siltstone.

22. Sandstone, medium-bedded, fine-grained, light-olive-gray ( $5 Y 5 / 2)$, calcareous, arkosic. Weathers to moderate yellowish brown $(10 Y R$ 5/4) .......................

21. Sandstone, medium-bedded, very poorly sorted, olive-gray $(5 Y 4 / 1)$, fine- to medium-grained, noncalcareous; derived from volcanic rock. Bottom 5 in. is olive-black (5Y 2/1) tuffaceous siltstone. Entire unit contains many small channel-fill deposits of silt and sand

20. Sandstone, massive, generally noncalcareous, very light gray (N8), fine-grained, arkosic. Less indurated than overlying units .....

19. Sandstone, massive, indurated, generally noncalcareous, very light gray $(N 8)$, finegrained, arkosic. Siltstone-pebble conglomerate generally at base............

18. Sandstone, thin-bedded $(1 / 2-4$ in. thick $)$, indurated, calcareous, greenish-gray ( $5 G Y$ $6 / 1$ ), very fine grained, arkosic. Weathers to olive gray $(5 Y 4 / 1)$. Has 2 -in. siltstone both in middle and at base of unit...

17. Sandstone, medium-bedded, calcareous, very light gray $(N 8)$, fine- to medium-grained, arkosic. Contains abundant heavy-mineral suite. Many small channel-fill deposits of siltstone pebbles. Bed is irregular in thickness and generally crossbedded.
Reference section of the Eagle Sandstone, measured on the north side of Miner Creek in the NW1/4 sec. 26, T. \& S., R. 8 E., Park County, Mont.-Continued

Eagle Sandstone (Upper Cretaceous) - Continued Virgelle Sandstone Member-Continued Ft In. Angular to subrounded grains. Sorting, fair. Weathers to yellowish gray $(5 Y 7 / 2)$

16. Sandstone, medium-bedded, indurated, calcareous, greenish-gray ( $5 G Y 6 / 1)$, very fine grained, arkosic. Weathers to olive

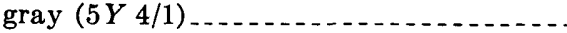

15. Sandstone, medium-bedded, very light gray, fine-grained, arkosic. Contains calcareous pods or lenses. Crossbedded. A few plant fragments. Contains heavy-mineral suite. Poorly sorted; some small channelfill deposits of coarse-grained sandstone ...

14. Sandstone, poorly sorted, very fine grained, dark-greenish-gray $(5 G Y 4 / 1)$, noncalcareous, andesitic. Crossbedded. Weathers to light olive gray ( $5 Y 5 / 2)$

13. Siltstone, thin-bedded, olive-gray $(5 Y 4 / 1)$. Weathers to light olive gray ( $5 Y 5 / 2$ ). Contains disseminated plant fragments ...

12. Sandstone, massive, very poorly sorted, coarse-grained, pale-olive $(10 Y$ 6/2) Weathers to yellowish gray $(5 Y 7 / 2)$. Contains sporadic pebbles of siltstone. Contains 4-in. olive-gray siltstone bed in middle of unit.

11. Sandstone, medium-bedded, indurated, calcareous, fine-grained, pale-olive $(10 Y 6 / 2)$. Weathers to yellowish gray $(5 Y 7 / 2) \ldots \ldots$

10. Sandstone, thick-bedded, very light gray, fine-grained, arkosic..................

9. Transition to overlying sandstone. ........

8. Sandstone, indurated, olive-gray (5Y 4/1), very fine grained, andesitic. Weathers to dark yellowish brown (10YR 4/2). Non-

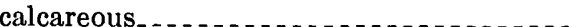

7. Transition from underlying sandstone..... -

6. Sandstone, massive, very light gray, finegrained, arkosic . . . . . . . .

5. Sandstone, medium-bedded, poorly sorted, very fine grained, andesitic, dusky-yellowgreen $(5 G Y 5 / 2)$. Weathers to moderate yellowish brown $(10 Y R$ 5/4) ...........

4. Sandstone, medium-bedded, poorly sorted, medium- to coarse-grained, very light gray (N8), arkosic, crossbedded. Weathers to yellowish gray $(5 Y 7 / 2) \ldots \ldots \ldots . .$.

3. Sandstone, medium-bedded, very light gray, fine-grained, arkosic

2. Sandstone, platy, very light gray $(N 8)$, indurated, calcareous, fine-grained, arkosic, with thin ( 2 in. or less) stringers of coarsegrained sandstone. Crossbedded in part. Weathers to olive gray $(5 Y 4 / 1) \ldots . . .$.

1. Sandstone, massive, very light gray $(N 8)$, fine-grained, arkosic, slightly calcareous, crossbedded. Contains quartz, orthoclase, andesine, heavy minerals, and fragments of andesite. Contains many vertical worm(?) tubes. Cliff-former. 4-ft zone of very poorly sorted sandstone containing silt 
Reference section of the Eagle Sandstone, measured on the north side of Miner Creek in the NW1/4 sec. 26, T. 2 S., R. 8 E., Park County, Mont.-Continued

Eagle Sandstone (Upper Cretaceous)-Continued $\quad F t \quad I n$. Virgelle Sandstone Member-Continued

that gives rock a mottled appearance 4 ft from top of unit. Massive spheroidal weathering. Angular to subrounded grains. Sorting, fair. Weathers to yellowish gray $(5 Y 7 / 2)$

Total thickness of Virgelle Sandstone Member. ............

Total thickness of Eagle Sandstone _. _ $\overline{\overline{645}}$

Telegraph Creek Formation.

\section{SECTION 15}

Composite section of the Eagle Sandstone, measured on west side of the Yellowstone River in the NE1/4 sec. 27, T. 2 S., R. 9 E., and adjusted with section of the Deerfield Oil Corp. Strong 1 well in SW11/4 sec. 11, T. 2 S., R. 9 E., Park County, Mont.

$$
\text { [Measured by Albert E. Roberts in 1961] }
$$

Cokedale Formation (Upper Cretaceous)

Eagle Sandstone (Upper Cretaceous):

28. Sandstone, medium-bedded, feldspathic, micaceous, fine- to medium-grained, lightolive-gray; rounded to subrounded grains; contains heavy-mineral suite and chert grains

27. Siltstone, thin- to medium-bedded, carbonaceous, olive-gray; thin interbedded coal beds (correlates with Cokedale coal bed) . -

26. Sandstone, medium- to thick-bedded, calcareous, micaceous, volcanic rock fragments, dusky-yellow-green; transition of Eagle Sandstone and Livingston Group lithologies; angular grains. Thin coal bed near middle of unit (correlates with Paddy Miles coal bed)

25. Shale, massive, silty, pyritic, pale-olive

24. Sandstone, thick-bedded, calcareous, very fine grained to fine-grained, yellow-green; angular grains

23. Siltstone, thin-bedded, olive-gray; thin interbedded olive-gray shale

22. Shale, thin-bedded, sandy, carbonaceous, gray; contains abundant orange (heulandite(?)) specks

Ft in

(and andstone, medium-bedded, calcareous, micaceous, pyritic, medium- to coarse-grained, very light gray; contains heavy-mineral suite

20. Shale, massive, silty, pyritic, olive-gray ....

19. Sandstone, medium-bedded, silty, calcareous, micaceous, very fine grained, light-gray; contains heavy-mineral suite.............

18. Shale, massive, sandy, olive-gray; contains abundant orange (heulandite(?)) specks; thin interbedded olive-gray siltstone ......

17. Sandstone, thick-bedded, calcareous, micaceous, medium- to coarse-grained, very light gray; contains heavy-mineral suite...-
Composite section of the Eagle Sandstone, measured on west side of the Yellowstone River in the NE1/4 sec. 27, T. 2 S., R. 9 E., and adjusted with section of the Deerfield Oil Corp. Strong 1 well in SW1/4 sec. 11, T. 2 S., R. 9 E., Park County, Mont.-Continued

Eagle Sandstone (Upper Cretaceous)—Continued $\quad$ Ft $\quad$ In.

16. Sandstone, thin- to medium-bedded, silty, calcareous, micaceous, very fine grained to fine-grained, very light gray; contains heavy-mineral suite....................

15. Sandstone, thin-bedded, silty, calcareous, micaceous, very fine grained to mediumgrained, light-olive-gray; thin interbedded siltstone and shale . . . . . . . . . . . . . . . .

14. Sandstone, thick-bedded, calcareous, micaceous, pyritic, fine- to coarse-grained, lightgray; contains orange (heulandite(?)) specks; contains heavy-mineral suite; angular grains . . . . . . . . . . . . . . . . . . . . .

13. Sandstone, thin-bedded, silty, calcareous, very fine grained to fine-grained, lightolive-gray; thin interbedded siltstone and

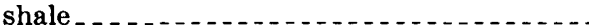

12. Sandstone, thick-bedded, calcareous, micaceous, very fine grained to fine-grained, light-olive-gray; thin interbedded siltstone _..............................

11. Shale, massive, sandy, pyritic, light-gray; contains orange (heulandite(?)) specks and thin interbedded siltstone . . . . . . . . ....

10. Siltstone, thin-bedded, sandy, micaceous, medium-dark-gray ; thin interbedded shale -

9. Shale, massive, silty, micaceous, olive-gray - -

8. Sandstone, thick-bedded, calcareous, very fine grained to coarse-grained, light-gray; predominantly quartz grains; rounded to subangular grains. . ....................

7. Sandstone, thin-bedded, silty, calcareous, very fine grained to fine-grained, light-gray; contains orange (heulandite(?)) specks . . . ...

6. Shale, massive, sandy, pyritic, medium-gray to olive-gray with orange (heulandite(?)) specks.............................

5. Sandstone, massive, arkosic, medium- to coarse-grained, light-olive-gray (5Y 6/1); interbedded silty very fine grained sandstone and carbonaceous siltstone in the lower $10 \mathrm{ft} \ldots \ldots$. . . . . . . . . . . . . . . . .

4. Coal (Big Dirty coal bed-measured at caved portal of Williams mine)

100

Bone . . . . . . . . . . . . . . . 1

Coal

Bony coal . . . . . . . . .

Siltstone, carbonaceous, sandy _...... 3

Siltstone, very carbonaceous......... 3

Coal_........................ 2

Sandstone, fine-grained, arkosic _..... 2

Siltstone, carbonaceous . . . . . . . . . 12

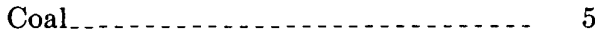

Bone . . . . . . . . . . . . . . . 1

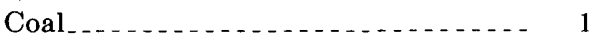

Siltstone, carbonaceous............. 12

Sandstone, fine-grained, arkosic _. . . _ 9

Siltstone, very carbonaceous.......... 3

Coal_... . . . . . . . . . . . . . . 21
$28 \quad 0$

170 
Composite section of the Eagle Sandstone, measured on west side of the Yellowstone River in the NEY4 sec. 27, T. 2 S., R. 9 E., and SW14 sec. 11, T. 2 S., R. 9 E., Park County, Mont.-Continued

Eagle Sandstone (Upper Cretaceous)-Continued Ft $\quad$ In. Sandstone, very fine grained........... 2

Coal

Siltstone, very carbonaceous; stringers of

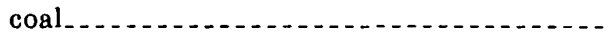

Sandstone, very fine grained, arkosic .......

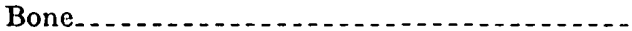

Sandstone, very fine grained. . . . . . . . .

Siltstone, carbonaceous ......

Coal .... . . .

Siltstone, carbonaceous

Coal _. . . . . . . . . . .

Sandstone, very fine grained . . . . . . . .

Bone..............

Bony coal.

Coal.

2

2

16

10

3

2

4

20

3

1

3

4

10

Siltstone, very carbonaceous . . . . . .

Total Eagle Sandstone above Virgelle Member................................

- 4960

Virgelle Sandstone Member:

3. Sandstone, massive, indurated, calcareous, light-gray ( $N 7$ ), fine- to medium-grained, arkosic; weathers to grayish yellow (5Y 7/4) . . . . . . . . . . .

2. Siltstone, micaceous, carbonaceous; interbedded fine- to medium-grained sandstone.

1. Sandistone, massive, indurated, light-gray $(N 7)$, fine-grained, arkosic. Contains heavy-mineral suite. Weathers to yellowish gray $(5 Y 7 / 2)$.

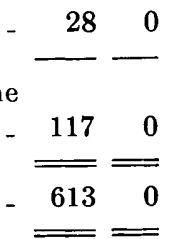

Telegraph Creek Formation.

Total thickness of Virgelle Sandstone

Member. ............................

Total thickness of Eagle Sandstone.... $\overline{\overline{613}}=$

620

$27 \quad 0$

(2)

28 adjusted with section of the Deerfield Oil Corp. Strong 1 well in

\section{$T y$}

Type section - of the Cokedale Formation of the Livingston Group measured in the $S 1 / 2$ sec. 29 and the $N E Y_{4}^{1}$ sec. 26, T. $2 S ., R$ 8 E., Park County, Munt.-Continued

Upper Cretaceous-Livingston Group-Cokedale Formation:

186. Siltstone, thick-bedded, tuffaceous, olive-

184. Covered interval-probably siltstone, light-

181. Sandstone, volcanic, massive, crossbedded,

\section{COKEDALE FORMATION}

Stratigraphic section 16 of the Cokedale Formation of the Livingston Group, measured at the abandoned townsite of Cokedale, Mont. (sections 1 and 2, fig. 15), is the type section of the formation.

\section{SECTION 16}

Type section of the Cokedale Formation of the Livingston Group, measured in the $S 1 / 2$ sec. 23 and the NE1/4 sec. 26, T. 2 S., R. 8 E., Park County, Mont.

[Measured by A. E. Roberts and A. L. Benson, 1961]

Upper Cretaceous-Livingston Group-Miner Creek Formation. gray $(5 Y 3 / 2)$; weathers to light olive gray $(5 Y 5 / 2) \ldots$

185. Sandstone, volcanic, thin- to mediumbedded, fine-grained, andesitic, calcareous, olive-gray $(5 Y 3 / 2)$; weathers to light olive gray $(5 Y 5 / 2)$ olive-gray . . . . . . . . . .

183. Sandstone, volcanic, massive, crossbedded, fine- to coarse-grained, poorly sorted, andesitic, light-olive-gray ( $5 Y \quad 5 / 2)$; weathers to pale yellowish brown (10YR 6/2) ; ridge former. . . . . . . . . .

182. Siltstone, thick-bedded, tuffaceous, lightolive-gray $(5 Y 5 / 2)$; weathers to yellowish gray $(5 Y 7 / 2) \ldots \ldots$ fine- to medium-grained, andesitic, indurated, greenish-gray (5GY 6/1); weathers to light olive gray (5Y 6/1); ridge former......................

180. Siltstone, medium-bedded, tuffaceous, lightolive-gray $(5 Y 5 / 2)$; weatbers to yellowish gray $(5 Y 7 / 2) \ldots \ldots$

179. Sandstone, volcanic, massive, very fine grained, silty, andesitic, olive-gray ( $5 Y$ $4 / 1$ ); weathers to light olive gray ( $5 Y$

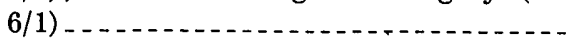

178. Sandstone, volcanic, thin-bedded, crossbedded, fine-grained, andesitic;indurated, light-olive-gray (5Y 5/2); has banded character imparted by thin (less than $1 / 8$ in.) layers of ferromagnesian minerals on bedding planes; weathers to yellowish gray $(5 Y 7 / 2)$; ridge former.........

177. Siltstone, massive, tuffaceous, grayish-olive $(10 Y 4 / 2)$; weathers to greenish gray (5GY 6/1)

Ft In

34

22

206

75

$5 \quad 9$

$\begin{array}{ll}7 & 8\end{array}$

29

80

$17 \quad 10$

176. Sandstone, volcanic, massive, fine-grained, andesitic, indurated, light-olive-gray ( $5 Y$ $5 / 2$ ) ; has pronounced crossbedding; contains bronze-colored biotite; has banded character imparted by thin (less than $0.25 \mathrm{in}$.) layers of ferromagnesian minerals on bedding planes; weathers to yellowish gray $(5 Y 7 / 2)$; ridge former ..-

175. Siltstone, medium-bedded, tuffaceous, olivegray $(5 Y 2 / 2)$; weathers to yellowish gray $(5 Y 7 / 2) \ldots$

174. Sandstone, volcanic, thin-bedded, finegrained, andesitic, light-olive-gray (5Y $5 / 2)$; weathers to yellowish gray (5Y $7 / 2)$ -

173. Siltstone, thick-bedded, tuffaceous, olivegray ( $5 Y 3 / 2)$; weathers to yellowish gray $(5 Y 7 / 2) \ldots \ldots$
66

15

12

$2 \quad 3$ 


\section{SECTION 16-Continued}

Type section of the Cokedale Formation of the Livingston Group, measured in the $S \frac{1}{2}$ sec. 23 and the NE1/4 sec. 26, T. 2 S., R. 8 E., Park County, Mont.-Continued

Upper Cretaceous-Livingston Group-Cokedale Formation-Continued

172. Sandstone, volcanic, medium-bedded, finegrained, andesitic, light-olive-gray (5Y $5 / 2)$; weathers to yellowish gray $(5 Y 7 / 2)$ -

171. Covered interval - probably siltstone, olivegray

170. Sandstone, volcanic, thin-bedded, finegrained, andesitic light-olive-gray (5Y $5 / 2)$; weathers to yellowish gray $(5 Y 7 / 2)$

169. Covered interval-probably siltstone, olivegray _................................

168. Sandstone, volcanic, massive, fine- to medium-grained, poorly sorted, andesitic, indurated, light-olive-gray $\left(\begin{array}{ll}5 Y & 5 / 2\end{array}\right)$; weathers to yellowish gray $(5 Y 7 / 2)$; ridge former .......................

167. Siltstone, massive, tuffaceous, olive-gray $(5 Y 3 / 2)$; weathers to yellowish gray ( $5 Y$ $7 / 2)$; contains fresh-water gastropods; USGS Mesozoic loc. 28593 . . . . . . .

166. Sandstone, volcanic, massive, crossbedded, fine-grained, andesitic, indurated, duskyyellow-green $(5 G Y \quad 5 / 2)$; weathers to yellowish gray $(5 Y 7 / 2)$; slight tendency to form ridges...................

165. Siltstone, massive, tuffaceous, light-olivegray $(5 Y 5 / 2)$; weathers to yellowish gray $(5 Y 7 / 2)$; contains heulandite $\ldots . . . .$.

164. Sandstone, volcanic, thin- to mediumbedded, fine- to medium-grained, poorly sorted, andesitic dusky-yellow-green $(5 G Y 5 / 2)$; weathers to moderate yellowish brown $(10 Y R 5 / 4)$; ridge former ....

163. Siltstone, massive, tuffaceous, olive-gray $\left(\begin{array}{ll}5 Y & 3 / 2\end{array}\right)$; weathers to yellowish gray (5Y 7/2); poorly exposed..............

162. Sandstone, volcanic, medium-bedded, finegrained, andesitic, dusky-yellow-green (5GY 6/2); weathers to pale yellowish brown $(10 Y R 5 / 2)$

161. Covered interval-probably siltstone, olive-

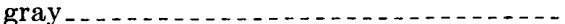

160. Sandstone, volcanic, thin- to mediumbedded, fine-grained, andesitic, lightolive-gray (5Y 5/2), weathers to pale yellowish brown (10YR 6/2); top bed of of prominent ridge-forming sandstone unit. . . . . . . . .

159. Sandstone, volcanic, thin-bedded, finegrained, silty, clayey, andesitic, darkgreenish-gray ( $5 G 4 / 1)$; contains red specks of heulandite; weathers to yellowish gray $(5 Y 7 / 2)$

158. Sandstone, volcanic, thin- to thick-bedded, fine-grained, andesitic, dusky-yellowgreen $(5 G Y 5 / 2)$; contains some clay lenses or layers, generally less than 3 in. thick; weathers to light olive gray ( $5 Y$ $5 / 2)$; ridge former
SECTION 16-Continued

Type section of the Cokedale Formation of the Livingston Group measured in the $S_{1 / 2}^{1 / 2}$ sec. 23 and the $N E 1 / 4$ sec. 26, T. $2 S ., R$. 8 E., Park County, Mont.-Continued

Upper Cretaceous-Livingston Group-Cokedale Formation-Continued

157. Siltstone, medium-bedded, olive-gray $(5 Y$ $3 / 2)$; weathers to light olive gray ( $5 Y$ $5 / 2)$

156. Sandstone, volcanic, conglomeratic, massive, fine- to coarse-grained, very poorly sorted, andesitic, light-olive-gray (5Y $5 / 2)$; contains pebbles of volcanic rock and mudstone; weathers to pale yellowish

155. Siltstone, thick-bedded, olive-gray $(5 Y 3 / 2)$

154. Sandstone, volcanic, conglomeratic, thickrock and mudstone and not abundant;

153. Siltstone, medium-bedded, olive-gray ( $5 Y$ $3 / 2$ ); weathers to light olive gray ( $5 Y$

151. Siltstone, thick-bedded, olive-gray $(5 Y 3 / 2)$;

150. Sandstone, volcanic, thick-bedded, fine-

145. Sandstone, volcanic, medium-bedded, crossbrown $(10 Y R 6 / 2)$; ridge former ........ weathers to light olive-gray $(5 Y 5 / 2) \ldots$ bedded, fine- to coarse-grained, very poorly sorted, andesitic, light-olive-gray (5Y 5/2); pebbles are small (as much as 1 in. in longest dimension but generally less than $0.25 \mathrm{in}$.), composed of volcanic weathers to pale yellowish brown (10YR $6 / 2)$; ridge former . . . . . . . . . . . . . . $5 / 2) \ldots \ldots \ldots$ fine grained, silty, andesitic, indurated, light-olive-gray $\left(\begin{array}{lll}5 Y & 5 / 2\end{array}\right)$; weathers to light olive gray ( $5 Y 6 / 1)$; contains macerated plant fragments . . . . . . . . . . . . weathers to light olive gray $(5 Y 5 / 2) \ldots$ grained, andesitic, light-olive-gray $(5 Y$ $5 / 2)$; weathers to yellowish gray $(5 Y 7 / 2)$; very slight ridge former.............. ndstone, volcanic, thick-bedded, very fine grained, silty, andesitic, olive-gray (5Y 4/1); weathers to light olive gray $(5 Y 6 / 1)$ bedded, fine-grained, andesitic, lightolive-gxay ( $5 Y 6 / 1)$; has banded character imparted by thin (less than $1 / 16$ in.)

Ft In. layers of ferromagnesian minerals on 


\section{SECTION 16-Continued}

Type section of the Cokedale Formation of the Livingston Group, measured in the $S 32$ sec. 23 and the NE'H sec. 26, T. $2 S ., R$. 8 E., Park County, Mont.-Continued

Upper Cretaceous-Livingston Group-Cokedale Formation-Continued

bedding planes; weathers to pale yellowish brown $(10 Y R 6 / 2) \ldots$

144. Sandstone, volcanic, massive, very fine grained, silty, andesitic, olive-gray ( $5 Y$ $4 / 1)$; weathers to light olive gray ( $5 Y$ $6 / 1)$

143. Sandstone, volcanic, medium- to thickbedded, fine-grained, andesitic, duskyyellow-green $(5 G Y 5 / 2)$; weathers to pale yellowish brown $(10 Y R \quad 6 / 2)$; ridge former

142. Siltstone, massive, tuffaceous, olive-green $(5 Y 5 / 2)$; weathers to yellowish gray (5Y 7/2) . . . . . . . . .

141. Sandstone, volcanic, medium-bedded to massive, crossbedded, fine-grained, andesitic, dusky-yellow-green ( $5 G Y \quad 5 / 2)$; weathers to pale, yellowish brown (10 $Y R 6 / 2$ ) ; very prominent ridge former.

140. Siltstone, volcanic, medium-bedded to massive, crossbedded, fine-grained, andesitic, dusky-yellow-green ( $5 G Y \quad 5 / 2)$; weathers to pale yellowish brown (10YR $6 / 2$ ); very prominent ridge former......

139. Sandstone, volcanic, thick-bedded, finegrained, andesitic, indurated, mediumlight-gray ( $N 6)$; has banded character imparted by thin (less than $1 / 16$ in.) layers of ferromagnesian minerals on bedding planes; weathers to light olive gray ( $5 Y 6 / 1)$; slight ridge former.......

138. Siltstone, massive, tuffaceous, olive-gray ( $5 Y 4 / 1)$; weathers to light olive gray (5Y6/1) ............................

137. Sandstone, volcanic, medium-bedded, finegrained, andesitic, slightly indurated, medium-light-gray (N6); has banded character imparted by thin (less than $1 / 10$ in.) layers of ferromagnesian minerals on bedding planes; weathers to light olive gray $(5 Y 6 / 1) \ldots \ldots$

136. Siltstone, massive, tuffaceous, clayey, olivegray ( $5 Y 4 / 1)$; weathers to light olive gray $(5 Y 6 / 1) \ldots \ldots$

135. Sandstone, volcanic, medium- to thickbedded, fine-grained, andesitic, slightly indurated in the lower half, greenish-gray ( $5 G Y 6 / 1)$; weathers to yellowish gray (5Y 7/2) and light olive gray (5Y 6/1); contains a few plant fragments........

134. Siltstone, massive, tuffaceous, olive-gray (5Y 4/1); weathers to light olive gray (5Y 6/1) . . . . . . . . . .

133. Sandstone, volcanic, conglomeratic, massive, fine-.. to coarse-grained, clayey, poorly sorted, andesitic, olive-gray ( $5 Y$ $4 / 1)$; wenthers to dark yellowish brown (10YR 4/2); pebbles and cobbles are andesite; slight tendency to form ridges.-
SECTION 16-Continued

Type section of the Cokedale Formation of the Livingston Group measured in the $S 16$ sec. 23 and the NEY4 sec. 26, T. $2 S ., R$. 8 E., Park County, Mont.-Continued

Upper Cretaceous-Livingston Group-Cokedale Formation-Continued

132. Siltstone, massive, tuffaceous, olive-gray (5Y 4/1); weathers to light olive gray $(5 Y 6 / 1)$; a 2 -ft-thick zone in the middle of the unit and a 6-in.-thick zone $1 \mathrm{ft}$ from the base of the unit are wellindurated..............................
215

43

$8 \quad 0$

13

8
131. Sandstone, volcanic, medium- to thickbedded, very fine grained, silty, andesitic, medium-gray ( $N 5$ ); weathers to pale yellowish brown (10YR 6/2); slight tendency to form ridges............

130. Siltstone, massive, tuffaceous, olive-gray ( $5 Y 4 / 1)$; weathers to light olive gray ( $5 Y$ $6 / 1)$

129. Sandstone, volcanic, medium-bedded, finegrained, andesitic, well-indurated in lower 7 in., dusky-yellow-green ( $5 G Y$ $5 / 2)$; weathers to pale yellowish brown (10YR 6/2)

128. Siltstone, massive, tuffaceous, olive-gray ( $5 Y$ 4/1); weathers to light olive gray $(5 Y 6 / 1)$

127. Sandstone, volcanic, thick-bedded, very fine grained, andesitic, yellowish-gray ( $5 Y 7 / 2)$; weathers to light olive gray ( $5 Y 6 / 1)$; slight tendency to form ridges .

126. Siltstone, massive, tuffaceous, olive-gray ( $5 Y$ 4/1); weathers to light olive gray $(5 Y 6 / 1)$

34

125. Sandstone, volcanic, massive, fine-grained, andesitic, yellowish-gray $\left(\begin{array}{ll}5 Y & 7 / 2\end{array}\right)$; weathers to light olive gray ( $5 Y 6 / 1)$; prominent ridge former. .............

124. Siltstone, massive, clayey, olive-gray ( $5 Y$ $4 / 1$ ); weathers to light olive gray ( $5 Y$ 6/1) _................................

123. Sandstone, volcanic, massive, crossbedded, medium- to coarse-grained; contains some granule-size grains of mudstone on some bedding planes; poorly sorted; andesitic; dusky-yellow-green ( $5 G Y 5 / 2)$; weathers to dark yellowish brown (10YR $4 / 2)$; contains a 6 -in.-thick well-indurated zone at top of unit. ..................

122. Sandstone, volcanic, thin-bedded, finegrained, well-indurated, andesitic, olivegray ( $5 Y 4 / 1)$; weathers to brownish gray ( $5 Y R 4 / 1)$

121. Siltstone, massive, clayey, olive-gray ( $5 Y$ $4 / 1$ ); weathers to light olive gray ( $5 Y$ 6/1) . . . . .

120. Sandstone, volcanic, conglomeratic, thinto medium-bedded, crossbedded, fineto medium-grained, andesitic, olive-gray ( $5 Y 4 / 1)$; pebbles are in lowest 28 in. of unit and are of volcanic rocks, quartzite, and chert; weathers to dark yellowish brown (10YR 4/2); ridge former........ 


\section{SECTION 16-Continned}

Type section of the Cokedale Formation of the Livingston Group, measured in the $S 12$ sec. 23 and the $N E 1 / 4$ sec. 26, T. $2 S ., R$. 8 E., Park County, Mont.-Continued

Upper Cretaceous-Livingston Group-Cokedale Formation-Continued

119. Siltstone, massive, olive-gray ( $5 Y \quad 4 / 1)$; weathers to light olive gray ( $5 Y 6 / 1)$; contains a 4-ft.-thick lens of fine-grained sandstone $1 \mathrm{ft}$ from base

118. Sandstone, volcanic, thin- to thick-bedded, crossbedded, fine-grained, andesitic, dark-greenish-gray ( $5 G Y 4 / 1$ ); weathers to dark yellowish brown; ridge former . -

117. Siltstone, massive, light-olive-gray ( $5 Y 5 / 2)$; weathers to dusky yellow ( $5 Y 6 / 4)$; poorly exposed

116. Sandstone, volcanic, medium-bedded, very fine to fine-grained, andesitic, wellindurated, medium-gray ( $N 5)$; weathers to pale yellowish brown (10YR 6/2) ... -

115. Sandstone, volcanic, thin- to thick-bedded, crossbedded, fine-grained, andesitic, poorly indurated, medium-gray $(N 5)$; weathers to pale yellowish brown ( $10 Y R$ $6 / 2)$

114. Sandstone, volcanic, thin- to thick-bedded, crossbedded, fine-grained, andesitic, medium-gray (N5); contains a few scourand-fill deposits that bear mudstone pebbles as much as 1 in. in longest dimension; weathers to pale yellowish brown $(10 Y R 6 / 2)$; slight tendency to form ridges

113. Siltstone, massive, clayey, olive-gray ( $5 Y$ $4 / 1$ ); weathers to light olive gray (5Y $6 / 1)$

112. Sandstone, volcanic, thin- to thick-bedded, crossbedded, fine- to medium-grained, andesitic, medium-gray (N5); weathers to olive gray (5Y 4/1); contains petrified wood and dinosaur bones; slight ridge former

111. Siltstone, massive, tuffaceous, dusky-yellow-green $(5 G Y 5 / 2)$; weathers to light olive gray $(5 Y 5 / 2)$

110. Bentonite, poorly exposed .........

109. Siltstone, massiye, tuffaceous, dusky-yellow-green ( $5 G Y 5 / 2)$; weathers to light olive gray $(5 Y 5 / 2)$

108. Sandstone, volcanic, thin-bedded, crossbedded, medium-grained, andesitic, dusky-yellow-green $(5 G Y 5 / 2)$; weathers to light olive gray $(5 Y \quad 5 / 2)$; contains dinosaur bones and petrified wood; ridge former

107. Siltstone, thick-bedded, well-indurated, dark-gray (N3); weathers to pale brown $(5 Y R 5 / 2)$; contains petrified wood and plant fragments; slight tendency to form ridges; USGS Paleobotany loc. D4120.

\section{SECTION 16-Continued}

Type section of the Cokedale Formation of the Livingston Group, measured in the $S_{1 / 2}^{1}$ sec. 23 and the NE1/4 sec. 26, T. $2 S$., $R$. 8 E., Park County, Mont.-Continued

Upper Cretaceous-Livingston Group-Cokedale Formation-Continued Ft. In.

106. Siltstone, thin-bedded, dusky-yellow-green $(5 G Y 5 / 2)$; weathers to light olive gray (5Y 5/2); contains macerated plant fragments; poorly exposed.

105. Sandstone, volcanic, thin- to mediumbedded, crossbedded, fine- to mediumgrained, andesitic, medium-gray (N5); weathers to light olive gray $(5 Y 6 / 1) \ldots$

104. Sandstone, volcanic, thin- to mediumbedded, fine-grained, clayey, poorly sorted, andesitic, dusky-yellow-green $(5 G Y 5 / 2)$; weathers to light olive gray (5Y 5/2); poorly exposed .............

103. Sandstone, volcanic, thin- to thick-bedded, medium- to coarse-grained, very poorly sorted, andesitic, grayish-olive-green (5GY 3/2); contains small-scale crossbedding; weathers to light olive gray ( $5 Y 6 / 1)$; slight tendency to form ridges.

102. Siltstone, thin-bedded, well-indurated, dark-gray ( $N 3)$; weathers to pale brown $(5 Y R 5 / 2)$ and light olive gray $(5 Y 6 / 1)$; contains plant fragments; USGS Paleobotany loc. D1815-2

101. Mudstone, massive, tuffaceous, silty, olivegray (5Y 4/1); weathers to light olive gray ( $5 Y 6 / 1)$; contains macerated plant fragments; poorly exposed; USGS Paleobotany loc. D1815-1.... . . . . . . . . . .

100. Sandstone, volcanic, medium- to thickbedded, fine to coarse grained, andesitic, very poorly sorted, medium-gray $(N 5)$, weathers to olive gray ( $5 Y 4 / 1)$; locally contains crossbedded and scour-and-fill deposits $0.5-1 \mathrm{ft}$. thick; contains petrified wood and some mudstone pebbles; slight tendency to form ridges..............

99. Siltstone, massive, olive-gray (5Y.4/1); weathers to light olive gray (5Y 6/1); very poorly exposed

98. Sandstone, volcanic, massive, crossbedded, medium- to coarse-grained, poorly sorted, andesitic, dusky-yellow-green ( $5 G Y 5 / 2)$; weathers to brownish black ( $5 Y R 2 / 1)$ or, less commonly, to moderate yellowish brown (10YR 5/4); contains many small channels filled with pebbles and granulesize sand composed of lithic fragments; contains petrified wood; ridge former ...

97. Tuff, medium-bedded, water-laid, yellowgreen $(5 G Y 6 / 2)$; weathers to yellowish gray (5Y 7/2); contains petrified wood; overlying unit has channeled into this unit. ....................................

96. Covered interval-probably water-laid tuff_ 


\section{SECTION 16-Continued}

Type section of the Cokedale Formation of the Livingston Group, measured in the $S_{12}^{1}$ sec. 23 and the $N E_{1 / 4}^{1 / 4}$ sec. 26, T. $2 S ., R$. 8 E., Park County, Mont.-Continued

Upper Cretaceous-Livingston. Group-Cokedale Formation-Continued

95. Sandstone, volcanic, medium-bedded, coarsegrained, very poorly sorted, andesitic, dusky-yellow-green ( $5 G Y 5 / 2)$; weathers to moderate yellowish brown $(10 Y R 5 / 4)$; contains pebbles and granule-size sand composed of lithic fragments . . . . . . . .

94. Tuff, medium-bedded, water-laid, yellowgreen ( $5 G Y 6 / 2)$; weathers to yellowish gray $(5 Y 7 / 2)$

93. Sandstone, volcanic, massive, crossbedded in part, coarse-grained, very poorly sorted andesitic, dusky-yellow-green (5GY 5/2); weathers slightly to moderate yellowish brown $(10 Y R 5 / 4$;) pebbles and granulesize sand composed of lithic fragments are rare to common; contains petrified wood ridge former

92. Sandstone, volcanic, conglomeratic, thickbedded, crossbedded, very coarse grained, andesitic, dusky-yellow-green ( $5 G Y 5 / 2)$; weathers to dusky yellow ( $5 Y 6 / 4)$; contains petrified wood. . . . .

91. Tuff, medium-bedded, well-indurated, waterlaid, olive-gray ( $5 Y 4 / 1)$; weathers to moderate yellowish brown (10YR 5/4); contains plant fragments . . . . . . . . .

90. Sandstone, volcanic, massive, fine- to coarsegrained, very poorly sorted, andesitic grayish-olive $(10 Y 4 / 2)$; pebbles and granules composed of lithic fragments are rare to plentiful: weathers to pale olive $(10 Y 6 / 2)$; recovered large fragments of leg bones from the dinosaur, Monoclonius, from this unit; poorly exposed..............................

89. Sandstone, medium-bedded, very fine grained, well-indurated, fairly well sorted, pale-grayish-green $(10 G 5 / 2)$; weathers to moderate yellowish brown (10YR 5/4); unit is transitional between underlying quartzose sands and overlying volcanic sands - - -

88. Covered interval-probably tuffaceous, finegrained sandstone similar to overlying unit, except nonindurated

87. Sandstone, quartzose, massive to thinbedded, fine-grained, fairly well sorted, well-indurated, light-olive-gray $(5 Y 6 / 1)$; weathers to yellowish gray $(5 Y 7 / 2)$; contains heavy-mineral suite; ridge former; units 87, 88, and 89 probably western equivalent to part of Parkman Sandstone.

86. Covered interval-probably tuffaceous siltstone, light-olive-gray $(5 Y 5 / 2) \ldots$

85. Sandstone, volcanic, thin- to mediumbedded, very fine grained, andesitic, wellindurated, calcareous, dark-greenish-gray $(5 G Y 4 / 1)$; weathers to pale brown $(5 Y R 5 / 2)$
SECTION 16-Continued

Type section of the Cokedale Formation of the Livingston Group, measured in the $S 1 / 2$ sec. 23 and the NE14 sec. 26, T. 2 S., $R$. 8 E., Park County, Mont.-Continued

Upper Cretaceous-Livingston Group-Cokedale Formation-Continued

Ft $\quad I n$

84. Mudstone, massive, olive-gray (5Y 4/1) weathers to light olive gray ( $5 Y 6 / 1)$; tuffaceous throughout; contains macerated plant fragments; USGS Paleobotany loc.
26

20

50

20

10

70 0

$\begin{array}{ll}7 & 0\end{array}$

80

$80 \quad 0$

6 D1611_...............................

83. Sandstone, volcanic, thin- to mediumbedded, very fine grained, andesitic, wellindurated, calcareous, dark-greenish-gray $(5 G Y 4 / 1)$; weathers to pale brown $(5 Y R$ $5 / 2) \ldots \ldots \ldots$

82. Sandstone, quartzose, thin-bedded to massive, crossbedded, fine-grained, fairly well sorted, resembles quartzose beds in the Eagle Sandstone; medium-light-gray $(N 6)$; weathers to yellowish gray $(5 Y 7 / 2)$ and white; contains heavy-mineral suite......

81. Tuff, bentonitic, pale-greenish-yellow ( $10 Y$ $8 / 2)$; weathers to yellowish gray $(5 Y 8 / 1)$.

80. Sandstone, volcanic, thin- to mediumbedded, very fine grained, andesitic, wellindurated, calcareous, dark-greenish-gray $(5 G Y 4 / 1)$; weathers to pale brown $(5 Y R$ $5 / 2)$

79. Claystone, thick-bedded, dark-greenish-gray $(5 G Y 4 / 1)$; weathers to greenish gray ( $5 G Y$ $6 / 1) \ldots \ldots \ldots$

78. Sandstone, volcanic, thin- to mediumbedded, very fine grained, andesitic, wellindurated, calcareous, dark-greenish-gray $(5 G Y 4 / 1)$; weathers to pale brown ( $5 Y R$ $5 / 2) \ldots$

77. Claystone, massive, dark-greenish-gray ( $5 G Y$ $4 / 1$ ); weathers to greenish gray ( $5 G Y 6 / 1)$.

76. Sandstone, volcanic, medium-bedded, very fine grained, andesitic, well-indurated, olive-gray $(5 Y 4 / 1)$; weathers to light olive gray (5Y 6/1); contains macerated plant fragments; USGS Paleobotany loc. D1610 -

75. Siltstone, massive, sandy, tuffaceous, clayey, dusky-yellow-green $(5 G Y 5 / 2)$; weathers to yellowish gray $(5 Y 7 / 2) \ldots$

74. Tuff, massive, bentonitic, pale-greenishyellow (10Y 8/2); weathers to yellowish gray $(5 Y 8 / 1) \ldots \ldots$

73. Sandstone, volcanic, massive, very fine grained, andesitic, tuffaceous, silty, clayey, dusky-yellow-green $(5 G Y 5 / 2)$; weathers to yellowish gray $(5 Y 7 / 2) \ldots$

72. Mudstone, massive, olive-gray ( $5 Y$ 4/1); weathers to light olive gray (5Y 6/1); carbonaceous in the upper part......

71. Sandstone, volcanic, thin- to thick-bedded, fine-grained, andesitic, well-indurated, medium-gray $(N 5)$; weathers to lightolive gray $(5 Y 6 / 1)$; contains petrified wood. 


\section{SECTION 16-Continued}

Type section of the Cokedale Formation of the Livingston Group, measured in the $S 1 / 2$ sec. 23 and the NE1/4 sec. 26, T. $2 S$., $R$. 8 E., Park County, Mont.-Continued

\section{Upper Cretaceous-Livingston Group-Cokedale} Formation-Continued

70. Siltstone, massive, very carbonaceous, olivegray ( $5 Y 4 / 1)$; weathers to light olive gray $(5 Y$ 6/1)

69. Sandstone, volcanic, thin- to thick-bedded, fine to coarse-grained, andesitic, wellindurated, grayish-olive-green ( $5 G Y 3 / 2)$; weathers to light olive gray $(5 Y 5 / 2)$; locally contains scour-and-fill channels that bear granules to small (as much as 1 in. in diameter) pebbles of volcanic rock and mudstone; contains thin beds of interbedded siltstone; contains petrified wood and plant fragments; ridge former......

68. Siltstone, thick-bedded, sanày, tuffaceous, dusky-yellow-green ( $5 G Y 5 / 2)$; weathers to yellowish gray $(5 Y 7 / 2) \ldots$

67. Sandstone, volcanic, medium-bedded, finegrained, andesitic, well-indurated, mediumgray $(N 4)$; weathers to light olive gray (5Y 5/2); contains petrified wood........

66. Siltstone, thick-bedded, sandy, mediumdark-gray (N4); weathers to light olive gray $(5 Y 6 / 1) \ldots$

65. Sandstone, volcanic, medium-bedded, finegrained, andesitic, well-indurated, medium-gray $(N 4)$; weathers to light olive gray $(5 Y 5 / 2)$; contains petrified wood...

64. Siltstone, massive, sandy, medium-darkgray $(N 4)$; weathers to light olive gray (5Y 6/1); locally slightly calcareous; contains abundant petrified wood-mostly palm trees-and some macerated plant fragments

63. Sandstone, volcanic, medium-bedded, finegrained, andesitic, well-indurated, medium-gray (N4); weathers to light olive gray $(5 Y 5 / 2)$; contains petrified wood...-

62. Siltstone, medium-bedded, sandy, mediumdark-gray (N4); weathers to light olive gray $(5 Y 6 / 1) \ldots$

61. Sandstone, volcanic, medium-bedded, finegrained, andesitic, well-indurated, medium-gray $(N 4)$; weathers to light olive gray $(5 Y 5 / 2)$; contains petrified wood...

60. Siltstone, thick-bedded, sandy, mediumdark-gray (N4); weathers to light olive

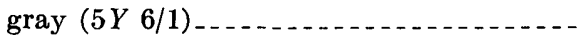

59. Sandstone, volcanic, medium-bedded, finegrained, andesitic, well-indurated, medium-gray (N4); weathers to light olive gray $(5 Y 5 / 2)$; contains petrified wood...

58. Sandstone, volcanic, thick-bedded, very fine grained, andesitic, silty, clayey, duskyyellow-green $(5 G Y 5 / 2)$; weathers to light olive gray ( $5 Y 6 / 1)$; contains macerated plant fragments.
$1 \quad 1$

25

16

(2)

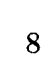

84

$3 \quad 9$

110

$5 \quad 5$

$2 \quad 1$

11

$2 \quad 11$

\section{SECTION 16-Continued}

Type section of the Cokedale Formation of the Livingston Group, measured in the $S 1 / 2$ sec. 23 and the $N E 1 / 4$ sec. 26, T. \& S., $R$. 8 E., Park County, Mont.-Continued

Upper Cretaceous-Livingston Group-Cokedale Formation-Continued
7. Sandstone, volcanic, medium-bedded, finegrained, andesitic, well-indurated, locally calcareous, light-olive-gray $(5 Y \quad 5 / 2)$; weathers to light olive gray $(5 Y 6 / 1)$; contains plant fragments and leaf prints....

56. Claystone, massive, very carbonaceous, dark-gray $(N 3)$; weathers to light olive gray (5Y 6/1); contains macerated plant fragments . . . . . . . . . . . . . . . . . . .

55. Sandstone, volcanic, medium- to thickbedded, crossbedded, fine- to coarsegrained and locally conglomeratic with pebbles of volcanic rock and mudstone as much as $0.75 \mathrm{in}$. in diameter, very poorly sorted, andesitic, medium-gray (N5); weathers to light gray (N7); grains angular to subangular; contains abundant feldspar and biotite; slightly calcareous; contains wood and plant fragments; ridge former

54. Claystone, thick-bedded, very carbonaceous, olive-gray $(5 Y 3 / 2)$; weathers to light olive gray $(5 Y 5 / 2) \ldots$

Ft In

59

$5 \quad 2$

$38 \quad 8$

35

53. Tuff, devitrified, greenish-gray ( $5 G Y 6 / 1)$; weathers to yellowish gray $(5 Y 7 / 2)$ to white; contains euhedral crystals of biotite and feldspar

52. Mudstone, massive, sandy, olive-gray (5Y $5 / 4)$; weathers to light olive gray ( $5 Y 6 / 1)$; contains abundant macerated plant fragments..............................

51. Siltstone, massive, clayey, olive-gray ( $5 Y$ $4 / 1$ ) ; contains rare red specks of heulandite: weathers to light olive gray $(5 Y 6 / 1)$.

50. Siltstone, thin- to medium-bedded, wellindurated, grayish-olive-green ( $5 G Y 3 / 2)$; weathers to grayish brown $(5 Y R 3 / 2) \ldots$

49. Sandstone, volcanic, thin-bedded to massive, fine- to coarse-grained but dominantly fine-grained, andesitic, calcareous, duskyyellow-green $(5 G Y \quad 5 / 2)$; weathers to grayish olive (10Y 4/2); locally contains scour-and-fill channels that bear granulesize grains; contains abundant petrified wood; ridge former ..................

48. Sandstone, volcanic, conglomeratic, thin- to medium-bedded, crossbedded, fine- to coarse-grained, very poorly sorted, andesitic, dusky-yellow-green $(5 G Y \quad 5 / 2)$; weathers to light olive gray (5Y $5 / 2)$; pebbles, from granule size to $1 \mathrm{in}$. in diameter, are composed of volcanic rock and mudstone; contains lenses of claygrayish-olive-green ( $5 G Y \quad 3 / 2)$; contains abundant.fossil wood, dominantly of palm trees, and plant fragments; grades into overlying sandstone. 


\section{SECTION 16-Continued}

Type section of the Cokedale Formation of the Livingston Group, measured in the $S 1 / 2$ sec. 23 and the $N E 1 / 4$ sec. 26, T. $2 S$., $K$. 8 E., Park County, Mont.-Continued

Upper Cretaceous-Livingston Group-Cokedale Formation-Continued

47. Sandstone, thin-bedded to massive, fine- to coarse-grained, feldspathic (dominantly plagioclase), medium-light-gray $(N 6)$; grains angular to subangular; locally contains calcareous lenses and stringers; weathers to yellowish gray $(5 Y 7 / 2)$; massive spheroidal weathering ..........

46. Claystone, thin-bedded, very carbonaceous, grayish-black (N2); weathers to medium gray (N5); contains macerated plant fragments..........................

45. Sandstone, volcanic, thin-bedded, fine- to medium-grained, tuffaceous, andesitic, dusky-yellow-green $(5 G Y 5 / 2)$; weathers to dusky yellow ( $5 Y 6 / 4)$; contains macerated plant fragments. ...................

44. Claystone, thin-bedded, very carbonaceous, grayish-black (N2); weathers to medium gray. (N5); contains macerated plant fragments . . . . - .

43. Sandstone, volcanic, thin-bedded, finegrained, tuffaceous, andesitic, duskyyellow-green ( $5 G Y 5 / 2$ ); weathers to dusky

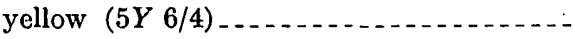

42. Claystone, thin-bedded, very carbonaceous, grayish-black (N2); weathers to medium gray (N5); contains macerated plant fragments.........................

41. Mudstone, thin-bedded, olive-gray (5Y 4/1); weathers to light olive gray $(5 Y 6 / 1)$

40. Bentonite, sandy, devitrified............

39. Mudstone, massive, olive-gray (5Y 4/1); weathers to light olive gray $(5 . Y 6 / 1)$....-

38. Sandstone, volcanic, thin-bedded, very fine grained, silty, bentonitic, andesitic, duskyyellow-green ( $5 G Y 5 / 2)$; weathers to dusky yellow $(5 Y 6 / 4)$

37. Claystone, medium-bedded, olive-gray ( $5 Y$ $4 / 1)$; weathers to light olive gray $(5 Y 6 / 1)$.

36. Sandstone, volcanic, thin-bedded, very fine grained, silty, bentonitic, andesitic, dusky-yellow-green ( $5 G Y 5 / 2)$; weathers to dusky yellow $(5 Y 6 / 4) \ldots$

35. Claystone, medium-bedded, olive-gray (5Y $4 / 1)$; weathers to light olive gray (5Y 6/1) .

34. Sandstone, voleanic, thin-bedded, finegrained, bentonitic, andesitic, duskyyellow-green ( $5 G Y 5 / 2)$; weathers to dusky yellow $(5 Y 6 / 4)$

33. Mudstone, massive, olive-gray (5Y 4/1); weathers to light olive gray $(5 Y 6 / 1)$

32. Sandstone, volcanic, thin-bedded to massive, fine- to medium-grained, poorly sorted, andesitic, carbonaceous,; dusky-yellowgreen ( $5 G Y 5 / 2)$; weathers to dusky yellow $(5 Y 6 / 4)$; contains macerated plant fragments. ........................

31. Coal, bony, dull, soft

\section{SECTION 16-Continued}

Type section of the Cokedale Formation of the Livingston Group, measured in the S1/2 sec. 23 and the NEY4 sec. 26, T. $2 S ., R$. 8 E., Park County, Mont.-Continued

Upper Cretaceous-Livingston Group-Cokedale Formation-Continued

30. Coal, blocky, bright, brown when cut, hard. Ft In.

29. Sandstone, volcanic, thin-bedded, very fine grained, silty, andesitic, dusky-yellowgreen $(5 G Y 5 / 2)$; weathers to dusky yellow $(5 Y 6 / 4)$; very micaceous

28. Shale, very carbonaceous, brownish-black (5YR 2/1); weathers to brownish gray $(5 Y R 4 / 1)$

27. Coal, blocky, bright, brown when cut, hard.

26. Siltstone, thin-bedded, tuffaceous, clayey, carbonaceous, brownish-black (5YR 2/1); weathers to light brownish gray ( $5 Y R$ 6/1)

25. Coal, bony, flaky, dull; contains a few bright streaks.

24. Shale, very carbonaceous, brownish-black (5YR 2/1); weathers to brownish gray $(5 Y R$ 4/1) . . . . . . . . .

23. Coal, bony, flaky, dull; contains a few bright streaks.

19

22. Sandstone, thin-bedded, very fine grained, silty, dusky-yellow-green $(5 G Y \quad 5 / 2)$; weathers to dusky yellow $(5 Y 6 / 4) \ldots \ldots . .$.

21. Coal, bony, flaky, dull; contains a few bright streaks.

20. Shale, very carbonaceous, brownish-black (5YR 2/1); weathers to brcwnish gray (5YR 4/1) . . . . . . . . . . . . . . . . . .

19. Sandstone, thin-bedded, very fine grained, silty, dusky-yellow-green $(5 G Y \quad 5 / 2)$; weathers to dusky yellow $(5 Y 6 / 4)$

19. Shale, very carbonaceous, brownish-black $(5 Y R 2 / 1)$; weathers to brownish gray (5YR 4/1) ...............................

17. Sandstone, thin-bedded, very fine grained, silty, dusky-yellow-green $(5 G Y 5 / 2)$; weathers to dusky yellow $(5 Y 6 / 4) \ldots \ldots$...

16. Coal, bony, flaky, dull; contains a few thin bright streaks..........................

15. Sandstone, thin-bedded, very fine grained, silty, dusky-yellow-green (5GY 5/2); weathers to dusky yellow $(5 Y 6 / 4) \ldots \ldots$.

14. Siltstone, thin-bedded, very carbonaceous, brownish-black $(5 Y R 2 / 1)$; weathers to light brownish gray $(5 Y R 6 / 1) \ldots \ldots$

13. Coal, bony, flaky, dull; contains a few thin (generally less than $1 / 8 \mathrm{in.}$ ) bright streaks. -

12. Siltstone, thin-bedded, very carbonaceous, brownish-black ( $5 Y R 2 / 1)$; weathers to light brownish gray $(5 Y R 6 / 1) \ldots \ldots \ldots$

11. Sandstone, thin-bedded, very fine grained, silty, dusky-yellow-green (5GY $5 / 2)$; weathers to dusky yellow $(5 Y 6 / 4) \ldots \ldots$.

10. Siltstone, thin-bedded, very carbonaceous, brownish-black ( $5 Y R 2 / 1)$; weathers to light brownish gray $(5 Y R 6 / 1) \ldots \ldots \ldots$

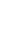

5




\section{SECTION 16-Continued}

Type section of the Cokedale Formation of the Livingston Group, measured in the $S 1 / 2$ sec. 23 and the NE1/4 sec. 26, T. $2 S ., R$. $8 \dot{E}$., Park County, Mont.-Continued

Upper Cretaceous-Livingston Group-Cokedale Formation-Continued

9. Sandstone, thin-bedded, very fine grained, silty, dusky-yellow-green $(5 G Y \quad 5 / 2)$; weathers to dusky vellow $(5 Y 6 / 4) \ldots . .$.

8. Sandstone, volcanic, massive to thin-bedded, fint-grained, andesitic, dusky-yellow-green (5GY 5/2); weathers to dusky yellow ( $5 Y$ $6 / 4)$; locally calcareous, containing many large (2-3 ft in diameter) calcareous spheroidal concretions; contains macerated plant fragments. . . . . . . . . . . . . . .

7. Bentonite, silty

6. Sandstone, volcanic, thin-bedded, very fine grained, silty, andesitic, dusky-yellowgreen $(5 G Y 5 / 2)$; weathers to dusky yellow (5Y 6/4); contains streaks of coal and plant fragments....................

5. Siltstone, medium-bedded, well-indurated, olive-gray ( $5 Y 3 / 2)$; weathers to light olive gray ( $5 Y 5 / 2)$; contains macerated plant fragments. ...................

4. Claystone, medium-bedded, olive-gray ( $5 Y$ $4 / 1)$; weathers to light olive gray ( $5 Y 6 / 1)$.

3. Siltstone, thick-bedded, well-indurated, olive-gray ( $5 Y 3 / 2)$; weathers to light olive gray $(5 Y 5 / 2) \ldots \ldots$

2. Claystone, medium-bedded, olive-gray ( $5 Y$ $4 / 1)$; weathers to light olive gray $(5 Y 6 / 1)$

1. Mudstone, thin-bedded, very carbonaceous, bentonitic, grayish-brown $(5 Y R 3 / 2)$; weathers to pale yellowish brown $(10 Y R 6 / 2)$.

Total thickness of Cokedale Forma-

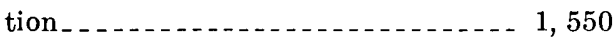

Upper Cretaceous-Eagle Sandstone.

\section{MINER CREEK FORMATION}

Stratigraphic section 17 of the Miner Creek Formation of the Livingston Group, measured near the abandoned townsite of Cokedale, Mont. (sections 3 and 4, fig. 15), is the type section of the formation.

\section{SECTION 17}

Type section of the Mintr Creek Formation of the Livingston Group, measured in the $N^{11 / 4}$ sec. 20 and E1/2 sec. 19, T. 2 S., R. 9 E., Park County, Mont.

[Measured by A. E. Roberts and A. L. Benson, 1961]

Upper Cretaceous-Livingston Group-Billman Creek Formation.

Upper Cretaceous-Livingston Group-Miner Creek Formation:

155. Sandstone, volcanic, thin-bedded to massive, fine-grained, andesitic, dark-greenish-gray ( $5 G Y 4 / 1)$; weathers to greenish gray ( $5 G Y 6 / 1)$; contains a few calcareous concretions as much as $8 \mathrm{in}$. in diameter; prominent ridge former

\section{SECTION 17-Continued}

Type section of the Miner Creek Formation of the Livingston Group, measured in the $N W_{1 / 4}^{1 / 4}$ sec. 20 and $E 1 / 2$ sec. 19, T. $2 S$., R. $9 \mathrm{E}$., Park County, Mont.-Continued

Upper Cretaceous-Livingston Group-Miner Creek Formation-Continued

Ft In.

154. Siltstone, massive, olive-gray (5Y 4/1); weathers to light olive gray (5Y 6/1); US GS Paleobotany loc. D1613

153. Sandstone, volcanic, medium-bedded to massive, fine-grained, andesitic, grayishgreen $(10 G Y 5 / 2)$; weathers to light olive gray $(5 Y 6 / 1) \ldots \ldots$

152. Siltstone, massive, olive-gray (5Y 4/1); weathers to light olive gray $(5 Y 6 / 1) \ldots$

151. Sandstone, volcanic, thin-bedded, finegrained, andesitic, medium-light-gray $(N 6)$; weathers to light olive gray (5Y 6/1) . . . . . . .

150. Siltstone, massive, olive-gray (5Y 4/1); weathers to light olive gray $(5 Y 6 / 1)$

149. Sandstone, volcanic,- thin- to mediumbedded, fine-grained, andesitic, mediumlight-gray (N6); weathers to yellowish gray $(5 Y 7 / 2) \ldots \ldots$

148. Siltstone, massive, olive-gray (5Y 4/1); weathers to light olive gray $(5 Y 6 / 1) \ldots$

147. Sandstone, volcanic, medium-bedded, finegrained, silty, andesitic, olive-gray (5Y $4 / 1$ ); weathers to light olive gray (5Y $6 / 1)$

146. Siltstone, massive, olive-gray (5Y $4 / 1)$; weathers to light olive gray $(5 Y 6 / 1) \ldots$

145. Sandstone, volcanic, medium-bedded, finegrained, silty, andesitic, olive-gray ( $5 Y$ $4 / 1$ ); weathers to light olive gray ( $5 Y$

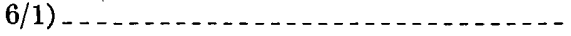

144. Siltstone, massive, olive-gray (5Y 4/1); weathers to light olive gray $(5 Y 6 / 1) \ldots$

143. Sandstone, volcanic, thin-bedded, finegrained, andesitic, medium-light-gray $(N 6)$; weathers to light gray $(N 7) \ldots . . .-$

142. Siltstone, massive, olive-gray (5Y $4 / 1)$; weathers to light olive gray $(5 Y 6 / 1)$

141. Sandstone, volcanic, medium-bedded, crossbedded, fine-grained, andesitic, lightgray (N7); has banded character imparted by thin (less than 1/16 in.) layers of ferromagnesian minerals on bedding planes; weathers to yellowish gray ( $5 Y$ 8/1) . . . . . . . . . . . . . . . . . . . . .

140. Siltstone, massive, olive-gray (5Y 4/1); weathers to light olive gray $(5 Y 6 / 1) \ldots$

139. Sandstone, volcanic, massive, fine-grained, andesitic, medium-light-gray (N6); weathers to light gray $(N 7) \ldots$

138. Siltstone, massive, olive-gray ( $5 Y$ 4/1); weathers to light olive gray $(5 Y 6 / 1) \ldots$

137. Sandstone, volcanic, medium-bedded, finegrained, andesitic, medium-light-gray $(N 6)$; weathers to light gray $(N 7) \ldots . .$.

136. Siltstone, massive, olive-gray (5Y 4/1); weathers to light olive gray $(5 Y 6 / 1) \ldots$
$21 \quad 1$

$8 \quad 2$

$146 \quad 6$

$2 \quad 2$

$145 \quad 11$

18

$14 \quad 11$

34

9

$26 \quad 5$

20

$11 \quad 10$

111

$39 \quad 3$

42

$6 \quad 4$

11

161 


\section{SECTION 17-Continued}

Type section of the Miner Creek Formation of the Livingston Group, measured in the $N W 1 / 4$ sec. 20 and E1/2 sec. 19, T. $2 S .$, R. 9 E., Park County, Mont.-Continued

Upper Cretaceous-Livingston Group-Miner Creek Formation-Continued

135. Sandstone, volcanic, medium-bedded, finegrained, andesitic, medium-light-gray (N6); weathers to light gray (N7)

134. Siltstone, medium-bedded, olive-gray $(5 Y$ $4 / 1)$; weathers to light olive gray ( $5 Y$ $6 / 1)$

133. Sandstone, volcanic, medium-bedded, finegrained, andesitic, greenish-gray ( $5 G Y$ $6 / 1)$; weathers to light olive gray ( $5 Y$ $6 / 1)$

132. Siltstone, medium-bedded, olive-gray ( $5 Y$ $4 / 1)$; weathers to light olive gray ( $5 Y$ $6 / 1)$

131. Sandstone, volcanic, thin-bedded, fine grained, andesitic, greenish-gray (5GY $6 / 1)$; weathers to light olive gray ( $5 Y 6 / 1)$

130. Siltstone, massive, olive-gray (5Y 4/1); weathers to light olive gray $(5 Y 6 / 1) \ldots$

129. Sandstone, volcanic, thick-bedded, fine. grained, andesitic, greenish-gray (5GY $6 / 1$ ); weathers to light olive gray ( $5 Y$ 6/1)

128. Siltstone, medium-bedded, olive-gray ( $5 Y$ $4 / 1)$; weathers to light olive gray ( $5 Y$

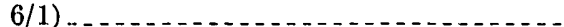

127. Sandstone, volcanic, thin-bedded to massive, fine-grained, andesitic, greenishgray ( $5 G Y 6 / 1)$; weathers to light olive gray $(5 Y 6 / 1)$; prominent ridge former ..-

126. Siltstone, medium-bedded, olive-gray ( $5 Y$ $4 / 1$ ) ; weathers to light olive gray ( $5 Y 6 / 1)$.

125. Sandstone, volcanic, thin- to thickbedded, fine-grained, andesitic, grayishgreen $(5 G 5 / 2)$; weathers to yellowish gray $(5 Y 7 / 2)$

124. Siltstone, massive, tuffaceous, olive-gray (5Y 4/1); weathers to light olive gray $(5 Y 6 / 1)$

123. Sandstone, volcanic, thin-bedded to massive, crossbedded, fine- to medium-grained, andesitic, grayish-green ( $5 G 5 / 2)$; weathers to yellowish gray $(5 Y 7 / 2)$; prominent ridge former.....................

122. Covered interval-probably siltstone, olive-

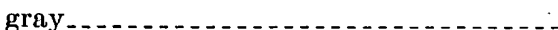

121. Sandstone, volcanic, massive, crossbedded, fine- to coarse-grained, poorly sorted, andesitic, medium-light-gray (N6); weathers to yellowish gray $(5 Y 8 / 1)$ and white..............................

120. Covered interval-probably siltstone, olive-

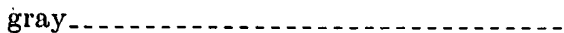

119. Sandstone, volcanic, thin-bedded to massive, crossbedded, fine- to mediumgrained, andesitic, well-indurated, medium-light-gray ( $N 6)$; weathers to light olive gray ( $5 Y 6 / 1)$; contains dinosaur bone fragments; ridge former

\section{SECTION 17-Continued}

Type section of the Miner Creek Formation of the Livingston Group, measured in the $N W 1 / 4$ sec. 20 and E1/2 sec. 19, T. 2 S., R. 9 E., Park County, Mont.-Continued

Upper Cretaceous-Livingston Group-Miner Creek Formation-Continued

Fi In.

118. Covered interval-probably siltstone, olivegray

117. Sandstone, volcanic, thick-bedded, finegrained, andesitic, grayish-green ( $5 G$ $5 / 2)$; weathers to olive gray ( $5 Y 4 / 1) \ldots$

116. Covered interval-probably siltstone, olivegray

115. Sandstone, volcanic, medium-bedded, finegrained, andesitic, grayish-green ( $5 G$ $5 / 2)$; weathers to olive gray $(5 Y 4 / 1) \ldots \ldots$

114. Siltstone, medium-bedded, olive-gray ( $5 Y$ $4 / 1)$; weathers to light olive gray ( $5 Y 6 / 1)$ -

113. Sandstone, volcanic, medium- to thickbedded, fine-giained, andesitic, grayishgreen $(5 G 5 / 2)$; weathers to olive gray $(5 Y 4 / 1)$

112. Siltstone, thick-bedded, olive-gray ( $5 Y 4 / 1)$; weathers to light olive gray $(5 Y 6 / 1) \ldots$

111. Sandstone, volcanic, thick-bedded, fineto coarse-grained, poorly sorted, andesitic, grayish-green ( $5 G 5 / 2)$; weathers to olive gray (5Y 4/1) ................

110. Covered interval-probably siltstone, olivegray

109. Sandstone, volcanic, thin-bedded, very fine grained, andesitic, greenish-gray ( $5 G Y$ $6 / 1$ ); weathers to yellowish gray ( $5 Y$ $7 / 2)$; contains abundant bronze-colored biotite............................

108. Siltstone, medium-bedded, olive-gray ( $5 Y$ $4 / 1$ ) ; weathers to light olive gray ( $5 Y 6 / 1)$ contains wood and plant fragments.....

107. Sandstone, volcanic, medium-bedded, fineto medium-grained, poorly sorted, andesitic, medium-light-gray ( $N 6)$; weathers to light gray $(N 7) \ldots \ldots$

106. Siltstone, massive, olive-gray ( $5 Y 4 / 1)$; weathers to light olive gray ( $5 Y 6 / 1)$; poorly exposed.....................

105. Sandstone, volcanic, massive, fine-grained, andesitic, well-indurated, grayish-green ( $10 G Y 5 / 2)$; weathers to grayish yellow green ( $5 G Y 7 / 2)$; ridge former........

104. Siltstone, massive, olive-gray ( $5 Y 4 / 1)$; weathers to light olive gray $(5 Y 6 / 1)$

103. Sandstone, volcanic, medium- to thickbedded, crossbedded, fine-grained, silty, andesitic; contains many mudstone balls-generally along bedding planes; grayish-green ( $5 G \quad 5 / 2)$; weathers to grayish yellow green $(5 G Y 7 / 2) \ldots \ldots \ldots$

102. Siltstone, thick-bedded, dusky-yellow-green ( $5 G Y 5 / 2)$; weathers to grayish yellow green $(5 G Y 7 / 2)$

$95 \quad 5$

36

$23 \quad 3$

14

18

38

38

$5 \quad 2$

$35 \quad 5$

$1 \quad 2$

$5 \quad 2$

14

$32 \quad 8$

128

112

101. Sandstone, volcanic, medium-bedded, finegrained, andesitic, dusky-yellow-green ( $5 G Y 5 / 2)$; weathers to pale yellowish brown $(10 Y R 6 / 2)$
40

30

11 


\section{SECTION 17-Continued}

Type section of the Miner Creek Formation of the Livingston Group, measured in the $N W 1 / 4$ sec. 20 and $E 1 / 2$ sec. 19, T. $2 S$., R. $9 E$., Park County, Mont.-Continued

Upper Cretaceous-Livingston Group-Miner Creek Formation-Continued

100. Siltstone, medium-bedded, dusky-yellowgreen ( $5 G Y 5 / 2)$; weathers to grayish yellow green $(5 G Y 7 / 2)$

99. Sandstone, volcanic, thin-bedded, finegrained, andesitic, dusky-yellow-green ( $5 \mathrm{GY} 5 / 2)$; weathers to pale yellowish brown $(10 Y R 6 / 2) \ldots$

98. Siltstone, medium-bedded, dusky-yellowgreen $(5 G Y 5 / 2)$; weathers to grayish yellow green $(5 G Y 7 / 2) \ldots$

97. Sandstone, volcanic, thin-bedded, finegrained, andesitic, dusky-yellow-green ( $5 G Y 5 / 2)$; weathers to pale yellowish brown $(10 Y R$ 6/2) .................

96. Siltstone, massive, dusky-yellow-green $(5 G Y 5 / 2)$; weathers to grayish yellow green $(5 G Y 7 / 2)$

95. Sandstone, volcanic, thick-bedded, finegrained, andesitic, dusky-yellow-green $(5 G Y 5 / 2)$; weathers to pale yellowish brown $(10 Y R$ 6/2) .................

94. Siltstone, massive, dusky-yellow-green $(5 G Y 5 / 2)$; weathers to grayish yellow green ( $5 G Y 7 / 2)$

93. Sandstone, volcanic, massive to thinbedded, fine-grained, andesitic, wellindurated, dusky-yellow-green (5GY $5 / 2)$; weathers to pale yellowish brown (10YR 6/2); ridge former............

92. Siltstone, thin-bedded, dusky-yellow-green ( $5 G Y 5 / 2$ ); weathers to grayish yellow green $(5 G Y 7 / 2)$

91. Sandstone, volcanic, thin-bedded, finegrained, silty, andesitic, light-olivegray ( $5 Y 5 / 2)$; weathers to yellowish gray $(5 Y 7 / 2) \ldots \ldots$

90. Siltstone, thin-bedded, dusky-yellow-green $(5 G Y 5 / 2)$; weathers to grayish yellow green $(5 G Y 7 / 2)$

89. Sandstone, volcanic, thin-bedded, fine grained, silty, andesitic, light-olive-gray $(5 Y 5 / 2)$; weathers to yellowish gray $(5 Y 7 / 2)$ -

88. Siltstone, thin-bedded, dusky-yellow-green $(5 G Y 5 / 2)$; weathers to grayish yellow green $(5 G Y 7 / 2)$

87. Sandstone, volcanic, thin-bedded, finegrained, silty, andesitic, light-olive-gray $(5 Y 5 / 2)$; weathers to yellowish gray ( $5 \mathrm{Y}$ $7 / 2)$

86. Siltstone, massive, dusky-yellow-green ( $5 G Y 5 / 2)$; contains red specks of heulandite; weathers to grayish yellow green $(5 G Y 7 / 2)$

85. Sandstone, volcanic, thick-bedded, finegrained, silty, andesitic, well-indurated, light-olive-gray $(5 Y \quad 5 / 2)$; weathers to yellowish gray ( $5 Y 7 / 2)$; contains macerated plant fragments; ridge former.....

\section{SECTION 17-Continued}

Type section of the Miner Creek Formation of the Livingston Group, measured in the $N W 1 / 4$ sec. 20 and $E 1 / 2$ sec. 19, T. 2 S., R. 9 E., Park County, Mont.-Continued

Upper Cretaceous-Livingston Group-Miner Creek Formation-Continued

Ft In

84. Siltstone, massive, dusky-yellow-green ( $5 G Y$ $5 / 2)$; red specks of heulandite common; contains some fine sand; weathers to grayish yellow green $(5 G Y 7 / 2)$

83. Sandstone, volcanic, thin- to thick-bedded, fine-grained, andesitic, well-indurated, grayish-olive-green ( $5 G Y 3 / 2$ ); abundant bronze-colored biotite and hornblende; weathers to greenish gray ( $5 G Y 6 / 1)$

82. Sandstone, volcanic, medium-bedded to massive, fine- to medium-grained, andesitic, well-indurated, greenish-gray ( $5 G Y$ $6 / 1$ ) ; fills channels as much as $3.5 \mathrm{ft}$ deep in underlying siltstone; abundant bronzecolored biotite; weathers to moderate brown $(5 Y R 4 / 4)$

81. Siltstone, thick-bedded, grayish-olive $4 / 2)$; weathers to pale olive $(10 Y 6 / 2)$

80. Sandstone, volcanic, medium-bedded, finegrained, andesitic, medium-light-gray (N6); weathers to light gray (N7) ......

79. Siltstone, medium-bedded, grayish-olive (10Y $4 / 2)$; weathers to pale olive $(10 Y 6 / 2)$.

78. Sandstone, volcanic, medium- to thickbedded, fine-grained, andesitic, mediumlight-gray (N6); weathers to light gray $(N 7)$

77. Siltstone, medium-bedded, olive-gray $(5 Y$ $4 / 1$ ); weathers to light olive gray ( $5 Y$ $6 / 1)$; contains macerated plant fragments; USGS Paleobotany loc. D1612 ........

76. Sandstone, volcanic, medium-bedded, finegrained, andesitic; contains red specks of heulandite

75. Siltstone, thick-bedded, grayish-olive-green ( $5 G Y 3 / 2)$; weathers to grayish yellow green $(5 G Y 7 / 2)$

74. Sandstone, volcanic, medium-bedded, finegrained, andesitic, medium-light-gray (N6); contains red specks of heulandite; weathers to light gray $(N 7)$

73. Siltstone, massive, grayish-olive-green, ( $5 G Y$ $3 / 2)$; weathers to grayish yellow green $(5 G Y 7 / 2)$

72. Sandstone, volcanic, medium-bedded, fineto medium-grained, andesitic, mediumlight-gray $(N 6)$; contains red specks of heulandite; weathers to light gray $(N 7)$ - -

71. Siltstone, thick-bedded, grayish-olive-green $(5 G Y 3 / 2)$; weathers to grayish yellow green $(5 G Y 7 / 2)$

70. Sandstone, volcanic, thin-bedded, finegrained, andesitic, medium-light-gray (N6); contains red specks of heulandite; weathers to light gray $(N 7) \ldots . . . . . . .$.

69. Siltstone, medium-bedded, grayish-olivegreen ( $5 G Y 3 / 2)$; weathers to grayish yellow green $(5 G Y 7 / 2) \ldots \ldots$ 


\section{SECTION 17-Continued}

Type section of the Miner Creek Formation of the Livingston Group, measured in the $N W 1 / 4$ sec. 20 and $E 1 / 2$ sec. 19, T. $2 S$., R. $9 E$., Park County, Mont.-Continued

Upper Cretaceous-Livingston Group-Miner Creek Formation-Continued

68. Sandstone, volcanic, thin-bedded, finegrained, andesitic, medium-light-gray $(N 6)$; contains red specks of heulandite; weathers to light gray $(N 7)$

67. Siltstone, thick-bedded, grayish-olive-green $(5 G Y 3 / 2)$; weathers to grayish yellow green $(5 G Y 7 / 2) \ldots$

66. Sandstone, volcanic, thin-bedded, finegrained, andesitic, medium-light-gray $(N 6)$; contains bronze-colored biotite; weathers to light gray (N7); contains macerated plant fragments...........

65. Siltstone, massive, tuffaceous, grayish-olivegreen $(5 G Y 3 / 2)$; contains red specks of heulandite; weathers to grayish yellow green $(5 G Y 7 / 2)$

64. Sandstone, volcanic, medium-bedded, very fine grained, silty, andesitic, greenish-gray (5GY 6/1); weathers to light greenish gray (5GY 8/1) . . . . . . . . . . . . . . . . .

63. Siltstone, massive, dusky-yellow-green ( $5 G Y 5 / 2)$; weathers to grayish yellow

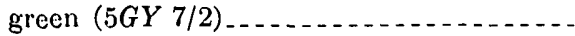

62. Sandstone, volcanic medium-bedded, very fine grained, silty, andesitic, dark-yellowish-brown (10YR 4/2); weathers to pale yellowish brown (10YR 6/2); contains macerated plant fragments . . . . . . .....

61. Siltstone, thick-bedded, dusky-yellow-green $(5 G Y 5 / 2)$; weathers to grayish yellow green $(5 G Y 7 / 2)$

60. Bentonite . . . . . . . .

59. Siltstone, thick-bedded, dusky-yellow-green ( $5 G Y 5 / 2)$; weathers to grayish yellow green $(5 G Y 7 / 2) \ldots \ldots$

58. Sandstone, volcanic, thick-bedded, finegrained, silty, andesitic, dark-greenishgray ( $5 G Y$ 4/1); weathers to yellowish gray $(5 Y 8 / 1) \ldots \ldots$

57. Siltstone, massive tuffaceous, dusky-yellowgreen ( $5 G Y 5 / 2)$; weathers to grayish yellow green $(5 G Y 7 / 2)$

56. Sandstone, volcanic, massive, fine- to coarsegrained, poorly sorted, andesitic, mediumlight-gray $(N 6)$; contains granules to small pebbles composed of volcanic rock at. base; weathers to light gray (N7) .......

55. Siltstone, thick-bedded, dusky-yellowgreen ( $5 G Y 5 / 2)$; contains vienlets and red specks of heulandite; weathers to grayish yellow green $(5 G Y 7 / 2)$

54. Sandstone, volcanic, medium-bedded to massive, crossbedded, fine- to coarsegrained, poorly sorted, andesitic, mediumlight-gray (N6); contains granules and small pebbles composed of volcanic rocks; weathers to light gray $(N 7)$, with limonitic staining-

$21 \quad 10$
210 10

34

20

$27 \quad 3$

59

24

SECTION 17-Continued

Type section of the Miner Creek Formation of the Livingston Group, measured in the $N W 1 / 4$ sec. 20 and $E 1 / 2$ sec. 19, T. 2 S., R. 9 E., Park County, Mont.-Continued

Upper Cretaceous-Livingston Group-Miner Creek Formation-Continued

Ft In.

53. Siltstone; massive, tuffaceous, olive-gray $(5 Y 3 / 2)$; weathers to yellowish gray (5Y $7 / 2)$

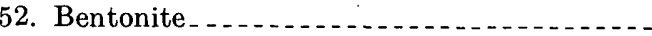

51. Siltstone, massive, tuffaceous, olive-gray ( $5 Y 3 / 2)$; contains silica-cemented concretions-generally 3-6 in. in diameter; lower $2 \mathrm{ft}$ grades downward into a very fine grained silty sandstone; weathers to yellowish gray $(5 Y 7 / 2)$

50. Sandstone, volcanic, medium-bedded to massive, fine- to coarse-grained, poorly sorted, andesitic, dark-greenish-gray ( $5 G Y 4 / 1)$; contains mudstone pebbles; weathers to moderate brown (5YR 4/4) ............

49. Siltstone, massive, dark-yellowish-brown $(10 Y R 4 / 2)$; weathers to pale yellowish brown (10YR 6/2); contains macerated plant fragments.....................

14 48. Siltstone, medium-bedded, tuffaceous, wellindurated, medium-dark-gray (N4); contains bronze-colored biotite; weathers to moderate brown (5YR 4/4)

47. Tuff, silicified, well-indurated, light-greenishgray ( $5 G Y 8 / 1)$; contains bronze-colored - biotite; this unit might have originally been dark gray and then leached; weathers to yellowish gray $(5 Y 7 / 2) \ldots \ldots$

46. Siltstone, massive, olive-gray $(5 Y 3 / 2)$; weathers to yellowish gray $(5 Y 7 / 2)$; poorly

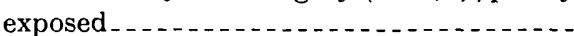

45. Sandstone, volcanic, medium-bedded, fineto coarse-grained, andesitic, dusky-yellowgreen ( $5 G Y 5 / 2)$; weathers to light olive gray $(5 Y 5 / 2) \ldots \ldots \ldots$

44. Siltstone, massive, olive-gray ( $5 Y \quad 3 / 2)$; weathers to yellowish gray $(5 Y 7 / 2)$; poorly exposed...........................

109

110

$48 \quad 2$

42

214

8

$3 \quad 6$

$18 \quad 1$

Total Miner Creek Formation that lies above the Sulphur Flats Sandstone Member................... 1, $190 \quad 0$

Sulphur Flats Sandstone Member:

43. Sandstone, volcanic, thin-bedded to massive, crossbedded, fine- to coarse-grained, poorly sorted, well-indurated, andesitic, light-brownish-gray $(5 Y R 6 / 1)$ to grayishgreen ( $5 G 5 / 2)$; contains bronze-colored biotite; weathers to light olive gray ( $5 Y$ $5 / 2)$; ridge former . . . . .

42. Siltstone, medium-bedded, olive-gray (5Y $4 / 1)$; weathers to pale olive $(10 Y 6 / 2)$...-

41. Tuff, medium-bedded, grayish-green $(5 G$ $5 / 2$ ) and light-brownish-gray (5YR 6/1); weathers to light olive gray $(5 Y 6 / 1) \ldots$

104

10

40. Sandstone, volcanic, thick-bedded, finegrained, andesitic, greenish-gray (5GY $6 / 1)$; weathers to olive gray $(5 Y 4 / 1) \ldots$
42 . 


\section{SECTION 17-Continued}

Type section of the Miner Creek Formation of the Livingston Group, measured in the NW1/4 sec. 20 and $E \frac{1 / 2}{1}$ sec. 19, T. $2 S ., R .9 E$., Park County, Mont.-Continued

Upper Cretaceous-Livingston Group-Miner Creek Formation-Continued

Sulphur Flats Sandstone Member-Continued

39. Tuff, medium-bedded, grayish-green (5G $5 / 2)$ and light-brownish-gray $(5 Y R 6 / 1)$; weathers to light olive gray $(5 Y 6 / 1)$....-

38. Sandstone, volcanic, thick-bedded, finegrained, andesitic, greenish-gray (5GY $6 / 1)$; weathers to olive gray $(5 Y 4 / 1)$

37. Sandstone, volcanic, massive, fine- to coarsegrained, poorly sorted, andesitic, grayishgreen $(5 G 5 / 2)$; weathers to light olive gray $(5 Y 5 / 2)$; ridge former

36. Tuff, medium-bedded, silicified, light-olivegray $(5 Y 5 / 2)$; weathers to moderate yellowish brown (10YR 5/4); contains macerated plant fragments. . . . .........

35. Sandstone, volcanic, thin-bedded, mediumgrained, andesitic, greenish-gray ( $5 G Y$ $6 / 1)$; weathers to olive gray $(5 Y 4 / 1) \ldots . .$.

34. Siltstone, tuffaceous, well-indurated, lightolive-gray $(5 Y 5 / 2)$ with streaks of lightbrownish-gray $(5 Y R \quad 6 / 1)$; weathers to light olive gray $(5 Y 6 / 1)$; contains a few leaf imprints.

33. Sandstone, volcanic, thin-bedded, mediumgrained, andesitic, greenish-gray ( $5 G Y$ $6 / 1)$; weathers to olive gray $(5 Y 4 / 1) \ldots$

32. Tuff, thin-bedded, light-brownish-gray ( $5 Y R$ $6 / 1)$; weathers to light olive gray ( $5 Y 6 / 1)$.

31. Sandstone, volcanic, thin-bedded, mediumgrained, andesitic, greenish-gray $(5 G Y$ $6 / 1)$; weathers to olive gray $(5 Y 4 / 1) \ldots$

30. Tuff, medium-bedded; light-brownish-gray (5YR 6/1); weathers to light olive gray (5Y 6/1); lowest 10 in. well-indurated....

29. Sandstone, volcanic, thin-bedded to massive, crossbedded, fine- to medium-grained, andesitic, grayish-green ( $5 G 5 / 2$ ); has banded character imparted by thin (less than $1 / 16$ in.) layers of ferromagnesian minerals on bedding planes; weathers to dark yellowish brown $(10 Y R 4 / 2)$; ridge former -

28. Siltstone, thick-bedded, medium-light-gray $(N 6)$; weathers to olive gray $(5 Y 4 / 1) \ldots$

27. Sandstone, volcanic, medium-bedded, fineto coarse-grained, poorly sorted, andesitic grayish-green $(5 G 5 / 2)$; weathers to light olive gray $(5 Y 5 / 2) \ldots$

26. Siltstone, medium-bedded, medium-lightgray $(N 6)$; weathers to olive gray $(5 Y 4 / 1)$; lowest $1 \mathrm{ft}$ well-indurated............

25. Sandstone, volcanic, locally conglomeratic, massive, crossbedded, fine- to coarsegrained, poorly sorted, andesitic, grayishgreen $(5 G 5 / 2)$; weathers to light olive gray $(5 Y 5 / 2)$; locally contains pebbles and

\section{SECTION 17-Continued}

Type section of the Miner Creek Formation of the Livingston Group, measured in the NW1/4 sec. 20 and E1/2 sec. 19, T. 2 S., R. 9 E., Park County, Mont.-Continued

Upper Cretaceous-Livingston Group-Miner Creek Formation-Continued

Ft In

Sulphur Flats Sandstone Member--Continued cobbles of volcanic rock; contains fragments of dinosaur bones; ridge former ... -
10

20

1
24. Siltstone, thin-bedded, greenish-gray ( $5 G Y$ $6 / 1)$; contains some clay and fine sand; weathers to pale olive $(10 Y 6 / 2) \ldots . . . .$.

23. Sandstone, volcanic, thin- to thick-bedded, crossbedded, fine- to coarse-grained, poorly sorted, andesitic, dusky-yellow-green ( $5 G Y 5 / 2)$; weathers to light olive gray (5Y 5/2); ridge former ................

22. Tuff, medium-bedded, light-olive-gray $(5 Y$ $6 / 1)$; weathers to yellowish gray $(5 Y 7 / 2)$ -

21. Sandstone, volcanic, medium-bedded, finegrained, andesitic, dusky-yellow-green $(5 G Y 5 / 2)$; weathers to pale yellowish brown $(10 Y R 6 / 2)$

20. Tuff, medium-bedded, light-olive-gray (5Y $6 / 1)$; weathers to yellowish gray ( $5 Y$ 7/2) _.............................

19. Sandstone, volcanic, massive, crossbedded, fine- to coarse-grained, andesitic, wellindurated, dusky-yellow-green ( $5 G Y 5 / 2)$; weathers to pale yellowish brown (10YR 6/2) ; ridge former . . . . . . . . . . . . . . .

18. Siltstone, medium-bedded, tuffaceous, olivegray $(5 Y 3 / 2)$; weathers to light olive gray $(5 Y 5 / 2)$

17. Siltstone, medium-bedded, tuffaceous, wellindurated, pale-yellowish-brown $(10 Y R$ $6 / 2)$; weathers to yellowish gray $(5 Y 7 / 2)$; contains macerated plant fragments . . . . -

16. Siltstone, medium-bedded, tuffaceous, olivegray $(5 Y 3 / 2)$; weathers to light olive gray (5Y 5/2) _............................

15. Siltstone, medium-bedded, sandy, tuffaceous, medium-dark-gray $(N 4)$; weathers to moderate brown (5YR 4/4); contains macerated plant fragments.................

14. Siltstone, medium-bedded, tuffaceous, olivegray $(5 Y 3 / 2)$; weathers to light olive gray (5Y 5/2) . . . .

13. Sandstone, volcanic, medium-bedded, finegrained, andesitic, dusky-yellow-green (5GY 5/2); weathers to greenish gray $(5 G Y 6,1) \ldots \ldots$

12. Siltstone, medium-bedded, tuffaceous, olivegray $(5 Y 3 / 2)$; weathers to light olive gray

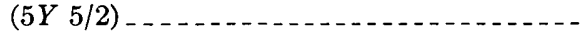

11. Siltstone, medium-bedded, tuffaceous, olivegray $(5 Y 4 / 1)$; weathers to light olive gray (5Y 5/2); contains macerated plant fragments..............................

10. Siltstone, medium-bedded, tuffaceous, olivegray $(5 Y 3 / 2)$; weathers to light olive gray $(5 Y 5 / 2) \ldots \ldots \ldots$
$26 \quad 0$

$4 \quad 1$

26

11

$4 \quad 6$

11 


\section{SECTION 17-Continued}

Type section of the Miner Creek Formation of the Livingston Group, measured in the $N W 14$ sec. 20 and $E \frac{1}{2}$ sec. 19, T. $2 S ., R .9 E$., Park County, Mont.-Continued

Upper Cretaceous-Livingston Group-Miner Creek Formation-Continued

Sulphur Flats Sandstone Member-Continued

9. Tuff, medium-bedded, well-indurated, lightbrownish-gray (5YR 6/1); weathers to yellowish gray $(5 Y 7 / 2)$; slight tendency to form ridges.............

8. Siltstone, massive, tuffaceous, olive-gray (5Y 3/2); weathers to light olive gray $(5 Y 5 / 2) \ldots$

7. Sandstone, volcanic, massive, cross bedded, fine- to medium-grained, andesitic, duskyyellow-green $(5 G Y 5 / 2)$; weathers to pale olive $(10 Y 6 / 2)$; mudstone pebbles as much as $2 \mathrm{in}$. in diameter in lowest $1 \mathrm{ft}$ of bed; slight tendency to form ridges..........

6. Siltstone, thick-bedded, tuffaceous, olivegray $(5 Y 3 / 2)$; weathers to light olive gray $(5 Y 5 / 2) \ldots \ldots$

5. Sandstone, volcanic, medium-bedded, finegrained, andesitic, grayish-yellow-green (5GY 7/2); weathers to pale olive $(10 Y 6 / 2) \ldots \ldots$

4. Siltstone, medium-bedded, tuffaceous, olivegray $(5 Y 3 / 2)$; weathers to light olive gray (5Y 5/2); contains petrified wood and macerated plant fragments . . . ..........

3. Sandstone, volcanic, massive, crossbedded, fine-grained, andesitic, grayish-yellowgreen $(5 G Y 7 / 2)$ weathers to pale olive $(10 Y 6 / 2)$; contains petrified wood; ridge

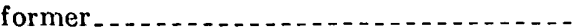

2. Siltstone, massive, tuffaceous, grayish-olivegreen ( $5 G Y 3 / 2)$; weathers to dusky yellow green $(5 G Y 5 / 2) \ldots$

1. Sandstone, quartzose, thin- to thick-bedded, fine-grained, mottled yellowish-gray ( $5 Y$ $8 / 1$ ) and yellowish-gray ( $5 Y 7 / 2)$; contains calcareous lenses and stringers as much as 4 in. thick; weathers to pale yellowish brown (10YR 6/2); good marker bed due to its lithology and mottled light color; slight tendency to form ridiges...........

Total thickness of Sulphur Flats Sandstone Member

Total thickness of Miner Creek Formation

Upper Cretaceous-Livingston Group-Cokedale Formation.

\section{BILLMAN GREEK FORMATION}

Stratigraphic section 18 of the Billman Creek Formation of the Livingston Group, measured across the valley of Billman Creek north of the abandoned townsite of Cokedale, Mont. (sections 5-7, fig. 15), is the type section of the formation.

\section{SECTION 18}

Type section of the Billman Creek Formation of the Livingston Group, measured in the W12 sec. $18, T$. \& S., R. 9 E., and the S132 sec. 19, T. \& S., R. 8 E., Park County, Mont.

[Measured by A. E. Roberts and A. L. Benson, 1961]

Upper Cretaceous-Livingston Group-Hoppers

Formation.

Upper Cretaceous-Livingston Group-Billman

Creek Formation:

163. Claystone, massive, olive-black (5Y 2/1); weathers to light olive gray $(5 Y 6 / 1)$

162. Siltstone, thick-bedded, clayey, duskyyellow-green $(5 G Y 5 / 2)$; weathers to light olive gray $(5 Y 5 / 2) \ldots$

161. Claystone, massive, olive-black (5Y 2/1); weathers to light olive gray $(5 Y 6 / 1) \ldots .$.

160. Sandstone, volcanic, thin-bedded to massive, fine-grained, andesitic, calcareous, dusky-yellow-green ( $5 G Y 5 / 2)$; weathers to light olive gray $(5 Y 5 / 2) \ldots$

159. Claystone, massive, olive-black (5Y 2/1); weathers to light olive gray $(5 Y 6 / 1) \ldots$

158. Sandstone, volcanic, thin-bedded to massive, fine-grained, andesitic, calcareous, dusky-yellow-green ( $5 G Y 5 / 2)$; weathers to light olive gray $(5 Y 5 / 2) \ldots$

157. Claystone, massive, olive-black $\left(\begin{array}{ll}5 Y & 2 / 1\end{array}\right)$; weathers to light olive gray $(5 Y 6 / 1) \ldots$

156. Sandstone, volcanic, thin-bedded, crossbedded, fine-grained, andesitic, calcareous, dusky-yellow-green $(5 G Y \quad 5 / 2)$; weathers to grayish yellow green ( $5 G Y$

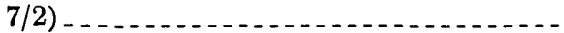

155. Mudstone, massive, olive-gray (5Y 4/1); weathers to light olive gray $(5 Y 6 / 1)$-.--

154. Sandstone, volcanic, thin-bedded, crossbedded, fine-grained, andesitic, calcareous, dusky-yellow-green $(5 G Y \quad 5 / 2)$; weathers to grayish yellow green $(5 G Y$ 7/2) - . - .

153. Claystone, thick-bedded, olive-gray (5Y $4 / 1)$; weathers to light olive gray ( $5 Y$ $6 / 1)$

Ft In.

16

26

$17 \quad 0$

36

112

$5 \quad 4$

109

18

$13 \quad 10$

36

32

152. Sandstone, volcanic, thin-bedded to massive, crossbedded, fine-grained, andesitic, dusky-yellow-green $(5 G Y \quad 5 / 2)$; has banded character imparted by thin (less than $1 / 16$ in.) layers of ferromagnesian minerals on bedding planes; massive spheroidal weathering; weathers to yellowish gray (5Y 7/2); contains plant fragments.........................

151. Mudstone, massive, olive-gray (5Y 4/1); weathers to light olive gray $(5 Y 6 / 1) \ldots$

150. Sandstone, volcanic, medium-bedded, finegrained, andesitic, calcareous, duskyyellow-green $(5 G Y \quad 5 / 2)$; weathers to grayish yellow green $(5 G Y 7 / 2) \ldots \ldots$

149. Claystone, thick-bedded, olive-gray ( $5 Y$ $4 / 1$ ); weathers to light olive gray ( $5 Y$ $6 / 1)$; contains calcareous nodules as much as 8 in. in diameter
$8 \quad 4$

114

18

30 


\section{SECTION 18-Continued}

Type section of the Billman Creek Formation of the Livingston Group, measured in the W1/2.sec. 18, T. $2 S$., R. 9 E., and the S1/2 sec. 13, T. 2 S., R. 8 E., Park County, Mont.-Continued

Upper Cretaceous-Livingston Group-Billman

Creek Formation-Continued

148. Sandstone, volcanic, medium-bedded, finegrained, andesitic, calcareous, duskyyellow-green $(5 G Y \quad 5 / 2)$; weathers to grayish yellow green $(5 G Y 7 / 2)$

147. Claystone, medium-bedded, olive-gray ( $5 Y$ $4 / 1)$; weathers to light olive gray (5Y $6 / 1)$

146. Sandstone, volcanic, medium-bedded, finegrained, andesitic, calcareous, duskyyellow-green ( $5 G Y 5 / 2)$; weathers to grayish yellow green $(5 G Y 7 / 2)$

145. Mudstone, massive, olive-gray (5Y $4 / 1)$; weathers to light olive gray $(5 Y 6 / 1) \ldots$

144. Sandstone, volcanic, thin-bedded to massive, fine-grained, andesitic, dusky-yellowgreen ( $5 G Y 5 / 2)$; has banded character imparted by thin (less than $1 / 16$ in.) layers of ferromagnesian minerals along bedding planes; contains calcareous nodules and stringers; weathers to yellowish gray (5Y 7/2); contains macerated plant fragments; ridge former.

143. Claystone, massive, olive-black ( $5 Y 2 / 1)$; weathers to olive gray $(5 Y 4 / 1)$

142. Sandstone, volcanic, thin- to mediumbedded, fine-grained, andesitic, calcareous, dusky-yellow-green (5GY 5/2); weathers to grayish yellow green $(5 G Y$ $7 / 2)$

141. Claystone, massive, olive-black (5Y 2/1); weathers to olive gray $(5 Y 4 / 1) \ldots \ldots .$.

1.40. Sandstone, volcanic, thin- to mediumbedded, fine-grained, andesitic, calcareous, dusky-yellow-green $(5 G Y \quad 5 / 2)$; weathers to grayish yellow green $(5 G Y$ $7 / 2$ )

139. Claystone, thick-bedded, brownish-black (5YR 2/1) and brownish-gray (5YR 4/1); weathers to light brownish gray $(5 Y R$ $6 / 1)$

138. Sandstone, volcanic, thin- to mediumbedded, fine-grained, andesitic, duskyyellow-green ( $5 G Y 5 / 2)$; weathers to grayish yellow green $(5 G Y 7 / 2) \ldots \ldots$

137. Siltstone, thick-bedded, olive-gray $(5 Y 4 / 1)$; weathers to light olive gray $(5 Y 6 / 1)$; contains macerated plant fragments; USGS Paleobotany loc. D4104-B

136. Claystone, medium-bedded, olive-black $(5 Y 2 / 1)$; weathers to light olive gray $(5 Y 6 / 1)$

135. Sandstone, volcanic, thin- to thick-bedded, fine-grained, andesitic, lower $2 \mathrm{ft}$ and upper $5 \mathrm{ft}$ are calcareous, dusky-yellowgreen $(5 G Y 5 / 2)$; weathers to greenish gray $(5 G Y 6 / 1)$

\section{SECTION 18-Continued}

Type section of the Billman Creek Formation of the Livingston Group, measured in the W1/2 sec. 18, T. 2 S., R. 9 E., and the S1/2 sec. 19, T. 2 S., R. 8 E., Park County, Mont.-Continued

Upper Cretaceous-Livingston Group-Billman

Creek Formation-Continued

134. Siltstone, massive, clayey, olive-gray ( $5 Y$ $4 / 1)$; weathers to light olive gray (5Y $6 / 1)$

133. Sandstone, volcanic, medium-bedded, finegrained, andesitic, dusky-yellow-green ( $5 G Y 5 / 2)$; weathers to light olive gray $\left(\begin{array}{ll}5 Y & 5 / 2\end{array}\right)$; somewhat brecciated and cemented by gypsum. ..............

132. Claystone, massive, olive-black (5 $\left.\begin{array}{ll}5 & 2 / 1\end{array}\right)$ and olive-gray $(5 Y 4 / 1)$; weathers to light olive gray $(5 Y 6 / 1) \ldots \ldots \ldots$

131. Sandstone, volcanic, medium-bedded, finegrained, andesitic, dusky-yellow-green $(5 G Y 5 / 2)$; weathers to light olive gray $(5 Y 5 / 2) \ldots \ldots$

130. Claystone, massive, olive-black (5Y 2/1); weathers to light olive gray $(5 Y 6 / 1) \ldots$

129. Sandstone, volcanic, medium-bedded, finegrained, andesitic, dusky-yellow-green ( $5 G Y 5 / 2)$; weathers to light olive gray

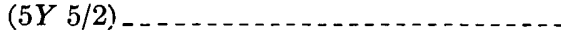

128. Claystone, massive, olive-black ( $5 Y$ 2/1 $)$ and olive-gray (5Y 4/1); weathers to light olive gray $(5 Y 6 / 1)$

127. Sandstone, volcanic, thin-bedded to massive, crossbedded, fine- to coarse-grained, poorly sorted (pebbles of volcanic rock as much as 2 in. in diameter are rare to common), adesitic, dusky-yellow-green $(5 G Y 5 / 2)$; weathers to light olive gray $(5 Y 5 / 2)$

126. Mudstone, massive, olive-gray (5Y 4/1); weathers to light olive gray $(5 Y 6 / 1)$; poorly exposed.

125. Sandstone, volcanic, thin-bedded to massive, crossbedded, fine- to coarse-grained, very poorly sorted (contains grains as large as granules), andesitic, duskyyellow-green $(5 G Y 5 / 2)$; weathers to light olive gray ( $5 Y 5 / 2)$; ridge former.-

124. Sandstone, volcanic, massive, crossbedded, fine- to medium-grained, andesitic, dusky-yellow-green (5GY 5/2); has banded character imparted by thin (less than $1 / 8$ in.) layers of ferromagnesian minerals on bedding planes; spheroidal weathering; weathers yellowish gray ( $5 Y$ $7 / 2)$; ridge former . . . . . . . . . . . . . . .

123. Mudstone, massive, olive-gray (5Y 4/1); weathers to light olive gray $(5 Y 6 / 1) \ldots$

122. Sandstone, volcanic, thin-bedded, crossbedded, fine- to medium-grained, andesitic, dusky-yellow-green $(5 G Y \quad 5 / 2)$; weathers to grayish yellow green $(5 G Y$ $7 / 2) \ldots$

121. Mudstone, massive, olive-gray (5Y 4/1); weathers to light olive gray $(5 Y 6 / 1) \ldots$.
Ft In 
SECTION 18 -Continued

Type section of the Billman Creek Formation of the Livingston Group, measured in the W1/2 sec. 18, T. $2 S$., R. $9 E$., and the SY2 sec. 19, T. 2 S., R. 8 E., Park County, Mont.-Continued

Upper Cretaceous-Livingston Group-Billman

Creek Formation-Continued

120. Sandstone, volcanic, thin-bedded, crossbedded, fine- to medium-grained, andesitic, dusky-yellow-green ( $5 G Y \quad 5 / 2)$; weathers to grayish yellow green $(5 G Y$ 7/2)

119. Siltstone, massive, dusky-yellow-green $(5 G Y 5 / 2)$; weathers to pale olive (10Y $6 / 2)$; poorly exposed.............

118. Sandstone, volcanic, thin-bedded to massive, crossbedded, fine- to mediumgrained, silty, andesitic, dusky-yellowgreen $(5 G Y 5 / 2)$; weathers to grayish yellow green $(5 G Y 7 / 2)$; slight ridge former............................

117. Claystone, massive, brownish-gray ( $5 Y R$ $4 / 1)$; weathers to light brownish gray

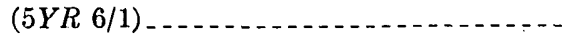

116. Sandstone, volcanic, massive, crossbedded, fine-grained, andesitic, dusky-yellowgreen ( $5 G Y 5 / 2)$; weathers to grayish yellow green $(5 G Y 7 / 2) \ldots \ldots$

115. Covered interval-probably mudstone, dusky-yellow-green. . . ..............

114. Sandstone, volcanic, thin-bedded to massive, crossbedded, fine- to mediumgrained, andesitic, dusky-yellow-green $(5 G Y 5 / 2)$; weathers to yellowish gray ( $5 Y$ $7 / 2) \ldots \ldots \ldots$. . . . . . . . . . . . . . . .

113. Sandstone, volcanic, massive, very fine grained, silty, andesitic, calcareous, dusky-yellow-green ( $5 G Y 5 / 2)$; weathers to yellowish gray $(5 Y 7 / 2) \ldots \ldots . . . . .$.

112. Sandstone, volcanic, thin-bedded to massive, crossbedded, fine- to mediumgrained, andesitic, calcareous, duskyyellow-green $(5 G Y \quad 5 / 2)$; weathers to yellowish gray $(5 Y 7 / 2)$; contains wood and plant fragments; ridge former......

111. Covered interval-probably mudstone, dusky-yellow-green....................

110. Sandstone, volcanic, thin-bedded to massive, crossbedded, fine to medium-grained, andesitic, dusky-yellow-green (5GY $5 / 2)$; weathers to a yellowish gray ( $5 Y$ $7 / 2)$; slight ridge former............

109. Mudstone, massive, grayish-brown ( $5 Y R$ $3 / 2)$; weathers to pale yellowish brown (10YR 6/2); poorly exposed..........

108. Sandstone, volcanic, thin-bedded to massive, fine- to medium-grained, poorly sorted (contains some interbedded layers composed of granules), dusky-yellowgreen $(5 G Y 5 / 2)$; weathers to yellowish gray (5Y 7/2); contains macerated plant fragments . . . . . . . . . . . . . . . . . . .

107. Covered interval-probably siltstone, brownish-gray ......................

$2 \quad 10$

12

6

186
39

1

$\begin{array}{cc}12 & 8 \\ 35 & 2\end{array}$

SECTION 18-Continued

Type section of the Billman Creek Formation of the Livingston Group, measured in the W1/2 sec. 18, T. ? S., R. 9 E., and the S12 sec. 13, T. 2 S., R. 8 E., Park County, Mont.-Continued

Upper Cretaceous-Livingston Group-Billman

Creek Formation-Continued

106. Sandstone, volcanic, massive, crossbedded, fine- to medium-grained (contains some mudstone pebbles in scour-and-fill deposits), andesitic, dusky-yellow-green $(5 G Y 5 / 2)$; weathers to grayish yellow green $(5 G Y 7 / 2)$; ridge former . . . . . . -

105. Mudstone, massive, brownish-gray ( $5 Y R$ $4 / 1$ ) ; lower $20 \mathrm{in}$. is siltstone that grades upward from the underlying sandstone; contains rare small (less than 10-in. diameter) calcareous concretions; upper $4 \mathrm{ft}$ is silty and fossiliferous, containing freshwater mollusks and gastropods; weathers to light brownish gray ( $5 Y R 6 / 1$ ); USGS Mesozoic loc. 28594; USGS Paleobotany loc. D4104-A . . . . . . . . . . . . . .

104. Sandstone, volcanic, massive, fine-grained, silty, andesitic, olive-gray ( $5 Y 3 / 2)$; contains calcareous concretions as much as $9 \mathrm{in}$. in diameter; weathers to light olive gray $(5 Y 5 / 2)$; gradational contacts with units above and below

103. Mudstone, massive, brownish-gray ( $5 Y R$ $4 / 1)$; weathers to light brownish gray (5YR 6/1); contains rare small (less than 6-in. diameter) calcareous concretions.--

102. Sandstone, volcanic, thin-bedded, very fine grained, silty, andesitic, olive-gray ( $5 Y$ $3 / 2)$; weathers to light olive gray ( $5 Y$ $5 / 2)$; gradational contacts with units above and below ..................

101. Mudstone, massive, brownish-gray ( $5 Y R$ $4 / 1)$; weathers to light brownish gray (5YR 6/1) . . . . . .

100. Covered interval-probably mudstone, brownish-gray . . . . . . . . . . . . . . . . .

Ft In.

99. Sandstone, volcanic, medium-bedded to massive, crossbedded, medium- to coarsegrained, andesitic, dusky-yellow-green ( $5 G Y 5 / 2)$; weathers to light olive gray (5Y 5/2); contains macerated plant fragments; ridge former; top $1 \mathrm{ft}$ is thin bedded and fine grained; upper $7.5 \mathrm{ft}$ is thin bedded..........................

98. Covered interval-probably mudstone,

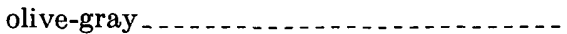

97. Sandstone, volcanic, thin-bedded, finegrained, andesitic, dusky-yellow-green ( $5 G Y 5 / 2)$; weathers to light olive gray (5Y 5/2) . . . . . . .

96. Mudstone, massive, olive-gray (5Y 3/2); weathers to light olive gray ( $5 Y 5 / 2)$;

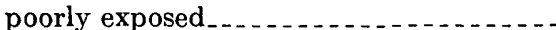

95. Sandstone, volcanic, thin-bedded to massive, crossbedded, fine- to mediumgrained, poorly sorted, dark-yellowishbrown $(10 Y R 4 / 2)$; weathers to pale

\section{0}

46

$\begin{array}{ll}70 & 11\end{array}$
1050 


\section{SECTION 18-Continued}

Type section of the Billman Creek Formation of the Livingston Group, measured in the W1/2 sec. $18, T$. 2 S., R. 9 E., and the S1/2 sec. 19, T. \& S., R. 8 E., Park County, Mont.-Continued

Upper Cretaceous-Livingston Group-Billman Creek Formation-Continued

yellowish brown $(10 Y R$ 6/2); lower $1 \mathrm{ft}$ is composed of granules and are mudstone pebbles as much as 2 in. in diameter -. -

94. Mudstone, massive, silty, dark-yellowishbrown (10YR 4/2); weathers to pale yellowish brown (10YR 6/2); poorly exposed

93. Sandstone, volcanic, massive, crossbedded, fine- to medium-grained, poorly sorted, light-brownish-gray ( $5 Y R 6 / 1)$; weathers to light olive gray $(5 Y 6 / 1)$; contains small scour-and-fill channels and bedding often marked by thin (less than $1 / 8 \mathrm{in}$.) layers of ferromagnesian minerals.......

92. Siltstone, massive, clayey, brownish-gray (5YR 4/1); weathers to light brownish gray $(5 Y R 6 / 1)$; poorly exposed.........

91. Sandstone, volcanic, massive, crossbedded, fine- to medium-grained, poorly sorted (contains some disseminated granules), andesitic, light-brownish-gray (5YR 6/1); weathers to light olive gray $(5 Y 6 / 1)$... -

90. Covered interval-probably mudstone, brownish-gray _......................

89. Sandstone, volcanic, thick-bedded, coarsegrained, poorly sorted, andesitic, olivegray ( $5 Y 4 / 1)$; weathers to brownish gray (5YR 4/1) .

88. Sandstone, volcanic, massive, crossbedded, fine-grained, andesitic, pale-yellowishbrown (10YR 6/2); weathers to light brownish gray $(5 Y R 6 / 1)$

87. Covered interval-probably mudstone, brownish-gray . ...................

86. Sandstone, volcanic, massive, crossbedded, fine-grained, andesitic, pale-yellowishbrown (10YR 6/2); weathers to light brownish gray $(5 Y R 6 / 1)$

85. Covered interval-probably mudstone,

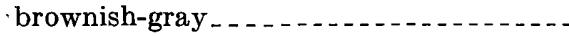

84. Sandstone, volcanic, massive, crossbedded, fine-grained, andesitic, pale-yellowishbrown $(10 Y R 6 / 2)$; has banded character imparted by very thin (less than $1 / 16$ in.) layers of ferromagnesian minerals on bedding planes; weathers to light brownish gray $(5 Y R 6 / 1)$; ridge former.........

83. Covered interval-probably mudstone, brownish-gray . . . . . . . . . . . . . . . . .

82. Sandstone, volcanic, thin-bedded to massive, crossbedded, fine-grained, andesitic, dusky-yellow-green $(5 G Y 5 / 2)$; weathers to grayish yellow green $(5 G Y 7 / 2) \ldots$

81. Mudstone, massive, brownish-gray (5YR $4 / 1)$; weathers to light brownish gray (5YR 6/1)
Ft In.

8

0

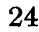

4

6

7

12

5

80

50

6

$2 \quad 2$

116

10

10

12

7

3

24
SECTION 18-Continued

Type section of the Billman Creck Formation of the Livingston Group, measured in the W1/2 sec. 18, T. 2 S., R. 9 E., and the S1/2 sec. 13, T. 2 S., R. 8 E., Park County, Mont.-Continued

Upper Cretaceous-Livingston Group-Billman Creek Formation-Continued

80. Sandstone, volcanic, medium-bedded, finegrained, andesitic, medium-light-gray (N6); weathers to light olive gray (5Y 6/1)

79. Covered interval-probably mudstone, brownish-gray

78. Sandstone, volcanic, medium-bedded, finegrained, andesitic, medium-light-gray (N6); weathers to light olive gray ( $5 Y 6 / 1)$.

77. Mudstone, massive, brownish-gray ( $5 Y R$ $4 / 1)$; weathers to light brownish gray (5YR 6/1) ..........................

76. Sandstone, volcanic, massive, crossbedded, fine-grained, andesitic, medium-light-gray (N6), has banded character imparted by thin (less than $1 / 10$ in.) layers of ferromagnesian minerals on bedding planes; weathers to light olive gray $(5 Y 6 / 1)$.....-

75. Claystone, massive, brównish-gray $(5 Y R$ $4 / 1)$; weathers to light olive gray ( $5 Y 6 / 1)$ -

74. Sandstone, volcanic, massive, medium- to coarse-grained, very poorly sorted, andesitic, medium-light-gray ( $N 6)$; weathers to light gray (N7) ................

73. Mudstone, massive, brownish-gray (5YR $4 / 1)$; weathers to light olive gray ( $5 Y 6 / 1)$; poorly exposed; USGS Paleobotany loc. D1614

72. Sandstone, volcanic, massive, medium- to coarse-grained, very poorly sorted (contains rare pebbles of volcanic rock), andesitic, medium-light-gray (N6); weathers to light gray $(N 7)$

71. Mudstone, massive, interbedded grayish-red $(5 R \quad 4 / 2)$ and grayish-green (10GY 5/2); weathers to pale red $(5 R 6 / 2)$ and grayish yellow green $(5 G Y 7 / 2)$; poorly exposed . -

70. Sandstone, volcanic, medium-bedded, very fine grained, andesitic, medium-dark-gray (N4); weathers to brownish gray ( $5 Y R$ 4/1) . . . - . -

69. Claystone, medium-bedded, very dusky red $(10 R 2 / 2)$; weathers to grayish red $(5 R$ 4/2) _..............................

68. Sandstone, volcanic, medium-bedded, very fine grained, andesitic, medium-dark-gray (N4); weathers to brownish gray (5YR

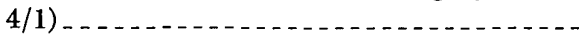

67. Claystone, medium-bedded, very dusky red $(10 R 2 / 2)$; weathers to grayish red $(5 R$ 4/2) ................................

14

$26 \quad 10$

$8 \quad 1$

50

$6 \quad 6$

$\begin{array}{ll}4 & 7\end{array}$

66. Sandstone, volcanic, massive, very fine grained, andesitic, medium-dark-gray $(N 4)$; weathers to brownish gray. ( $5 Y R$ 4/1) _..............................

65. Claystone, medium-bedded, very dusky red $(10 R 2 / 2)$; weathers to grayish red $(5 R$ $4 / 2)$
$1 \quad 11$

14

40

28 


\section{SECTION 18-Continued}

Type section of the Billman. Creek Formation of the Livingston Group, measured in the W1/2 sec. 18,T. 2 S., R. $9 \mathrm{E}$., and the S1/2 sec. 18, T. \& S., R. 8 E., Park County, Mont.-Continued

Upper Cretaceous-Livingston Group-Billman Creek Formation-Continued

64. Sandstone, volcanic, medium-bedded, very fine grained, andesitic, medium-dark-gray $(N 4)$; weathers to brownish gray $(5 Y R 4 / 1)$

63. Mudstone, massive, very dusky red $(10 R$ $2 / 2)$; weathers to grayish red $(5 R 4 / 2) \ldots$

62. Covered interval-probably mudstone, grayish-red and dusky-yellow-green..........

61. Claystone, thick-bedded, mottled duskyyellow-green $(5 G Y 5 / 2)$ and grayish-red $(5 R 4 / 2)$; weathers to grayish yellow green $(5 G Y 7 / 2)$ and pale red $(5 R 6 / 2) \ldots \ldots \ldots$

60. Sandstone, volcanic, massive, fine- to medium-grained, silty, poorly sorted, andesitic, mottled dusky-yellow-green $(5 G Y 5 / 2)$ and grayish-red $(5 R 4 / 2)$; weathers to grayish yellow green $(5 G Y \quad 7 / 2)$ and pale red $(5 R 6 / 2) \ldots \ldots$

59. Mudstone, massive, very dusky red $(10 R$ $2 / 2)$; weathers to grayish red $(5 R 4 / 2) \ldots$

58. Sandstone, volcanic, massive, crossbedded, fine- to coarse-grained, andesitic, pale-red $(5 R 6 / 2)$; weathers to light brownish gray (5YR 6/1); channel-fill deposit that cuts $13 \mathrm{ft}$ into underlying siltstone; contains rapid lateral changes in grain size and interfingers with grayish-red mudstone ..-

57. Siltstone, massive, olive-gray $(5 Y 4 / 1)$; weathers to light olive gray $(5 Y 5 / 2)$; overlying sandstone fills a channel cut $13 \mathrm{ft}$ deep into this unit ...................

56. Sandstone, volcanic, medium-bedded, finegrained, silty, andesitic, dusky-yellowgreen $(5 G Y 5 / 2)$; weathers to yellowish gray $(5 Y 7 / 2) \ldots \ldots$

55. Siltstone, thin-bedded, dusky-yellow-green $(5 G Y 5 / 2)$; weathers to light greenish gray ( $5 G Y 8 / 1)$; brecciated and cemented with' gypsum _..............................

54. Mudstone, medium-bedded, grayish-red $(10 R 4 / 2)$; weathers to pale red $(10 R 6 / 2)$..

53. Sandstone, volcanic, medium-bedded, very fine grained, andesitic, pale-red $(5 R 6 / 2)$; contains red specks of heulandite; weathers to light brownish gray ( $5 Y R 6 / 1$ ).......

52. Sandstone, volcanic, massive, finè- to coarsegrained, very poorly sorted, andesitic, pale-red $(5 R 6 / 2)$; weathers to light brownish gray (5YR 6/1); scour-and-fill deposits that contain small pebbles of mudstone and volcanic rock in lower half; generally thin bedded and fine grained in upper half .............

51. Covered interval-probably mudstone, very dusky red. . . . . . . . . . . . . . . . . .

50. Sandstone, volcanic, thin-bedded to massive, orossbedded, fine to medium-grained, poorly sorted, andesitic, calcareous, dusky-

81
SECTION 18-Continued

Type section of the Billman Creek Formation of the Iivingston Group, measured in the W1/2 sec. $18, T .2 S ., R .9 E$., and the S1/2 sec. 19, T. 2 S., R. 8 E., Park County, Mont.-Continued

Upper Cretaceous-Livingston Group-Billman Creek Formation-Continued yellow-green ( $5 G Y 5 / 2)$; weathers to dark yellowish brown $(10 Y R 4 / 2)$; ridge former --

49. Mudstone, massive, olive-gray (5Y 4/1); weathers to light olive gray (5Y 6/1); poorly exposed

48. Sandstone, volcanic, thin- to mediumbedded, fine-grained, andesitic, duskyyellow-green $(5 G Y 5 / 2)$; weathers to light olive gray $(5 Y 5 / 2) \ldots$

47. Mudstone, massive, olive-gray (5Y 4/1); weathers to light olive gray $(5 Y 6 / 1)$;

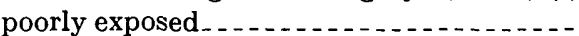

46. Sandstone, volcanic, thin- to mediumbedded, fine-grained, andesitic, duskyyellow-green $(5 G Y 5 / 2)$; weathers to light olive gray $(5 Y 5 / 2)$; ridge former........

610 45. Mudstone, massive, very dusky red (10R $2 / 2)$; weathers to grayish red $(5 R 4 / 2) \ldots$

44. Sandstone, volcanic, thin-bedded, very fine grained, silty, andesitic, olive-gray ( $5 Y$ $4 / 1)$; weathers to dark yellowish brown $(10 Y R 4 / 2)$

43. Mudstone, massive, very dusky red $(10 R$ $2 / 2)$; weathers to grayish red $(5 R 4 / 2) \ldots$

42. Sandstone, volcanic, thin-bedded, fine-grained, andesitic, medium-light-gray (N6); weathers to light gray $(N 7) \ldots \ldots$

41. Mudstone, massive, olive-gray (5Y 4/1); weathers to light olive gray $(5 Y 6 / 1) \ldots \ldots$...

264 40. Siltstone, thin-bedded, well-indurated, darkgray (N3); contains red specks of heulandite; weathers to greenish gray $(5 G Y 6 / 1)$ -

39. Siltstone, massive, olive-gray ( $5 Y$ 4/1); weathers to light olive gray ( $5 Y 6 / 1)$; contains red specks of heulandite........

38. Sandstone, volcanic, thin-bedded, finegrained, andesitic, olive-gray ( $5 Y$ 4/1); weathers to light olive gray ( $5 Y 6 / 1)$; contains abundant bronze-colored biotite.

37. Siltstone, medium-bedded, olive-gray ( $5 Y$ $4 / 1)$; weathers to light olive gray ( $5 Y 6 / 1)$; contains red specks of heulandite........

36. Sandstone, volcanic, medium- to thickbedded, crossbedded, fine-grained, andesitic, dusky-yellow-green ( $5 G Y 5 / 2)$; has banded character imparted by thin (less than $1 / 16$ in.) layers of ferromagnesian minerals on bedding planes; weathers to light olive gray ( $5 Y 5 / 2)$; contains abundant bronze-colored biotite.............

35. Claystone, massive, greenish-gray ( $5 G Y 6 / 1)$; weathers to light greenish gray ( $5 G Y 8 / 1)$ -

610 34. Sandstone, volcanic, thin-to medium-bedded, fine-grained, andesitic, dusky-yellow-green ( $5 G Y 5 / 2)$; weathers to grayish yellow green $(5 G Y 7 / 2)$; ridge former ..........

33. Siltstone, massive, olive-gray ( $5 Y$ 4/1); weathers to greenish gray $(5 G Y 6 / 1) \ldots .$.
Ft In.

$\begin{array}{ll}12 & 8\end{array}$

261

130

$48 \quad 2$

80

$\begin{array}{ll}18 & 8\end{array}$

12

$\begin{array}{ll}14 & 8\end{array}$

18

$7 \quad 10$

4

$\begin{array}{ll}7 & 4\end{array}$ 


\section{SECTION 18-Continued}

Type section of the Billman Creek Formation of the Livingston Group, measured in the $W 1 / 2$ scc. 18, T. 2 S., R. 9 E., and the S1/2 sec. 13, T. 2 S., R. 8 E., Park County, Mont.-Continued

Upper Cretaceous-Livingston Group-Billman

Creek Formation-Continued

32. Sandstone, volcanic, massive in lower half and thin- to medium-bedded in upper half, fine- to coarse-grained, poorly sorted (pebbles of volcanic rock are rare to common), dusky-yellow-green ( $5 G Y 5 / 2)$; weathers to light olive gray $(5 Y 5 / 2)$

31. Mudstone, massive, olive-gray (5Y $4 / 1)$; weathers to light olive gray $(5 Y 6 / 1)$

30. Sandstone, volcanic, massive, crossbedded, fine- to coarse-grained, poorly sorted, andesitic, dusky-yellow-green ( $5 G Y 5 / 2)$; weathers to grayish yellow green ( $5 G Y$ $7 / 2$ ); contains some calcareous concretions in the upper half

29. Covered interval-probably mudstone, dusky-yellow-green

28. Sandstone, volcanic, medium- to thickbedded, fine- to medium-grained, andesitic, dusky-yellow-green (5GY 5/2); contains abundant diopsidic augite; weathers to grayish yellow green ( $5 G Y 7 / 2)$

27. Mudstone, thick-bedded, dusky-yellow-green $(5 G Y 5 / 2)$; weathers to grayish yellow green $(5 G Y 7 / 2)$

26. Sandstone, volcanic, thin- to mediumbedded, crossbedded, fine- to coarsegrained, poorly sorted, andesitic, duskyyellow-green ( $5 G Y 5 / 2)$; weathers to grayish yellow green $(5 G Y 7 / 2)$

Ft In.

$9 \quad 2$

45

5

196

28

810

3

6

25. Mudstone, massive, brownish-gray (5YR $4 / 1$ ); weathers to light brownish gray $(5 Y R 6 / 1)$

24. Sandstone, volcanic, massive, crossbedded, fine- to medium-grained, andesitic, duskyyellow-green ( $5 G Y 5 / 2)$; weathers to grayish yellow green $(5 G Y 7 / 2)$; lower $2 \mathrm{ft}$ is poorly sorted, coarse-grained sandstone, which contains grains as large as granules; some calcareous concretions in upper $3 \mathrm{ft}$. -

23. Mudstone, massive, brownish-gray (5YR $4 / 1)$; weathers to light brownish gray $(5 Y R 6 / 1)$

22. Sandstone, volcanic, thin-bedded to massive, crossbedded, fine- to coarse-grained, poorly sorted, andesitic, grayish-green $(10 G Y 5 / 2)$; weathers to yellowish gray (5Y 7/2); contains calcareous concretions.-

21. Mudstone, massive, brownish-gray (5YR 4/1); weathers to light brownish gray (5YR 6/1)

20. Sandstone, volcanic, medium-bedded, finegrained, andesitic, medium-gray (N5); weathers to light olive gray $(5 Y 6 / 1)$

19. Mudstone, massive, brownish-gray (5YR 4/1); weathers to light brownish gray (5YR 6/1)

\section{SECTION 18 -Continued}

Type section of the Billman Creek Formation of the Livingston Group, measured in the W1/2 sec. 18, T. 2 S., R. 9 E., and the S1\%2 sec. 19, T. 2 S., R. 8 E., Park County, Mont.-Continued

Upper Cretaceous-Livingston Group-Billman

Creek Formation-Continued

Fi In.

18. Sandstone, volcanic, thin-bedded to massive, crossbedded, fine- to coarse-grained, poorly sorted, andesitic, grayish-green $(10 G Y 5 / 2)$; weathers to yellowish gray $(5 Y 7 / 2)$

17. Mudstone, massive, brownish-gray ( $5 Y R$ $4 / 1$ ); weathers to light brownish gray (5YR 6/1)

16. Sandstone, volcanic, thin-bedded to massive, crossbedded, fine- to coarse-grained, poorly sorted, andesitic, grayish-green $(10 G Y 5 / 2)$; weathers to yellowish gray $(5 Y 7 / 2)$; ridge former

15. Mudstone, massive, olive-gray (5Y 4/1); weathers to light olive gray $(5 Y 6 / 1) \ldots$

14. Sandstone, volcanic, thin-bedded to massive, crossbedded, fine-grained, andesitic, grayish-green ( $10 G Y 5 / 2)$; weathers to light olive gray ( $5 Y 5 / 2)$; contains a few calcareous concretions; ridge former ....-

13. Siltstone, massive, clayey, light-olive-gray $(5 Y 5 / 2)$; weathers to yellowish gray ( $5 Y$ $7 / 2)$

12. Sandstone, volcanic, medium-bedded, medium- to coarse-grained, andesitic, duskyyellow-green $(5 G Y \quad 5 / 2)$; weathers to yellowish gray $(5 Y 8 / 1) \ldots$

11. Siltstone, massive, moderate-olive-brown ( $5 Y$ $4 / 4)$; weathers to dusky yellow ( $5 Y 6 / 1)$

10. Sandstone, volcanic thick-bedded to massive, fine-grained, andesitic, dusky-yellowgreen $(5 G Y 5 / 2)$; weathers to yellowish gray (5Y 7/2); locally conglomeratic at base, where it contains granules and pebbles (as much as 0.5 in. in diameter) of volcanic rocks; ridge former...........

9. Siltstone, massive, moderate-olive-brown (5Y 4/4); weathers to dusky yellow (5Y

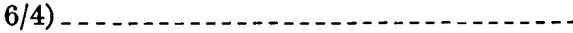

150
8. Sandstone, volcanic, massive, crossbedded, fine- to medium-grained, andesitic, medium-light-gray (N6); weathers to light gray $(N 7)$ and to very light gray $(N 8)$; slight tendency to form ridges..........

7. Mudstone, massive, light-olive-gray ( $5 Y 5 / 2)$; weathers to yellowish gray $(5 Y 7 / 2) \ldots \ldots$

6. Sandstone, volcanic, thin- to medium-bedded, fine-grained, andesitic, grayish-green $(10 G Y 5 / 2)$; contains abundant diopsidic augite; weathers to pale yellowish green (10GY 7/2) ........................

5. Claystone, massive, grayish-red $(5 R \quad 4 / 2)$; weathers to pale red $(5 R 6 / 2)$

4. Sandstone, volcanic, thin- to thick-bedded, fine- to medium-grained, andesitic, darkgreenish-gray (5GY 4/1); weathers to greenish gray (5GY 6/1); contains macerated plant fragments 


\section{SECTION 18-Continued}

Type section of the Billman Creek Formation of the Livingston Group, measured in the $W 1 / 2$ sec. 18, T. $2 S ., R .9 E .$, and the S36 sec. 18, T. \& S., R. 8 E., Park County, Mont.-Continued

Upper Cretaceous-Livingston Group-Billman Creek Formation-Continued

3. Siltstone, very thin bedded, grayish-olive (10Y 4/2); weathers to light olive gray (5Y 5/2); contains abundant macerated plant fragments

2. Sandstone, volcanic, thick-bedded to massive, crossbedded, fine- to coarse-grained, poorly sorted, andesitic, calcareous, medium-gray (N5); weathers to light olive gray (5Y $5 / 2)$; contains abundant diopsidic augite; contains abundant calcareous concretions, which are spherical (fig. 19) and persistent laterally; along some bedding planes are layers (a few inches thick) of granule and pebble conglomerate and layers of mudstone; most pebbles are mudstone but some are volcanic rock; concretions weather to grayish brown (5YR 3/2); ridge

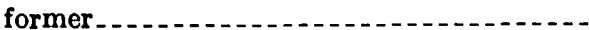

1. Mudstone, massive, grayish-brown (5YR $3 / 2$ ) and grayish-green (10GY 5/2); weathers to pale brown $(5 Y R 5 / 2)$

Total thickness of Billman Creek For-

$$
\text { mation }
$$

Upper Cretaceous-Livingston Group-Miner Creek Formation.

\section{HOPPERS FORMATION}

Stratigraphic section 19 of the Hoppers Formation of the Livingston Group, measured near Hoppers Station northeast of the abandoned townsite of Cokedale, Mont. (sections 8 and 9, fig. 15), is the type section of the formation.

\section{SECTION 19}

Type section of the Hoppers Formation of the Livingston Group, measured in the $S W 1 / 4$ sec. 7 and the $N W 1 / 4$ sec. 18, T. $2 S ., R$. 9 E., Park County, Mont.

[Measured by A. E. Roberts and A. L. Benson, 1961]

Upper Cretaceous and Paleocene-Fort Union Formation.

Upper Cretaceous-Livingston Group-Hoppers Formation:

Ft In.

52. Sandstone, volcanic, massive, crossbedded, coarse-grained, very poorly sorted, andesitic, dusky-yellow-green ( $5 G Y 5 / 2)$; weathers to light olive gray ( $5 Y 6 / 1)$ and yellowish gray ( $5 Y 7 / 2)$; cliff former . . . . .

51. Mudstone, massive, olive-gray ( $5 Y$ 4/1); weathers to light olive gray $(5 Y 6 / 1) \ldots \ldots$

50. Sandstone, volcanic, thin-bedded to massive, crossbedded, fine- to coarse-grained, poorly sorted, andesitic, dusky-yellow-green ( $5 G Y$ $5 / 2)$; weathers to light olive gray $(5 Y 6 / 1)$
SECTION 19-Continued

Type section of the Hoppers Formation of the Livingston Group, measured in the $S W 1 / 4$ sec. 7 and the NW1/4 sec. 18, T. $2 S ., R$. 9 E., Park County, Mont.-Continued

Upper Cretaceous-Livingston Group-Hoppers

Formation-Continued

Ft In.

49. Siltstone, massive, olive gray ( $5 Y$ 4/1); weathers to light olive gray $(5 Y 6 / 1) \ldots \ldots$

48. Sandstone, volcanic, thin-bedded to massive, crossbedded, fine- to coarse-grained, very poorly sorted, andesitic, dusky-yellow-green ( $5 G Y 5 / 2)$; weathers to light olive gray ( $5 Y$ $6 / 1)$; contains many layers of coarse grains to granules; contains a few layers composed of small pebbles of volcanic rock and mudstone; slight tendency to form ridges......-

47. Siltstone, massive, olive gray $(5 Y 4 / 1)$; weathers to light olive gray (5Y 6/1); poorly exposed.

46. Sandstone, volcanic, thin-bedded to massive, crossbedded, fine- to coarse-grained, poorly sorted, andesitic, dusky-yellow-green ( $5 G Y$ $5 / 2)$; weathers to light olive gray $(5 Y 6 / 1)$.-

45. Siltstone, massive, olive-gray (5Y 4/1); weathers to light olive gray $(5 Y 6 / 1)$....-

44. Sandstone, volcanic, thin-bedded to massive, crossbedded, fine- to coarse-grained, poorly sorted, andesitic, dusky-yellow-green ( $5 G Y$ $5 / 2)$; weathers to light olive gray (5Y 6/1); upper $10 \mathrm{ft}$ well-indurated.............

43. Mudstone, massive, olive-gray ( $5 Y 4 / 1)$; weathers to light olive gray ( $5 Y 6 / 1)$; poorly exposed......

42. Siltstone, massive, olive-gray (5Y 4/1); weathers to light olive gray (5Y 6/1); USGS Paleobotany loc. D4104-C.............

41. Mudstone, massive, olive-gray. (5Y 4/1); weathers to light olive gray $(5 Y 6 / 1)$

40. Sandstone, volcanic, thin-bedded to massive crossbedded, fine- to coarse-grained, poorly sorted, andesitic, dusky-yellow-green ( $5 G Y$ $5 / 2)$; weathers to greenish gray ( $5 G Y 6 / 1)$; contains wood and plant fragments........

39. Siltstone, thick-bedded, dusky-yellow-green $(5 G Y 5 / 2)$; weathers to greenish gray ( $5 G Y$ $6 / 1)$

38. Sandstone, volcanic, thin-bedded to massive, crossbedded, fine- to coarse-grained, poorly sorted, andesitic, dusky-yellow-green ( $5 G Y$ $5 / 2)$; weathers to greenish gray $(5 G Y 6 / 1)$..

37. Sandstone, thick-bedded, very fine grained, silty, dusky-yellow-green ( $5 G Y 5 / 2)$; weathers to light olive gray $(5 Y 5 / 2)$

36. Sandstone, volcanic, thin-bedded to massive crossbedded, fine- to coarse-grained, andesitic, dusky-yellow-green ( $5 G Y 5 / 2)$; weathers to light olive gray ( $5 Y 5 / 2$ ); contains wood and plant fragments; a 5-ft-thick zone in middle of unit is poorly sorted, coarse-grained to granule sandstone that contains many mudstone balls and some volcanic rock pebbles 


\section{SECTION 19-Continued}

Type section of the Hoppers Formation of the Livingston Group, measured in the $S W 1 / 4$ sec. 7 and the $N W 1 / 4$ sec. 18, T. $2 S$., $R$. 9 E., Park County, Mont.-Continued

Upper Cretaceous-Livingston Group-Hoppers Formation-Continued

35. Siltstone, thick-bedded, clayey, very calcareous (contains small calcareous concretions), brownish-black (5YR 2/1); weathers to light brownish gray ( $5 Y R$ 6/1); USGS Mesozoic loc. 28592

34. Sandstone, volcanic, thin-bedded to massive, crossbedded, fine- to coarse-grained poorly sorted, andesitic, slightly calcareous, duskyyellow-green ( $5 G Y 5 / 2)$; weathers to light olive gray $(5 Y 5 / 2)$

33. Siltstone, massive, olive-gray ( $5 Y 4 / 1)$; weathers to light olive gray $(5 Y 6 / 1) \ldots \ldots$

32. Sandstone, volcanic, thin-bedded to massive, fine- to medium-grained, andesitic, duskyyellow-green $(5 G Y 5 / 2)$; weathers to light olive gray ( $5 Y 6 / 1)$; contains wood and plant fragments

31. Mudstone, massive, olive-gray ( $5 Y$ 4/1); weathers to light olive gray $(5 Y 6 / 1)$; contains calcareous concretions............

30. Sandstone, volcanic, thin-bedded, fine- to coarse-grained, poorly sorted, andesitic, dusky-yellow-green ( $5 G Y 5 / 2)$; weathers to light olive gray ( $5 Y 6 / 1)$

29. Siltstone, medium-bedded, dusky-yellow-green ( $5 G Y 5 / 2)$; weathers to light olive gray (5Y6/1) . . . . . . . . . . . . . . . . .

28. Sandstone, volcanic, thin-bedded to massive, fine- to coarse-grained, poorly sorted, andesitic, dusky-yellow-green ( $5 G Y \quad 5 / 2)$; weathers to light olive gray ( $5 Y 6 / 1)$; contains small rare calcareous concretions; contains some petrified wood; ridge former .

27. Mudstone, massive, olive-gray ( $5 Y$ 4/1); weathers to light olive gray $(5 Y 6 / 1) \ldots \ldots$

26. Sandstone, volcanic, thin- to thick-bedded, fine- to coarse-grained, poorly sorted, andesitic, dusky-yellow-green ( $5 G Y \quad 5 / 2)$; weathers to light olive gray $(5 Y 6 / 1) \ldots$

25. Claystone, massive, olive-gray ( $5 Y$ 4/1); weathers to light olive gray $(5 Y 6 / 1) \ldots \ldots$

24. Sandstone, volcanic, thin-bedded to massive, fine- to coarse-grained, poorly sorted, andesitic, slightly calcareous, dusky-yellow-green ( $5 G Y 5 / 2)$; weathers to light olive gray (5Y 6/1) . . .

23. Mudstone, massive, olive-gray (5Y 4/1) weathers to light olive gray $(5 Y 6 / 1) \ldots \ldots$

22. Sandstone, volcanic, medium-bedded, finegrained, andesitic, dusky-yellow-green ( $5 G Y$ $5 / 2)$; weathers to light olive gray (5Y 6/1) --

21. Mudstone, massive, olive-gray (5Y 4/1); weathers to light olive gray $(5 Y 6 / 1)$

20. Sandstone, volcanic, massive, crossbedded, bedded, fine- to medium-grained, andesitic,

100

\section{SECTION 19-Continued}

Type section of the Hoppers Formation of the Livingston Group, measured in the $S W 1_{4}$ sec. 7 and the $N W 1_{4}$ sec. 18, T. $2 S$., $R$. 9 E., Park County, Mont.-Continued

Upper Cretaceous-Livingston Group-Hoppers

Formation-Continued dusky-yellow-green ( $5 G Y 5 / 2)$; weathers to light olive gray $(5 Y 6 / 1) \ldots$

19. Mudstone, massive, olive-gray (5Y 4/1); weathers to light olive gray $(5 Y 6 / 1)$; poorly exposed. . . . . . . . . . . . . . .

18. Sandstone, volcanic, thin-bedded to massive, fine- to coarse-grained, poorly sorted, andesitic, dusky-yellow-green $(5 G Y 5 / 2)$; weathers to light olive gray $(5 Y 5 / 2)$

17. Mudstone, massive, olive-gray (5Y 4/1); weathers to light olive gray $(5 Y 6 / 1) \ldots \ldots$....

16. Sandstone, volcanic, thin-bedded, very fine grained, silty, andesitic, dusky-yellow-green (5GY 5/2); weathers to light olive gray (5Y 5/2) . . . . . .

15. Siltstone, thick-bedded, olive-gray $(5 Y 4 / 1)$; weathers to light olive gray $(5 Y 6 / 1) \ldots . . .$.

14. Sandstone, volcanic, thin-bedded to massive, crossbedded, fine-grained, andesitic, calcareous, dusky-yellow-green $(5 G Y \quad 5 / 2)$; weathers to light olive gray $(5 Y 5 / 2)$; ridge former.

13. Mudstone, massive, olive-gray (5Y 4/1); weathers to light olive gray $(5 Y 6 / 1)$; poorly exposed.

Ft In.

124

$30 \quad 0$

$29 \quad 2$

$\begin{array}{ll}7 & 11\end{array}$

150

12. Sandstone, volcanic, thin-bedded, crossbedded, fine-grained, andesitic, dusky-yellow-green (5GY $5 / 2$ ); weathers to light olive gray ( $5 Y$ $5 / 2)$; poorly exposed. .................

11. Mudstone, massive, olive-gray (5Y 4/1); weathers to light olive gray $(5 Y 6 / 1)$; poorly exposed

Total Hoppers Formation that lies above the basal sandstone member

Basal sandstone member:

10. Sandstone, volcanic, thin-bedded to massive, crossbedded, fine- to coarse-grained, very poorly sorted (contains thin to medium conglomeratic beds composed of small mudstone pebbles), andesitic, calcareous, duskyyellow-green $(5 G Y \quad 5 / 2)$; weathers to a conspicuous yellowish gray $(5 Y 7 / 2)$ : has banded character imparted by thin (less than 0.25 in.) layers of ferromagnesian minerals on bedding planes; large massive speroidal weathering; thin-bedded part is finer grained and commonly more calcareous then rest of unit, and it is commonly cut out by the overlying massive sandstone; cliff former; contains some wood and plant imprints . . . . . . . . . . . . . . . . . . . . . .

9. Mudstone, thick-bedded, olive-gray ( $5 Y 4 / 1)$; weathers to light olive gray $(5 Y 6 / 1) \ldots \ldots$
746 


\section{SECTION 19-Continued}

Type section of the Hoppers Formation of the Livingston Group, measured in the $S W 1 / 4$ sec. 7 and the $N W 1 / 4$ sec. 18, T. 2. S., R. 9:E.; Park County, Mont.-Continued

Upper Cretaceous-Livingston Group-Hoppers Formation-Continued

Basal sandstone member-Continued

8. Sandstone, volcanic, thin-bedded, fine- to medium-grained, andesitic, calcareous, duskyyellow-green ( $5 G Y 5 / 2)$; weathers to yellowish gray $(5 Y 7 / 2)$

7. Siltstone, thick-bedded, clayey, dusky-yellowgreen $(5 G Y 5 / 2)$; weathers to light olive gray $(5 Y 5 / 2)$

6. Sandstone, volcanic, thin-bedded, fine- to medium-grained, andesitic, calcareous, duskyyellow-green ( $5 G Y 5 / 2)$; weathers to yellowish gray $(5 Y 7 / 2)$

5. Claystone, thick-bedded, olive-gray ( $5 Y$ 4/1); weathers to light olive gray $(5 Y 6 / 1)$......-.-

4. Sandstone, volcanic, thin-bedded, fine- to medium-grained, andesitic, calcareous, duskyyellow-green $(5 G Y 5 / 2)$; weathers to yellowish gray (5Y 7/2); eastward this unit merges with the underlying sandstone unit.........

3. Sandstone, volcanic, massive, crossbedded, very poorly sorted, andesitic, slightly calcareous, dusky-yellow-green ( $5 G Y 5 / 2)$; weathers to yellowish gray ( $5 Y 7 / 2)$; composed of coarse grains to granules; locally conglomeratic, containing small mudstone pebbles; ridge former . . . . . . . . . . .

2. Mudstone, thick-bedded, olive-gray (5Y 4/1); weathers to light olive gray $(5 Y 6 / 1)$; contains a few calcareous concretions; this unit is cut out to the east, where the overlying and underlying sandstones form a large cliff .....

1. Sandstone, volcanic, massive, crossbedded, thinbedded locally in upper part, fine-grained, andesitic, slightly calcareous in upper part, dusky-yellow-green $(5 G Y 5 / 2)$; weathers to yellowish gray $(5 Y 7 / 2)$; contains rare mudstone balls in lower part._._.

Total thickness of basal sandstone member $142 \quad 0$

Total thickness of Hoppers Formation _... 965 Upper Cretaceous-Livingston group-Billman Creek Formation.

\section{FORT UNION FORMATION}

Stratigraphic section 20 of the Fort Union Formation is considered to be typical of the formation in the area west of Livingston and is here designated a reference section. This section was measured north of Hoppers Station near the abandoned townsite of Cokedale, Mont. (sections 10-18, fig. 15). The section at this locality is the most complete (contains the youngest beds of the formation in the western part of the Crazy Mountains basin).

\section{SECTION 20}

Reference section of the Fort Union Formation, measured in secs. 7, $16,17,21,28,92$, and $39, T .1$ S., R. 8 E.; secs. \&, 3, 11, 12 13 , and $23, T . \mathscr{Q} S ., R .8 E$.; and secs. $7,18,19$, and $20, T . \mathscr{Q} S$., R. 9 E., Park County, Mont.

[Messured by A. E. Roberts and A. L. Benson, 1961]

Paleocene-Fort Union Formation:

Topmost section of formation removed by erosion. Upper conglomeratic sandstone member:

242. Sandstone, volcanic, thin-bedded to massive, crossbedded, fine- to medium-grained, andesitic, calcareous, greenish-gray (5GY 6/1); weathers to grayish yellow green ( $5 G Y 7 / 2)$; commonly contains pebbles of volcanic rock, quartzite, gneiss, and limestone; contains wood and plant fragments; ridge former.........

241. Covered interval-probably siltstone, similar to underlying unit.........

240. Siltstone, thin-bedded to massive, sandy, locally calcareous, light-olivegray $(5 Y 5 / 2)$; weathers to yellowish gray (5Y 7/2); contains abundant calcareous concretions less than $1 \mathrm{ft}$ in diameter.

239. Sandstone, volcanic, thin-bedded to massive, crossbedded, fine- to coarsegrained (commonly contains pebbles of volcanic rock, quartzite, gneiss, and limestone), andesitic, calcareous, greenish-gray (5GY 6/1); weathers to grayish yellow green ( $5 G Y 7 / 2)$; contains a few interbedded very fine grained silty sandstones; contains wood and plant fragments; ridge former. . . . . . . . . .

238. Sandstone, volcanic, thin-bedded, finegrained, andesitic, light-olive-gray (5Y 5/2); weathers to light olive gray ( $5 Y 6 / 1)$; contains rare volcanic rock pebbles; contains wood and plant fragments; ridge former. .....

237. Sandstone, volcanic, thin-bedded, very fine grained, silty, andesitic, lightolive-gray ( $5 Y \quad 5 / 2)$; weathers to light olive gray ( $5 Y 6 / 1)$; contains a few calcareous concretions as much as 6 in. in diameter (generally 2 in.); grades upward into siltstone in upper part; poorly exposed...............

236. Sandstone, volcanic, thin-bedded to massive, crossbedded, fine-grained, andesitic, calcareous, greenish-gray ( $5 G Y 6 / 1)$; weathers to grayish yellow green ( $5 G Y 7 / 2)$; contains a few sporadic pebbles of volcanic rock; contains wood and plant fragments; ridge former 


\section{SECTION 20-Continued}

Reference section of the Fort Union Formation, measured in secs. 7, 16, 17, 21, 28, 32, and 33, T. 1 S., R. 8 E.; secs. 2, 3, 11, 12, 13, and 23, T. 2 S., R. 8 E.; and secs. 7, 18, 19, and 20, T. 2 S., R. 9 E., Park County, Mont.-Continued

Paleocene-Fort Union Formation-Continued Upper conglomeratic sandstone member-Con. 235. Sandstone, volcanic, thin-bedded, very fine grained, silty, andesitic, noncalcareous, light-olive-gray ( $5 Y 5 / 2)$; weathers to light olive gray $(5 Y 6 / 1)$; poorly exposed...-.

234. Sandstone, volcanic, thin-bedded to massive, crossbedded, fine-grained, andesitic, calcareous, greenish-gray ( $5 G Y 6 / 1$ ); weathers to grayish yellow green ( $5 G Y 7 / 2$ ); contains wood and plant fragments; ridge former.-

233. Sandstone, volcanic, thin-bedded, very fine grained, silty, andesitic, noncalcareous, light-olive-gray ( $5 Y 5 / 2$ ); weathers to light olive gray $(5 Y$ 6/1); poorly exposed . . ...........

232. Sandstone, volcanic, massive, fine- to medium-grained, andesitic, calcareous, greenish-gray ( $5 G Y \quad 6 / 1)$; weathers to grayish yellow green ( $5 G Y 7 / 2)$; contains rare pebbles of volcanic rock; contains wood and plant fragments.

231. Covered interval-probably very fine grained noncalcareous sandstone - -

230. Sandstone, volcanic, thin-bedded, fineto coarse-grained, andesitic, calcareous, greenish-gray ( $5 G Y \quad 6 / 1)$; weathers to grayish yellow green ( $5 G Y 7 / 2)$; ridge former

229. Covered interval-probably very fine grained sandstone

228. Sandstone, volcanic, thin-bedded, fineto coarse-grained, andesitic, calcareous, greenish-gray ( $5 G Y \quad 6 / 1)$; weathers to grayish yellow green $(5 G Y 7 / 2)$; poorly exposed in upper part.............................

227. Covered interval-probably very fine grained sandstone...............

226. Sandstone, volcanic, thin-bedded, fineto coarse-grained, andesitic, calcareous, greenish-gray ( $5 G Y \quad 6 / 1)$; weathers to grayish yellow green ( $5 G Y 7 / 2)$; contains interbedded very fine grained silty sandstone; slight tendency to form ridges............

225. Sandstone, volcanic, thin-bedded, very fine grained, silty, andesitic, light-olive-gray ( $5 Y \quad 5 / 2)$; weathers to light olive gray (5Y 6/1); poorly exposed.

224. Sandstone, volcanic, thin-bedded, crossbedded, fine- to coarse-grained, andesitic; contains sporadic pebbles and cobbles of volcanic rock, granite,

\section{SECTION 20-Continued}

Reference section of the Fort Union Formation, measured in secs. 7 , 16, 17, 21, 28, 32, and 33, T. 1 S., R. 8 E.; secs. 2, 3, 11, 12, 13, and 23, T. 2 S., R. 8 E.; and secs. 7, 18, 19, and 20, T. $2 S$., R. 9 E., Park County, Mont.-Continued

Paleocene-Fort Union Formation-Continued Upper conglomeratic sandstone member-Con. quartzite, welded tuff, and clay; calcareous in upper $10 \mathrm{ft}$.; greenishgray ( $5 G Y 6 / 1)$; weathers to grayish yellow green $(5 G Y 7 / 2)$; contains wood and plant fragments; slight tendency to form ridges..........

223. Sandstone, volcanic, thin-bedded to massive, crossbedded, fine- to coarsegrained, andesitic, locally calcareous, greenish-gray ( $5 G Y$ 6/1); weathers to grayish yellow green $(5 G Y 7 / 2)$; contains interbedded fine-grained silty sandstone...................

222. Sandstone, volcanic, thin-bedded to massive, crossbedded, fine- to coarsegrained, andesitic, locally calcareous, greenish-gray ( $5 G Y 6 / 1)$; weathers to grayish yellow green ( $5 G Y 7 / 2)$; locally contains layers-generally at the bottom of a channel deposit-of pebbles and cobbles of volcanic rock, quartzite, and gneiss; contains wood and plant fragments; very calcareous continuously in upper 20 ft., which makes it a very good ridge former.

1116

221. Sandstone, volcanic, thin-bedded, very fine grained, silty, andesitic, lightolive-gray $(5 Y \quad 5 / 2)$; weathers to light olive gray $(5 Y 6 / 1) \ldots$
36
20. Sandstone, volcanic, thin-bedded to massive (generally thin-bedded), crossbedded, fine-grained, andesitic, calcareous, greenish-gray (5GY 6/1); weathers to grayish yellow green (5GY $7 / 2)$; slight tendency to form ridges............................

219. Covered interval-probably very fine grained sandstone. . . . . . . . . . . . .

218. Sandstone, volcanic, thin-bedded to massive, crossbedded, fine- to coarsegrained, poorly sorted (commonly contains pebbles and cobbles of volcanic rock, quartzite, and gneiss), andesitic, greenish-gray ( $5 G Y$ 6/1); weathers to grayish yellow green (5GY 7/2) ; poorly exposed..........

217. Covered interval-probably very fine grained sandstone................

216. Sandstone, volcanic, thin-bedded to massive (generally thin-bedded), crossbedded, fine-grained, andesitic, calcareous, greenish-gray ( $5 G Y 6 / 1)$; weathers to grayish yellow green (5GY 7/2); slight tendency to form ridges_._.
Ft In.

$66 \quad 0$

640

$\begin{array}{ll}8 & 2\end{array}$

$18 \quad 4$

$29 \quad 6$

$34 \quad 6$

220

316 


\section{SECTION 20-Continued}

Reference section of the Fort Union Formation, measured in secs. 7, $16,17,21,28,32$, and $39, T .1$ S., R. 8 E.; secs. $2,3,11,12$, 13 , and $23, T .2 S ., R .8$ E.; and secs. 7, 18, 19, and $20, T$. $2 S$., R. 9 E., Park County, Mont.-Continued

Paleocene-Fort Union Formation-Continued Upper conglomeratic sandstone member-Con.

215. Covered interval-probably very fine grained sandstone...............

214. Sandstone, volcanic, thin-bedded to massive (generally thin-bedded), crossbedded, fine-grained, andesitic, calcareous, greenish-gray ( $5 G Y 6 / 1)$; weathers to grayish yellow green (5GY 7/2); slight tendency to form ridges...........................

213. Covered interval-probably very fine grained sandstone

212. Sandstone, volcanic, thin-bedded to massive (generally thin-bedded), crossbedded, fine-grained, andesitic, calcareous, greenish-gray ( $5 G Y 6 / 1$ ); weathers to grayish yellow green (5GY 7/2) slight tendency to form ridges..........................

211. Covered interval-probably very fine grained sandstone................

210. Sandstone, volcanic, thin-bedded to massive, crossbedded, fine- to coarse-grained, slightly calcareous, greenish-gray ( $5 G Y$ 6/1); weathers to grayish yellow green ( $5 G Y 7 / 2)$..

209. Covered interval-probably very fine grained sandstone................

208. Sandstone, volcanic, thin-bedded to massive, crossbedded, fine- to coarse-grained, andesitic, slightly calcareous, greenish-gray ( $5 G Y 6 / 1)$; weathers to grayish yellow green (5GY 7/2)

207. Sandstone, volcanic, thin-bedded very fine grained, silty, andesitic light-olive-gray (5Y 5/2); weathers to. light olive gray $(5 Y 6 / 1)$; poorly exposed.......................

206. Sandstone, volcanic, thin-bedded, finegrained, andesitic, greenish-gray (5GY 6/1); weathers to grayish yellow green $(5 G Y 7 / 2) \ldots . . . . . . . . . .$.

205. Sandstone, volcanic, thin-bedded to massive, crossbedded, fine- to coarsegrained, andesitic, locally, calcareous greenish-gray ( $5 G Y 6 / 1)$; weathers to grayish yellow green (5GY 7/2); contains sporadic pebbles, cobbles, and boulders of volcanic rock, quartzite, and gneiss; poorly exposed.....-

204. Sandstone, volcanic, thin-bedded to massive, crossbedded, fine- to coarsegrained, andesitic, slightly calcareous, greenish-gray ( $5 G Y 6 / 1)$; weathers to grayish yellow green ( $5 G Y$ $7 / 2)$; slight tendency to form ridges.-

\section{SEGTION 20-Continued}

Reference section of the Fort Union Formation, measured in secs. 7, $16,17,21,28,32$, and $38, T .1$ S., R. 8 E.; secs. $2,3,11,12$, 19, and $28, T .2 S .$, R. 8 E.; and secs. $7,18,19$, and $20, T .2 S$., R. 9 E., Park County, Mont.-Continued

Paleocene-Fort Union Formation-Continued

Upper conglomeratic sandstone member-Con.

203. Sandstone, volcanic, thin-bedded, very fine grained, silty, andesitic, lightolive-gray ( $5 Y 5 / 2)$; weathers to light olive gray $(5 Y$ 6/1); poorly exposed.........................

202. Sandstone, volcanic, thin-bedded to massive, crossbedded, fine- to coarsegrained, andesitic, slightly calcare-

\begin{tabular}{cc|r}
38 & 6 & $\begin{array}{r}\text { ous, greenish-gray (5GY 6/1); weath- } \\
\text { ers to grayish yellow green (5GY 7/2)- }\end{array}$ \\
31 & 0 & 201. Claystone, thick-bedded, olive-gray
\end{tabular}

\begin{tabular}{cc|r}
38 & 6 & $\begin{array}{r}\text { ous, greenish-gray (5GY 6/1); weath- } \\
\text { ers to grayish yellow green (5GY 7/2)- }\end{array}$ \\
31 & 0 & 201. Claystone, thick-bedded, olive-gray
\end{tabular} (5Y 4/1); weathers to light olive gray $(5 Y 6 / 1)$

200. Sandstone, volcanic, thin-bedded, very fine grained, silty, andesitic, lightolive-gray ( $5 \hat{Y} 5 / 2)$; weathers to light olive gray $(5 Y 6 / 1)$

217
23

49

$17 \quad 4$

140

240

10
199. Sandstone, volcanic, thin-bedded to massive, crossbedded, fine- to coarsegrained, andesitic, calcareous, greenish-gray $(5 G Y$ 6/1); weathers to grayish yellow green (5GY 7/2); contains pebbles, cobbles, and boulders of volcanic rock, quartzite, and gneiss-generally along the base of channel deposits; ridge former......

Total measured upper conglomeratic sandstone member...... 1,800 0

Middle sandstone and mudstone member:

198. Covered interval-probably yellowishgray siltstone....................

197. Sandstone, volcanic, thin-bedded to massive (dominantly thin-bedded and fine-grained), fine- to coarse-grained (contains sporadic pebbles of volcanic rock and mudstone), andesitic, calcareous, greenish-gray ( $5 G Y 6 / 1)$; weathers to grayish yellow green $(5 G Y 7 / 2)$; cliff former............

196. Siltstone, massive, clayey, grayishgreen ( $5 G Y 6 / 1)$; weathers to light olive gray (5Y 6/1); contains macerated plant fragments.............

195. Sandstone, volcanic, thin-bedded to massive (dominantly thin-bedded and fine-grained), fine- to coarsegrained, andesitic, slightly calcareous, greenish-gray ( $5 G Y 6 / 1)$; weathers to grayish yellow green ( $5 G Y$ $7 / 2$ ); contains layers of mudstone pebbles.........................

194. Mudstone, massive, olive-gray (5Y 4/1); weathers to light olive gray $(5 Y 6 / 1)$; poorly exposed. 


\section{SECTION 20-Continued}

Reference section of the Fort Union Formation, measured in secs. 7 , 16, 17, 21, 28, 32, and 39, T. 1 S., R. 8 E.; secs. 2, 3, 11, 12, 13, and 23, T. Q S., R. 8 E.; and secs. 7, 18, 19, and 20, T. $2 S$., R. 9 E., Park County, Mont.-Continued

Paleocene-Fort Union Formation-Continued Middle sandstone and mudstone member-Con. 193. Sandstone, volcanic, thin-bedded to massive, fine- to coarse-grained (dominantly thin-bedded and finegrained), andesitic, slightly calcareous, greenish-gray $(5 G Y 6 / 1)$; weathers to grayish yellow green ( $5 G Y$ $7 / 2)$

192. Mudstone, massive, olive-gray (5Y $4 / 1)$; weathers to light olive gray (5Y 6/1); poorly exposed.........

191. Sandstone, volcanic, thin-bedded to massive, fine- to coarse-grained (dominantly fine-grained and thinbedded), andesitic, slightly calcareous, greenish-gray ( $5 G Y 6 / 1)$; weathers to grayish yellow green ( $5 G Y$ $7 / 2)$; ridge former.

190. Sandstone, volcanic, massive, very fine grained, silty, andesitic, greenishgray ( $5 G Y 6 / 1)$; weathers to grayish yellow green $(5 G Y 7 / 2)$; very poorly exposed

189. Sandstone, volcanic, massive, crossbedded, medium- to coarse-grained, andesitic, slightly calcareous, greenish-gray ( $5 G Y 6 / 1)$; weathers to grayish yellow green $(5 G Y 7 / 2) \ldots \ldots . . .$.

188. Sandstone, volcanic, thin-bedded, crossbedded, fine-grained, andesitic, slightly calcareous, greenish-gray $(5 G Y 6 / 1)$; weathers to grayish yellow green ( $5 G Y 7 / 2)$; slight ridge former.

187. Claystone, medium-bedded, olive-gray (5Y 4/1); weathers to light olive gray $(5 Y 6 / 1)$

186. Sandstone, volcanic, thin-bedded to massive, crossbedded, fine- to coarsegrained (dominantly thin-bedded and fine-grained), andesitic, slightly calcareous, greenish-gray ( $5 G Y 6 / 1)$; weathers to grayish yellow green (5GY 7/2)

185. Covered interval-probably mudstone that has about $10 \mathrm{ft}$ of thin-bedded, medium-grained sandstone in the middle

184. Sandstone, volcanic, thin-bedded to massive, crossbedded, fine- to coarsegrained, andesitic, greenish-gray $(5 G Y 6 / 11)$; weathers to grayish yellow green ( $5 G Y 7 / 2)$; slight tendency to form ridges...............

183. Claystone, massive, olive-gray ( $5 Y$ $4 / 1)$; weathers to light olive gray (5Y 6/1); poorly exposed.

Fi In.
25

Paleocene-Fort Union Formation-Continued

Middle sandstone and mudstone member-Con.

182. Sandstone, volcanic, thin-bedded, cross-bedded, fine- to coarse-grained, andesitic, slightly calcareous, greenish-gray ( $5 G Y$ 6/1); weathers to grayish yellow green ( $5 G Y 7 / 2)$

181. Covered interval-probably massive olive-gray mudstone..............

Reference section of the Fort Union Formation, measured in secs. 7 , 16, 17, 21, 28, 32, and 38, T. 1 S., R. 8 E.; secs. 2, 3, 11, 12, 13, and $23, T .2 S ., R .8 E$.; and secs. $7,18,19$, and $20, T .2 S$., R. 9 E., Park County, Mont.-Continued

180. Sandstone, volcanic, thin-bedded to massive, crossbedded, fine- to coarsegrained, andesitic, slightly calcareous, greenish-gray $(5 G Y \quad 6 / 1)$; weathers to grayish yellow green $(5 G Y 7 / 2)$; ridge former.........

179. Mudstone, massive, olive-gray ( $5 Y$ $4 / 1)$; weathers to light olive gray (5Y 6/1); poorly exposed........

178. Sandstone, volcanic, thin-bedded to massive, crossbedded, fine- to coarsegrained, andesitic, slightly calcareous, greenish-gray $(5 G Y \quad 6 / 1)$; weathers to grayish yellow green (5GY 7/2); contains local zones of mudstone pebbles; contains wood and plant fragments; ridge former--

177. Sandstone, volcanic, massive, very fine grained, silty, andesitic, micaceous, greenish-gray ( $5 G Y 6 / 1)$; weathers to light olive gray ( $5 G Y 6 / 1)$; contains macerated plant fragments; poorly exposed...........

176. Claystone, massive, olive-gray (5Y $4 / 1$ ); weathers to light olive gray $(5 Y 6 / 1)$; contains dark-olive-gray (5Y 3/1) calcareous concretions as much as 6 in. in diameter; poorly exposed.........................

175. Sandstone, volcanic, thin-bedded to massive, crossbedded, fine- to coarsegrained, andesitic; contains local zones of mudstone pebbles; slightly calcareous; greenish-gray ( $5 G Y 6 / 1)$; weathers to grayish yellow green (5GY 7/2); contains wood and plant fragments; ridge former.........

174. Sandstone, volcanic, massive, very fine grained, silty, andesitic, greenishgray ( $5 G Y 6 / 1)$; weathers to light olive gray $(5 Y 6 / 1)$

120

900

173. Sandstone, volcanic, thin-bedded to massive, crossbedded, fine- to coarsegrained, andesitic; contains local zones of mudstone pebbles; slightly calcareous; greenish-gray ( $5 G Y 6 / 1)$; weathers to grayish yellow green ( $5 G Y 7 / 2)$; contains wood and plant fragments; ridge former.......... 


\section{SECTION 20-Continued}

Reference section of the Fort Union Formation, measured in secs. 7; $16,17,21,28,32$, and $99, T$. 1 S., R. 8 E.; secs. $2,3,11,12$, 13 , and $23, T . \&$ S., R. 8 E.; and secs. $7,18,19$, and $20, T .2 S$. , R. 9 E., Park County, Mont.-Continued

Paleocene-Fort Union Formation-Continued Middle sandstone and mudstone member-Con.

172. Siltstone, massive, sandy, greenishgray $(5 G Y 6 / 1) ;$ 'weathers to light olive gray $(5 Y 6 / 1)$

171. Mudstone, massive, olive-gray ( $5 Y$ $4 / 1)$; weathers to light olive gray (5Y 6/1)

170. Sandstone, volcanic, massive, very fine grained, silty, andesitic, greenish-gray (5GY 6/1); weathers to light olive gray ( $5 Y$ 6/1); grades upward into the overlying mudstone. -

169. Mudstone, thick-bedded, olive-gray (5Y 4/1); weathers to light olive gray $(5 Y 6 / 1) \ldots$

168. Sandstone, volcanic, massive, fine- to coarse-grained, andesitic, calcareous in middle, greenish-gray ( $5 G Y 6 / 1)$; weathers to grayish yellow green (5GY 7/2) . . . . . . . . . . . . . . .

167. Mudstone, massive, olive-gray (5Y $4 / 1)$; weathers to light olive gray (5Y 6/1) . . . . . . . .

166. Sandstone, volcanic, massive, very fine grained, silty, andesitic, calcareous in upper $2 \mathrm{ft}$., greenish-gray (5GY 6/1); weathers to light olive gray $(5 Y 6 / 1) \ldots \ldots$

165. Mudstone, massive, calcareous, olivegray $(5 Y 4 / 1)$; weathers to light olive gray $(5 Y 6 / 1) \ldots$

164. Sandstone, volcanic, thick-bedded, very fine grained, silty, andesitic, calcareous, greenish-gray ( $5 G Y 6 / 1)$; weathers to light olive gray $(5 Y 6 / 1)$.

163. Siltstone, medium-bedded, greenishgray $(5 G Y 6 / 1)$; weathers to light olive gray (5Y 6/1)

162. Limestone, dense, microcrystalline, medium-gray (N5); weathers to light olive gray (5Y 6/1); probably of fresh-water origin

161. Mudstone, massive, calcareous, olivegray ( $5 Y$ 4/1); weathers to light olive gray ( $5 Y 6 / 1)$; contains calcareous concretions as much as 8 in. in diameter.

160. Siltstone, thick-bedded, greenish-gray ( $5 G Y$ 6/1); weathers to light olive gray $(5 Y 6 / 1)$

159. Sandstone, volcanic, thick-bedded, very fine grained, silty, andesitic, greenish-gray ( $5 G Y \quad 6 / 1)$; weathers to light olive gray ( $5 Y 6 / 1)$; gradational into overlying siltstone......

158. Sandstone, volcanic, thin-bedded, finegrained, andesitic, very calcareous, greenish-gray ( $5 G Y 6 / 1)$; weathers
SECTION 20-Continued

Reference section of the Fort Union Formation, measured in secs. 7 , 16, 17, 21, 28, 32, and 39, T. 1 S., R. 8 E.; secs. 2, 3, 11, 12, 13, and 23, T. $2 S ., R .8$ E.; and secs. 7, 18, 19, and 20, T. $2 S$., R. 9 E., Park County, Mont.-Continued

Paleocene-Fort Union Formation-Continued

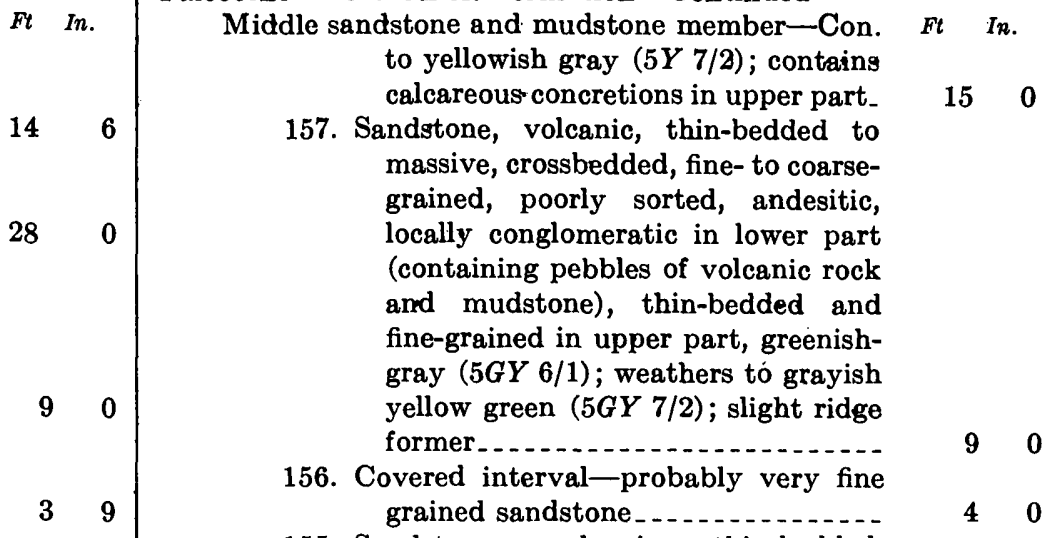

155. Sandstone, volcanic, thin-bedded, slightly crossbedded, fine- to coarsegrained, andesitic, calcareous, greenish-gray (5GY 6/1); weathers to grayish yellow green $(5 G Y 7 / 2)$; contains wood fragments; slight tendency to form ridges............

154. Sandstone, volcanic, thin-bedded to massive, crossbedded, fine- to coarse-grained. andesitic, slightly calcareous, greenish-gray ( $5 G Y 6 / 1$ ); weathers to grayish yellow green ( $5 G Y 7 / 2$ ); slight tendency to form ridges

153. Sandstone, volcanic, massive, very fine grained, silty, andesitic, greenish-gray ( $5 G Y$ 6/1); weathers to light olive gray $(5 Y 6 / 1) \ldots \ldots$

152. Sandstone, volcanic, thin-bedded to massive, crossbedded, fine- to coarse-grained (coarse in lower part grading upward to fine), andesitic, slightly calcareous, greenish-gray (5GY 6/1); weathers to grayish yellow green $(5 G Y 7 / 2)$.

151. Sandstone, volcanic, thin-bedded to massive, crossbedded, fine- to medium-grained, andesitic, slightly calcareous, greenish-gray ( $5 G Y 6 / 1)$; weathers to grayish yellow green ( $5 G Y 7 / 2)$; slight tendency to form

122 150. Covered interval-probably very fine grained sandstone.

20 149. Sandstone, volcanic, medium-bodded, fine-grained, andesitic, slightly calcareous, greenish-gray $(5 G Y 6 / 1)$; weathers to grayish yellow green (5GY 7/2) . . . . . . . . . . . . . ndstone, volcanic, massive, very fine grained, silty, andesitic, greenishgray ( $5 G Y 6 / 1)$; weathers to light olive gray $(5 Y 6 / 1)$
450 


\section{SECTION 20-Continued}

Reference section of the Fort Union Formation, measured in secs. 7 , 16, 17, 21, 28, 32, and 33, T. 1 S., R. 8 E.; secs. $2,3,11,12$, 13, and 23, T. 2 S., R. 8 E.; and secs. $7,18,19$, and $20, T .2 S$. , R. 9 E., Park County, Mont.-Continued

Paleocene-Fort Union Formation-Continued

Middle sandstone and mudstone member-Con. Ft In.

147. Sandstone, volcanic, thin-bedded to massive, crossbedded, fine- to medium-grained, andesitic, slightly calcareous in upper part; greenish-gray $(5 G Y 6 / 1)$; weathers to grayish yellow green $(5 G Y 7 / 2)$ in upper part and yellowish gray $(5 Y 7 / 2)$ in lower part; ridge former ............

146. Sandstone, volcanic, thick-bedded, very fine grained, silty, andesitic, greenish-gray $(5 G Y 6 / 1)$; weathers to light olive gray $(5 Y 6 / 1)$; contains macerated plant fragments . . . . . . . -

145. Sandstone, volcanic, medium-bedded, fine-grained, andesitic, calcareous, greenish-gray ( $5 G Y 6 / 1)$; weathers to grayish yellow green $(5 G Y 7 / 2)$..

144. Sandstone, volcanic, massive, finegrained, andesitic, greenish-gray (5 $G Y 6 / 1)$; weathers to light olive gray (5Y 6/1); contains macerated plant fragments.

143. Sandstone, volcanic, thin- to thickbedded, crossbedded, fine- to coarsegrained, andesitic, slightly calcareous, greenish-gray (5GY 6/1); weathers to grayish yellow green ( $5 G Y 7 / 2)$; slight tendency to form ridges....

142. Sandstone, volcanic, massive, very fine grained, silty, andesitic, greenish-gray ( $5 G Y 6 / 1)$; weathers to light olive gray $(5 Y 6 / 1)$

141. Sandstone, volcanic, thin-bedded to massive, crossbedded, fine- to coarsegrained, andesitic, slightly calcareous, greenish-gray ( $5 G Y$ 6/1); weathers to grayish yellow green (5GY 7/2); ridge former...........

140. Sandstone, volcanic, massive, very fine grained, silty, andesitic, greenishgray ( $5 G Y 6 / 1)$; weathers to light olive gray (5Y 6/1); poorly exposed.

139. Mudstone, massive, olive-gray (5Y $4 / 1)$; weathers to light olive gray (5Y 6/1); poorly exposed.........

138. Sandstone, volcanic, thin-bedded to massive, crossbedded, fine- to coarsegrained, andesitic, slightly calcareous, greenish-gray (5GY 6/1); weathers to grayish yellow green (5GY 7/2); upper part thin bedded; contains wood fragments; ridge former
Paleocene-Fort Union Formation-Continued

Middle sandstone and mudstone member-Con.

137. Sandstone, volcanic, massive, very fine grained, silty, andesitic, greenishgray ( $5 G Y 6 / 1)$; weathers to light olive gray $(5 Y 6 / 1)$; poorly exposed.

136. Mudstone, massive, olive-gray ( $5 Y$ $4 / 1)$; weathers to light olive gray (5Y 6/1); poorly exposed..........
260 2

(1)

18

15 0

$4 \quad 4$

6

8

0
Reference section of the Fort Union Formation, measured in secs. 7 , $16,17,21,28,32$, and $33, T .1$ S., R. 8 E.; secs. 2, 3, 11, 12, 13, and $23, T .2 S ., R .8 E$.; and secs. 7, 18, 19, and 20, T. 2 S., R. 9 E., Park County, Mont.-Continued ndstone, volcanic, thin-bedded, slightly crossbedded, fine-grained, andesitic, slightly calcareous, greenish-gray ( $5 G Y 6 / 1)$; weathers to light olive gray $(5 Y 6 / 1)$

134. Sandstone, volcanic, thick-bedded, very fine grained, silty, andesitic, greenish-gray ( $5 G Y 6 / 1)$; weathers to light olive gray $(5 Y 6 / 1)$

133. Sandstone, volcanic, thin-bedded to massive, fine- to medium-grained, andesitic, slightly calcareous, greenish-gray ( $5 G Y$ 6/1); weathers to grayish yellow green (5GY 7/2); slight tendency to form ridges......

132. Sandstone, volcanic, massive, very fine grained, silty, andesitic, greenishgray ( $5 G Y 6 / 1)$; weathers to light olive gray $(5 Y 6 / 1)$; poorly exposed .

131. Mudstone, massive, olive-gray (5Y $4 / 1$; weathers to light olive gray (5Y 6/1); poorly exposed ..........

130. Sandstone, volcanic, thin-bedded to massive, crossbedded, fine- to coarsegrained, andesitic, greenish-gray $(5 G Y 6 / 1)$; weathers to grayish yellow green $(5 G Y 7 / 2) \ldots$

129. Sandstone, volcanic, thin-bedded to massive, fine- to coarse-grained, interbedded with very fine grained massive sandstone, andesitic, greenish-gray (5GY 6/1); weathers to grayish yellow green $(5 G Y 7 / 2)$; forms slabby rubble on slope; poorly exposed............................

128. Sandstone, volcanic, thin-bedded to massive, crossbedded, fine- to coarsegrained, andesitic, slightly calcareous, greenish-gray ( $5 G Y \quad 6 / 1)$; weathers to grayish yellow green ( $5 G Y 7 ; 2)$; slight tendency to form ridges ..........................

127. Covered interval-probably very fine grained sandstone. ..............

126. Sandstone, volcanic, thin-bedded to massive, crossbedded, fine- to coarsegrained. (contains sporadic mudstone pebbles), andesitic, slightly calcareous, greenish-gray ( $5 G Y 6 / 1)$; 


\section{SECTION 20-Continued}

Reference section of the Fort Union Formation, measured in secs. 7, $16,17,21,28,32$, and $33, T .1$ S., R. 8 E.; secs. $2,3,11,12$, 13, and $2 S, T$. $2 S ., R .8 E$.; and secs. 7, 18, 19, and $20, T .2 S .$, R. 9 E., Park County, Mont.-Continued

Paleocene-Fort Union Formation-Continued Middle sandstone and mudstone member-Con. (5GY 7/2) slight tendency to form ridges weathers to grayish yellow green $(5 G Y 7 / 2)$; slight tendency to form ridges

125. Mudstone, massive, olive-gray ( $5 Y 4 / 1)$ weathers to light olive gray (5Y $6 / 1)$; very poorly exposed........

124. Sandstone, volcanic, thin-bedded to massive, crossbedded, fine- to coarsegrained (contains sporadic mudstone pebbles), andesitic, slightly calcareous, greenish-gray ( $5 G Y 6 / 1)$; weathers to grayish yellow green (5GY $7 / 2)$; ridge former........

123. Sandstone, volcanic, massive, very fine grained, silty andesitic, duskyyellow-green (5GY 5/2); weathers to light olive gray $(5 Y 6 / 1)$; contains macerated plant fragments; very poorly exposed.

122. Sandstone, volcanic, thin-bedded to massive, crossbedded, fine- to coarsegrained, andesitic, slightly calcareous, greenish-gray ( $5 G Y 6 / 1)$; contains some layers of small pebbles of mudstone, volcanic rock, limestone, and quartzite; weathers to grayish yellow green (5GY 7/2); ridge former..................

121. Sandstone, volcanic, massive, very fine grained, micaceous, andesitic, greenish-gray (5GY 6/1); weathers to light olive gray ( $5 Y 6 / 1)$; poorly exposed......................

120. Sandstone, volcanic, thin-bedded to massive, crossbedded, fine- to coarsegrained, andesitic, slightly calcareous, greenish-gray ( $5 G Y 6 / 1)$; weathers to grayish yellow green ( $5 G Y$ $7 / 2)$; ridge former. .............

119. Mudstone, massive, olive-gray (5Y $4 / 1$; weathers to light olive gray (5Y 6/1); very poorly exposed......

118. Sandstone, volcanic, thin-bedded to massive, fine- to coarse-grained, andestic, greenish-gray (5GY 6/1); weathers to grayish yellow green ( $5 G Y 7 / 2)$; contains some layers of mudstone and volcanic rock pebbles

117. Claystone, medium-bedded, olive-gray (5Y 4/1); weathers to light olive gray (5Y 6/1) _. .

116. Sandstone, volcanic, thin-bedded, finegrained, andesitic, slightly calcareous, greenish-gray ( $5 G Y 6 / 1)$; weathers to grayish yellow green $(5 G Y$ $7 / 2$ )
SEGTION 20-Continued

Reference section of the Fort Union Formation, measured in secs. 7 , 16, 17, 21, 28, 32, and 39, T. 1 S., R. 8 E.; secs. $2,3,11,12$ 13, and $23, T .2 S ., R .8 E$.; and secs. 7, 18, 19, and $20, T .2 S$. R. 9 E., Park County, Mont.-Continued

Paleocene-Fort Union Formation-Continued

Middle sandstone and mudstone member-Con

115. Sandstone, volcanic, massive, finegrained, andesitic, greenish-gray (5GY 6/1); weathers to yellowish gray $(5 Y 7 / 2)$

114. Sandstone, volcanic, thin-bedded, slightly crossbedded, medium- to coarse-grained, andesitic, locally calcareous, greenish-gray $(5 G Y \quad 6 / 1)$; weathers to grayish yellow green $(5 G Y 7 / 2)$

113. Mudstone, massive, olive-gray (5Y $4 / 1)$; weathers to light olive gray ( $5 Y$ $6 / 1)$

112. Sandstone, volcanic, thin-bedded to massive, crossbedded, medium- to coarse-grained, poorly sorted (contains sporadic mudstone pebbles), andesitic, slightly calcareous, greenish-gray ( $5 G Y 6 / 1)$; weathers to grayish yellow green ( $5 G Y 7 / 2)$; slight tendency to form ridges . . . . - .

111. Sandstone, volcanic, massive, finegrained, andesitic, greenish-gray ( $5 G Y$ 6/1); weathers to yellowish gray $(5 Y 7 / 2)$; massive spheroidal weathering

$F$

In.

120

100

120

183

228

110. Sandstone, volcanic, thin-bedded to massive, crossbedded, fine- to coarsegrained (generally coarse-grained), greenish-gray $(5 G Y \quad 6 / 1)$; weathers to grayish yellow green ( $5 G Y 7 / 2)$; ridge former

109. Sandstone, volcanic, massive, very fine grained, silty, andesitic, duskyyellow-green $(5 G Y 5 / 2)$; weathers to light olive gray ( $5 Y 5 / 2)$; contains plant fragments; poorly exposed...

108. Sandstone, volcanic, thin-bedded, finegrained, andesitic, greenish-gray (5GY 6/1); weathers to grayish yellow green $(5 G Y 7 / 2) \ldots \ldots \ldots$

107. Sandstone, volcanic, massive, very fine grained, silty, andesitic, duskyyellow-green ( $5 G Y 5 / 2)$; weathers to light olive gray $(5 Y 5 / 2)$

106. Sandstone, volcanic, thin-bedded to massive, crossbedded, fine- to coarsegrained, andesitic, slightly calcareous, greenish-gray ( $5 G Y 6 / 1$ ); weathers to light olive gray $(5 Y 5 / 2)$; ridge former. . . .

105. Sandstone, volcanic; massive, very fine grained, silty, andesitic, duskyyellow-green ( $5 G Y 5 / 2)$; weathers to light olive gray ( $5 Y 5 / 2)$; contains plant fragments...................... 


\section{SECTION 20-Continued}

Reference section of the Fort Union Formation, measured in secs. 7 , 16, 17, 21, 28, 32, and 33, T. 1 S., R. 8 E.; secs. 2, 3, 11, 12, 19, and 23, T. 2 S., R. 8 E.; and secs. 7, 18, 19, and 20, T. 2 S., R. 9 E., Park County, Mont.-Continued

Paleocene-Fort Union Formation-Continued

Middle sandstone and mudstone member-Con. Ft in. 104. Mudstone, massive, olive-gray (5Y $4 / 1)$; weathers to light olive gray (5Y 6/1); poorly exposed .........

103. Sandstone, volcanic, massive, very fine grained, silty, andesitic, dusky-yellow-green $(5 G Y 5 / 2)$; weathers to light olive gray $(5 Y 5 / 2)$

102. Sandstone, volcanic, thin- to mediumbedded, medium- to coarse-grained, andesitic, greenish-gray (5GY 6/1); weathers to grayish yellow green $(5 G Y 7 / 2)$

101. Sandstone, volcanic, massive, very fine grained, silty, andesitic, dusky-yellow-green $(5 G Y 5 / 2)$; weathers to light olive gray $(5 Y 5 / 2) \ldots \ldots$

100. Sandstone, volcanic, thin-bedded to massive, crossbedded, fine- to coarsegrained, andesitic, slightly calcareous, greenish-gray ( $5 G Y$ 6/1); weathers to grayish yellow green. ( $5 G Y$ $7 / 2)$; ridge former. . . . . . . . .

99. Claystone, thick-bedded, olive-gray (5Y 4/1); weathers to light olive gray (5Y 6/1) .....................

98. Sandstone, volcanic, thin-bedded to massive, crossbedded, medium- to coarse-grained, andesitic, greenishgray (5GY 6/1); weathers to grayish yellow green $(5 G Y 7 / 2) \ldots \ldots$

97. Mudstone, massive, olive-gray ( $5 Y$ $4 / 1)$; weathers to light olive gray (5Y 6/1); poorly exposed........

96. Sandstone, volcanic, thin-bedded to massive, crossbedded, fine- to coarsegrained (generally coarse-grained), andesitic, slightly calcareous, greenish-gray $(5 G Y 6 / 1)$; weathers to grayish yellow green (5GY 7/2); contains sporadic mudstone pebbles; thin bedded in upper part; slight tendency to form ridges............

95. Sandstone, volcanic, massive, very fine grained, silty, andesitic, duskyyellow-green $(5 G Y 5 / 2)$; weathers to light olive gray $(5 Y 5 / 2)$; contains macerated plant fragments.

94. Mudstone, massive, olive-gray ( $5 Y$ $4 / 1$ ); weathers to light olive gray $(5 Y 6 / 1)$

93. Sandstone, volcanic, thin-bedded to massive, crossbedded, fine- to coarsegrained (generally fine grained), andesitic, dusky-yellow-green ( $5 G Y$ $5 / 2)$; weathers to light olive gray $(5 Y 6 / 1)$ 20
SECTION 20-Continued

Reference section of the Fort Union Formation, measured in secs. 7 , 16, 17, 21, 28, 32, and 33, T. 1 S., R. 8 E.; secs. 2, 3, 11, 12, 13, and 29, T. 2 S., R. 8 E.; and secs. 7, 18, 19, and 20, T. \& S., R. 9 E., Park County, Mont.-Continued

Paleocene-Fort Union Formation-Continued Middle sandstone and mudstone member-Con.

92. Sandstone, volcanic, massive, very fine grained, silty, micaceous, andesitic dusky-yellow-green ( $5 G Y 5 / 2)$; weathers to light olive gray $(5 Y \quad 6 / 1)$; poorly exposed....................

91. Sandstone, volcanic, thin-bedded to massive, slightly crossbedded, fineto coarse-grained (generally finegrained with fair sorting), andesitic, slightly calcareous, greenish-gray ( $5 G Y 6 / 1)$; weathers to grayish yellow green ( $5 G Y 7 / 2)$; slight tendency to form ridges

90. Mudstone, massive, olive-gray (5Y $4 / 1)$; weathers to light olive gray $(5 Y 6 / 1)$; poorly exposed

Ft In. ndstone, volcanic, thin-bedded to massive, fine- to coarse-grained, very poorly sorted, andesitic, conglomeratic locally (containing pebbles of volcanic rock, quartzite, chert, and limestone), slightly calcareous, duskyyellow-green ( $5 G Y 5 / 2)$; weathers to grayish yellow green (5GY $7 / 2)$; slight tendency to form ridges . . . .....

88. Sandstone, volcanic, massive, finegrained, andesitic, dusky-yellowgreen ( $5 G Y 5 / 2)$; weathers to light olive gray ( $5 Y 6 / 1)$; poorly exposed.-.

87. Sandstone, volcanic, thin-bedded to massive, crossbedded, fine- to coarsegrained, andesitic, slightly calcareous, dusky-yellow-green $(5 G Y \cdot 5 / 2)$; weathers to grayish yellow green (5GY $7 / 2)$; contains sporadic mudstone pebbles; ridge former

86. Sandstone, volcanic, massive, fine- to very fine-grained, silty, andesitic, dusky-yellow-green $\quad(5 G Y \quad 5 / 2)$; weathers to light olive gray (5Y 6/1).

85. Sandstone, volcanic, thin-bedded to massive, crossbedded, fine- to coarsegrained, andesitic, slightly calcareous, dusky-yellow-green (5GY 5/2); weathers to light olive gray ( $5 Y 6 / 1)$; ridge former

84. Sandstone, volcanic, massive, fine- to very fine-grained, silty, andesitic, dusky-yellow-green $\quad(5 G Y \quad 5 / 2)$; weathers to light olive gray ( $5 Y$. 6/1) ; poorly exposed..............

83. Sandstone, volcanic, thin-bedded to massive, crossbedded, fine- to coarsegrained, very poorly sorted, andesitic; slightly calcareous, dusky-yellowgreen. ( $5 G Y 5 / 2)$; weathers to light olive gray ( $5 Y 6 / 1)$; contains sporadic pebbles of volcanic.rock; ridge former.
$48 \quad 11$

202 


\section{SECTION 20-Continued}

Reference section of the Fort Union Formation, measured in secs. 7 , $16,17,21,28,32$, and $33, T$. 1 S., R. 8 E.; secs. 2, 3, 11, 12, 19, and 2S, T. 2 S., R. 8 E.; and secs. 7, 18, 19, and $20, T .2$ S.। R. 9 E., Park County, Mont.-Continued

Paleocene-Fort Union Formation-Continued

Middle sandstone and mudstone member-Con. Ft $I n$.

82. Siltstone, massive, dusky-yellow-green ( $5 G Y 5 / 2)$; weathers to light olive gray $(5 Y 5 / 2)$

81. Sandstone, volcanic, thin-bedded to massive, crossbedded, fine- to coarsegrained, andesitic, locally calcareous, dusky-yellow-green $\quad(5 G Y \quad 5 / 2)$; weathers to light olive gray ( $5 Y 6 / 1)$; ridge former. . . . . . . .

80. Siltstone, massive, olive-gray ( $5 Y 4 / 1)$; weathers to light olive gray ( $5 Y$ 6/1) locally clayey; contains macerated plant fragments...............

79. Sandstone, volcanic, medium-bedded, fine-grained, andesitic, calcareous, medium-light-gray $(N 6)$; weathers to light olive gray ( $5 Y 5 / 2)$; contains macerated plant fragments........

78. Siltstone, massive, olive-gray ( $5 Y 4 / 1)$; weathers to light olive gray $(5 Y 6 / 1)$; contains macerated plant fragments; USGS Paleobotany loc. D1784 .....

77. Sandstone, volcanic, thin-bedded to massive, crossbedded, fine- to coarsegrained, poorly sorted, andesitic, slightly calcareous, dusky-yellowgreen ( $5 G Y 5 / 2)$; weathers to grayish yellow green $(5 G Y 7 / 2)$; locally contains channel-fill deposits of conglomeratic sandstone that bears pebbles and cobbles of volcanic rock, mudstone, quartzite, chert, and limestone; unit becomes more conglomeratic to the west; contains some crossbeds of granule-size grains; lower $62.5 \mathrm{ft}$ poorly exposed; upper part is prominent ridge former. ...........

76. Siltstone, sandy, clayey, micaceous, olive-gray ( $5 Y 4 / 1)$; weathers to light olive gray $(5 Y 6 / 1)$; poorly exposed.-

75. Claystone, massive, olive-gray (5Y 4/1); weathers to light olive gray $(5 Y 6 / 1)$; poorly exposed.......................

74. Sandstone, volcanic, thin-bedded to massive, crossbedded, fine- to coarsegrained, poorly sorted, andesitic, slightly calcareous, dusky-yellowgreen $(5 G Y 5 / 2)$; weathers to grayish yellow green ( $5 G Y 7 / 2)$; contains plant fragments. . . .

73. Mudstone, massive, olive-gray (5Y 4/1); weathers to light olive gray $(5 Y 6 / 1)$; poorly exposed

72. Sandstone, volcanic, thin-bedded to massive, crossbedded, fine- to coarse-

\section{SECTION 20-Continued}

Reference section of the Fort Union Formation, measured in secs. 7 $16,17,21,28,32$, and 39, T. 1 S., R. 8 E.; secs. 2, 3, 11, 12, 13, and $23, T .2 S ., R .8 E$.; and secs. $7,18,19$, and $20, T .2 S$. , R. 9 E., Park County, Mont.-Continued

Paleocene-Fort Union Formation-Continued

Middle sandstone and mudstone member-Con. grained, poorly sorted, andesitic, slightly calcareous, dusky-yellowgreen $(5 G Y 5 / 2)$; channel-fill sands of varying grain size and color cut underlying beds of this unit; the coarser grained beds are darker in color than the finer grained beds; the poor sorting is generally in the coarse-grained beds; contains mudstone pebbles in bottoms of channel deposits; coarser grained part weathers to light olive gray $(5 Y 5 / 2)$ and finer grained part, to pale olive $(10 Y 6 / 2)$ to yellowish gray (5Y 7/2); massive spheroidal weathering; cliff former. . . . . . . .

71. Mudstone, massive, olive-gray (5Y 4/1); weathers to light olive gray $(5 Y$ 6/1)

38

70. Sandstone, volcanic, thin-bedded, very fine grained, silty, andesitic, slightly calcareous, dusky-yellow-green ( $5 G Y$. $5 / 2$ ); weathers to light olive gray ( $5 Y$ $5 / 2)$

69. Sandstone, volcanic, thin-bedded to massive, crossbedded, fine- to coarsegrained, poorly sorted, andesitic, dusky-yellow-green ( $5 G Y 5 / 2)$; weathers to pale olive (10Y 6/2); contains plant fragments; ridge former........

68. Mudstone, massive, silty, slightly carbonaceous, olive-black (5Y 2/1); weathers to olive gray $(5 Y 4 / 1) \ldots \ldots$

67. Sandstone, volcanic, thin-bedded, very fine grained, silty, andesitic, slightly calcareous, dusky-yellow-green ( $5 G Y$ $5 / 2)$; weathers to light olive gray ( $5 Y$ $5 / 2)$

66. Siltstone, thick-bedded, olive-gray ( $5 Y$ 6/1); contains plant fragments; USGS Paleobotany loc. D1783.

65. Sandstone, volcanic, massive, crossbedded, medium- to coarse-grained, poorly sorted, andesitic, calcareous in upper part, dusky-yellow-green ( $5 G Y$ $5 / 2)$; weathers to light olive gray ( $5 Y$ $5 / 2)$; massive spheroidal weathering in lower part; contains sporadic pebbles of volcanic rock and mudstone; contains crossbedded lenses of granule-size grains; contains plant fragments; ridge former. . . . . . . . . . . . .

64. Siltstone, massive, dusky-yellow-green $4 / 1$ ); weathers to light olive gray (5Y (5GY 5/2); weathers to light olive gray (5Y 6/1) ; very poorly exposed.......
$108 \quad 0$

94

$17 \quad 3$

200

158

Ft In

20

23 


\section{SECTION 20-Continued}

Reference section of the Fort Union Formation, measured in secs. 7, $16,17,21,28,32$, and 33, T. 1 S., R. 8 E.; secs. 2, 3, 11, 12, 13, and 2S, T. 2 S., R. 8 E.; and secs. 7, 18, 19, and 20, T. 2 S., R. 9 E., Park County, Mont.-Continued

Paleocene-Fort Union Formation-Continued Middle sandstone and mudstone member-Con.

63. Sandstone, volcanic, medium-bedded to massive, fine- to coarse-grained, poorly sorted, andesitic, dusky-yellow-green $(5 G Y 5 / 2)$; weathers to grayish yellow green $(5 G Y 7 / 2)$; contains sporadic pebbles of volcanic rock; ridge former...............

62. Sandstone, volcanic, thin-bedded, very fine grained, silty, andesitic, duskyyellow-green ( $5 G Y 5 / 2)$; weathers to grayish yellow green $(5 G Y \quad 7 / 2)$; poorly exposed..........

61. Sandstone, volcanic, thin- to mediumbedded, fine- to coarse-grained, andesitic, slightly calcareous, duskyyellow-green ( $5 G Y 5 / 2)$; weathers to grayish yellow green $(5 G Y 7 / 2) \ldots \ldots$

60. Siltstone, thin-bedded, dusky-yellowgreen ( $5 G Y 5 / 2)$; weathers to light olive gray $(5 Y 6 / 1)$; poorly exposed..

59. Sandstone, thin- to medium-bedded, fine- to coarse-grained, dusky-yellowgreen ( $5 G Y 5 / 2)$; weathers to grayish yellow green ( $5 G Y 7 / 2)$; lower $12 \mathrm{ft}$ poorly exposed.

58. Siltstone, thin-bedded, dusky-yellowgreen ( $5 G Y 5 / 2)$; weathers to light olive gray ( $5 Y 6 / 1)$; contains macerated plant fragments.

57. Sandstone, volcanic, medium-bedded to massive, fine- to coarse-grained, poorly sorted, andesitic, dusky-yellow-green ( $5 G Y 5 / 2)$; weathers to grayish yellow green $(5 G Y 7 / 2)$; contains sporadic pebbles of volcanic rock; ridge former. . . . . . . . . . . .

56. Mudstone, massive, olive-gray (5Y 4/1); weathers to light olive gray ( $5 Y 6 / 1)$.

55. Sandstone, volcanic, thin-bedded to massive, crossbedded, coarse-grained to granule-size, very poorly sorted, andesitic, locally slightly calcareous, dusky-yellow-green ( $5 G Y 5 / 2)$; some crossbedded sands weather to grayish yellow green $(5 G Y 7 / 2)$ and some weather to yellowish gray $(5 Y 7 / 2)$; the yellowish-gray beds have massive spheroidal weathering and are very conspicuous compared to the other unit; contains sporadic pebbles of volcanic rock and mudstone in channel-fill deposits; contains $1.5 \mathrm{ft}$ siltstone bed in the middle.

54. Mudstone, massive, olive-gray (5Y 4/1); weathers to light olive gray $(5 Y 6 / 1)$.

Ft In.
360

$50 \quad 11$

$\begin{array}{ll}6 & 3\end{array}$

\section{$R$}

Reference section of the Fort Union Formation, measured in secs. 7, 16, 17, 21, 28, 32, and 33, T. 1 S., R. 8 E.; secs. 2, 3, 11, 12, 13, and $23, T .2 S ., R .8$ E.; and secs. $7,18,19$, and $20, T .2 S$., R. 9 E., Park County, Mont.-Continued

Paleocene-Fort Union Formation-Continued

Middle sandstone and mudstone member-Con.

53. Sandstone, volcanic, thin- to mediumbedded, crossbedded, medium- to coarse-grained, andesitic, slightly calcareous, dusky-yellow-green (5GY $5 / 2)$; weathers to grayish yellow green $(5 G Y 7 / 2)$; ridge former.......

52. Mudstone, massive, olive-gray (5Y 4/1); weathers to light olive gray (5Y 6/1).

51. Sandstone, volcanic, thin- to medium-bedded, crossbedded, mediumgrained, andesitic, slightly calcareous, dusky-yellow-green (5GY 5/2); weathers to grayish yellow green (5GY 7/2) .............

50. Claystone, massive, olive-gray (5Y 4/1); weathers to light olive gray ( $5 Y 6 / 1)$.

49. Sandstone, volcanic, massive, crossbedded, generally coarse grained, andesitic, dusky-yellow-green ( $5 G Y$ $5 / 2)$; weathers to grayish yellow green (5GY 7/2) ...................

48. Claystone, medium-bedded, olive-gray (5Y 4/1); weathers to light olive gray (5Y 6/1) .........................

47. Sandstone, volcanic, medium-bedded, medium- to coarse-grained, andesitic, dusky-yellow-green ( $5 G Y 5 / 2)$; weathers to grayish yellow green ( $5 G Y 7 / 2$ ) -

46. Claystone, medium-bedded, olive-gray (5Y 4/1); weathers to light olive gray $(5 Y 6 / 1)$

45. Sandstone, volcanic, thick-bedded, crossbedded, generally coarse grained, poorly sorted, andesitic, dusky-yellow-green $(5 G Y \quad 5 / 2)$; weathers to grayish yellow green (5GY 7/2) ...

44. Claystone, medium-bedded, olive-gray (5Y 4/1); weathers to light olive gray $(5 Y 6 / 1)$

43. Sandstone, volcanic, thin-bedded, finegrained, andesitic, dusky-yellow-green ( $5 G Y 5 / 2)$; weathers to grayish yellow green $(5 G Y 7 / 2)$

42. Mudstone, massive, olive-gray (5Y 4/1); weathers to light olive gray ( $5 Y 6 / 1)$; poorly exposed........................

41. Sandstone, volcanic, thin-bedded to massive, crossbedded, fine- to coarsegrained, poorly sorted, andesitic, dusky-yellow-green $\quad(5 G Y \quad 5 / 2)$; weathers to grayish yellow green ( $5 G Y$ $7 / 2)$; contains fossil leaf prints; ridge former . . . . . . . . . . .

40. Mudstone, massive, brownish-black (5YR 2/1); weathers to light olive gray $(5 \square 6 / 1)$ 


\section{SECTION 20-Continued}

Reference section of the Fort Union Formation, measured in secs. 7 , 16, 17, 21, 28, 32, and 38, T. 1 S., R. 8 E.; secs. $2,3,11,12$, 19, and 2S, T. 2.S., R. 8 E.; and secs. 7, 18, 19, and 20, T. 2 S., R. 9 E., Park County, Mont.-Continued

Paleocene-Fort Union Formation-Continued

$M$ iddle sandsone and mudstone member-Con.

39. Sandstone, volcanic, thin-bedded to massive, crossbedded, andesitic, very poorly sorted, dusky-yellow-green ( $5 G Y 5 / 2)$; weathers to grayish yellow green $(5 G Y 7 / 2)$ and yellowish gray (5Y $7 / 2)$; contains coarse-grained channel-fill deposits; contains some calcareous lenses; rịdge former......

38. Siltstone, thin-bedded, sandy, duskyyellow-green $(5 G Y 5 / 2)$; weathers to light olive gray $(5 Y 6 / 1) \ldots \ldots$

37. Mudstone, massive, olive-gray ( $5 Y 4 / 1$ ); weathers to pale olive $(10 Y 6 / 2) \ldots$

Total thickness of middle sandstone and mudstone member.... $3,866 \quad 0$

Upper Cretaceous-Fort Union Formation:

Lower conglomeratic sandstone member:

36. Sandstone, volcanic, thin- to mediumbedded, coarse-grained, andesitic, dusky-yellow-green $\quad(5 G Y \quad 5 / 2)$ weathers to grayish yellow green (5GY 7/2); poorly indurated and poorly exposed..................

35. Sandstone, volcanic, thin- to mediumbedded, generally coarse grained, andestic, slightly calcareous, duskyyellow-green ( $5 G Y 5 / 2)$; weathers to grayish yellow green $(5 G Y 7 / 2) \ldots$

34. Siltstone, massive, sandy, dusky-yellowgreen ( $5 G Y 5 / 2)$; weathers to light olive gray ( $5 Y 6 / 1)$; poorly exposed..

33. Sandstone, volcanic, thin-bedded, generally fine grained (contains a few scattered layers of medium- to coarsegrained sand), andesitic, calcareous, dusky-yellow-green $\quad(5 G Y \quad 5 / 2)$; weathers to grayish yellow green (5GY 7/2)

32. Sandstone, volcanic, medium- to thickbedded, coarse-grained, very poorly sorted (contains sporadic pebbles of volcanic rock and mudstone), slightly calcareous, dusky-yellow-green ( $5 G Y$ $5 / 2)$; weathers to grayish yellow green (5GY 7/2); contains macerated plant fragments; ridge former

31. Siltstone, thin-bedded, sandy, duskyyellow-green ( $5 G Y 5 / 2)$; weathers to grayish yellow green $(5 G Y 7 / 2) \ldots \ldots$

30. Sandstone, volcanic, thin-bedded to massive, crossbedded, fine- to coarse-

\section{SECTION 20-Continued}

Reference section of the Fort Union Formation, measured in secs. 7 , $16,17,21,28,32$, and 33, T. 1 S., R. 8 E.; secs. 2, 3, 11, 12, 13, and $23, T$. $2 S ., R .8 E$.; and secs. $7,18,19$, and $20, T .2 S$. , R. 9 E., Park County, Mont.-Continued

Upper Cretaceous-Fort Union Formation-Con.

Lower conglomeratic sandstone member-Con. grained, very poorly sorted, andesitic, slightly calcareous, dusky-yellowgreen $(5 G Y 5 / 2)$; weathers to yellowish gray (5Y 7/2); conglomeratic in channel-fill deposits which contain pebbles of volcanic rock and chert; the channel-fill beds are in the lower one-third of unit; above the channelfill beds the unit gradually becomes fine grained and thin bedded, although still crossbedded; ridge former with unit 28

29. Siltstone, thin-bedded, sandy, duskyyellow-green ( $5 G Y 5 / 2)$; weathers to grayish yellow green ( $5 G Y 7 / 2)$; contains macerated plant fragments; poorly exposed.

Ft $\quad$ m ndstone, volcanic, thin-bedded to massive, crossbedded, fine- to coarsegrained, very poorly sorted, andesitic, slightly calcareous, dusky-yellowgreen $(5 G Y 5 / 2)$; weathers to yellowish gray ( $5 Y 7 / 2)$; conglomeratic in channel-fill deposits which contain pebbles of volcanic rock and chert.--

27. Mudstone, massive, olive-gray ( $5 Y 4 / 1)$; weathers to light olive gray $(5 Y 6 / 1)$; poorly exposed..........

26. Sandstone, volcanic, thin-bedded, fineto very fine grained, silty, andesitic, dusky-yellow-green $\quad(5 G Y \quad 5 / 2)$; weathers to pale olive (10Y 6/2); poorly exposed.................

25. Sandstone, volcanic, thin- to mediumbedded, fine-grained, andesitic, dusky-yellow-green $\quad(5 G Y \quad 5 / 2)$; weathers to grayish yellow green

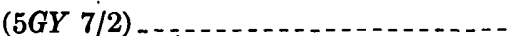

24. Sandstone, volcanic, thin-bedded, fineto very fine grained, silty, andesitic, dusky-yellow-green $\quad(5 G Y \quad 5 / 2)$; weathers to pale olive (10Y 6/2); contains macerated plant fragments; USGS Paleobotany locs. D1782 and D4105

23. Sandstone, volcanic, massive, crossbedded, coarse-grained (contains sporadic pebbles of volcanic rock), very poorly sorted, andesitic, duskyyellow-green ( $5 G Y 5 / 2)$; weathers to grayish yellow green $(5 G Y 7 / 2)$...--

22. Siltstone, massive, sandy, dusky-yellowgreen ( $5 G Y 5 / 2)$; weathers to dusky yellow (5Y 6/4); poorly exposed....
18

32

$17 \quad 1$




\section{SECTION 20-Continued}

Reference section of the Fort Union Formation, measured in secs. 7, 16, 17, 21, 28, 32, and 33, T. 1 S., R. 8 E.; secs. 2, 3, 11, 12, 13, and 2S, T. $2 S$., R. 8 E.; and secs. 7; 18, 19, and 20, T. $2 S$. , R. 9 E., Park County, Mont.-Continued

Upper Cretaceous-Fort Union Formation-Con.

Lower conglomeratic sandstone member-Con.

21. Sandstone, volcanic, thin-bedded to massive, crossbedded, very poorly sorted, conglomeratic (pebbles dominantly composed of volcanic rock and mudstone but include some white pumice fragments), duskyyellow-green ( $5 G Y 5 / 2)$; weathers to grayish yellow green (5GY 7/2); prominent ridge former . . . . . . . -

20. Sandstone, volcanic, massive, fine- to coarse-grained, crossbedded, andesitic, dusky-yellow-green ( $5 G Y 5 / 2)$; weathers to yellowish gray (5Y 7/2); consists of channel-fill deposits that contain sporadic pebbles of volcanic rock

19. Sandstone, volcanic, thin-bedded to massive, fine- to coarse-grained, conglomeratic (pebbles dominantly composed of volcanic rock and mudstone), dusky-yellow-green ( $5 G Y 5 / 2)$; weathers to grayish yellow green ( $5 G Y 7 / 2)$; slight ridge former

18. Sandstone, volcanic, massive, fine- to medium-grained, andesitic, duskyyellow-green ( $5 G Y 5 / 2)$; weathers to grayish yellow green $(5 G Y 7 / 2)$

17. Sandstone, volcanic, thin-bedded to massive, crossbedded, fine- to coarsegrained, andesitic, dusky-yellowgreen ( $5 G Y 5 / 2)$; weathers to grayish yellow green $(5 G Y 7 / 2)$; contains fragments of petrified wood.......-

16. Mudstone, massive, olive-gray (5Y 4/1); weathers to light olive gray (5Y 6/1) ..............................

15. Sandstone, volcanic, thin-bedded to massive, crossbedded, fine- to coarsegrained, andesitic, dusky-yellow-green (5GY 5/2); weathers to grayish yellow green $(5 G Y 7 / 2)$

14. Mudstone, massive, olive-gray ( $5 Y 4 / 1)$; weathers to light olive gray ( $5 Y 6 / 1)$.

13. Sandstone, volcanic, thin-bedded to massive, crossbedded, fine- to coarsegrained, andesitic, dusky-yellow-green $(5 G Y 5 / 2)$; weathers to grayish yellow green (5GY 7/2); slight tendency to form ridges. ...

12. Covered interval-probably duskyyellow-green siltstone...........

11. Sandstone, volcanic, thin-bedded to massive, crossbedded, fine- to coarsegrained, andesitic, contains a few thin channel-fill deposits that bear pebbles of volcanic rock and mud-

\section{SECTION 20-Continued}

Reference section of the Fort Union Formation, measured in secs. 7 , $16,17,21,28,32$, and $33, T .1$ S., R. 8 E.; secs. $2,3,11,12$, 13, and 23, T. 2 S., R. 8 E.; and secs. 7, 18, 19, and 20, T. 2 S., R. 9 E., Park County, Mont.-Continued

Upper Cretaceous-Fort Union Formation-Con.

Lower conglomeratic sandstone member-Con. stone, dusky-yellow-green ( $5 G Y 7 / 2)$; cliff former

Ft In.
Ft In.

13

6
10. Sandstone, volcanic, thin-bedded to massive, crossbedded, fine-grained to conglomeratic, dusky-yellow-green (5GY 5/2); weathers to grayish yellow green ( $5 G Y 7 / 2)$; contains channel-fill deposits that bear pebbles dominantly composed of volcanic rock and mudstone . . . . . . .

9. Sandstone, volcanic, thin-bedded to massive, crossbedded, fine- to coarsegrained, andesitic, thin-bedded in upper $40 \mathrm{ft}$ of unit, dusky-yellowgreen ( $5 G Y 5 / 2)$; weathers to grayish yellow green ( $5 G Y \quad 7 / 2)$; contains macerated plant fragments and small calcareous concretions; ridge former - -

8. Covered interval-probably duskyyellow-green siltstone..............

7. Sandstone, volcanic, thin-bedded to massive, crossbedded, coarse-grained to conglomeratic, very poorly sorted, andesitic, dusky-yellow-green ( $5 G Y$ $5 / 2)$; weathers to light olive gray (5Y 5/2) ; contains channel-fill deposits.

6. Siltstone, massive, dusky-yellow-green $(5 G Y 5 / 2)$; weathers to yellowish gray $(5 Y 7 / 2)$

5. Sandstone, volcanic, thin-bedded to massive, crossbedded, fine- to coarsegrained, poorly sorted, andesitic, dusky-yellow-green ( $5 G Y 5 / 2)$; weathers to light olive gray ( $5 Y 5 / 2)$; contains wood and plant fragments......-

4. Siltstone, massive, dusky-yellow-green $(5 G Y 5 / 2)$; weathers to yellowish gray (5Y 7/2); poorly exposed...........

3. Sandstone, volcanic, thin-bedded to massive, crossbedded, coarse-grained to conglomeratic, very poorly sorted, dusky-yellow-green ( $5 G Y 5 / 2)$; weathers to light olive gray ( $5 Y 5 / 2)$; unit is a channel-fill deposit; pebbles include andesites, intrusive porphyries, welded tuffs, Precambrian metamorphic rocks, and lesser amounts of Paleozoic and Mesozoic sedimentary rocks; many individual beds would be termed conglomerates; ridge former . . . . . . . -

2. Mudstone, massive, olive-gray, (5Y 4/1); weathers to light olive gray $(5 Y 6 / 1)$ - -

1. Sandstone, volcanic, thin-bedded to massive, crossbedded, coarse-grained to conglomeratic, very poorly sorted, andesitic, dusky-yellow-green ( $5 G Y 5 / 2)$; weathers to light olive gray $(5 Y 5 / 2)$ 


\section{SECTION 20-Continued}

Reference section of the Fort Union Formation, measured in secs. 7 , 16, 17, 21, 28, 32, and 33, T. 1 S., R. 8 E.; secs. 2, 3, 11, 12, 13 , and $2 S, T .2 S ., R .8 E$.; and secs. $7,18,19$, and $20, T .2 S$. ., R. 9 E., Park County, Mont.-Continued

Upper Cretaceous-Fort Union Formation-Con. Lower conglomeratic sandstone member-Con. this is a channel-fill deposit that cuts into underlying units; cobbles and pebbles include andesites, intrusive porphyries, welded tuffs, Precambrian metamorphic rocks, and lesser amounts of Paleozoic and Mesozoic sedimentary rocks as much as 4 in. in diameter; ridge former.........................

Total thickness of lower conglomeratic sandstone member

Ft In.

Total measured Fort Union Formation..................... 6,647

Upper Cretaceous-Livingston Group-Hoppers Formation.

\section{REFERENCES CITED}

Armstrong, F. C., and Oriel, S. S., 1965, Tectonic development of Idaho-Wyoming thrust belt: Am. Assoc. Petroleum Geologists Bull., v. 49, no. 11, p. 1847-1866.

Berry, G. W., 1943, Stratigraphy and structure at Three Forks, Montana: Geol. Soc. America Bull., v. 54, no. 1, p. 1-30.

Billingsley, Paul, 1915, The Boulder batholith of Montana: Am. Inst. Mining Engineers Trans., v. 51, p. 31-47.

Bowen, C. F., 1918, Anticlines in a part of the Musselshell Valley, Musselshell, Meagher, and Sweetgrass Counties, Mont.: U.S. Geol. Survey Bull. 691-F, p. 185-209.

1920, Gradations from continental to marine conditions of deposition in central Montana during the Eagle and Judith River epochs: U.S. Geol. Survey Prof. Paper 125-B, p. 11-21.

Bradley, W. H., 1930, The occurrence and origin of analcite and meerschaum beds in the Green River Formation of Utah, Colorado, and Wyoming: U.S. Geol. Survey Prof. Paper 158-A, 7 p.

Brown, C. W., 1957, Stratigraphic and structural geology of north central-northeast Yellowstone National Park, Wyoming and Montana: Princeton, N.J., Princeton Univ., $\mathrm{Ph}$. D. thesis (available on microfilm from University Microfilms, Inc., Ann Arbor, Mich.).

1961, Cenozoic stratigraphy and structural geology, northeast Yellowstone National Park, Wyoming and Montana: Geol. Soc. America Bull., v. 72, no. 8, p. 1173-1194.

Brown, R. W., 1939, Fossil plants from the Colgate Member of the Fox Hills Sandstone and adjacent strata : U.S. Geol. Survey Prof. Paper 189-I, p. 239-271.

1946, Fossil plants and Jurassic-Cretaceous boundary in Montana and Alberta: Am. Assoc. Petroleum Geologists Bull., v. 30, no. 2, p. 238-248.

1949, Paleocene deposits of the Rocky Mountains and Plains: U.S. Geol. Survey Mineral Resource Prelim. Map, scale $1: 1,000,000$.

1962, Paleocene flora of the Rocky Mountains and Great Plains: U.S. Geol. Surver Prof. Paper 375, 119 D.
Calvert, W. R., 1908, The Lewistown coal fleld, Montana, in Part 2, Coal and lignite: U.S. Geol. Survey Bull. 341, p. 108-122.

1912a, The Livingston and Trail Creek coal fields, Park, Gallatin, and Sweetgrass Counties, Montana, in Part 2, Mineral fuels: U.S. Geol. Survey Bull. 471, p. 384-405.

1912b, The Electric coal field, Park County, Montana, in Part 2, Mineral fuels: U.S. Geol. Survey Bull. 471, p. 406422.

- 1917, Geology of the Upper Stillwater Basin, Stillwater and Carbon Counties, Montana, with special reference to coal and oil: U.S. Geol. Survey Bull. 641-G, p. 199-214.

Chadwick, R. A., 1969, The Northern Gallatin Range, Montananorthwestern part of the Absaroka-Gallatin volcanic fleld: Wyoming Univ. Contrib. Geology, v. 8, no. 2, pt. 2, p. 150166 [1970].

Chamberlin, R. T., 1919, A peculiar belt of oblique faulting Jour. Geology, v. 27, p. 602-613.

1940, Diastrophic behavior around the Bighorn Basin: Jour. Geology, v. 48, p. 673-716.

Cobban, W. A., 1945, Marine Jurassic formations of Sweetgrass arch, Montana: Am. Assoc. Petroleum Geologists Bull., v. 29 , no. 9, p. 1262-1303.

- 1951, Colorado shale of central and northwestern Montana and equivalent rocks of Black Hills: Am. Assoc. Petroleum Geologists Bull., v. 35, no. 10, p. 2170-2198. 1955, Cretaceous rocks of northwestern Montana in Billings Geol. Soc. Guidebook 6th Ann. Field Conf., Sweetgrass arch-Disturbed belt, Montana, September 1955: p. 107-119.

1958, Late Cretaceous fossil zones of the Powder River Basin, Wyoming and Montana in Wyoming Geol. Assoc. Guidebook 13th Ann. Field Oonf., Powder River Basin, 1958: p. 114-119.

1962a, New baculites from the Bearpaw Shale and equivalent rocks of the Western Interior: Jour. Paleontology, v. 36, no. 1, p. 126-135.

- 1962b, Baculites from the lower part of the Pierre Shale and equivalent rocks in the Western Interior: Jour. Paleontology, v. 36, no. 4, p. 704-718.

Cobban, W. A., and Reeside, J. B., Jr., 1951, Lower Cretaceous ammonites in Colorado, Wyoming, and Montana: Am. Assoc. Petroleum Geologists Bull., v. 35, no. 8, p. 1892-1893. 1952a, Frontier Formation, Wyoming and adjacent areas : Am. Assoc. Petroleum Geologists Bull., v. 36, no. 10, p. 19131961.

- 1952b, Correlation of the Cretaceous formations of the Western Interior of the United States: Geol. Soc. America Bull., v. 63, no. 10, p. 1011-1044.

Cobban, W. A., Erdmann, C. E., Lemke, R. W., and Maughan, E. K., 1959, Revision of Colorado Group on Sweetgrass arch, Montana: Am. Assoc. Petroleum Geologists Bull., v. 43, no. 12 , p. $2786-2796$

Collier, A. J., 1922, The Osage oil field, Weston County, Wyoming : U.S. Geol. Survey Bull. 736-D, p. 71-110.

Darton, N. H., 1901, Preliminary description of the geology and water resources of the southern half of the Black Hills and adjoining regions in South Dakota and Wyoming: U.S. Geol. Survey 21st Ann. Rept., pt. 4, p. 489-599.

1904, Comparison of the stratigraphy of the Black Hills, Bighorn Mountains, and Rocky Mountain Front Range: Geol. Soc. America Bull., v. 15, p. 379-448.

1906, Geology of the Bighorn Mountains: U.S. Geol. Survèy Prof. Paper 51, 129 p. 
Darton, N. H., and O'Harra, C. C., 1909, Description of Belle Fourche quadrangle, South Dakota: U.S. Geol. Survey Geol. Atlas, Folio 164, 9 p.

Davis, W. M., 1886, Relation of the coal of Montana to the older rocks in Report on the mining industries of the United States, 1880: U.S. Census, 10th, v. 15, p. 697-712.

Dobbin, C. E., and Erdmann, C. E., 1955, Structure contour map of the Montana plains: U.S. Geol. Survey Oll and Gas Inv. Map OM-178A, scale $1: 500,000$.

Dobbin, C. E., and Horn, G. H., 1949, Geology of the Mush Creek and Osage oil fields and vicinity, Weston County, Wyoming: U.S. Geol. Survey Oil and Gas Inv. Prelim. Map. 103, scale 1 inch to 2 miles $(1: 126,720)$.

Eicher, D. L., 1960, Stratigraphy and micropaleontology of the Thermopolis Shale [Wyoming]: Yale Univ., Peabody Mus. Nat. History Bull. 15, 126 p.

Eldridge, G. W., 1886, Montana coal fields in Report on the mining industries of the United States, 1880: U.S. Census, 10th, v. 15, p. 739-757, 781-789.

Fisher, C. A., 1908, Southern extension of the Kootenai and Montana coal-bearing formations in northern Montana: Econ. Geology, v. 3, no. 1, p. 77-99.

1909, Geology of the Great Falls coal field, Montana : U.S. Geol. Survey Bull. 356, 85 p.

Foose, R. M., Wise, D. U., and Garbarini, G. S., 1961, Structural geology of the Beartooth Mountains, Montana and Wyoming: Geol. Soc. America Bull., v. 72, no. 8, p. 1143-1172.

Fox, S. K., Jr., 1939, The stratigraphy and micropaleontology of the Cody Shale in southern Montana and northern Wyoming: Princeton, N.J., Princeton Univ., Ph. D. thesis (available on microfilm from University Microfilms, Inc., Ann Arbor, Mich.).

Fraser, G. D., Waldrop, H. A., and Hyden, H. J., 1969, Geology of the Gardiner area, Park County, Montana: U.S. Geol. Survey Bull. 1277, 118 p.

Garbarini, G. S., 1957, Geology of the McLeod area, Beartooth Range, Montana: Princeton, N.J., Princeton Univ., Ph. D. thesis (available on microfilm from University Microfilms, Inc., Ann Arbor, Mich.).

Gardner, L. S., Hendricks, T. A., Hadley, H. D., and Rogers, C. P., 1945, Columnar sections of Mesozoic and Paleozoic rocks in the mountains of south-central Montana: U.S. Geol. Survey Oil and Gas Inv. Prelim. Chart. 18.

Gill, J. R., and Cobban, W. A., 1961, Stratigraphy of lower and middle parts of the Pierre Shale, northern Great Plains: U.S. Geol. Survey Prof. Paper 424-D, p. D185-D191.

1962, Red Bird Silty Member of the Pierre Shale, a new stratigraphic unit: U.S. Geol. Survey Prof. Paper 450-B, p. B21-B24.

1966, The Red Bird section of the Upper Cretaceous Pierre Shale in Wyoming: U.S. Geol. Survey Prof. Paper 393-A, 73 p.

Goddard, E. N., chm., and others, 1948, Rock-color chart: Washington, D.C., Natl. Research Council (repub. by Geol. Soc. America, 1951), $6 \mathrm{p}$.

Hackett, O. M., Visher, F. N., McMurtrey, R. G., and Steinhilber, W. L., 1960, Geology and ground-water resources of the Gallatin Valley, Gallatin County, Mont.: U.S. Geol. Survey Water-Supply Paper 1482, 282 p.

Hague, Arnold, Iddings, J. P., Weed, W. H., Walcott, C. D., Girty, G. H., Stanton, T. W., and Knowlton, F. H., 1899, Geology of the Yellowstone National Park; Part 2, Descriptive geology, petrography, and paleontology: U.S. Geol. Survey Mon. 32, 893 p.
Hancock, E. T., 1918, Geology and oil and gas prospects of the Lake Basin field, Montana : U.S. Geol. Survey Bull. 691-D, p. 101-147.

- 1920, The Mule Creek oil field, Wyoming: U.S. Geol. Survey Bull. 716-C, p. 35-53.

Häntzschel, Walter, 1962, Trace fossils and Problematica in Moore, R. C., ed., Treatise on invertebrate paleontologyPart W, Miscellanea: New York and Lawrence, Kans., Geol. Soc. America and Univ. Kansas Press, p. W177-W259.

Hares, C. J., 1916, Anticlines of central Wyoming: U.S. Geol. Survey Bull. 641-I, p. 233-279.

1917, Gastroliths in the Cloverly Formation: Wash. Acad. Sci. Jour., v. 7, p. 429.

Hatcher, J. B., and Stanton, T. W., 1903, The stratigraphic position of the Judith River beds and their correlation with the Belly River beds: Science, new ser., v. 18, no. 450, p. 211-212.

Hewett, D. F., 1914, The Shoshone River section, Wyoming: U.S. Geol. Survey Bull. 541, p. 89-113.

Hewitt, D. F., and Lupton, C. T., 1917, Anticlines in the southern part of the Bighorn basin, Wyoming: U.S. Geol. Survey Bull. 656, $192 \mathrm{p}$.

Hintze, F. F., Jr., 1915, The Basin and Greybull oil and gas fields: Wyoming Geol. Survey Bull. 10, 62 p.

Horberg, Leland, 1940, Geomorphic problems and glacial geology of the Yellowstone Valley, Park County, Montana: Jour. Geology, v. 48, p. 275-303.

Horn, G. H., 1959, Geologic and structure map of the West Salt Creek oil field, Natrona County, Wyoming: U.S. Geol. Survery open-file rept., 1 map.

Hose, R. K., 1955, Geology of the Crazy Woman Creek area, Johnson County, Wyoming: U.S. Geol. Survey Bull. 1027-B, p. 33-118.

Houston, R. S., and Murphy, J. F., 1962, Titaniferous black sandstone deposits of Wyoming: Wyoming Geol. Survey Bull. 49, 120 p.

Iddings, J. P., and Weed, W. H., 1894, Description of the Livingston sheet [Montana]: U.S. Geol. Survey Geol. Atlas, Folio 1,5 p.

James, H. L., 1946, Chromite deposits near Red Lodge, Carbon County, Mont.: U.S. Geol. Survey Bull. 945-F, p. 151-189.

Jones, W. R., Peoples, J. W., and Howland, A. L., 1960, Igneous and tectonic structures of the Stillwater Complex, Montana: U.S. Geol. Survey Bull. 1071-H, p. 281-340.

Keefer, W. R., 1957, Geology of the DuNoir area, Fremont County, Wyoming: U.S. Geol. Survey Prof. Paper 294-E, p. 155-221.

1970, Structural geology of the Wind River Basin, Wyoming: U.S. Geol. Survey Prof. Paper 495-D, 37 p.

Keefer, W. R., and Rich, E. I., 1957, Stratigraphy of the Cody Shale and younger Cretaceous and Paleocene rocks in the western and southern parts of the Wind River Basin, Wyoming, in Wyoming Geol. Assoc. Guidebook 12th Ann. Field Conf., southwest Wind River Basin, Lander, Wyoming, September $1957:$ p. 71-78.

Keefer, W. R., and Troyer, M. L., 1964, Geology of the Shotgun Butte area, Fremont County, Wyoming: U.S. Geol. Survey Bull. 1157, $123 \mathrm{p}$.

Klepper, M. R., Weeks, R. A., and Ruppel, E. T., 1957, Geology of the southern Elkhorn Mountains, Jefferson and Broadwater Counties, Montana: U.S. Geol. Survey Prof. Paper $292,82 \mathrm{p}$. 
Knappen, R. S., and Moulton, G. F., 1931, Geology and mineral resources of parts of Carbon, Bighorn, Yellowstone, and Stillwater Counties, Montana: U.S. Geol. Survey Bull 822-A, p. 1-70.

Knechtel, M. M., and Patterson, S. H., 1956, Bentonite deposits in marine Cretaceous formations of the Hardin district, Montana and Wyoming: U.S. Geol. Survey Bull. 1023, $116 \mathrm{p}$. 1962, Bentonite deposits of the northern Black Hills district, Wyoming, Montana, and South Dakota: U.S. Geol. Survey Bull. 1082-M, p. 893-1027.

Knight, W. C., 1902, The petroleum fields of Wyoming: Eng. Mining Jour., v. 73, p. 720-723.

Knowlton, F. H., 1892, The fossil flora of the Bozeman coal field: Biol. Soc. Washington Proc., v. 7, p. 153-154.

Lammers, E. C. H., 1939, The origin and correlation of the Cloverly conglomerate: Jour. Geology, v. 47, no. 2, p. 113-132.

Lee, W. T., 1927, Correlation of geologic formations between east-central Colorado, central Wyoming, and southern Montana: U.S. Geol. Survey Prof. Paper 149, 80 p.

Lesquereux, Leo, 1873, Lignitic formation and fossil flora in Hayden, F. V., United States geological survey of the Territories, 6th annual report, 1872 : Washington, D.C., p. 317427.

Lindgren, Waldemar, 1886, Eruptive rocks (of Montana) in Report on the mining industries of the United States: U.S. Census, 10th, v. 15, p. 719-737.

Love, J. D., 1948, Mesozoic stratigraphy of the Wind River Basin, central Wyoming, in Wyoming Geol. Assoc. Guidebook 3d Ann. Field Conf., Wind River Basin, Casper, Wyoming, 1948: p. 96-111.

1956, Cretaceous and Tertiary stratigraphy of the Jackson Hole area, northwestern Wyoming, in Wyoming Geol. Assoc. Guidebook 11th Ann. Field Conf., Jackson Hole, Wyoming, 1956 : p. 76-94.

Lupton, C. T., 1916, Oil and gas near Basin, Bighorn County, Wyoming, in Part 2, Mineral Fuels: U.S. Geol. Survey Bull. 621-L, p. 157-190.

Lyons, J. B., 1944, Igneous rocks of the northern Big Belt Range, Montana: Geol. Soc. America Bull., v. 55, p. 445472.

McMannis, W. J., 1955, Geology of the Bridger Range, Montana: Geol. Soc. America Bull., v. 66, no. 11, p. 1385-1430.

1963, LaHood Formation-a coarse facies of the Belt Series in southwestern Montana: Geol. Soc. America Bull., v. 74, p. 407-436.

- 1965, Résumé of depositional and structural history of western Montana: Am. Assoc. Petroleum Geologists Bull., v. 49 , no. 11 , p. 1801-1823.

McMannis, W. J., and Chadwick, R. A., 1964, Geology of the Garnet Mountain quadrangle, Gallatin County, Montana : Montana Bur. Mines and Geology Bull. 43, 47 p.

Mapel, W. J., 1959, Geology and coal resources of the BuffaloLake De Smet area, Johnson and Sheridan Counties, Wyoming: U.S. Geol. Survey Bull. 1078, 148 p.

Mapel, W. J., Robinson, C. S., and Theobald, P. K., 1959, Geologic and structure contour map of the northern and western flanks of the Black Hills, Wyoming, Montana, and South Dakota : U.S. Geol. Survey Oil and Gas Inv. Map OM-191, scale $1: 96,000$.

Moberly, Ralph, Jr., 1960, Morrison, Cloverly, and Sykes Mountain formations, northern Bighorn Basin, Wyoming and Montana : Geol. Soc. America Bull., v. 71, no. 8, p. 1137-1176.
Osterwald, F. W., 1961, Critical review of some tectonic problems in Cordilleran foreland: Am. Assoc. Petroleum Geologists Bull., v. 45, no. 2, p. 219-237.

Parsons, W. H., 1942, Origin and structure of the Livingston igneous rocks, Montana: Geol. Soc: America Bull., v. 53, no. 8 , p. 1175-1186.

Peale, A. C., 1896, Description of the Three Forks sheet [Montana] : U.S. Geol. Survey Geol. Atlas, Folio 24, 7 p., 4 maps.

Peck, R. E., 1941, Lower Cretaceous Rocky Mountain nonmarine microfossils: Jour. Paleontology, v. 15, no. 3, p. 285-304.

Pierce, W. G., 1957, Heart Mountain and South Fork detachment thrusts of Wyoming: Am. Assoc. Petroleum Geologists Bull., v. 41, no. 4, p. 591-626.

- 1963, Cathedral Cliffs Formation, the early acid breccia unit of northwestern Wyoming: Geol. Soc. America Bull., v. 74, no. 1, p. 9-22.

Post, E. V., and Bell, Henry, 3d, 1961, Chilson Member of the Lakota Formation in the Black Hills, South Dakota and Wyoming: U.S. Geol. Survey Prof. Paper 424-D, p. D173D178.

Prucha, J. J., Grahlam, J. A., and Nickelsen, R. P., 1965, Basement-controlled deformation in Wyoming province of Rocky Mountains foreland: Am. Assoc. Petroleum Geologists Bull., v. 49, no. 7, p. 966-992.

Pumpelly, Raphael, 1886, Bituminous coals and lignites of the Northwest in Report on the mining industries of the United 'States, 1880 : U.S. Census, 10th, v. 15, p. 691-695.

Reeside, J. B., Jr., 1927, The cephalopods of the Eagle sandstone and related formations in the Western Interior of the United States: U.S. Geol. Survey Prof. Paper 151, 87 p.

- 1944, Map showing thickness and general character of the Cretaceous deposits in the Western Interior of the United IStates: U.S. Geol. Survey Oil and Gas Inv. Prelim. Map 10, scale 1 inch to 3 miles $(1: 633,600)$.

1957, Paleoecology of the Cretaceous seas of the Western. Interior of the United States, Chap. 18 of Ladd, H. S., ed., Paleoecology : Geol. Soc. America Mem. 67, p. 505-541.

Reeside, J. B., Jr., and Cobban, W. A., 1960, Studies of the Mowry Shale (Cretaceous), and contemporary formations in the United States and Canlada: U.S. Geol. Survey Prof. Paper 355, $126 \mathrm{p}$.

Reeves, Frank, 1927, Geology of the Cat Creek and Devils Basin oil fields and adjacent areas in Montana: U.S. Geol. Survey Bull. 786-B, p. 39-95.

1931, Geology of the Big Snowy Mountains, Mont. : U.S. Geol. Survey Prof. Paper 165-D, p. 135-149.

Richards, P. W., 1955, Geology of the Bighorn Canyon-Hardin area, Montana and Wyoming: U.S. Geol. Survey Bull. 1026, $93 \mathrm{p}$.

- 1957, Geology of the area east and southeast of Livingston, Park County, Montana : U.S. Geol. Survey Bull. 1021-L, p. $385-438$.

Roberts, A. E., 1957, Coal-bearing rocks and mines at Cokedale, Park County, Montana, in Billings Geol. Soc. Guidebook 8th Ann. Field Conf., Crazy Mountains basin, Montana, September 1957 : p. 39-47.

1963, The Livingston Group of south-central Montana: U.S. Geol. Survey Prof. Paper 475-B, p. B86-B92.

1964a, Geology of the Brisbin quadrangle, Montana: U.S. Geol. Survey Geol. Quad. Map GQ-256.

$1964 \mathrm{~b}$, Geology of the Chimney Rock quadrangle, Montana: U.S. Geol. Survey Geol. Quad. Map GQ-257.

1964c, Geology of the Hoppers quadrangle, Montana : U.S. Geol. Survey Geol. Quad. Map GQ-258. 
1964d, Geology of the Livingston quadrangle, Montana : U.S. Geol. Survey Geol. Quad. Map GQ-259.

1964e, Geologic map of the Maxey Ridge quadrangle, Montana: U.S. Geol. Survey Misc. Geol. Inv. Map I-396.

1964f, Geologic map of the Fort Ellis quadrangle, Montana: U.S. Geol. Survey Misc. Geol. Inv. Map I-397.

1964g, Geologic map of the Mystic Lake quadrangle, Montana: U.S. Geol. Survey Misc. Geol. Inv. Map I-398.

1964h, Geologic map of the Bozeman Pass quadrangle, Montana : U.S. Geol. Survey Misc. Geol. Inv. Map I-399.

1965, Correlation of Cretaceous and lower Tertiary rocks near Livingston, Montana, with those in other areas in Montania and Wyoming: U.S. Geol. Survey Prof. Paper 525-B, p. B54-B63.

1966, Geology and coal resources of the Livingston coal fleld, Gallatin and Park Counties, Montana : U.S. Geol. Survey Prof. Paper 526-A, 56 p.

Robinson, C. S., Mapel, W. J., and Bergendahl, M. H., 1964, Stratigraphy and structure of the northern flanks of the Black Hills uplift, Wyoming, Montana, and South Dakota : U.S. Geol. Survey Prof. Paper 404, 134 p.

Robinson, C. S., Mapel, W. J., and Cobban, W. A., 1959, Pierre Shale along western and northern flanks of Black Hills, Wyoming and Montania: Am. Assoc. Petroleum Geologists Bull:, v. 43, no. 1, p. 101-123.

Robinson, G. D., 1961, Origin and development of the Three Forks basin, Montana: Geol. Soc. America Bull., v. 72, no. 7, p. 1003-1014.

1963, Geology of the Three Forks quadrangle, Montana : U.S. Geol. Survey Prof. Paper 370, 143 p.

Robinson, G. D., Klepper, M. R., and Obradovich, J. D., 1969, Overlapping plutonism, volcanism, and tectonism in the Boulder batholith region, western Montana: Geol. Soc. America Mem. 116, p. 557-576.

Robinson, G. D. and Marvin, R. F., 1967, Upper Oretaceous volcanic glass from western Montana : Geol. Soc. America Bull., v. 78, p. 601-608.

Ross, C. P., Andrews, D. A., and Witkind, I. J.,1955, Geologic map of Montana : Washington, U.S. Geol. Survey, scale 1 : 250,000, 2 sheets.

Rubel, D. N., 1964, Geology of the Independence area, Sweetgrass and Park Counties, Mont: Ann Arbor, Michigan Univ., Ph. D. thesis (available on microfilm from University Microfilms, Inc., Ann Arbor, Mich.).

Rubey, W. W., 1929, Origin of the siliceous Mowry Shale of the Black Hills region: U.S. Geol. Survey Prof. Paper 154-D, p. 153-170.

- 1931, Lithologic studies of fine-grained Upper Cretaceous sedimentary rocks of the Black Hills region: U.S. Geol. Survey Prof. Paper 165-A, p. 1-54.

Schmidt, R. G., and Zubovic, Peter, 1961, Cobern Mountain overthrust, Lewis and Clark County, Montana: U.S. Geol. Survey Prof. Paper 424-C, p. C175-C177.

Seager, G. F., 1944, Gold, arsenic, and tungsten deposits of the Jardine-Crevasse Mountain district, Park County. Montana: Montana Bur. Mines and Geology Mem. 23, 111 p.

Simms, F. E., 1966, The igneous petrology, geochemistry, and structural geology of part of the northern Crazy Mountains, Montana : Cincinnati, Ohio, Univ. Cincinnati, Ph. D. thesis (available on microfilm from University Microfilms, Inc., Ann Arbor, Mich.).
Simpson, G. G., 1937, The Fort Union of the Crazy Mountain field, Montana, and its mammalian faunas: U.S. Natl. Mus. Bull. 169, 287 p.

Sims, J. D., 1967, Geology and sedimentology of the Livingston Group, northern Crazy Mountains, Montana: Evanston, Ill., Northwestern Univ., Ph. D. thesis (available on microfilm from University Microflims, Inc., Ann Arbor, Mich.).

Skeels, D. C., 1939, Structural geology of the Trail CreekCanyon Mountain area, Montana: Jour. Geology, v. 47, no. 8, p. 816-840.

Skipp, B. A. L., and Hepp, M. M., 1968, Geologic map of the Hatfield Mountain quadrangle, Gallatin County, Montana : U.S. Geol. 'Survey Geol. Quad. Map GQ-729, scale $1: 24,000$.

Skipp, B. A. L., and Peterson, A. D., 1965, Geologic map of the Maudlow quadrangle, southwestern Montana: U.S. Geol. Survey Misc. Geol. Inv. Map I-452, scale $1: 24,000,2$ sheets.

Slaughter, Maynard, and Earley, J. W., 1965, Mineralogy and geological significance of the Mowry bentonites, Wyoming: Geol. Soc. America Spec. Paper 83, 116 p.

Smedes, H. W., 1966, Geology and igneous petrology of the northern Elkhorn Mountains, Jefferson and Broadwater Counties, Montana : U.S. Geol. Survey Prof. Paper 510, 116 p.

Smith, J. G., 1965, Fundamental transcurrent faulting in northern Rocky Mountains: Am. Assoc. Petroleum Geologists Bull., v. 49, no. 9, p. 1398-1409.

Stanton, T. W., 1903, A new fresh-water molluscan faunule from the Cretaceous of Montana: Am. Philos. Soc. Proc., v. 42 , p. $188-199$.

Stebinger, Eugene, 1914a, Titaniferous magnetite beds on the Blackfeet Indian Reservation, Montana: U.S. Geol. Survey Bull. 540-H, p. 329-337.

1914b, The Montana group of northwestern Montana : U.S. Geol. Survey Prof. Paper 90, p. 61-68.

Stokes, W. L., 1942, Some field observations bearing on the origin of the Morrison gastroliths: Science, v. 95, no. 2453, p. 18-19.

Stoll, W. C., and Armstrong, F. C., 1958, Optical calcite deposits in Park and Sweetgrass Counties, Montana: U.S. Geol. Survey Bull. 1042-M, p. 431-479.

Stone, R. W., 1908, Coal near the Crazy Mountains, Montana, in Part 2, Coal and lignite: U.S. Geol. Survey Bull. 341, p. 78-91.

Stone, R. W., and Calvert, W. R., 1910, Stratigraphic relations of the Livingston Formation of Montana : Econ. Geology, v. 5, no. 6, p. 551-557; no. 7, p. 652-669; and no. 8, p. 741-764.

Stow, M. H., 1938, Dating Cretaceous-Eocene tectonic movements in Bighorn Basin by heavy minerals: Geol. Soc. America Bull., v. 49 p. 731-761. 1946, Dating sedimentation, vulcanism and orogeny in Beartooth Mountain region, Montana, by heavy minerals: Geol. Soc. America Bull., v. 57, p. 675-686.

Tanner, J. J., 1949, Geology of the Castle Mountain area, Montana : Princeton, N.J., Princeton Univ., Ph. D. thesis (available on microfllm from University Microfilms, Inc., Ann Arbor, Mich.).

Tappe, John, 1966, The chemistry, petrology, and structure of the Big Timber igneous complex, Crazy Mountains, Montana: Cincinnati, Ohio, Univ. Cincinnati, $\mathrm{Ph}$. D. thesis (available on microfilm from University Microfllms, Inc., Ann Arbor, Mich.).

Thom, W. T., Jr., 1922, Oil and gas prospects in and near the Crow Indian Reservation, Montana : U.S. Geol. Survey Bull. 736-B, p. 35-53. 
Thom, W. T., Jr., Hall, G. M., Wegemann, C. H., and Moulton, G. F., 1935, Geology of Big Horn County and the Crow Indian Reservation, Montana: U.S. Geol. Survey Bull, 856, $200 \mathrm{p}$.

Thompson, R. M., Love, J. D., and Tourtelot, H. A., 1949, Stratigraphic sections of pre-Cody Upper Cretaceous rocks in central Wyoming: U.S. Geol. Survey Oil and Gas Inv. Prelim. Chart 36, vertical scale, 1 inch to 200 feet $(1: 2,400)$, 2 sheets.

Tilling, R. I., Klepper, M. R., and Obradovich, J. D., 1968, K-Ar ages and time span of emplacement of the Boulder batholith Montana : Am. Jour. Sci., v. 266, p. 671-689.

Tschudy, R. H., and Veach, S. D., 1965, Plant and miscellaneous microfossils from the Thermopolis and Mowry Shales: U.S. Geol. Survey open-file rept., $6 \mathrm{p}$.

Van Houten, F. B., 1962, Frontier Formation, Bighorn Basin, Wyoming, in Symposium on Early Cretaceous rocks of Wyomining and adjacent areas, Wyoming Geol. Assoc., 17th annual field conference, 1962 : Casper, Wyo., Petroleum Information, p. 221-231.

Vhay, J. S., 1934, The geology of a part of the Beartooth Mountain front near Nye, Montana: Princeton, N.J., Princeton Univ., Ph. D. thesis (aivailable on microfllm from University Microfllms, Inc., Ann Arbor, Mich.).

1939, Some features of the Livingston Formation near Nye, Montana: Am. Geophys. Union Trans., 20th Ann. Mtg., pt. 3, p. 433-437.

Viele, G. W., and Harris, F. G., 3d, 1965, Montana Group stratigraphy, Lewis and Clark County, Montana: Am. Assoc., Petroleum Geologists Bull., v. 49, p. 379-417.

Waagê, K. M., 1955, Dakota Group in northern Front Range foothills, Colorado: U.S. Geol. Survey Prof. Paper 274-B, p. 15-51.

1959, Stratigraphy of the Inyan Kara Group in the Black Hills : U.S. Geol. Survey Bull. 1081-B, p. 11-90.

Washburne, C. W., 1908, Gas fields of the Bighorn Basin, Wyoming: U.S. Geol. Survey Bull. 340-F, p. 348-363.
Weed, W. H.; 1893, The Laramie and the overlying Livingston Formation in Montana : U.S. Geol. Survey Bull. 105, 68 p.

1899a, Description of the Fort Benton quadrangle, [Montana] : U.S. Geol. Survey Geol. Atlas, Folio 55, 9 p.

$1899 \mathrm{~b}$, description of the Little Belt Mountains quadrangle, [Montana] : U.S. Geol. Survey Geol. Atlas, Folio 56, $11 \mathrm{p}$.

Weimer, R. J., and Hoyt, J. H., 1964, Burrows of Callianassa major Say, geologic indicators of littoral and shallow neritic environments: Jour. Pàleontology, v. 38, No. 4, p. 761-767.

Wentworth, C. K., and Williams Howel, 1932, The classification and terminology of the pyroclastic rocks: Natl. Research Council Bull. 89, p. 19-53.

Williams, Howel, Turner, F. J., and Gilbert, C. M., 1954, Petrography-An introduction to the study of rocks in thin sections: San Francisco, W. H. Freeman and Co., 406 p.

Wilson, C. W., Jr., 1934, Geology of the thrust fault near Gardiner, Montana : Jour. Geology, v. 42, no. 6, 649-663.

1936, Geology of the Nye-Bowler lineament, Stillwater and Carbon Counties, Montana : Am. Assoc. Petroleum Geologists Bull., v. 20, no. 9, p. 1161-1188.

Wolff, J. E., 1938, Igneous rocks of the Crazy Mountains, Montana : Geol. Soc. America Bull., v. 49, p. 1569-1626.

Wood, H. E., 2d, chm., and others, 1941, Nomenclature and correlation of the North American continental Tertiary : Geol. Soc. America Bull., v. 52, no. 1, p. 1-48.

Yen, T. C., 1951, Fresh-water mollusks of Cretaceous age from Montana and Wyoming: U.S. Geol. Survey Prof. Paper 233-A pt. 1, p. 1-9.

Young, Keith, 1951, Foraminifera and stratigraphy of the Frontier Formation (Upper Cretaceous), southern Montana : Jour. Paleontology, v. 25, no. 1, p. 35-68.

Zapp, A. D., and Cobban, W. A., 1960, Some late Cretaceous strand lines in northwestern Colorado and northeastern Utah: U.S. Geol. Survey Prof. Paper 400-B, p. B246-B249. 


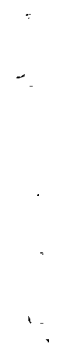




\section{INDEX}

[Italic page numbers indicate major references]

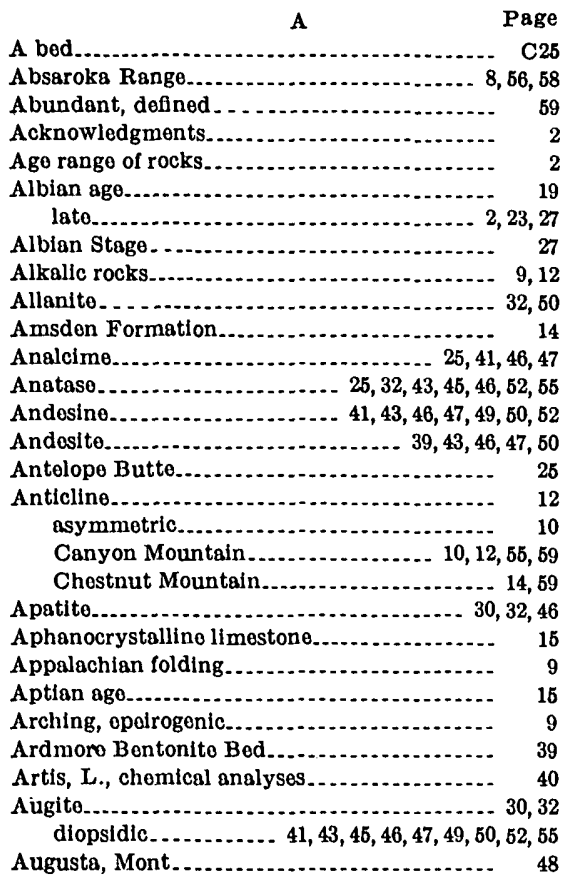

Basin, Wyo...

Batholith, Boulder

Idaho...

Battle Ridge.

Beach deposit, regressive....................

Bear Formation.

Bearpaw Formation

Bearpaw Shale........................ 8, 36, 39,47,48

Beartooth Range................. 2, 5, 9, 10, 14, 65, 56

Beartooth uplift............................. 9,10

Bedding, ropeated reverse graded

Bedding-plane faults.

Belle Fourche quadrangle.

Belly Rivor Formation.

Belt doposits.

Belt Suporgroup, LaHood Formation.......

Benton age.

Benton Group, Graneros Shale............. 19

Bonton Shalo.................................. 16

Bentonito........... 8, 15, 17, 23, 25, 26, 27, 36, 41, 42, 46

Bibliography ................................ 109

Big Belt Mountains.

Big Bolt uplift.

Big Couleo-Hailstono structure.

Big Elk domo...............................

Big Elk Sandstono Momber, thickness.........

Big Timber, Mont............................ 40

Bighorn Basin...... 9,10,13,14,15,16,18, 24, 28, 29, 55

Bighorn Mountains........................... 15, 19

Bllings. Mont.

29

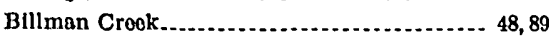

Page

Billman Creek Formation ......... C4, 8, 24, 36, 48, 89 age and correlation...................... 49 lithologic composition................... 48 type section. ........................... 89 Biotite:..... 18, 25, 28, 30, 32, 41, 43, 45, 46, 47, 49, 50, 52 bronze....................................... 41,47 Birdhead Sandstone Member................. 18

Black Hills, S. Dak........................... 19 Wyo ....................... 21, 23

Black Hills area, Wyoming.................. 4, 5, 18

Blackleaf Formation, Bootlegger Member..... Flood Member.

Taft Hill Member.........................

Vaughn Member........................

Blair Formation

Bolson deposits.

(1)

Botts, S., chemical analyses. ................. 40

Boulder, Mont

Boulder bátholith ............................ 10,41

Boulder River Sandstone Member.... 5, 24, 25, 26, 27 thickness

Boulder River valley .......................... 24

Bozemsn, Mont ......................... 12, 15, 50

Bozeman coal field.

Bozeman Pass............ 34

Brackett Creek............................... 54

Brackish-water deposit.............. 17, 26, 50, 54,65

Breccia, early acid........................ 56, 57

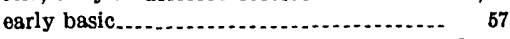

Bridger, Mont................................ 24, 27

Bridger Range......... 2, 5, 9, 10, 16, 31, 34, 36, 40, 52, 54

Bridger uplift.................................. 9,51

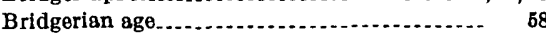

Brookite......................................... 32

Buffalo, Wyo................................... 19, 23

Buffalo-Lake De Smet area, Wyoming........ 16

Butte Quartz Monzonite....................... 46

C

C bed........................... 25 Calc-alkalic rocks.................... 9,12

Calcite cementing agent................. 41, 43, 46, 49, 52 dikes.-

Cambrian age, Middle...................... 2

Campanian rocks, upper.............. 48

Campanian time.

late

Canyon Mountain .......... 14, 17, 23, 61, 65, 67, 68, 70 Canyon Mountain anticline............. 10, 12, 55, 59 Carlile age, late......................... 26 Carlile Formation. ......................... 16

Carlile Shale . ......................... 5, 27, 28

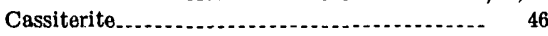

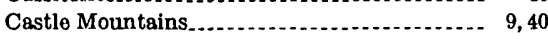

Cathedral Cliffs Formation................... 4,56

Cenomanian rocks........................ 5, 26

Cenozolc rocks. . .

Chadwick, R. A., cited.................. 12, 56

Chert................................. 5, 26, 28, 50

Chestnut Mountain anticline.......... 14, 59

Chimney Rock, Mont..................... 8,55
Page

Chimney Rock quadrangle................. C25

Chloe, G., chemical analyses . ................ 40

Chlorite...................... 32, 41, 46, 48, 49, 50, 52

Chouteau County.......................... 31

Claggett Formation . . . . . . .

Claggett Shale..................... 8, 31, 36, 39, 42, 45

Clarks Fork area.......................... 56

Clay minerals.

Clinoptilolite............................ 41,47

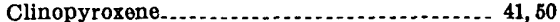

Cloverly conglomerate....................... 13

unconformity .............................. 13

Cloverly Formation .................. 4, 13, 15, 16, 18

Pryor Conglomerate Member............. 13

Clyde Park, Mont............................ 54

Coal............. 5, 8, 13, 23, 24, 26, 30,31, 32, 34, 35, 36

A bituminous ............... 32

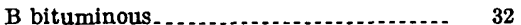

C bituminous. .

coking quality ........................... 32

lignite-noncoking

lignitic.................................... 34

reserves. . . . .

Coal-bearing swamps, Morrison............... 14

Cobban, W. A., cited .................. 4, 29, 30, 34, 48 fossil identification.................. $28,29,34,47$

Cody, wyo............................... 27

Cody Shale_....................... 5, 24, 27, 29, 30,68

age and correlation...................... 28

composite section................................ 68

Eldridge Creek Member................... 4, 5

thickness

lithologic composition.

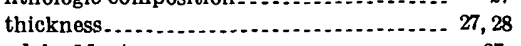
Cokedale, Mont $29, \ldots, 36,41,42,70,71,77,84,89,95,97$, Cokedale Formation.... 4, 8, 24, 31, 36, 39, 41, 42, 55, 77 age and correlation . -

lithologic composition

thickness...

type section.

Cokedale No. 3 coal bed........................ 34

Colgate Member

Colorado Formation......................... 16, 24

Colorado Group........................... 16, 21

Colorado Shale............................ 16, 19, 24

Big Elk Sandstone Member, thickness.... 27

Colorado Springs, Colo........................ 13

Columbus, Mont. .................. 24, 31, 39, 46, 48

Common, defined ......................... 59

Concretions, calcareous.................... 49, 50

Cone Calcareous Member.................. 28

Conglomerate................................ 34

Coniacian age ..... 26, 29

Coniacian Stage............. 9

Copper mineral $\ldots \ldots \ldots \ldots . . .43,45,46,47,49,50,52,55$

Coquina.................................... 15

Cordilleran miogeosyncline................. 2

Corundum . ......... 25, 36, 41, 43, 45, 46, 47, 49, 50, 52 colorless................................... 32

Crandall Conglomerate..................... 8,9,56

thickness ..

Crazy Mountains................. 9, 12,48, 53, 54, 55 


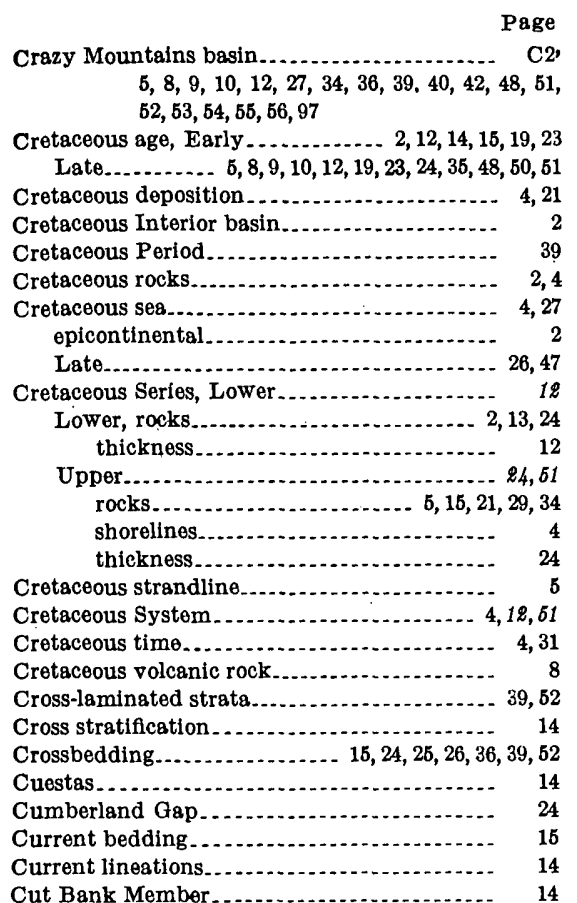

\section{D}

Dakota Group of Colorado.

Dakota Sandstone

Deerfield Oil Corp. Strong 1 well............ 68

Deltaic deposition

Devils Tower.................................. 18

Dikes.

calcite.

Diopsidic augite........ 41, 43, 45, 46, 47, 49, 50, 52, 55

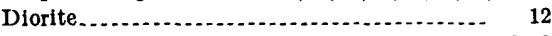

Disconformity ............................. 16, 18 transgressive .......................... 18

Dome, Big Elk. .......... 27

\section{$\mathbf{E}$}

Eagle Creek ....... 31

Eagle Formation.

Eagle Sandstone....... 4, 10, 24, 30, 35, 36, 42, 43, 55, 71

age and correlation..................... composite section........................ 76

lithologic composition. . ................... reference section......................... $\quad 71$

thickness

Virgelle Sandstone Member...... 5, 9, 16, 25, 29, 30

Eagle sea.

Eagle time, early

late................ 9

Eldridge Creek

Eldridge Creek Member. . . . . . . . . . . . . 4, 5, 27, 29

thickness............................... 28

Elk Basin, Wyo ........................... 30

Elk Basin Sandstone Member.

Elkhorn Mountains.................. 5, 8, 9, 30, 31, 40

Elkhorn Mountains Volcanics.... $9,10,39,40,43,46,48,65$

Ellis sea.

Elmore, P., chemical analyses............. $9,10,12$

Emigrant Peak ares.................

En echelon faults........................... 9,10

En echelon folds........................... 9,10

Eocene age ................................. 2, 12

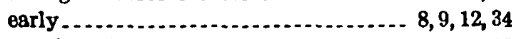

Eocene deposits.

\section{Eocene Series thickness. \\ Epeirogenic arching. \\ Epeirogenic uplift, post-Laramide Epidote. . ............ 25, 32, 43, 45, 46, 47, 49, 50, 52 \\ F}

Fall River Formation.

Fault, Emigrant

Pass..

(10

ault zone, Lake Basin transcurrent.

Faulting, thrust............................. 12

Faults, bedding-plane

en echelon ................................. 9,10

high-angle reverse....................... 10

low-angle thrust.......................... 10

normal ................................ 12

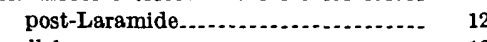

parallel.

thrust

Feldspar, potassium $\ldots \ldots \ldots \ldots \ldots \ldots \ldots . .41,43,46,47$

First Cat Creek Sand . ....................... 18

Fleshman Creek syncline..................... 41

Flood Member................................ 4

Flood-plain deposits..... 51

Flute casts . ................................ 18

Fluvial deposits............................ 8,15

Folding

Appalachian.

asymmetrical

symmetrical ............................ 9

synclinal . .

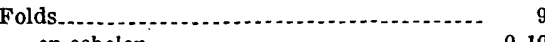

en echelon

Foreset beds.............................. 39

Fort Union Formation.... 4, 5, 10, 31, 39, 41, 51, 55, 97 age and correlation....

Lebo Andesitic Member.

lithologic composition....................

lower conglomeratic sandstone member

middle sandstone and mudstone member

reference section

thickness.

upper conglomeratic sandstone member.

Fort Union time

Fossil localities, Mesozoic:

D

$28,58,69$

D1282

D1283 .

D1779 189

D2592 . . .

D3082................................ 47

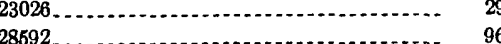

$28592 \ldots 3 . \ldots 6 n$

28594 .

Fossil localities, Paleobotany:

D1610.................. 81

D1611 . . . 81

D1612 ........... 48,86

D1613 .................................... 48, 84

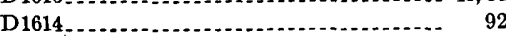

D1782

D1783

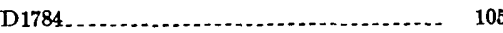

D1785 ...

D1815-1 . .

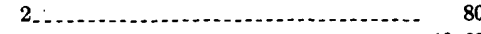

D3512-A ............... 19,63

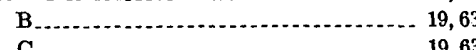

D

F

G.

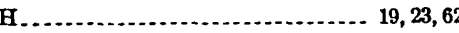

\begin{tabular}{ll} 
I & 62 \\
\hline
\end{tabular}
Fossil localities, Paleobotany-Con. Page

62
$M$

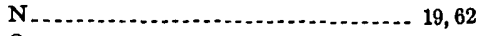

0

T

U.

D3513-A ............................. 66

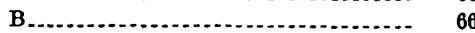

D3842-A.................................. 19, 23, 65

B................................. 19, 23, 65

C..................................... 64

D3843-A.................... 67

B

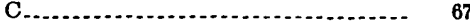

D................................ 67

E

4104-A

B......

C........... 95

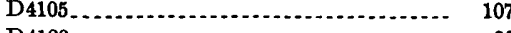

D4120

Fossils:

Abietineaepollenites................ 20,21, 22,37, 38

Acanthoceras amphibolum................. 6

Acanthotriletes............................ 21, 22

Aclistochara mundula................... 15

Actaeon propinquus....................... 28

Actinocamax sp......................... 28, 29

Aequitriradites......................... 20, 21, 37

Alga-dinoflagellate...................... 20, 21, 22

Alga-hystrichosphere................... 20, 21, 22

Alga-Lecaniella

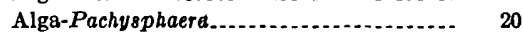

Alga-Pterospermopsis..................... 22

Alga-Schizocystía.......................... 22

Alga-Tetraporina....................... 22

Algae, fresh-water........................ 16

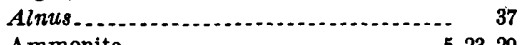

Anemia

$\begin{array}{lr}\text { Anemia } & 19 \\ \text { Angiosperm tricolpate pollen. }\end{array}$

Anisomyon sp............................. 29

Anomia subquadrata....................... 28, 29

sp................................... 34

Appendicisporites................. 19, 20, 21, 34, 37

Applanopsis.............................. 20, 22

Aquilapollenites attenuatus................. 48 calvers.

polaris.

reticulatus.

48

Atopochara trivolvis

Baculatisporites

Baculites asper............................. 28, 29

asperiformis

baculus..

clinolobatur

codyensis.............................. 29

compressus....................... 6, $39,47,48$

cuneatus $6,39,48$

eliasi 6

gilberti.

grandis....

gregoryensis

jenseni.

mclearni.............. 6

perplexus......................... 6

reesidei.................................... 6,48

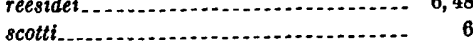

sp

Betula.................................. 38, 89

Biretisporites............................. 21

Bisaccate pollen............................ 26

Botryococcus............................ 16 
Fosslls-Continued

Brachiopods

Page

Barrorings,

Callianassa major

Callista sp................................. 47

Calycoceras sp.............................. 6

Carva ................................... 38

Cephalopods........................ 28, 29, 30, 47

Charophytes........................... 15

Cingulatisporites.........

Clams, fresh-water......................... 50

Classopollis.......................20, 22, 28, 37, 50

Clavator harisi _............................ 15

Clioscaphites choteauensis.................. 6, 29 saxitonianus........................... 6 vermiformis............................ 6, 29

Coahullites.

Collignoniceras hyatti....................... 6 woolloari...

Concaotsporites........

Concavissimisporites

Condylarth, Jaw and teeth ............... ob

Crassatella andrewsi........................ 29

wyomingensis......................... 29

sp.................................. 28, 34

Crassostrea soleniscus.................... 34

Crenella.sp............................. 47

Cupanetdites......................... 37, 39

Cyathidites_L....................... 20, 21, 22, 38

Cumbophora arenaria....................... 34

Cypridea anomala.......................... 16

Decussosporites...................... 20, 21, 22,37

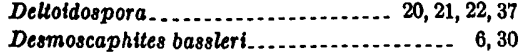

erdimanni-.......................... B

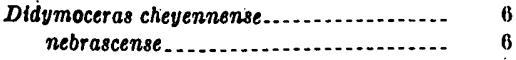
stevensoni.

Dinoflagellates__. $23,26,38,50,54$

Dinosaur bones................. 15, 36, 43, 50, 54

Discoscaphites nebrascensis................ 6

Dunveganoceras albertense................. 6

pondi............................... 6

$\begin{array}{ll}\text { Echidnocephalus sp........................... } & 29 \\ \text { Engelhdrdtioldites } & \end{array}$

Engelhdrdtioidites........................... 34,37

Erdtmannipollis........................... 38, 39

Ericipites.............................. 38

Eucommidittes................... 20, 21, 22, 26, 34, 37

Eutrephoceras sp........................ 29

Exiteloceras jenneyi.........................
Exogura sp...

Exogura sp.............................. 28, 29

Fauna, Eagle........................... 30

fluvlatile $\ldots$

$\begin{array}{ll}\text { fresh-water invertebrate................. } & 54 \\ \text { marine. } & 19\end{array}$

marine............................. 19

shallow-water.....................

Fern spores, monolete..................... 26

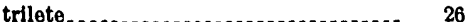

Fish, bones............................. 15

scales.............................. 23, 29

Gastroliths............................. 16

Gastropods............................. 28; 29

fresh-water_....................... 15, 36, 49

Ghoshispora............................ 37, 54

Gleichenitdites................... 20, 22, 34, 37, 38

Grvphaea sp............................. 28

Gyrodes conradi......................... 29

depressa............................. 28

sp................................... 29

Hamulatisporis.................... 20, 22, 37,38

Hemitelia............................... $3^{7}$

Hoploscaphites nicolletii................... 6

Hystrichospheres................. 23, 26, 38, 50, 54

Ichthyodectes sp....................... 29

Inaperturopollenites................ 20, 22, 34, 37, 38
Fossils-Continued Page

Inoceramus brown

comancheanus -

deformis................................ 6

erectus.............................. 6

involutus.............................. 28, 29

labiatus............................ 6

problematicus............................ 6

stantoni.......................... 28

sp........................... 26, 29, 32, 34

Klukisporites

Kurtzipites................................. 38

Laevigatosporites............................ 37, 38

Leaf, debris................................ 36

impressions............................. 43

Leaves ................................. 32, 34, 45

Lecaniella............................... 21

Legumen sp........ 28

Lingula subspatulata ....................... $\quad 29$

Lioplacodes tenuicarinata ................... 45, 60

Lioplacodes sp......................... 51,55

Lycopodiumsporites................. 20, 21, 22, 38

Mactra alta

Mammals, Paleocene.

Tertlary-type.

Metacupris an

Micrhystridium.............................

Microfoveolatisporis........................ 34

Microreticulatisporites _.............. 38

Mollusks, fresh-water_............ 15, 43, 49, 50, 55

Momipites.

Monoclonius sp

Monolete fern spores.

Monosulcate pollen .................... 19, 23, 26

Monosulcites.........................20, 21, 22, 37

Neogastroplites americanus _............... 7 cornutus............................ hassi................................... 7 maclearni........................... 7,27

muelleri

Nucula coloradoensis................... 29

Operculites.

Ophiomorpha

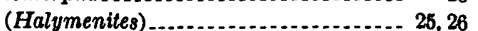

Osmundacidites............................. 20

Ostracodes............................... 15

steinkerns

Ostrea coalvillensis....................... 34

congesta............................. 28, 29

russelli............................. 47

sp.................................. 29, 34

Ovodites..................................... 22

Oysters...................................... 29, 32

Paliurus........................... 38

Palynomorphs................... 26, 45, 49, 50, 64

Panope sp.................................... 28, 47

Parvisaccites............................... 20

Pelecypods........................ 15, 28, 29, 47 fresh-water.......................... 36

Pholadomya papyracea..................... 28, 29

Physa ................................. 45 sp.................................... 50

Pilosisporites............................... 21

Pinna sp............................... 28, 29

Placenticeras meeki............ 47

Plants, fragments.................. $5,18,23,32,49$ impressions............................ 15 microfossils................. 4, 8, 19, 48, 50,54

Plesiacanthoceras wyomingense.

Plicatella.............................. 20, 21

Pollen................... 5, 26, 36, 43, 45, 48, 51, 57 bisaccate........................... 26 monosulcate....................... 19, 23, 26

taxodiaceous........................... 28

tricolpate....

anglosperm....................... 19

triporate..

Polycolpites.

Polypodiacidites.
Fossils-Continued Page

Polypoditsporites............................ 637

Prionocyclus royomingensts.................. 6

Proteacidites _............................ 34, 37, 38

Protelliptio douglassi..................... 4,7, 18

Pteria linguaeformits........................... 29, 47

nebrascana........................... 47

sp.................................. 28

Pterospermopsis............................ 23; 26

Rhabdotophorus aldrichi.................. 50,81

Rugubivesiculites .......................... 20, 22

Scaphites binneyi......................... 29

corvensis.

depressus........................ 5, 6, 29

ferronensis........................... 6

hippocrepis.......................... 6, 30

nipricollensis......................... 6

preventricosis

tetonensis........................... 29

ventricosus........................... 6

warreni................................ 6

sp ................................ 28

Schizosporus............................. 22, 38

complexus.......................... 54

Sciponoceras graclle..................... 6

Serpula sp............................. 47

Snalls, fresh-water................ 15, 45, 50, 61

Sphaerium.............................. 50

Sphenodiscus............................. 6

Spores................ 5, 19, 26, 36, 43, 45, 48, 51, 67 monolete fern........................ 26 trilete fern............................ 26

Stereisporites _...................... 20, 34, 37, 38

Tancredia americana...................... 47

Taurocuspor ites.

Taxodiaceous pollen.

Tellina sp.

Tessarolax hitzii.............................. 29

Tetraclaeonodon symbolicus.................. 56

Tetrapollis...................................

Todisporites.

Trails, marine bottom-dwelling organisms.............................. 17, 18

worm -......... 18

Triatriopollenites.......................... 37,38

Triceratops................................ 6

Tricolpate pollen........................... 26 angiosperm................ 19

Tricolpites................................ 39 interangulus........................... 54

Tricolpopollenites................ 20, 21, 22, 37; 38

Tricolporites.............................. 37, 38

Trilete fern spores......................... 28

Trilobosporites........................... 19, 21

Triplanosporites........................... 38

Triporate pollen............................ 28

Trivestibulopollenites......................... 37

Turritella sp.............................. 28, 29

Turtle bones............................. 15

Ulmipollenites............................... 38, 39

Unio reesideanus.

Unionidae.................................... 50,55

Verrucosisporites......................... 21, 37, 38

Vertebrates............................... 50

Vitreisporites...................... 20, 21, 22, 37, 50

Viviparus.................................... 45 meeki................................ 51, 65

sp.................................. 50

Wood, debris.............................. 36

petrified............................. 43

Worm tralls.................................. 18, 47

Fox Hills Sandstone..................... 27, 34, 35

Colgate Member .......................... 36, 49

Fractures, tension............................. 12

Frasert; Q. D., clted...........................

Fretwork.................................... 17

Fridley Peak quadrangle.................... b7

Front Range................................. 18 


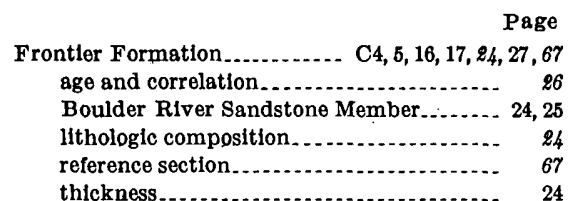
G

Gallatin County $\ldots . .25$ Gallatin Range... 2, 8, 10,12, 14, 15, 16, 18, 24, 55, 56, 57
Gallatin River valley Gallatin Valley ............................... 51 Gannett Group . ........................... 15 Gantnier, R. F., sandstone analyses. ........ 19,42 Gardiner, Mont . . . . ................. 24, 29, 31, 34, 41 Gardner River- 34 Garnet ........ 25, 30, 36, 41, 43, 45, 46, 47, 49, 50, 52, 55 colorless. $25,30,36,41,43,45,46,47,49,50,52,55$ Garnet Mountain area................... 12,57 Gazin, C. L., fossil identification Geologic setting............................. \& Gill, J. R., cited $\ldots \ldots \ldots \ldots . .4,46,48$ Glacial deposits ........................... 8 Glacier National Park Glauconite..................... 4, $5,18,23,24,26,28$ Glendive, Mont. . . .............................. 36, 49 Golmeyer Creek Volcanics................... 4, 56, 57

Grain size, coarse, defined................ 58 flne, defined................................. 58 granule, defined.

medium, defined.

very coarse, defined ...... 58

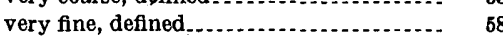

Graneros Shale............................. 19, 2

Gravel, lag.............. 15

Great Falls, Mont. ............... 13, 23, 28

Great Falls, Mont., unconformity near.......

Great Plains................................ $\quad 39$

Greenhorn age

Greenhorn Calcareous Member.............. 28

Greenhorn Formation...................... 28

Greybull Sandstone Member.............. 4, 16, 18

Groove casts............................ 18

\section{H}

Hardin, Mont Harlowton, Mont............ 15, 18, 27, 54 Heart Mountain, Wyo...................... 54 Hell Creek Formation........... 8, 34, 36, 48, 50, 51, 54 Hell Creek time. ................ 40 Hematite Heulandite ........................ 41, 43, 46, 47, 49, 50

High-angle reverse foults.

Hilderbrand, F、 A., cited.................... 41

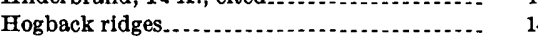

Holocene time................................ 12

Hoppers Formation ............ 4, 8, 24, 36, 48, 50, 95 age and correlation.................... 60 lithologic composition.

thickness...

type section

Hoppers Siding

Hoppers Station................................ 95, 97

Hornblende . . ........ 25, 30, 41, 43, 46, 47, 49, 50, 52, 55 green................................... 32

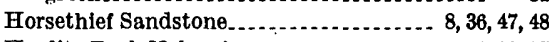
Hyalite Peak Volcanics................ 4, 12, 67 thickness........................... 57 Hypersthene . . ........ 43, 45, 46, 47, 49, 50, 52

$$
\text { I }
$$

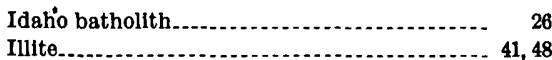

Ilmenite.

$$
\mathrm{J}
$$

Jardine mining district Jefferson Canyon.............................

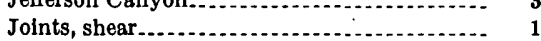

Page

Judith River Formation... C8, 34, 36, 39, 40, 45, 48, 54 Jurassic age................................. 2,12 Late....................... 2, 4, 14, 15

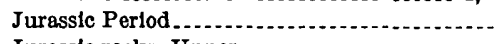

Jurassle rocks, Upper....................... 2,13

\section{$\mathbf{K}$}

Kemmerer, Wyo................... 24 Kootenal Formation............. 2, 4, 12, 16, 17, 18, 59 age and correlation. ..................... 15 composite section........................ 61 Cut Bank Member. lithologic composition. Pryor Conglomerate Member. reference section.......................... 58 Sunburst Sandstone Member............ 14 thickness..

unconformity.

Kyanite.

\section{L}

Labradorite.................... 41, 46, 52

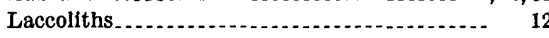

Lacustrine deposits......................... 15, 16

Lag gravel.................. 15

LaHood Formation. 9

Lake Basin fault zone. . . .................... 2,9

Lake Basin lineament. ........................ 9

Lakes, fresh-water.

Lakota Formation....................... 4,14

Laminae, defined........................... $\quad 58$

Lance Formation.......................... 34, 36, 54

Lancían age.

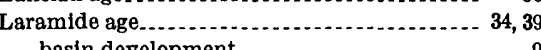

deformation............... 9

intermontane basins.

orogeny ...................... 5,9

structures........ 9

Laramie age................................... 34

Laramle Formation.

Laumontite. . . ................................ 41, 46, 47

Lebo Andesitic Member. .................. 35, 36, 54

Lebo No. 1 unit. ...

Lebo No. 2 unit . ........... 54

Lennep, Mont.......... 39

Lennep Sandstone................. 8, 36, 46, 47, 48

Lenticular beds...................................... 10, 52

Leopold, E. B., fossil identification........... 37

Leucoxene.................. 32, 43, 45, 46, 47, 49, 50, 52

Lewis, G. E. fossil Identification........ 45

Lignite....................... 36

Linley Conglomerate............... 56

Little Belt Mountains. ..................... 2,9

Little Belt uplift. . ...

Livingston, Mont

Livingston cosl field leat beds member........................... 34,45

Livingston Group............. 4, 5, 8, 10, 31, $34,51,55$

Member D . . . . .

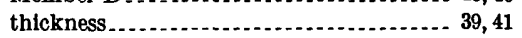

Livingston igneous series. .

Livingston-Shawmut area.................... 27

Location, Livingston area . . . . . . . . . . . . . . . .

Lodgepole Limestone......... 9

Low-angle thrust faults................... 10

Loweth, Mont........................ 31, 46, 47

\section{$\mathbf{M}$}

McGrew, L. W., cited..................... 25

McLeod, Mont........................... 24, 25, 27, 29

McMannis, W. J., cited....................... 12, 46

Madison Group

Madison Range.......................... 8, 34

Maestrichtian time.
Magnetite $\ldots . . . \ldots \ldots \ldots$ C5,

Page $17,18,25,28,30,32,41,43,45,46,47,49,50$, 52 ,

Marlas River Shale......................... 28

Marine deposit . ......................... 16, 26, 65 near-shore, regressive sequence............ 17 transgressive sequence................. 16 offishore.

open water.

23

Maudlow, Mont. .

Maudlow area.............. 8, 34

Maxey Ridge

Maxey Ridge quadrangle.................... 15

Medium bedded, defined $\ldots$

Medium sorted, defined...................... $\quad 58$

Melville, Mont.................. 54

Melville Formation............................ 54

Mesaverde Formation. . . ......... 27

Mesozotc rocks........................... 2, 8, 10, 14 sedimentary .............................. 8

Methods of study ........... 58

Mice................. 5, 18, 23, 25, 26, 28

Miner Creek............................... 46

Miner Creek Formation _. $4,8,24,36,39,41,46,55,84$ lithologic composition.................... 46 Sulphur Flats Sandstone Member. ..... 8, 36, 46

thickness............................... 46 type section.................... 84

Minerals, clay ................................... 32,41 heavy .. $4,5,18,24,25,30,32,36,41,43,46,50,52,55$ nonopaque......................... 55

Miocene tlme.............................. $\quad 12$

Mississipplan age, Early ................ 9

Missour1 River............................... 31

Mitten Black Shale Member................. 45

Montana age................................... 35 early $\ldots . . . . . . . . . .34,36$

Montana Formation....................... 27

Montana Group ......................... 30, 34

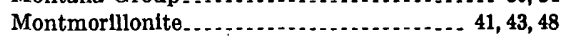

Monument Peak.

Morrison coal-bearing swamps................ 14

Morrison Formation

Mount Everts................................. 28, 31

Mowrle beds............. 19

Mowrle Creek............................. $\quad 19$

Mowry Member............................ 21

Mowry sea................ 2

Mowry Shale ........ 4, 5, 12, 16, 17, 18, 19, 24, 26, 27,65 age and correlation..................... composite section........................ 66 lithologic compositlon. . . reference section........................ 66 thickness

typlcal section............................ 66

Mowry Slliceous Shale Member............. 21

Muddy Sandstone Member.............. 4, 16, 18

Mulr tunnel............................... 34

Muscovite ........... 17, 25, 32, 43, 45, 46, 47, 49, 50, 52

Musselshell River............... 53

Mystic Lake................................... 16

Mystic Lake quadrangle................... 15

\section{$\mathrm{N}$}

Near-shore marlne deposit, regressive sequence.

transgressive sequence....................

Nefsy Shale Member. . . ...................... 21

Newcastle Sandstone..................... 5,18

Niobrara age...............

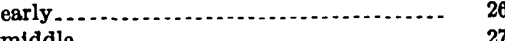

middle

Niobrara Formation.................

Smoky Hill Chalk Member............... 29

Niobrara Limestone....................... 16

Nlobrara Shale. . . . . . . . . . . . . . . . . . . . . 30

Nontronite............................ 41, 49, 50, 52 
Page

Normal faults

C12

post-Laramide.......................... 12

Northern Transcontinental Survey............

Nye, Mont .............................. 14, 40

Nye-Bowler lineament.

Obradovich, J. D., cited

Offshoro marine deposit.

Oligoclase.

Organic material . ........................... 23

Orthoclase...................... 41, 43, 46, 49, 50,52

Palo Beds....

Psleoceno Serles . .

Paleocene strats .............................. 2

Paleocone timo............. 5, 10, 12, 31, 35, 51, 54, 55

Paleozolc rocks............................ 2, 8, 10 upper.

Paradise Valley.

Parallel faults.

Park City, Mont.

(1)

Parkman Sandstone....................... 43

Pass fault.....................................

Peay Sandstone

Peay Sandstone Member..................... 27

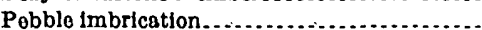

Peterson Limestone...

Pierro Shale................... 27,48 Mitten Black Shalo Member............. 45 Sharon Springs Member, Árdmore Bentonito Bed....................... 39

Plàgloclaso feldspar...........41,43,46,47, 49, 50, 52 oscillation-zoned crystals.................. 46

Platy, definod............................... 58

Plelstocene deposits.......................... 8

Plentiful, defined..

Poorly sorted, defined.

Porcelanite beds, absence of

Porcelanitic sandston

Post-Albian age..............................

Post-Eocenè deposits...........................

Post-Fort Union time.

Post-Laramide epeirogenic uplift.............. 12

Post-Laramido normal faults ....................

Post-Paleocene time.

Pre-Elkhorn Mountains Volcanics............ 41

Pro-Wasatch time............................. 10

Precambrlan rocks....................... 2, 8, 10,55

Precambrian structural features. .............

Pryor Conglomerate Member............ 4, 12, 14, 15 lithologic composition. ................... 14 Montana................................ 13

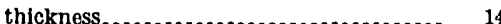

Wyoming .............................. 13

Pryor Mountains.................... 9, 14, 23, 28

Pryor uplift................................ 2,9

Pyrite................... 5, 18, 23, 26, 28, 32, 43, 46, 47

Q

Quadrant Formation..................... 14 Quartz................................. 41,43,47, 49, 50 undulose extinction................... 50,52

Quartzite................................ 50

Quaternary deposits....................... $\quad 30$

$\mathbf{R}$

Radiometric studies

Rare, defined.

Red Lodge, Mont

Reaso Formation

Regressive sequence, near-shore marine deposit.
Ringling, Mont_.................. Ripple marks.............................. 14, 18, 25

Rock Springs region, Wyoming............... 45

Rocks, alkalic............................. 9,12 calc-alkalic. . . . . . . .

Cretaceous Series, Lower................. 2,13

Upper............. 5

Jurassic, Upper........................... 2, 2,13

Mesozoic.............................. 2, 8, 10,14

Paleozolc.............................. 2, 8, 10

upper

. 14

Precambrian........... 2, 8, 10

Rocky Creek Canyon.

Rusty beds............................. 4, 16, 18

Rutile................................. $32,46,47,52,55$

$\mathbf{S}$

St. Mary River Formation................ 48

Sampling methods......................... 58

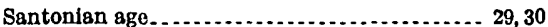

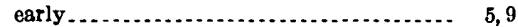

late.................................... 9

Schultz, L. G., cited.......................... 48

rock sampling............ 40

Scour-and-fill structures........... 14, 15, 36, 43, 52, 56

Sentinel Butte Member....................... 54

Sericite....................................... 49

Sharon Springs Member................... $\quad 39$

Shawmut structure.......................... 9

Shear ioints . ................................ 12

Shorelines, Cretaceous Series, Upper........ 4

Shoshone River.............................. $\quad 27$

Shotgun Butte area, Wyoming................ 16

Silica............................ 41, 43,46, 47,49, 52

Sillimanite................. 25, 36, 41, 43, 45, 46, 47, 55

Sills...................................... 12

Skipp, B. A. ,cited........................ $\quad 46$

Skull Creek sea.

$4,18,19,23$

Skull Creek Shale........................ 4, 18, 19, 29

Smedes, H. W., cited................ 56

Smith, H., chemical analyses................ 40

Smoky Hill Chalk Member.................... 29

Sohn, I. G., cited........................... 15

Sole marks................................ 18

Sphene..................... 25, 43, 45, 46, 47, 49, 50, 52

Sphinx Mountain........................... 34

Staurolite . . . .. 25, 32, 36, 41, 43, 45, 46, 47, 49, 50, 52, 55

Stocks................................... 12

Stratigraphic sections....................... 58

measurement of...................... 58

selection of

Stratigraphic summary..

Structural features, Big Coulee-Hailstone.

Sulphur Flats Sandstone Member....... 8, 36, 41, 46 ge and correlation Sunburst Sandstone Member ........... 14 Swamps, Morrison coal-bearing................ Sweetgrass arch ............................... 14

Synclinal folding. . . . . .

\section{$\mathbf{T}$}

Taft Hill Member......................... 4 Taylor, D. W. , fossil identification...... 45, 50, 51, 55 Telegraph Creek................... 29 Telegraph Croek Formation....... 4 ,
$5,16,24,27,28,29,31,34,70$ age and correlation. ................... $\$ 0,35$ composite section......................... 70 lithologic composition................... $\$$ thickness.

Tension fractures.......................... 12

Terrestrial deposits.......................... 15

Tertiary age............................. 2, 12, 64 early .
Page

Tertiary rocks, lower ....................... C2,

lower, volcanic: . . .

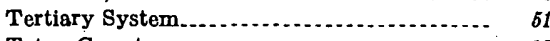

Teton County.................. 15

Thermopolis, Wyo.......................... 16, 23

Thermopolis sea $\ldots$

Thermopolis Shale............ 5, 12, 13, 16, 23, 30,61 age and correlation..................... 18 composite section......................... 64

Greybull Sandstone Member. ............ 4, 16, 18

lithologic composition................... 17

lower sandstone member . . . .......... 4, 16, 18

middle shale member................... . 4, 16, 18

reference section......................... 61

Rusty beds............................ 4, 16, 18

thickness................................ 15

upper sandstone member............... 4, 16, 18

Thick bedded, defined...................... 58

Thickness of rocks............................ 2

Thin bedded, defined

Third Cat Creek Sand...................... 14

Three Forks, Mont. ............... 34

Thrust faulting............................. 12

Thrust faults.......................... 10

Tombstone Sandstone............. 5,29

Tongue River Member..................... 54

Topaz ............................. 25, 45, 46, 47, 52

Torchlight Sandstone... .................... 24

Torchlight Sandstone Member............... 27

Tourmsline............. 25, 30,32, 43, 45, 46, 47, 52, 55

Transcurrent fault zone.......................

Transgressive disconformity .................. 18

Transgressive sequence................... 16, 27

near-shore marine deposit ................ $\quad 16$

Trinity Group.

Tschudy, R. H., cited... 16, 19, 23, 34, 45, 49, 50, 54, 57 fossil identificstion . . . . .......... 20, 22, 26, 34, 37

Tuff microlitic.............. 31

water-laid.

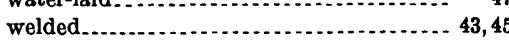

Tullock Formation....................... 54

Two Medicine Formation . . .............. 8, 36, 45

\section{U}

Unconformity, at base of Cloverly conglomerate $\ldots . . . . . . . . . . . . . . . . . . . .$. at base of Kootenai Formation, Livingston, Mont ................................. near Great Falls, Mont. .................

Uplift, Beartooth........................... 9,10

Big Belt............................... 9

Bridger............................... 9,10

epeirogenic, post-Laramide.............. 12

Little Belt..................................

Pryor

V

Vaughn Member......................... 5

Vermiculite................. 41, 48

Very abundant, defined...................... 59

Very rare, defined........................ 59

Very thin bedded, defined................... 58

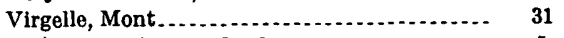

Virgelle Sandstone Member $-{ }_{9}, 16,25,29,30,31,32,35$

Volcanic agglomerate............. 34, 40

Volcanic rock, Cretaceous.............. 8

Tertiary, lower......................... 8

Volcanic sediment......................... 15

Volcanism.................................. 4, 26

$\mathbf{W}$

Wade, Mont ............................ 28

Wasatchian provinclal age.................. 12, 57

Wasatchian rocks, lower.................. 55 
INDEX

Wasatchian tilting
Well sorted, defined
Whitneyite....
Willow Creek
Wilsall, Mont
Wind polishing
Wind River Basin, Wyo. 58

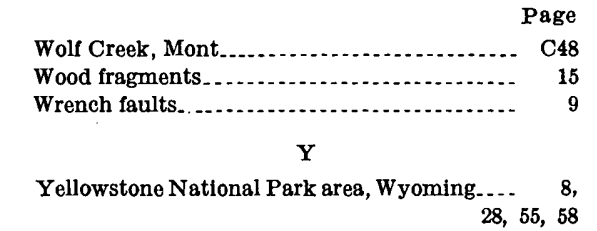

Yellowstone River.

Page $\mathrm{C} 2,34,71$

$\mathbf{Z}$

Zeolite...

.

$25,30,32,43,45,46,47,49,50,52,55$ 